EUGÊNIO JOSÉ SILVA BITTI

FATORES DETERMINANTES DO CRESCIMENTO DE REDES DE FRANQUIA NO BRASIL 


\section{FATORES DETERMINANTES DO CRESCIMENTO DE REDES DE FRANQUIA NO BRASIL}

Tese Apresentada à Escola Politécnica da Universidade de São Paulo para a obtenção do título de Doutor em Engenharia de Produção

Área de concentração: Engenharia de Produção

Orientador: Prof. Dr. João Amato Neto

São Paulo

2012 


\section{FICHA CATALOGRÁFICA}

Bitti, Eugênio José Silva

Fatores determinantes do crescimento de redes de franquia no Brasil / E.J.S. Bitti - São Paulo, 2012. 200 p.

Tese (Doutorado) - Escola Politécnica da Universidade de São Paulo. Departamento de Engenharia de Produção.

1. Incentivos 2. Monitoramento 3 . Ciclo de vida 4. Franquia 5. Estratégia organizacional I. Universidade de São Paulo. Escola Politécnica. Departamento de Engenharia de Produção Il.t. 


\section{DEDICATÓRIA}

À minha esposa... Paula! Exemplo cotidiano de coragem, convicção e... para mim... de Tamanho!!!

Também à minha mãe... $D$. Sandra. Na questão "Ajuda Eterna", ainda estou em dívida!!! 


\section{AGRADECIMENTOS}

A meu Mestre de Filosofia, Dr. Celso Charuri... Rendo homenagens! Quisera eu alcançar o que tanto pretendo ser: um discípulo!

A meu Pai (in memoriam), cuja dedicação ao trabalho não tenho como esquecer.

Aos meus queridos irmãos, Ingrid e Eduardo, pelas mais diversas manifestações de apoio que recebi.

A meu Amigo André... Sempre a mão estendida manifestando Amizade... Que exemplo!

Ao Prof. Dr. João Amato Neto, meu orientador. Sou grato pela acolhida e confiança.

À Associação Brasileira de Franchising (ABF) nas figuras de Ricardo Camargo e Rogério Feijó.

A meu sogro, Claudino... E claro, minha sogra Eliane, a qual tem participação direta neste trabalho.

A Artur, Raul, Carol, Guilherme e Laura... Todos queridos.

Ao bom Aloízio... Quanta Paciência! O mesmo digo para Fernando e Bianca.

A meus grandes... Grandes Amigos. Izabel, Affonso, Gabi, João Pedro, Soraia, Rosário, Paulo, Cris, Marcelo, Alex, Andrea, Hugo, William, Ana, Alessandra, Silvia, Adriano, Rogério, Margarida, Adauto, Suely... Enfim, a todos os Amigos, conscientes e inconscientes. Muito obrigado.

A meus colegas de FUCAPE... Maira e Jadir, Rodrigo, Fabrício e Vinícius. Adriana e Demuner. Continuo extremamente grato pela convivência daqueles tempos, tão útil até hoje... E também a meus colegas de POLI-USP e FEA pelo convívio.

Minha gratidão à Lídia, Priscila, Marlene e toda equipe do Departamento de Engenharia de Produção da Escola Politécnica da USP.

Minha cara Gilzeli... Assessora para assuntos "excélicos"!!! 
Agradeço ainda a alguns dos "cicerones" que tive na chegada a São Paulo: Prof. Dr. Welington Rocha e Bruno Souza.

A Guiomede Guilardi, Renato Martins e demais colegas que tão bem me receberam na Estratege naqueles árduos primeiros dias em São Paulo. 
"A base falsa, o erro, o princípio que vocês adotaram para a construção de um Mundo Bem Melhor tem sido "modificar o meio para modificar o homem". Ou seja, vocês consideram que o homem é produto do meio. Aí está o erro. Homens que são produto do meio são homens com " $h "$ minúsculo e como poderia alguém pequeno, minúsculo, imperfeito, construir um meio perfeito, maiúsculo?!". 


\section{RESUMO}

Uma das perspectivas pioneiras na explicação do fenômeno franchising é a de que esse formato organizacional proporciona crescimento rápido de redes de unidades de negócio. No entanto, poucos trabalhos empíricos discutem os determinantes do crescimento de redes de franquia. Diferenças entre os setores da indústria e entre as características das redes estão relacionadas a fatores de influência distintos, os quais carecem de investigação. Neste trabalho, 376 redes associadas à Associação Brasileira de Franchising (ABF) foram analisadas para verificar alguns dos determinantes do crescimento do número de unidades na rede. Evitando taxonomias arbitrárias, o estudo segrega as redes em grupos de comportamento estratégico. Tal comportamento deriva diretamente da especificidade de ativos desenvolvidos ao longo do ciclo de vida das redes (efeito path dependence). Testou-se em seguida se o crescimento é afetado pela perspectiva de risco moral de franqueados e pela variação nos incentivos estabelecidos pela rede. Os resultados apontam para efeitos benéficos da reputação e experiência de redes maduras em sua relação com franqueados. Além disso, são obtidos alguns novos insights sobre a relação de redes de franquia com o setor de shopping centers e a presença cada vez maior de redes de franquia em mercados emergentes no cenário brasileiro.

Palavras-chave: franquia, estratégia organizacional, incentivos, monitoramento, ciclo de vida. 


\begin{abstract}
A traditional claim about franchising phenomenon is that this arrangement provides faster network's growing. However, few studies investigate the determinants of growth of franchised chains. Distinctions between both industries and franchise chains issues are related to different influencing factors, which needs further research. In this study, 376 networks associated with the Brazilian Franchising Association (ABF) were analyzed in order to identify some of the determinants of chain size growth (the number of chain's outlets). While it avoids arbitrary taxonomies, the study secretes sample chains into strategic behavior groups. Such a behavior derives directly from the assets specificity developed during the life-cycle of franchised chains in the sample (path dependence effect). Tests were applied checking whether growth is affected by the prospect of franchisees moral hazard, as to the variation in the incentives mechanisms established by franchisors. The results suggest beneficial effects of both reputation and experience in mature chains related associated franchisees. Additionally, the study provides some new insights into the franchise and shopping malls industry interaction, and the increasing presence of franchise networks in emerging markets in the Brazilian scene.
\end{abstract}

Keywords: Franchising, firm strategy, incentives, monitoring, live-cycle. 


\section{Lista de Quadros}

Quadro 1 - Hipóteses Recorrentes na Pesquisa em TA e TRE .........................633

Quadro 2 - Síntese da Literatura usada no Referencial Teórico..........................654

Quadro 3 - Exemplo da Operacionalização da Variável "Mercados Emergentes" (fonte: elaborado pelo autor) . ........................................................... 12021

Quadro 4 - Construtos Teóricos - Determinantes do Crescimento ................... 12122

Quadro 5 - Sumarização dos setores mencionados na ABF ...........................12425

Quadro 6 - Variáveis empregadas na identificação dos grupos estratégicos (fonte: elaborado pelo autor) .................................................................. 13334

Quadro 7 - Variáveis empregadas na análise dos determinantes do crescimento (fonte: elaborado pelo autor) ............................................................ 13435

Quadro 8 - Variáveis em Carney e Gedajlovic (1991) .................................. 13637

Quadro 9 - Hipóteses e construtos em Combs e Ketchen (2003) .....................13637

Quadro 10 - Dimensões e variáveis ................................................... 13738

Quadro 11 - Procedimento de Games-Howell ............................................. 14648

Quadro 12 - Resumo da descrição dos grupos com os determinantes do crescimento das redes vinculadas (fonte: elaborado pelo autor). ...................18183 


\section{Lista de Tabelas}

Tabela 1 - Proporções dos segmentos de franquias no Brasil, entre as redes associadas à $A B F$ e entre as redes da amostra (fonte: $A B F$ ) 1022

Tabela 2 - Comparação do setor de franquias no Brasil com redes associadas à ABF e amostra 1033

Tabela 3 - Correlação de Pearson entre redes no Setor, redes associadas à ABF e redes na amostra 1034

Tabela 4 - Proporção das classes socioeconômicas A e B por municípios ocupados por redes da amostra.

Tabela 5 - Exemplo da Operacionalização da Variável "Mercados Emergentes" Distribuição das lojas nas cidades (fonte: elaborado pelo autor).

Tabela 6 - Exemplo da Operacionalização da Variável "Mercados Emergentes" Proporção das lojas nas cidades ocupadas (fonte: elaborado pelo autor). 11920

Tabela 7 - Estatísticas Descritivas 13233

Tabela 8 - Matriz de correlações de Pearson para as variáveis empregadas na análise fatorial (fonte: elaborado pelo autor). 14041

Tabela 9 - Análise de componente principal - Total da variância explicada 14243

Tabela 10 - Comunalidades. 14244

Tabela 11 - Matriz de Componentes Rotacionados (VARIMAX) 14345

Tabela 12 - Testes Multivariados (MANOVA).

Tabela 13 - Teste de Levene 14547

Tabela 14 - Grupos estratégicos identificados na análise fatorial (fonte: elaborado pelo autor) 14749

Tabela 15 - Média dos valores para cada variável em cada grupo estratégico identificado (fonte: elaborado pelo autor). 14950

Tabela 16 - Distribuição das redes entre os setores da indústria (fonte: elaborado pelo autor) 15051

Tabela 17 - Matriz de correlações de Pearson - Variáveis usadas na análise fatorial, específicas para redes de Rápido Crescimento (fonte: elaborado pelo autor)....15253

Tabela 18 - Matriz de correlações de Pearson - Variáveis usadas na análise fatorial, específicas para redes Maduras (fonte: elaborado pelo autor).

Tabela 19 - Índice Operacional (fonte: elaborado pelo autor) 15759

Tabela 20 - Matriz de correlações de Pearson - Variáveis usadas na análise fatorial, específicas para redes de Alto Investimento (fonte: elaborado pelo autor).

Tabela 21 - Matriz de correlações de Pearson - Variáveis usadas na análise fatorial, específicas para redes Mais Franquia (fonte: elaborado pelo autor). 1602

Tabela 22 - Matriz de correlações de Pearson - Variáveis usadas na análise fatorial, específicas para Redes Metropolitanas (fonte: elaborado pelo autor). 16365 
Tabela 23 - Matriz de correlações de Pearson para as variáveis empregadas na análise dos determinantes do crescimento (fonte: elaborado pelo autor). ..........16567

Tabela 24 - Resultados dos modelos MQO aplicados sobre os grupos .............17173

Tabela 25 - Fatores FIV para multicolinearidade (fonte: elaborado pelo autor).. 17274 


\section{Lista de Figuras}

Figura 1 - Mapa Conceitual da Pesquisa em Franchising …….............................30

Figura 2 - Custos de Monitoramento vs. Arranjo [fonte: adaptado de Bitti (2007)] .498

Figura 3 - Efeito Moderador da Automação [fonte: adaptado de Bitti (2007)]...........51

Figura 4 - Ciclo de Vida (fonte: elaborado pelo autor) ......................................598

Figura 5 - Relação entre Construtos (fonte: elaborado pelo autor).Erro! Indicador não definido. 6

Figura 6 - Operacionalização da variável "densidade" (fonte: elaborado pelo autor). 12627

Figura 7 - Exemplo da operacionalização da variável "Suporte ao Franqueado" (fonte: elaborado pelo autor). 12829

Figura 8 - Comparação entre o crescimento do número de lojas e a evolução do mix contratual (fonte: elaborado pelo autor). 15355

Figura 9 - Comparação entre o crescimento do número de lojas e a evolução do mix contratual - Redes Maduras (fonte: elaborado pelo autor). 15657

Figura 10 - Comparação entre o crescimento do número de lojas e a evolução do mix contratual - Redes de Alto Investimento (fonte: elaborado pelo autor). 1591

Figura 11 - Comparação entre o crescimento do número de lojas e a evolução do mix contratual - Redes Mais Franquia (fonte: elaborado pelo autor). 1613

Figura 12 - Comparação entre o crescimento do número de lojas e o crescimento no setor de shopping centers (fonte: elaborado pelo autor). 1624

Figura 13 - Comparação entre o crescimento do número de lojas e a evolução do mix contratual - Redes Metropolitanas (fonte: elaborado pelo autor). 164 


\section{Sumário}

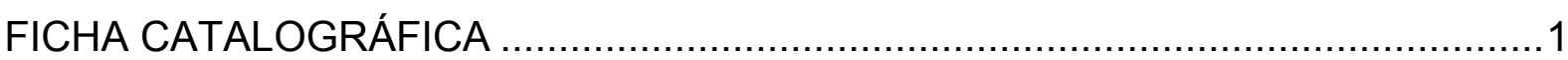

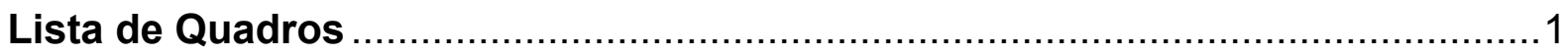

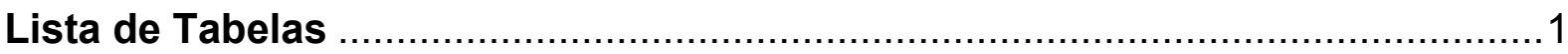

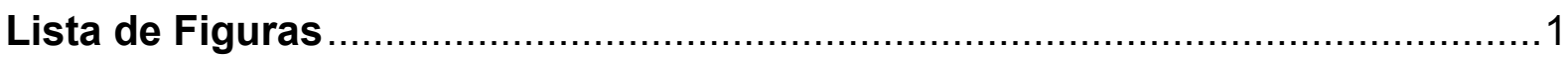

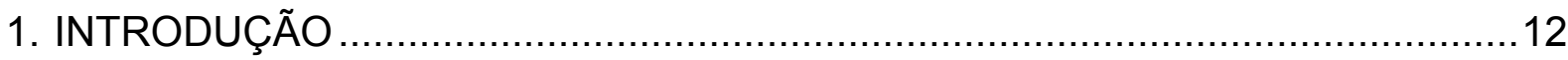

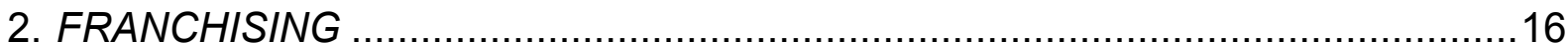

2.1. Breve Histórico do Setor .......................................................... 16

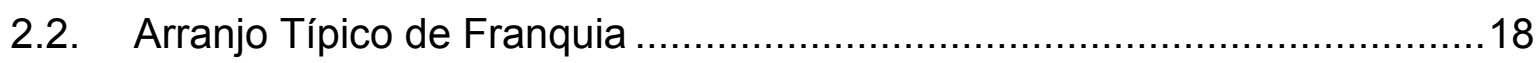

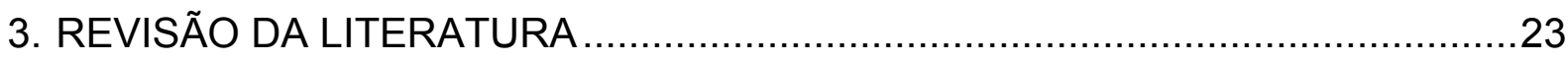

3.1. Restrições ao Crescimento em Redes de Franquia ...............................31

3.2. Mecanismos de Incentivo e Coordenação................................................. 34

3.3. Taxas Fixas de Franquia e Taxas de Royalties...................................... 37

3.4. Riscos Comportamentais do Franqueado ..........................................40

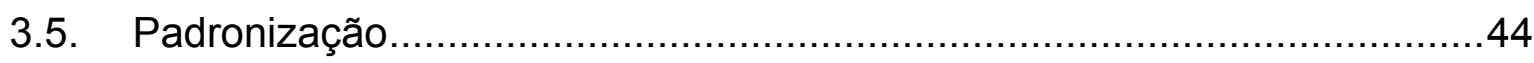

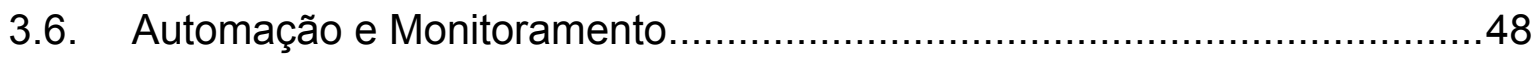

3.7. Suporte ao Franqueado como Controle ............................................. 53

3.8. Comportamento Estratégico no Ciclo de Vida ......................................54

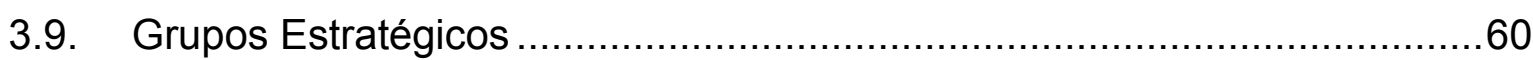

3.10. Síntese da Literatura em Franchising ................................................63

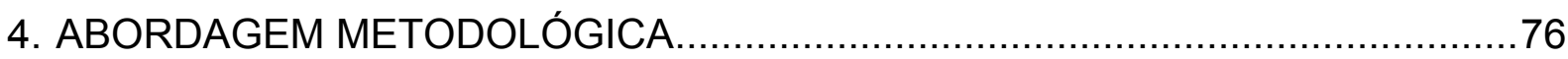

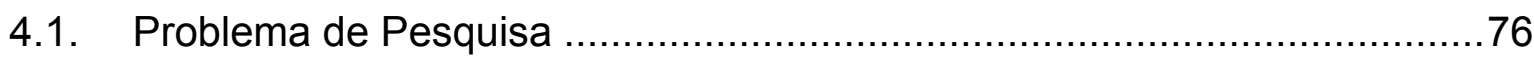

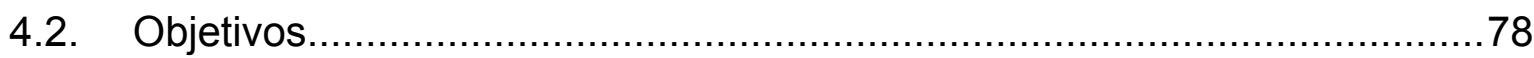

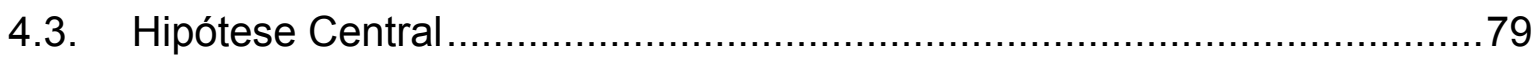

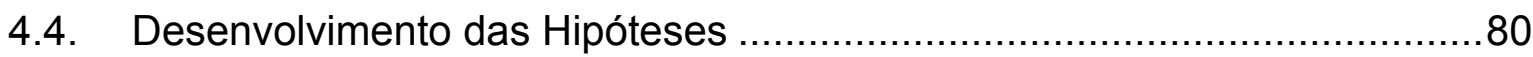

4.4.1. Risco na Operação ................................................................. 80

4.4.2. Dinâmica de Incentivos ........................................................... 83

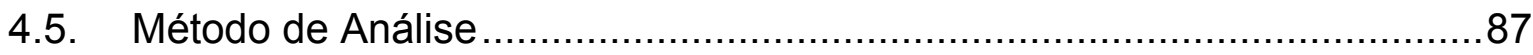

4.6. Controle para Endogeneidade dos Dados......................................90

4.7. Inadequações dos Modelos Tradicionais ......................................... 91

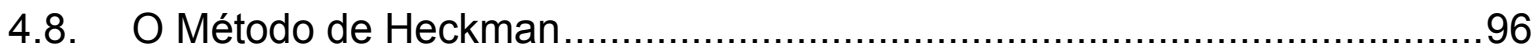

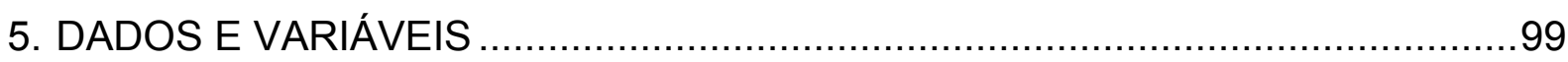

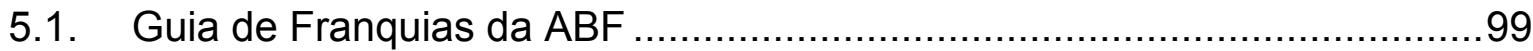

5.2. Outras Fontes de Informação .........................................................100

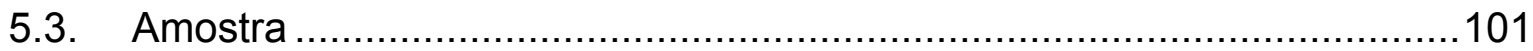

5.4. Dados de Dispersão ................................................................... 105 


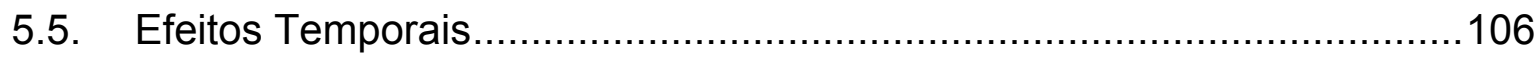

5.6. Informações Complementares..........................................................106

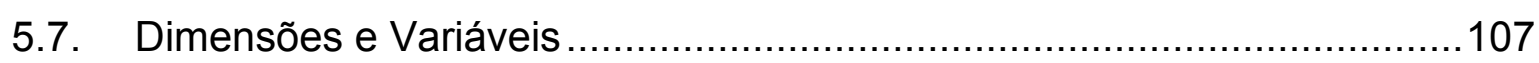

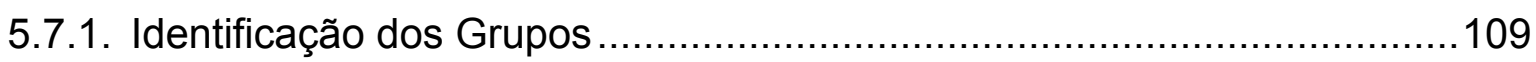

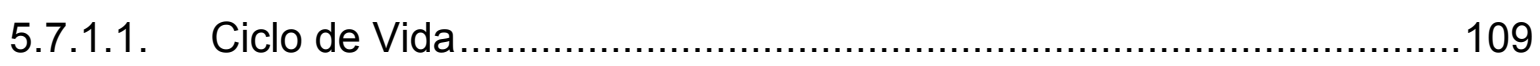

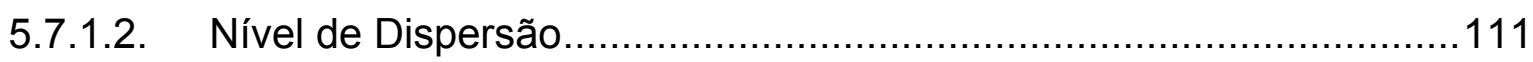

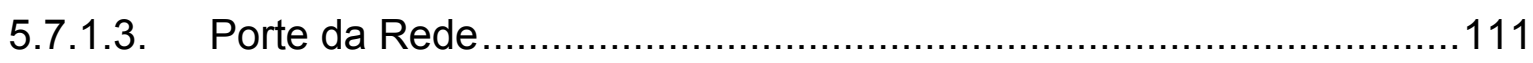

5.7.1.4. Estratégia de Preços - Taxas de Franquia .......................................112

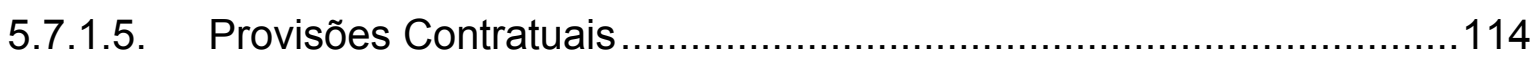

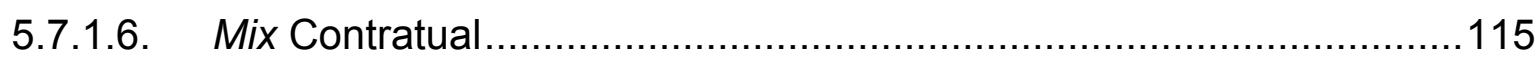

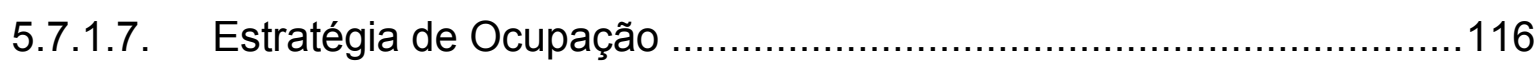

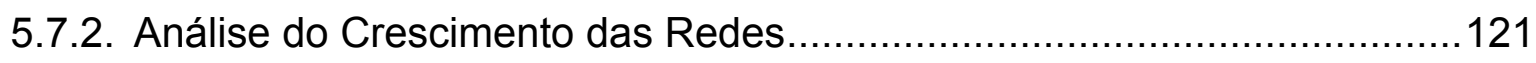

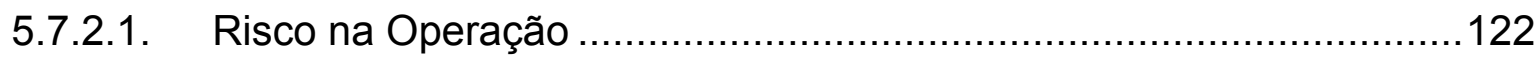

5.7.2.2. Atratividade e Modalidade de Incentivos .......................................129

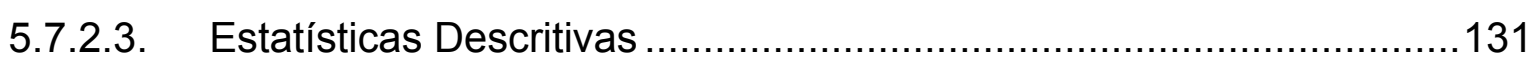

6. IDENTIFICAÇÃO DOS GRUPOS ESTRATÉGICOS .......................................135

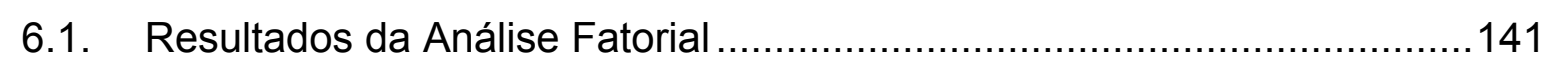

6.2. Verificação da Diferenciação entre Grupos .............................................144

6.3. Nominação e Análise dos Grupos Estratégicos.....................................147

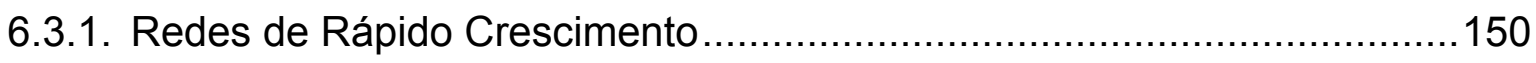

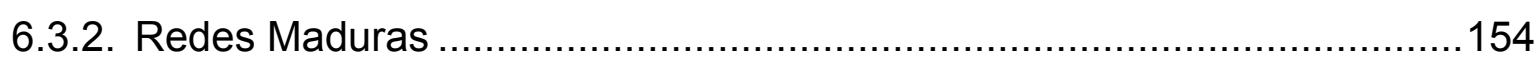

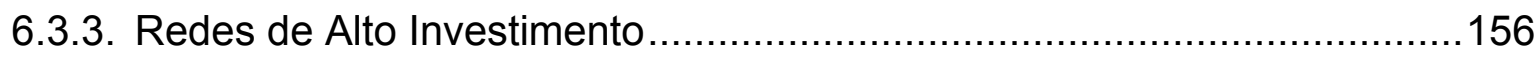

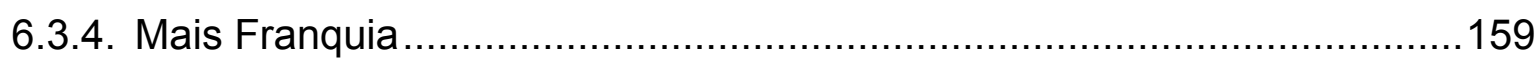

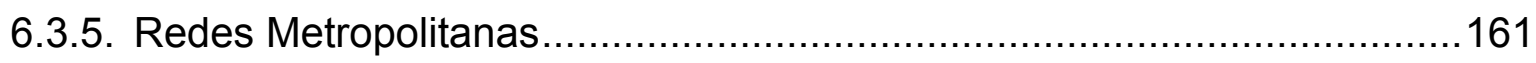

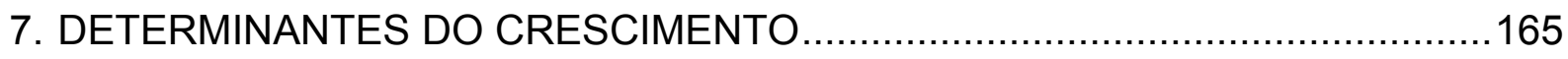

7.1. $\quad 1^{\circ}$ Estágio - Modelo Multinomial Logit..................................................165

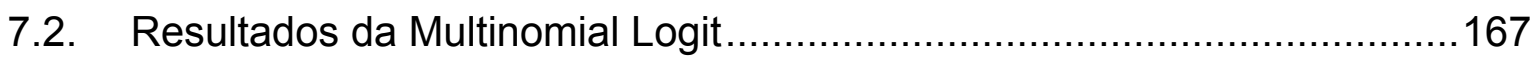

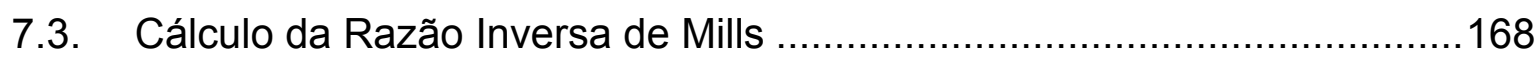

7.4. $\quad 2^{\circ}$ Estágio - Modelos MQO de Crescimento …....................................170

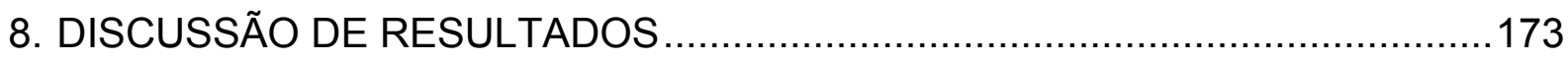

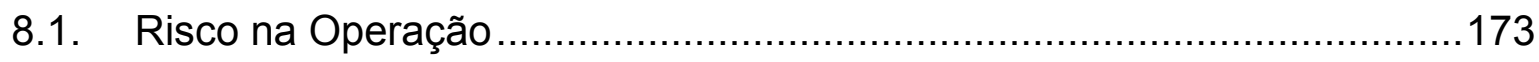

8.2. Balanceamento entre Modalidades de Incentivos ................................177

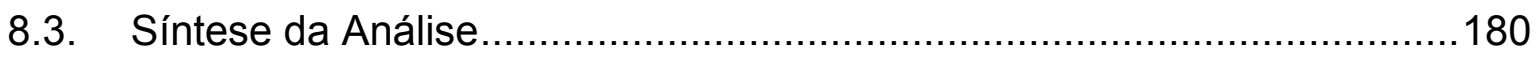

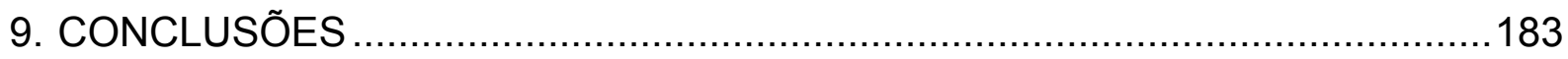

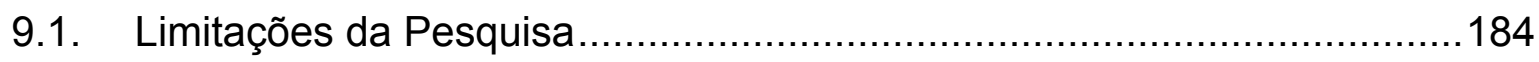

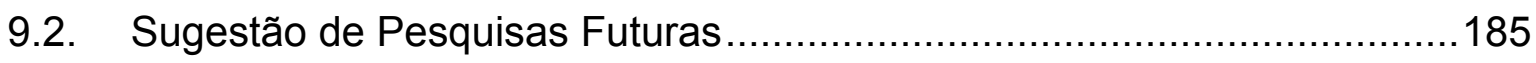


10. REFERÊNCIAS 


\section{INTRODUÇÃO}

O sistema de franquias é um recorrente formato organizacional presente em setores diversos, tais como clínicas estéticas, assessoria contábil e fast-food, por exemplo. Tipicamente, franqueadores permitem que operadores locais licenciados (franqueados) usem e promovam sua marca e formato de negócios em troca de uma combinação de taxas fixas e royalties contínuos ( $R O H, 2002)$. O sistema de franchising é percebido como um poderoso veículo de expansão e crescimento de firmas em diversos setores da economia.

Baseado principalmente na teoria da agência, um consistente corpo de literatura tem investigado arranjos de franquia. Nesta abordagem, contratos de franquia são explicados em termos de custos de agência, isto é, os custos de se manter alinhados os interesses do Principal (o franqueador) e dos Agentes (operadores locais) com relação ao desempenho da parceria. Nessa vertente, franquias representam alternativas a problemas de coordenação e monitoramento de firmas com múltiplas unidades geograficamente dispersas. Ou seja, o gerente da unidade é convertido em proprietário, de forma que sua remuneração e aumento de patrimônio dependem do bom desempenho da loja.

Dentre os mais recorrentes objetos de estudo nesta vertente teórica estão os determinantes da proporção entre lojas próprias e franqueadas (BRADACH, 1997, LAFONTAINE; SHAW, 2005), o equilíbrio entre taxas fixas e variáveis em acordos de franquia (BRICKLEY, 2002; VASQUEZ, 2005; MARUYAMA; YAMASHITA, 2008), custos de monitoramento (PENÁRD et al., 2003), controle do oportunismo de franqueados (CHAUDEY; FADAIRO, 2008; BOULAY, 2010), dentre outros.

No entanto, poucos trabalhos empíricos têm se voltado para verificar como estes aspectos influenciam a dinâmica do crescimento de redes de franquia. Dentre as exceções identificadas na literatura, algumas pesquisas sugerem que o crescimento das redes depende de sua capacidade de atrair parceiros através de diversas decisões estratégicas, tais como a política de preços e a alocação de propriedade entre lojas próprias e franqueadas (CASTROGIOVANNI; JUSTIS, 2002; SHANE et al., 2006). 
Mesmo vertentes alternativas e/ou complementares à teoria da agência, como a teoria dos recursos escassos (pioneira no estudo de franquias), não indicam quais seriam os determinantes do crescimento de redes de franquia, embora tenha 0 crescimento como principal motivador para que firmas adotem o arranjo [uma exceção é SEN (1998)].

Sendo assim, a presente pesquisa busca preencher esta lacuna. Isto é, pretende-se investigar e distinguir determinantes do crescimento do número de lojas em redes de franquia no Brasil. Para isso, seguem-se as tendências mais recentes na pesquisa em franchising quanto a abordagens multiteóricas (COMBS et al., 2010). Assim, esta pesquisa é conduzida agregando contribuições da teoria da agência, teoria dos recursos escassos e economia dos custos de transação.

Dadas as naturais diferenças tanto entre os diversos setores como entre as muitas redes de franquia, é natural que os efeitos de fatores de influência sobre o crescimento das redes não se dê de forma homogênea, variando de acordo com alguns atributos desenvolvidos e adquiridos por estas redes ao longo de seu ciclo de vida. A identificação de tais atributos permitiria interpretar aspectos do comportamento estratégico destas firmas, o qual é resultante de um processo histórico de interação entre as redes e forças de mercado (path dependence).

Uma vez identificados tais atributos, torna-se possível identificar também grupos de redes com atributos similares entre si, os quais são aqui denominados grupos estratégicos. No caso, o perfil estratégico de cada grupo não se refere à estratégia enquanto posicionamento ex ante (PORTER, 1979; MINTZBERG, 2000), mas à estratégia enquanto resultado do caminho percorrido pelas redes do grupo ao longo do ciclo de vida.

$\mathrm{Na}$ medida em que as redes amadurecem, o nível de especificidade dos ativos empregados ao longo da trajetória se eleva. A identidade visual da marca, o treinamento específico dos operadores locais, maquinário, mobília e outros são altamente relacionados ao curso histórico da rede. Isso estaria ainda refletido nas políticas de atração de franqueados, na alocação de propriedade de lojas, nas técnicas de monitoramento empregadas, etc. Tal nível de especificidade resultaria em elevados custos de mudança de comportamento. 
Considerando grupos de redes com comportamento similar, as quais lidam com elevados custos de mudança, observa-se uma condição de relativa estabilidade entre os grupos. Esta condição de estabilidade entre os grupos torna possível obter uma taxonomia de grupos estratégicos. Alguns trabalhos anteriores sugerem métodos para identificação e interpretação destes grupos, normalmente através de análise fatorial (CARNEY; GEDAJLOVIC, 1991; CATALUÑA et al., 2007; MARTÍNEZ-TORRES; TORAL-MARIN, 2009). Assim, também aqui essa metodologia é aplicada.

Neste estudo, 376 redes de franquia operando em território brasileiro foram analisadas. Inicialmente, através de análise fatorial, 5 grupos são identificados com base em atributos das redes relacionados a ciclo de vida, dispersão de lojas, porte, estratégia de preços, provisões contratuais e mix contratual (a proporção de lojas próprias e franqueadas). Os resultados obtidos se assemelham aos verificados em estudos anteriores relacionados a grupos estratégicos em franquias (CARNEY; GEDAJLOVIC, 1991; CATALUÑA, et al., 2007).

Após a identificação dos grupos estratégicos, são propostos dois construtos representando fatores determinantes do crescimento das redes. O risco na operação decorre do risco de comportamento oportunista de franqueados. No caso, são operacionalizadas variáveis captando ações das redes para mitigar os efeitos do oportunismo.

O segundo construto está relacionado com mecanismos de incentivos empregados pelo franqueador. Tais incentivos são considerados em sua dimensão vertical (relacionados à decisão de franquear uma unidade) e horizontal (relacionados às políticas de taxas de franquia das redes). As variáveis captam a variação destes incentivos ao longo do tempo.

Uma vez que os grupos diferem em atributos, o efeito destas variáveis ocorre de uma forma não homogênea entre os grupos. Os resultados indicam crescimento no número de unidades de todos os grupos, indicando que as redes se beneficiam do atual momento da economia brasileira. No entanto, existe grande variação na influência dos fatores empregados no modelo de análise.

O aumento da proporção de lojas franqueadas e a dificuldade do franqueado em extrair valor da marca de forma oportunista exercem influência praticamente em 
todos os grupos. Por outro lado, a variação nas taxas de franquia e o controle do comportamento de franqueados têm sua influência condicionada ao perfil de cada grupo. Poucos são os efeitos notados decorrentes da capacidade de monitoramento à distância das redes e da conversão de lojas próprias em franqueadas.

Os resultados também parecem confirmar os modelos de equilíbrio de taxas de franquia baseados no risco moral bilateral. Ou seja, as taxas se adéquam para compensar a parte mais importante para o sucesso da operação. Enquanto que em redes jovens o crescimento depende da atração de um grande número de franqueados através de taxas mais baixas, em redes maduras, o crescimento é obtido mesmo com as redes elevando estas taxas.

Além dos resultados em si, espera-se que a pesquisa contribua com aspectos não muito explorados pela literatura (nacional e estrangeira), tais como a relação entre franquias e shopping centers, o aumento da presença de redes de franquia em mercados emergentes no cenário brasileiro, além da própria a discussão a respeito de grupos estratégicos entre redes de franquia no Brasil.

O trabalho está organizado da seguinte forma: os capítulos 2 e 3 fazem a discussão conceitual; os capítulos 4 e 5 abordam a parte metodológica do estudo, os capítulos 6, 7 e 8 compreendem testes e resultados, com o fechamento do estudo contido no capítulo 9 . 


\section{FRANCHISING}

\subsection{Breve Histórico do Setor}

O termo "franchising" deriva do francês "franc", que significa a transferência de um direito, outorga de um privilégio ou concessão exclusiva. Enquanto arranjo produtivo, o sistema de franquias constitui um formato de distribuição no qual um fornecedor concede à outra parte interessada o direito de transacionar produtos ou serviços, conforme termos e condições pré-estabelecidos em contrato durante certo período e em uma área ou região específica.

Trata-se de um arranjo de distribuição de bens e serviços pelo qual uma empresa (franqueadora) cede o direito de uso de seu nome, seu logotipo, know how e tecnologia, mediante o pagamento de taxas a um terceiro, que se torna um franqueado com determinados direitos e obrigações para com o detentor da marca.

O sistema de franquias é considerado o mais antigo dos arranjos "entre firmas" (MICHAEL, 2000a). Apesar de registros históricos indicando a existência de contratos de exclusividade na comercialização de bebidas na Inglaterra do início do século XIX (MENDELSOHN, 2004, p. 16) o sistema de franquias efetivamente surge nos EUA após a guerra de secessão, na segunda metade deste mesmo século (HACKETT, 1976). Ainda nesta época, a Singer Sewing, empresa do ramo de máquinas de costura, estabeleceu uma rede de concessionários independentes para comercialização de seus produtos.

Desta época em diante, verifica-se a adoção do arranjo por corporações americanas. A General Motors, por exemplo, em 1898 passa a utilizar revendedores independentes para expansão de seus postos de venda (LAFONTAINE; MORTON, 2010). Em 1904 a Coca-Cola Company já havia estabelecido acordos que permitiram a 123 plantas independentes engarrafarem e venderem seu refrigerante (KATZ, 1978).

Já no século $X X$, a década de 50 foi marcada por um destacado crescimento do modelo de franquias nos EUA. Grandes redes como a McDonald's, Burger King e Dunkin' Donuts expandiram-se de forma vigorosa com base na concessão de licenças de franquia. A literatura relaciona o fenômeno de expansão do sistema a 
fatores como o advento da mídia através da popularização da televisão, o aumento na malha viária dos EUA, a massificação do turismo (com os consumidores preferindo exercitar sua experiência de consumo em empresas com marcas conhecidas) e ao próprio aumento da renda das famílias norte-americanas (MATHEWSON; WINTER, 1985).

No Brasil, a adoção do modelo de franquias teve início em 1963 com a rede de ensino de idiomas Yázigi. No entanto, apenas na década de 1970 observou-se um incremento mais nítido do arranjo no país, principalmente pela chegada de redes internacionais como a McDonald's (que operava apenas com unidades próprias) e a adoção do modelo por empresas nacionais, como O Boticário e Bob’s.

Levantamentos conduzidos pelo Ministério do Desenvolvimento, Indústria e Comércio Exterior (MDIC) e pela Associação Brasileira de Franchising (ABF) indicam que o setor gerou faturamento acima de $\mathrm{R} \$ 75$ bilhões no ano de 2010 , gerando quase 800 mil empregos diretos em todo o país. Neste mesmo ano, foram reconhecidas 1.855 redes franqueadas no Brasil (210 abertas no ano de 2010), as quais operam mais de 86 mil unidades entre lojas próprias e franqueadas. Atualmente 70 redes brasileiras operam internacionalmente com unidades em 49 países (fonte: ABF, 2011).

Em 1987 foi criada a Associação Brasileira de Franchising (ABF), entidade sem fins lucrativos que busca promover o setor no Brasil. Constituída por redes de franquia, a ABF também é representada pela associação de franqueados e indivíduos relacionados ao sistema como consultores e advogados. Entre suas atribuições, fornece aos associados mediação em litígios, cursos temáticos e organização de feiras do setor. Conta atualmente com cerca de 900 associados e mantém relações com outras organizações similares em países como Argentina, Chile, México e Estados Unidos, além de ser membro fundador da WFC (World Franchise Council).

A ABF divulga ao público externo informações sobre o setor, tais como dados estatísticos do segmento no Brasil, custos de aquisição de franquias (das redes associadas), taxas de royalties praticadas e o capital para abertura de lojas, através de anuários e de seu sítio na internet, além de publicações técnicas de especialistas em franchising. 
Dois fatos institucionais marcantes que contribuíram para o fortalecimento do setor no Brasil ocorreram na década de 1990. Em 1994, promulga-se a Lei $n^{\circ}$ 8.955/94, regulamentando contratos de franquia empresarial no país (VANCE, 2010; CHERTO et al., 2006). Em 1997 foi criada a Câmara Setorial de Franquia Empresarial no então Ministério da Indústria, Comércio e Turismo (MICT), a qual permaneceu ativa até 2000. A partir de 2004, o Ministério do Desenvolvimento, Indústria e Comércio Exterior (MDIC) institui o Fórum Setorial de Franquias (VANCE, 2010), cujas atribuições estavam voltadas para auxiliar a internacionalização de redes brasileiras além de fomentar o desenvolvimento e consolidação do setor (MDIC, 2004).

Dados mais recentes fornecidos pela ABF indicam um faturamento bruto de $\mathrm{R} \$ 49$ bilhões em 2011. Operam no Brasil cerca de 2000 redes de franquia com 95 mil unidades nos mais diversos segmentos do varejo, alimentação, instrução, dentre outros. O setor gera quase 800 mil empregos diretos. Atualmente, cerca de 80 marcas brasileiras estão presentes em 50 países. A recíproca é verdadeira, uma vez que a estabilidade e os bons números da economia nos últimos 10 anos atraíram para o país 59 redes estrangeiras com cerca de 6600 unidades.

\subsection{Arranjo Típico de Franquia}

Em arranjos de franquia, o proprietário de um conceito de serviço (principal/franqueador) celebra um contrato com a uma parte independente (agente/franqueado) no qual esta última é licenciada para usar o modelo de negócios para venda de bens ou serviços sob a marca do franqueador. No entanto, o principal não investe fundos próprios na unidade de serviço local, sendo o franqueado quem assume a responsabilidade pela construção, manutenção e gestão da operação local (FLADMOE-LINDQUIST; JACQUE, 1995).

O Departamento de Comércio do governo dos EUA distingue as modalidades de franquia como "franquias de marca", "franquias de produto" e "franquias de formato de negócio" (KLEIN, 1995) ${ }^{1}$. O primeiro caso abrange franquias que se caracterizam por possuírem apenas a licença restrita de uso da marca e distribuição

\footnotetext{
${ }^{1}$ No Brasil esta mesma distinção é adotada, ainda que algumas vezes estes tipos de franquia sejam tratados como franquias de primeira, segunda e terceira geração sucessivamente (BRASIL, 2005).
} 
do produto, com ou sem exclusividade e com pouco ou quase nenhum suporte operacional e mercadológico do franqueador. Exemplos desta modalidade de franquias estão nos revendedores de automóveis, engarrafadores de bebidas e postos de combustíveis (VANCE, 2010).

A segunda modalidade (franquia de produtos) é um aprimoramento da anterior no sentido em que apresenta como diferencial o fato de os franqueados constituírem canais exclusivos de distribuição para franqueadores (SILVA, 2004). O franqueador é o único fornecedor e os royalties normalmente estão embutidos no preço praticado junto ao franqueado.

Por fim, nas chamadas franquias de formato de negócio a relação franqueador/franqueado não é composta apenas do produto, serviço ou marca, mas do formato do negócio em si: estratégia e planos de marketing, manuais e normas de funcionamento, controle de qualidade e uma contínua comunicação de duas vias. Em troca os franqueadores recebem pagamentos de royalties e/ou outras taxas (aquisição, fundo de promoção e publicidade, etc.). A produção, entretanto, ocorre no ponto de venda como é o caso de redes de fast-food, por exemplo (LAFONTAINE; SLADE, 1996). Tais arranjos apresentam alto grau de padronização e, muitas vezes, são considerados os verdadeiros exemplos de franchising por economistas (KLEIN, 1995) ${ }^{2}$.

Franquias de formato de negócios estão presentes em uma considerável variedade de indústrias, desde internet até financeiras, embora sejam mais comuns nos setores de alimentação, serviços, negócios e varejo (LAFONTAINE, 1992; SHANE, 1996; SHANE; FOO, 1999). A franquia de formato de negócio, com o franqueador fornecendo um marketing detalhado em conjunto com acompanhamento continuo, tornou-se um modelo padrão no setor de serviços em mercados mais maduros como o dos EUA (HENNESSY, 2003).

Em geral, franquias de formato de negócio consistem de um conjunto patenteado de procedimentos em conformidade com a especificação do franqueador. Não é surpresa que o sistema de franquias esteja intimamente

2 Alguns autores ainda mencionam franquias de $4^{a}$ e $5^{a}$ geração, as quais seriam sofisticações das franquias de formato de negócio quanto a práticas de gestão e estabelecimento de contratos menos rígidos. No entanto, estas modalidades não são uma recorrência no mainstream das áreas de conhecimento pesquisadas, de forma que se optou por não abordá-las aqui. 
associado com empresas de serviços que detêm marcas fortemente identificáveis, as quais atestam ao consumidor a qualidade uniforme do produto nos diversos estabelecimentos (FLADMOE-LINDQUIST; JACQUE, 1995).

O sistema de franquias pode ser analisado pela perspectiva dos arranjos de governança (MENARD, 2004). Existe uma grande diversidade de arranjos intermediários entre operações de mercado e o modelo de firma verticalmente integrada (hierarquia). Alguns exemplos podem ser vistos em joint ventures, contratos de terceirização e franchising. Especificamente no caso do varejo, independente do arranjo escolhido para organizar o processo produtivo - integração ou separação vertical - há a necessidade de delegar atividades de vendas a um agente. A diferença entre as opções orbita em torno da maneira com a qual o agente é compensado (LAFONTAINE; SLADE, 1996).

Diferentemente da firma verticalmente integrada e baseada em vínculos trabalhistas, em relação ao operador local, esta modalidade de arranjo apresenta relacionamentos contratuais com duração preestabelecida desde o início da relação ${ }^{3}$. Além disso, enquanto na firma clássica o único insumo demandado ao agente é o trabalho, em contratos relacionais como os de franquia o agente também entra com o capital.

Em acordos de franquia, o proprietário de uma marca protegida concede a outra pessoa (física ou jurídica) o direito de operar sob sua marca com a finalidade de produzir ou distribuir um produto ou serviço em troca de algum tipo de compensação (CAVES; MURPHY, 1976; AZOULAY; SHANE, 2001). Normalmente estes contratos consistem de duas modalidades de pagamento do franqueado ao franqueador. Em um primeiro momento paga-se uma taxa fixa inicial e não reembolsável e, ao longo da relação, ocorre o pagamento de algum tipo de royalties contínuos (BRICKLEY, 1999, 2002; KALNINS; MAYER, 2004; SHANE et al., 2006).

Os royalties normalmente são baseados em vendas ao invés de lucros. Uma explicação para isso é o fato de que o franqueador pode documentar vendas com mais facilidade do que os lucros (que podem ser afetado por alocação arbitrária de custos, etc.) (BRICKLEY, 2002).

\footnotetext{
${ }^{3}$ Não estão considerados nesta assertiva os contratos de máster franquia. Nesta modalidade, o franqueado possui mais de uma unidade e tende a estabelecer relações trabalhistas e hierárquicas com os gerentes locais de suas unidades.
} 
Em contrapartida, franqueados obtêm o direito de usar o capital da marca do franqueador, bem como seu método de operação. Além disso, o franqueador fornece suporte contínuo ao franqueado. No entanto, o franqueador mantém o direito de rescindir unilateralmente o contrato se for verificado que o franqueado não está entregando um produto consistente com os padrões de qualidade garantidos pela marca (WIMMER; GAREN, 1997).

O arranjo tem como características centrais o arrendamento de um ativo proprietário intangível e a operação do processo de produção ou distribuição de forma descentralizada (THOMPSON, 1994).

No processo de expansão da rede ${ }^{4}$, ao estabelecer novas unidades em áreas de interesse, o franqueador decide entre conceder a operação da nova unidade a um novo franqueado, selecionar entre franqueados já existentes ou, ainda, operar a nova unidade como loja própria. Se a opção for conceder uma nova unidade a um dos atuais franqueados, a rede prospecta a melhor localização para a nova unidade (KALNINS; LAFONTAINE, 2004).

Uma vez feita a opção por franquear uma unidade, normalmente, aloca-se ao agente a propriedade de pelo menos parte dos ativos locais. Ou seja, parte da riqueza destes indivíduos será comprometida na relação contratual (ao contrário do que ocorre com gerentes contratados como empregados). Até por isso, a posse destes ativos tem papel fundamental na determinação dos incentivos ao desempenho, independente do regime de compensação alternativa viável (LUTZ, 1995).

Alguns direitos de decisão, como a seleção cardápio e os projetos predial/arquitetônico, por exemplo, são normalmente centralizados pelo franqueador, enquanto decisões quanto à contratação de pessoal e determinado nível de publicidade local são descentralizados para o franqueado (HUANG, 1995; MACHOSTADLER; PEREZ-CASTRILLO, 1998).

Na comparação entre unidades próprias e franqueadas, estas últimas mantém liberdade de ação relativamente maior, ainda que ponderada por especificidades

\footnotetext{
${ }^{4}$ O termo "rede" é aplicado em quase todos os tipos de arranjos contratuais recorrentes entre entidades autônomas (MÉNARD, 2004). Especificamente no caso do presente estudo, o termo é aplicado para resumir e representar um conjunto de unidades de produção (ou lojas) com uma coordenação central.
} 
contratuais e/ou institucionais (nível de enforcement ${ }^{5}$ ) e pela eficiência do monitoramento empreendido pelo franqueador.

O arranjo de franquias ainda se diferencia na questão do direito residual sobre o lucro da unidade. A rede abre mão de parte do resíduo em troca de taxas iniciais de franquia, royalties e fundos de publicidade e promoção, por exemplo. Por outro lado, é frequentemente assumido que o salário de gerentes contratados é fixo, ou dotado de algum tipo de bonificação variável sobre desempenho. Mesmo no caso da presença da remuneração variável, os incentivos obtidos pelo esquema de contratação com vinculo trabalhista são menos efetivos do que aqueles dispostos no arranjo de franquias (KRUEGER, 1991).

${ }^{5} \mathrm{O}$ termo enforcement neste trabalho difere daquele empregado na literatura econômica nacional. Nesta, o termo se aproxima do significado de coerção sobre a obrigação de contratos. $O$ termo gera certas ambiguidades, até pelas diferentes definições dentro da própria literatura econômica internacional. North (1991) define enforcement como a garantia da efetividade e aplicabilidade das instituições que restringem a interações entre indivíduos (a lei, por exemplo). Ou seja, o termo se confunde com coerção. Greif (1994) e Aoki (2001, p. 41) distinguem enforcement de coerção. Coerção, para estes autores, é o poder de fazer com que se cumpra a norma dada mediante restrição e punição; enquanto suas definições para o termo estão baseadas nas crenças dos indivíduos com relação à aplicabilidade e efetividade da norma sobre a interação entre os agentes. Nesta pesquisa o termo se aproxima dessa segunda definição. 


\section{REVISÃO DA LITERATURA}

Várias correntes de pensamento derivadas, sobretudo, dos trabalhos de Coase (1937) se voltam para o entendimento dos limites e da própria razão da existência das firmas. Furubotn e Richter (2000, p.13), mencionam algumas dessas novas abordagens contidas no arcabouço da "moderna economia institucional", tais como a economia dos custos de transação, a abordagem dos direitos de propriedade, contratos incompletos, a nova visão institucional, dentre outras. Esta Nova Economia Institucional (NEI) representaria assim um termo genérico para representar o arcabouço teórico de onde derivam estas vertentes. Para os autores trata-se de uma escola de pensamento, cujo conjunto de ideias apoia-se na importância das instituições e no conceito de custos de transação ${ }^{6}$.

Estas visões rompem com o paradigma da "caixa preta" da economia neoclássica. Ou seja, a firma deixa de ser vista como mera função produção; um conjunto de atributos tecnológicos de transformação de insumos produtivos, reagindo mecanicamente ao ambiente (TIGRE, 1998). Enquanto a teoria da firma neoclássica tem sido bastante útil no entendimento da formação dos preços de mercado, a chamada nova teoria da firma se volta para o entendimento da mesma enquanto entidade legal (KLEIN, 2000).

Algumas destas vertentes abordam a relação entre produtores e varejistas e se baseiam na ideia de que resultados first-best irrestritos não podem ser alcançados devido à presença de custos de coordenação no arranjo (LAFONTAINE; SLADE, 1996). Tais custos estão relacionados com monitoramento do esforço do agente contratado, incentivos ao desempenho, desenho e obrigação de contratos.

Diferentes vertentes da chamada teoria da firma têm abordado a presença destes custos na organização da produção. Dentre muitas, podem ser citadas a teoria da agência, contratos incompletos, direitos de propriedade, economia dos custos de transação (ECT), e outras que serão eventualmente mencionadas ao longo deste trabalho. Embora dotadas de certas especificidades em forma e

${ }^{6}$ Tais custos representam os "[...] custos ex ante de preparar, negociar e salvaguardar um acordo bem como os custos ex post dos ajustamentos e adaptações que resultam, quando a execução de um contrato é afetada por de falhas, erros, omissões e alterações inesperadas. Em suma, são os custos de conduzir o sistema econômico" (WILLIAMSON, 1993). 
terminologia (por exemplo, custos de agência e custos de transação), percebe-se ser comum a estas perspectivas dois pressupostos comportamentais básicos: o oportunismo (mesmo que potencial) e a racionalidade limitada de indivíduos.

O conceito de oportunismo resulta da ação de indivíduos na busca por satisfazer interesses orientados por sua própria função utilidade. A definição de Simon (1985) sobre o oportunismo de indivíduos é contestada por Williamson (2000). Para o primeiro, o oportunismo decorre de uma fragilidade emocional; para o segundo, trata-se de ações individuais de cunho estratégico resultando em má adaptação contratual (MARINO; ZYLBERSZTAJN, 2002). A assimetria informacional potencializa ações oportunistas.

O oportunismo potencial de indivíduos eleva riscos de perdas decorrentes de um contrato ineficientemente desenhado ou uma baixa capacidade de monitoramento ou mensuração de desempenho podem motivar comportamentos inadequados.

Partes contratuais incorrerão em despesas ante a perspectiva de comportamento inadequado das respectivas contrapartes. Tais despesas ou custos de coordenação decorrem das ações ex ante e ex post tomadas com intuito de lidar com o problema de oportunismo (monitoramento, elaboração de contratos mais completos, etc.). Na busca por mitigar eventuais perdas, os agentes podem optar por arranjos menos eficientes para conduzir determinada transação. A tais perdas este trabalho denomina custos de coordenação.

O segundo pressuposto comportamental baseia-se no entendimento que, ao contrário da racionalidade individual perfeita assumida na visão neoclássica, os indivíduos desejam ser racionais, mas apenas o são de forma limitada (SIMON, 1961, p. 24). O ser humano é cognitivamente limitado, não sendo possível a ele antever e controlar para todas as contingências possíveis. A capacidade de coletar/processar informações também é limitada, pois apresenta retornos decrescentes de escala determinados pela tecnologia de informação presente.

Quando relacionados, estes pressupostos sustentam a alegação de que contratos serão inerentemente incompletos. Ou seja, não é possível desenhar cláusulas para a totalidade de incertezas contratuais. As razões de Klein (1978) para incompletude contratual estão intimamente ligadas aos pressupostos supracitados: 
(i) desenhar contratos mais completos demanda a aquisição de conhecimentos distintos e específicos para cada seara contemplada pelo instrumento (custos ex ante) e (ii) monitorar, mensurar e obrigar contratos incluem custos que tendem a se elevar com a complexidade da função contratada (custos ex post).

Por sua vez, arranjos contratuais incompletos abrem espaço para arestas na relação entre as partes. Mantendo-se constante os efeitos do oportunismo, ainda assim, divergências podem decorrer por uma alteração no ambiente de contratação. Rupturas relacionadas a fenômenos naturais, choques tecnológicos ou mudanças no ambiente institucional podem gerar falta de entendimento entre as partes simplesmente porque o novo cenário em nada se assemelha ao quadro original quando da assinatura do contrato. No limite, tal divergência pode ser mostrar inalcançável mesmo para um árbitro externo, o que potencializa os custos da divergência (BARZEL, 2005).

Tais incompletudes podem incentivar agentes oportunistas a renegarem o contrato previamente acordado, buscando benefícios próprios ao tirar proveito de elementos não especificados ou não aplicáveis à relação contratual. Mesmo no curso normal da contratação, não é possível ao contratante antecipar todas as ações e intenções da parte contratada. Isso implica que sempre haverá algum grau de assimetria de informação entre as partes.

A assimetria de informação está na base dos problemas de risco moral e seleção adversa (moral hazard e adverse selection). O risco moral é relacionado às dificuldades de observar (ou verificar) todas as ações da contraparte contratual (DESAI; SRINIVASAN, 1995). Ou seja, uma vez que o acordo é firmado, o agente poderá não agir conforme o prometido caso o contratante não consiga mensurar a desempenho contratual.

Quando, sob assimetria de informação, agentes conseguem omitir ou distorcer informações a seu respeito, um quadro de seleção adversa pode tomar forma (BARTHÉLEMY, 2011). O problema da seleção adversa ocorre quando contratantes elevam os custos ex ante de contratação visando se proteger de comportamento oportunista (AKERLOF, 1970).

Esse é o caso, por exemplo, do setor de seguros de automóveis. O valor do prêmio a ser pago pelo segurado pode repelir proprietários mais zelosos, uma vez 
que estes sabem ser menor a probabilidade de terem seu veiculo furtado ou de se envolverem em acidentes. Por outro lado, proprietários com maior probabilidade de incorrerem nestes eventos serão atraídos mesmo com prêmios maiores. Assim, a elevação do preço da apólice atrai justamente aqueles agentes considerados mais indesejados.

As barreiras criadas podem alcançar um montante que supera o preço de reserva de bons agentes, afastando-os do processo de seleção. Por sua vez, agentes indesejados são mantidos e ainda incentivados a práticas de expropriação ex post de forma a recuperar o esforço investido no processo de contratação.

Algumas manifestações decorrentes do cenário tratado acima são recorrentemente tratadas na literatura. Uma das mais abordadas na análise econômica de contratos é a presença de quase rendas expropriáveis (KLEIN et al., 1978).

Quase rendas estão relacionadas à capacidade de usos alternativos de um determinado ativo. Ativos com baixa especificidade de uso possuem uma maior reempregabilidade e, portanto, um maior valor de resgate caso o arranjo que tenha demandado seu investimento venha a falhar. No entanto, o aumento da especificidade de um ativo reduz tal valor de resgate, de forma que o mesmo tem menor valor em usos alternativos àquele para o qual foi inicialmente destinado.

Formalmente, quase rendas podem ser representadas como a diferença entre (i) o valor presente do fluxo de caixa gerado pelo ativo quando empregado na atividade que demandou seu investimento e (ii) o valor presente do fluxo de caixa obtido quando empregado em seu melhor alternativo (second best).

Quase rendas são expropriáveis quando uma das partes consegue exercer algum poder de barganha e capturar parte das mesmas. Por exemplo, considere-se um empreendedor que se engaja em uma relação investindo em um ativo cujo fluxo de caixa trazido a valor presente é $x$. A diferença entre este montante e aquele possível em second best é $\Delta x$.

Um comportamento oportunista pode ser suscitado se a contraparte contratual consegue agir de forma mal intencionada sem restrições. Este quadro de "liberdade de ação" pode se configurar devido a baixo nível de enforcement do contrato, seja por um desenho ineficiente do mesmo, seja por fraqueza do ambiente 
institucional (pouca proteção de direitos de propriedade). $\mathrm{O}$ agente pode buscar capturar parte de $\Delta x$ ameaçando renegar o contrato que demandou o investimento. Assumindo racionalidade do empreendedor, este cederá à barganha do agente, cedendo parte da quase renda até alcançar $\tau-\Delta x$. Em outras palavras, o empreendedor foi "capturado" pelo agente, um fenômeno tratado como holdup na literatura (WILLIAMSON, 1985, p. 31).

A proteção de quase rendas está relacionada à decisão de investir em ativos específicos, os quais estão associados a aspectos de eficiência em arranjos. Tradicionalmente, a integração vertical é proposta como meio de economizar nos custos de proteção contra expropriação de quase rendas de ativos especializados (KLEIN et al., 1978). Os autores revisitam e propõem o clássico caso General Motors/Fisher Body como exemplo de uso da integração vertical para eliminar o risco de holdup.

Apesar da preservação de quase rendas, o emprego de arranjos baseados na hierarquia gera algumas compensações indesejáveis do ponto de vista da firma. Problemas como rigidez organizacional, baixo nível de incentivos ao bom desempenho, necessidade de se investir em ativos não relacionados à atividade chave da organização, dentre outros têm sido elencados por diversas áreas do conhecimento para justificar a busca por arranjos alternativos à integração vertical.

Pesquisas anteriores têm indicado o surgimento e evolução de diversos mecanismos alternativos à integração vertical pura para mitigar o risco de holdup. Dentre os mais recorrentes estão o uso de reféns (hostages), com as partes investindo em garantias do tipo "sunk cost" ex ante (WILLIAMSON, 1996, p. 64; DNES, 2003); o investimento em reputação (BRICKLEY et al., 2006); ou ainda o investimento compartilhado em ativos específicos (MILGRON; ROBERTS, 1992, p. 307).

Outras manifestações de riscos comportamentais têm sido tratadas na literatura. Em coalizões produtivas, quando não é possível mensurar a contribuição individual com exatidão, toma forma o problema da realização privada dos ganhos versus a partilha dos custos decorrentes com os demais integrantes da coalizão (ALCHIAN; DEMSETZ, 1972). Uma vez que o custo de identificar problemas de 
conduta individual é alto em relação às economias esperadas, a organização tende realizar tal economia na remuneração do grupo como um todo.

Fama e Jensen (1983) sugerem dois métodos gerais e substitutos entre si para controlar o comportamento dos agentes: dispositivos de controle e a alocação de diretos residuais. O primeiro método busca limitar o poder decisório de agentes, enquanto o segundo aloca direitos residuais irrestritos aos agentes de decisão (propriedade do ativo). Neste caso, uma vez que os agentes suportam a maioria dos efeitos de suas ações, custos de agência são reduzidos.

Firmas proprietárias de marcas bem avaliadas pelo mercado tendem a não adotar versões mais extremas da segunda alternativa, na qual que cada agente local compra todos os direitos residuais de decisão para sua unidade (BRICKLEY; DARK, 1987). Problemas de externalidades entre unidades dentro da organização demandariam algum nível de controle central com intuito de preservar o valor de marca.

Um dos principais problemas enfrentados por empresas com marcas valiosas é controlar as ações dos agentes em toda a organização para assegurar o valor continuado da mesma. Nem todos os indivíduos dentro da empresa terão interesse em consumir esforços para manter a qualidade e reputação do produto. Serão elencados a seguir algumas fontes de externalidades negativas para as quais se espera que a rede consuma recursos no sentido de mitigá-las.

Independente do nível de detalhe do contrato entre as redes e seus franqueados, a ocorrência de fraudes pode ser de difícil detecção (BEALES; MURIS, 1995). Aspectos subjetivos da gestão diária da unidade como a coordenação local de funcionários ou mesmo a qualidade dos insumos locais podem alcançar níveis danosos ao empreendimento. Embora estas atividades sejam por vezes identificáveis, sua detecção sistemática pode ser proibitivamente custosa.

Uma vez que o nível de produtividade local não é totalmente observável, o agente pondera o nível de esforço que investe na relação. O agente pode moderar o nível de esforço que investe pelo montante de informação assimétrica que retém. Como resultado, haverá sempre uma fonte de ineficiência em unidades operadas como lojas próprias em relação às unidades franqueadas. Quanto mais dependente 
do esforço local for o sucesso da rede, mais onerosa será esta ineficiência (LAFONTAINE; BHATTACHARYYA, 1995).

A pesquisa relacionada ao setor de franquias indica a predominância deste arranjo nos setores de varejo e serviços (COMBS et al., 2011). Este formato organizacional gera relações contratuais com benefícios potenciais para todas as partes. O franqueador tem a oportunidade de construir sua rede de forma rápida, pois novos mercados passam a ostentar sua marca. $O$ franqueador aloca grande parte da tomada decisão local para os operadores das unidades, podendo se concentrar na gestão da rede. Além disso, ideias criativas dos franqueados, muitas vezes, ajudam franqueadores a otimizar processos e produtos. Por outro lado, pela perspectiva dos franqueados, eles obtêm oportunidades de simultaneamente possuir seu próprio negócio, porém operando sob um conceito de negócio já testado.

Brickley (1999) identifica na literatura de franchising inicialmente três correntes de pensamento que buscam explicar a adoção deste tipo de arranjo: captação de recursos, incentivos e auto seleção. A visão da captação de capital (recursos escassos) supõe que os lucros por unidade não dependem da propriedade. Nesta ótica franchising é visto como um meio de baixo custo para levantar capital para financiar novas unidades. A segunda corrente (oriunda da teoria da agência) enfatiza os trade-off entre incentivos aos gestores através de contratos de franquia versus contratos de trabalho. A terceira proposta, baseada no uso de contratos de franquia para atrair indivíduos com habilidades gerenciais, não alcançou o nível de proeminência na literatura de franquias.

Dois trabalhos seminais marcam o início de uma discussão mais formalizada quanto ao fenômeno franchising: Caves e Murphy (1976) e Rubin (1978). Curiosamente, estes trabalhos são ponto de partida para o embate das duas correntes mais tradicionais para explicar o arranjo: a teoria da agência e a teoria de recursos escassos (MICHAEL, 2003). Enquanto o primeiro formaliza a visão de que franqueados são alívio a restrições financeiras de jovens redes varejistas, o segundo refuta este argumento e propõe franchising como arranjo economizador de custos de agência (ou coordenação).

Como será visto adiante, não apenas a contraposição ou mesmo a combinação destas duas propostas permitiram aumentar o entendimento do 
fenômeno, como novas propostas surgiram analisando o sistema de franquias por perspectivas diferentes.

Combs et al. (2011) fazem uma síntese da pesquisa recente em franchising. São identificados quatro temas principais. O primeiro concentra-se sobre os antecedentes de franquia, ou seja, os determinantes da opção pelo arranjo. $O$ segundo tema se volta para as consequências da adoção da franchising. O terceiro tema engloba uma série de artigos recentes examinando moderadores potenciais de relações de franquia.

Coletivamente, estes três temas sugerem que a Figura 1 é uma representação adequada para captar o conteúdo da pesquisa recente. Um quarto tema, não representado na Figura 1, consiste e avanços recentes na pesquisa em torno da internacionalização de redes de franquia.

$\mathrm{Na}$ presente pesquisa serão enfatizadas as duas correntes mais proeminentes em estudos de franquias: teoria da agência e a teoria dos recursos escassos, doravante denominadas TA e TRE sucessivamente.

Figura 1 - Mapa Conceitual da Pesquisa em Franchising

(fonte: adaptado de Combs et al., 2011)

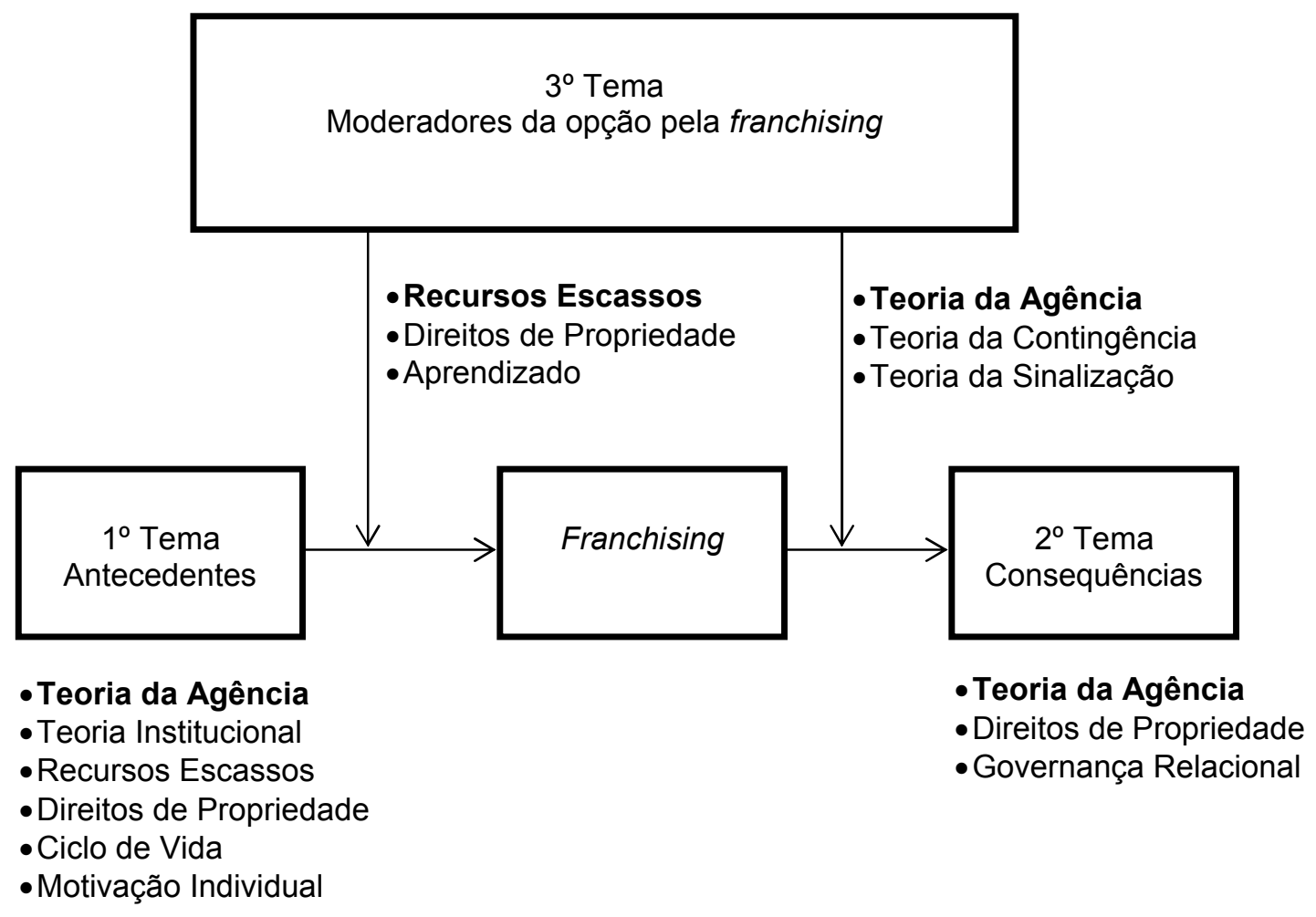




\subsection{Restrições ao Crescimento em Redes de Franquia}

Esse tópico é discutido principalmente em trabalhos ambientados na Teoria de Recursos Escassos (TRE). Para Caves e Murphy (1976) o financiamento das redes não teria substituto tão adequado quanto o capital fornecido por franqueados. Tal assertiva está no cerne da visão dos recursos escassos, a qual propõe o sistema de franquias como alternativa mais atraente para captação de recursos (COMBS; KETCHEN, 1999).

A explicação para franchising baseada na incapacidade de jovens redes em levantar capital é tradicional, não só entre os que advogam em favor desta corrente, mas também por practioneers de mercado (MICHAEL, 2003). Ou seja, as redes adotam o arranjo de franchising como alternativa relativamente mais barata para expandir suas operações (NORTON, 1995). As redes se beneficiariam com o aumento de receitas através de taxas de franquia, royalties e vendas para franqueados. Por outro lado (e principalmente), as redes também aliviariam a necessidade de empregar recursos próprios em sua expansão, visto que o investimento em ativos altamente específicos é em parte efetuado por franqueados.

Uma das principais consequências das hipóteses derivadas desta perspectiva seria a presença de um efeito ciclo de vida em franchising. Ou seja, redes de franquia adotariam fortemente mais unidades franqueadas durante a fase de expansão e, posteriormente, empregariam uma maior proporção de unidades próprias (uma inversão ao longo do ciclo de vida). Na medida em que a rede adquirisse porte e maturidade, uma menor dependência de recursos de franqueados seria necessária e o processo de expansão ocorreria com maior retenção da propriedade sobre as lojas. Não haveria venda de novas franquias e os contratos vigentes não seriam renovados. A proporção de lojas próprias cresceria.

Resultados de análises empíricas questionam fortemente esta perspectiva, tornando a TRE inicialmente bastante refutada na pesquisa em economia. Martin (1988) regrediu a proporção lojas próprias sobre tempo de adoção do modelo de franchising usando estimadores individuais para cada setor da indústria. Embora seus resultados suportem um pequeno, mas significante, efeito de reversão da proporção franqueada, o nível de reversão encontrado não é suficiente para pôr em dúvida a viabilidade no longo prazo do arranjo de franquias como uma alternativa 
organizacional. Provas para o efeito ciclo de vida não são um fato bem estabelecido (LAFONTAINE; KAUFMANN, 1994).

Por outro lado, Thompson (1994) analisa a relação entre a decisão de franquear e o crescimento em 200 redes de franquia nos EUA. Seus resultados indicam uma aceleração na taxa de crescimento das redes três vezes maior em comparação ao período em que operavam como firmas integradas. Na interpretação dos resultados, o autor argumenta que o uso de franquias contorna as limitações da firma em prover quadros gerenciais em ritmo suficiente para acompanhar o crescimento da rede; um fenômeno denominado "efeito Penrose".

O crescimento acelerado alivia a restrição da oferta de outros fatores de produção. Dois motivos são recorrentemente mencionados na literatura: alcançar escala mínima eficiente na promoção e publicidade da marca e conseguir proteger de expropriação ou imitação o conceito de processo/produto que sustenta o negócio (THOMPSON, 1994; AZOULAY; SHANE, 2001). Portanto, a exploração ótima do produto pode envolver a expansão rápida de forma a antecipar e desincentivar a entrada de concorrentes.

Como mencionado acima, existe uma perspectiva dinâmica da evolução das redes que não pode ser desconsiderado na explicação de franquias. Se estas fossem mera fonte de alavancagem financeira, seria esperado que o fenômeno fosse temporário (MARTIN, 1988). Isso não é comprovado empiricamente (NORTON, 1995). No entanto, os recursos providos por franqueados não estão restritos apenas à esfera financeira. Eles tendem a ter conhecimento do mercado local, capacidade administrativa e também capital. Não é possível dissociar nem desconsiderar estes potenciais (NORTON, 1988).

Em resumo, embora TRE ajude a explicar a opção inicial que uma firma faça em prol do arranjo de franquias, a reversão de propriedade para a firma prevista por esta teoria não ocorre (COMBS et al., 2004a).

Thompson (1994) foi um dos primeiros a operacionalizar os efeitos do ciclo de vida em redes de franquia. Ele identifica um padrão cúbico (um "S" horizontal) no comportamento do mix contratual ao longo do tempo, o que, aliás, parece conciliar as visões de TRE e TA. Ou seja, um aumento inicial na proporção de lojas franqueadas suporta o crescimento das redes nos primeiros anos. Em seguida, 
algum ajuste é gerado, com a rede adquirindo ou readquirindo lojas mais lucrativas. Por fim, a rede ajusta o mix contratual visando contornar ou controlar problemas de coordenação.

O setor de franquias é heterogêneo e as estratégias utilizadas para atração de novos franqueados tende variar bastante entre as redes (BORDONABA-JUSTE et al., 2010). A evidência empírica sugere que as estratégias podem variar durante o ciclo de vida da indústria, principalmente com relação a taxas de franquia e mix contratual (SHANE et al., 2006).

Neste ponto uma distinção precisa ser enfatizada. Trabalhos abordando o ciclo de vida das redes, como Thompson (1994), analisam o histórico de existência da rede, verificando como o mix contratual se comporta desde o surgimento até a maturidade. Por outro lado, trabalhos como Bordonaba-Juste et al. (2010) analisam o ciclo de vida da indústria, verificando o período em que determinada rede passa a integrar o setor ${ }^{7}$.

Trabalhos voltados para efeitos do ciclo de vida da indústria verificam os efeitos do momento de entrada das redes no setor. Por exemplo, dada a menor experiência típica de jovens entrantes, espera-se que mecanismos mais rígidos de controle sejam adotados, dentre eles um maior nível de controle hierárquico obtido através de cláusulas contratuais e mecanismos de monitoramento (BORDONABAJUSTE et al.,2010).

Na medida em que ganha maturidade, a rede tende a aumentar a proporção franqueada. Já em redes maduras uma relativa estabilidade do mix contratual é esperada (CLIQUET, 2000; LAFONTAINE; SHAW, 2005). Os primeiros participantes têm uma estrutura de propriedade consolidada enquanto jovens entrantes estão ainda na fase da atração de franqueados (THOMPSON, 1994).

Influências do estágio do ciclo de vida sobre taxas fixas de franquia e royalties também são esperadas. Redes maduras acumularam maior experiência com relação ao arranjo, rotinas e gestão de tarefas, oferecendo um maior produto marginal (também denominado insumo do franqueador) na relação com franqueados.

${ }^{7}$ Existem também outras vertentes denominadas ciclo de vida. Por exemplo, Frazer (2001) e Blut et al. (2011) baseiam seus modelos na teoria do ciclo de vida tradicional, com relações continuadas em uma sequência de estágios. Essa abordagem divide o desenvolvimento da relação em fases distintas: (i) de formação, (ii) de exploração, (iii), maturidade e (iv) rescisão. 
Além disso, considerando o porte tipicamente maior, maiores níveis de complexidade em gestão de rede do ponto de vista do franqueador o levaria a exigir um maior nível de compensação para continuar a gerir a rede (SHANE, 1996). Sob tal perspectiva, as firmas que entraram nos primórdios da indústria devem apresentar relação positiva entre taxa de royalties e o tamanho da rede, enquanto o oposto é válido para jovens entrantes.

\subsection{Mecanismos de Incentivo e Coordenação}

Estes aspectos são tipicamente discutidos pela Teoria da Agência (TA). Relações de agência estão presentes sempre que uma parte - o principal - delega autoridade a uma segunda - o agente (EISENHARDT, 1989). Uma vez que as partes muitas vezes possuem objetivos divergentes, o principal deve monitorar ou oferecer incentivos a agentes, com intuito de induzi-los a se comportarem o no melhor interesse do principal (JENSEN; MECKLING, 1976).

O trabalho seminal de Rubin (1978) foi o primeiro a discutir franchising como uma forma de economizar custos de agência ${ }^{8}$. O autor rompe com a tradicional visão de franqueados como fonte de capital barato. Sua alternativa decorre diretamente dos trabalhos de Alchian e Demsetz (1972) e Jensen e Meckling (1976) sobre monitoramento e controle. Se o monitoramento das unidades é vital para o sucesso da rede e, simultaneamente, torna-se proibitivamente oneroso com o aumento da dispersão e quantidade de unidades, um formato organizacional baseado em incentivos passa a ser uma alternativa viável. O sistema de franquias, o qual torna a remuneração do agente vinculada ao sucesso da unidade, surge como opção de arranjo (PRICE, 2000).

A característica crucial da propriedade de unidades locais próprias é que esses estabelecimentos são geridos por gestores assalariados que não suportam totalmente os custos das suas decisões (NORTON, 1995). Assim, pouco esforço e benefícios derivados em excesso podem ocorrer de forma que os custos de monitoramento dos proprietários tendem a ser mais elevados do que em soluções

${ }^{8}$ Custos de agência estão presentes em qualquer transação entre indivíduos (JENSEN e MECKLING, 1976). Estes custos são definidos como os custos de monitoramento do esforço do agente, as despesas com incentivo ao alinhamento de interesses e a perda residual decorrente, ou seja, as perdas geradas por não ser possível se alcançar o alinhamento total de interesses na relação agente-principal. 
alternativas, principalmente quando a dispersão espacial dos estabelecimentos ou a natureza do produto ou da transação também aumentam os custos de monitoramento.

Ao adotar o modelo de franquias, o proprietário da rede cede parte do resíduo da operação de forma a criar mecanismos de controle capazes de evitar o comportamento inadequado e subinvestimento de esforços (shirking) por parte do agente local.

Na perspectiva da teoria da agência as vantagens comparativas do sistema de franquias como arranjo organizacional não decorrem da provisão de capital financeiro de baixo custo. A vantagem obtida estaria no estabelecimento de uma estrutura de incentivos capaz de economizar em custos de monitoramento (RUBIN, 1978).

Em geral, franqueados investem parte substancial de sua riqueza em uma única unidade. Isso vincula a compensação do agente ao desempenho da unidade. Ceteris paribus, melhores níveis de desempenho resultarão em mais renda para franqueados e mais royalties para franqueadores.

O franqueado tem duplo incentivo para maximizar as receitas através de uma gestão eficaz e da promoção do conceito de franquia, minimizando os custos variáveis. O franqueador tem incentivos em promover vendas brutas através do fortalecimento da marca, o que eleva o montante de royalties e, consequentemente, sua compensação. Por conseguinte, a necessidade de monitoramento é reduzida na medida em que o esforço do franqueado é auto imposto (FLADMOE-LINDQUIST; JACQUE, 1995).

A essência dos acordos de franquia sob esta perspectiva está na estruturação de incentivos que alinham o comportamento do franqueado (KLEIN; SAFT, 1985). Em um contexto de balanceamento entre custos de agência, algum nível de monitoramento é substituído por incentivos: cede-se parte do resíduo ao agente local (RUBIN, 1978). O agente deixa de ser um gerente contratado para assumir o status de reclamante residual da unidade (MICHAEL, 2000b).

Alguns autores propõe que, sob a perspectiva da teoria da agência, sob certas circunstâncias, os clientes podem exercer o papel de substitutos para o monitoramento direto do desempenho das unidades (PRICE, 2000). Ou seja, em 
situações onde o consumidor realiza transações de forma recorrente em determinada loja da rede, sendo atraído e retido pelos atributos do produto gerado naquela unidade.

Quedas no nível de serviço reduziriam a carteira de clientes, sinalizando uma possível queda de desempenho da unidade. Isso está em consonância com a análise seminal de Rubin (1978), para o qual unidades estabelecidas em regiões rurais distantes de grandes centros tendem a ser franqueadas.

Toda sua compensação e parte substancial de sua riqueza pessoal estão agora vinculadas ao desempenho da loja. Se a unidade opera de forma eficiente em condições satisfatórias de demanda, uma maior renda é gerada para o franqueado e um maior fluxo de royalties é destinado ao franqueador.

Em suma, franchising é um híbrido entre mercado e hierarquia para controlando relações de agência (ou seja, dispositivos de controle e propriedade residual) (BRICKLEY; DARK, 1987). Apesar do status de reclamante residual, o franqueado não tem direitos totais de decisão, pois alguns destes direitos são retidos pelo franqueador (ponto comercial, cardápio, projetos arquitetônicos e/ou prediais, horas de funcionamento, etc.).

A relação entre dispersão geográfica e franchising é consideravelmente suportada por estudos empíricos. Combs e Ketchen (2003) relacionam uma série de artigos testando a hipótese da dispersão geográfica em TA, mas em alguns setores esse não é propriamente o caso. Por exemplo, cadeias de supermercados são comumente dispersas. Se o monitoramento do esforço e da dispersão geográfica dos estabelecimentos são determinantes essenciais da franchising, redes de supermercados franqueadas deveriam ser comuns, quando na verdade quase todas as grandes cadeias de supermercados estão integradas (MANESS, 1996).

Segundo Maness (1996) o diferencial entre estes setores está no papel do agente local ante a gestão de custos da unidade. No gerenciamento de empreendimentos como supermercados as grandes contas de custos estão concentradas em torno de estoques e logística, cuja gestão é notadamente centralizada. Ou seja, segundo a visão do autor a propriedade é mais eficiente alocada a quem melhor gerencia custos locais. 
Brown (1998) também questiona a dispersão geográfica como principal limitação na propriedade de unidades de produção. $O$ uso de franquias constituiria um alívio sobre a incapacidade das firmas em motivar todos os seus gerentes com relação à perspectiva de carreira. Ou seja, dada a estrutura piramidal da hierarquia, não é possível acomodar todos os gerentes em cargos mais elevados, de forma que o pacote de incentivos se deprecia com o passar dos anos. Ao adotar o modelo de franquias, o sucesso do gestor local pode ser premiado com a concessão de novas unidades.

O regime de compensação de franqueados provê incentivos para incrementar a qualidade do insumo investido no nível local. São exemplos do insumo do franqueado o treinamento e monitoramento de funcionários, atendimento de clientes, manutenção do nível especificado de qualidade, algum nível de publicidade local, dentre outros (BRICKLEY, 1999). No entanto, a partilha do resíduo (e de riscos) entre franqueador e franqueados não é suficiente para garantir o pleno esforço dos agentes.

\subsection{Taxas Fixas de Franquia e Taxas de Royalties}

Em contratos típicos de franchising o franqueado paga uma taxa fixa inicial e não reembolsável, além de um fluxo contínuo de royalties, normalmente um percentual sobre vendas brutas (WIMMER; GAREN, 1997). Em contrapartida o franqueado recebe o lucro residual de sua unidade (o total de vendas líquido de impostos menos os custos operacionais, incluindo o pagamento de royalties) (BRICKLEY, 2002).

Não são muitos os modelos propostos em franchising com implicações dinâmicas diretas sobre os termos financeiros de contratos de franquia. Dentre ao mais mencionados na literatura aparecem o modelo de sinalização de Gallini e Lutz (1992) e o modelo de reputação de Mathewson e Winter (1985), os quais implicam que os franqueadores reduzirão as suas taxas de royalties e aumentarão suas taxas fixas de franquia ao longo do tempo ${ }^{9}$.

\footnotetext{
${ }^{9}$ No modelo de sinalização de Gallini e Lutz (1992) o franqueador tem informação privada sobre o valor da sua marca, o qual tenta comunicar a potenciais franqueados. Em equilíbrio, marcas de sucesso conseguem sinalizar a qualidade de sua proposta de valor praticando taxas mais altas ou
} 
Royalties são, normalmente, baseados em vendas ao invés de lucros. Uma explicação para isso é o fato de que, para o franqueador, é mais fácil monitorar e documentar vendas brutas do que lucros, os quais podem ser afetados por alocação de arbitrária de custos e despesas, por exemplo (BRICKLEY, 2002).

Explicações pioneiras de franquias propunham o pagamento da taxa fixa inicial de franquia como o fluxo descontado estimado do lucro da unidade trazido a valor presente. Assim, pagamentos contínuos de royalties variáveis seriam um desmembramento da taxa fixa inicial, o qual teria a função de ajustar riscos, conferindo um maior fluxo do resíduo para franqueador em épocas de melhor condição da demanda e evitando que franqueados suportem sozinhos o fracasso de uma operação (RUBIN, 1978). Por outro lado, conforme o autor, uma explicação alternativa para royalties pode ser derivada do mercado de capitais: franqueados podem, a princípio, não ter recursos para pagar integralmente e de uma só vez o valor presente dos ganhos da unidade, de forma que este pagamento seria distribuído ao longo do tempo.

No entanto, uma explicação mais plausível parece ter relação com os incentivos de parte a parte presentes. Assim como o franqueador espera bom desempenho de franqueados, estes esperam uma gestão eficiente do franqueador no sentido de maximizar o valor da rede (orientação, publicidade, promoção, etc.). Isso seria particularmente verdadeiro com relação ao valor da marca (reputação e externalidade). O pagamento de royalties, então, incentivaria o franqueador a manter os padrões desejados em toda a rede, executando as tarefas relacionadas.

A visão tradicional de TA para a relação entre royalties e taxas fixas de franquia propõe antagonismos entre ambas em um contexto bilateral de risco moral e necessidades de incentivos. Se o produto marginal do franqueado é relativamente elevado, afetando mais as condições de demanda local, então, o franqueador pratica royalties menores de forma a manter o operador local motivado pela maior retenção do resíduo (lucro) de sua unidade. Em compensação as taxas fixas iniciais cobradas

operando diretamente uma maior proporção de lojas próprias. Na medida em que a informação sobre a qualidade da proposta de valor fosse revelada, menores taxas seriam praticadas e mais franqueados seriam atraídos. Esse modelo não recebeu suporte empírico (LAFONTAINE, 1992).

O modelo de reputação de Mathewson e Winter (1985) indica que as taxas se elevam na medida em que a marca do franqueador acumula valor. Isso implica a formação de filas de franqueados atraídos pela reputação da marca. 
são maiores (LAFONTAINE, 1992; BHATTACHARYYA; LAFONTAINE, 1995; HUANG, 1997).

O oposto é válido em situações onde a marca é valiosa e importante para a demanda da rede. Isso significa que a demanda é mais dependente do comportamento do franqueador no monitoramento do desempenho de outros franqueados, a fim de evitar a desvalorização da marca. Este processo implica que, uma vez que a demanda depende fortemente do valor da marca, o risco do franqueado seria relativamente menor. Assim, o franqueador reduz as taxas fixas iniciais para atrair um maior número de franqueados potenciais, mas praticas royalties maiores ao longo do contrato (HUANG, 1997).

Propostas mais recentes têm associado o comportamento destas taxas a aspectos intangíveis como o valor a marca da proposta de valor das redes. Para atrair e motivar franqueados, as redes precisam definir suas taxas fixas de franquia em um nível apropriado ao valor de sua marca e dos serviços que prestam aos seus franqueados. Normalmente, redes jovens no início de sua operação tendem a ter sua marca subdesenvolvida e serviços disponíveis a franqueados relativamente limitados (SHANE et al., 2006). Nestas circunstâncias, as taxas praticadas tendem a ser mais baixas.

No entanto, Shane (2006) não consegue suportar estas hipóteses com relação às taxas variáveis. Royalties dependeriam do valor da proposta de valor do formato de negócios oferecido pelas redes aos franqueados, de tal forma que poderiam proporcionar um sinal de crível da qualidade e afetar a atratividade geral do sistema (SHANE et al., 2006). Com a maturidade, a taxa praticada de royalties tenderia a cair, vis-à-vis a perda do ímpeto inicial dos primeiros anos da rede e seu formato de negócios, o esgotamento e/ou saturação do mercado. Além disso, semelhante ao que ocorre em relações trabalhistas, a maior familiaridade dos franqueados com o dia a dia de sua(s) unidade(s) aumenta os custos do fim do relacionamento para as redes, condicionando-os assim a demandar uma maior parcela do resíduo de suas unidades.

Uma visão oposta à descrita imediatamente acima é confirmada em pesquisas como Polo-Redondo et al. (2011). Com a maturidade, a reputação e o valor da marca tendem a acumular, repercutindo sobre o valor das taxas de franquia. 
Além disso, um contexto de equilíbrio entre elas é previsto. Vasquez (2005) analisa a relação entre royalties e taxas fixas de franquia no setor de franquias na Espanha, identificando um balanceamento entre estas taxas. Diferentemente de trabalhos anteriores, ele considera na taxa variável o lucro obtido pelas redes com a venda (compulsória ou não) de insumos a franqueados. Segundo o autor, muitas vezes o preço de venda destes insumos superam seu custo marginal caracterizando transferência de renda de franqueados para franqueadores.

Assim, em um contexto de risco moral bilateral e alocação ótima de risco, elevações no montante de risco fazem decrescer as taxas fixas e aumentarem os royalties praticados (incluindo lucro sobre insumos fornecidos) ${ }^{10}$. Esse comportamento das taxas também ocorre se o insumo do franqueador é mais complexo (promoção da marca, coordenação da cadeia, etc.) e de difícil verificação por franqueados. Por outro lado, o oposto é valido para cenários onde tanto o esforço do franqueado e como o monitoramento de seu desempenho cresce em importância para o sucesso da rede.

Por fim, as visões mais recentes resumem o papel dos royalties como fonte de aporte ao trabalho contínuo do franqueador em incrementar o varo da rede, ao passo que a taxa fixa de franquia sustentaria investimentos iniciais do franqueador antes da abertura da loja (POLO-REDONDO et al., 2011). Assim ambas as taxas variaram juntas no sentido de se elevarem na medida em que a reputação e o valor da marca fossem acumulados. A visão de risco moral bilateral persiste na pesquisa mais recente, ou seja, as taxas variarão para beneficiar a parte que mais agrega valor a marca (MURUYAMA; YAMASHITA, 2011). Uma vez que esta mesma pesquisa aponta para um papel mais efetivo do franqueador neste sentido, esperase que ambas as taxas, fixa e variável, aumentem ao longo do ciclo de vida das redes.

\subsection{Riscos Comportamentais do Franqueado}

A literatura em TA indica algumas recorrências em termos de manifestações de problemas de agência. Embora reduzidos pelo incremento de incentivos (como ocorre em franquias), estes problemas não são eliminados porque algum nível de

\footnotetext{
${ }^{10}$ Infelizmente, para a presente pesquisa, dados como estes não estão disponíveis.
} 
desalinhamento persistirá. Assim, algum nível de monitoramento e controle é esperado, assim somo de garantias e/ou compensações disponibilizadas para permitir a contratação.

Problemas de seleção adversa aumentam na medida em que a rede cresce de forma acelerada (NORTON; 1988). A administração da rede precisa diferenciar agentes qualificados daqueles indesejados (LEVINTHAL, 1988). Informações necessárias para tomar essas decisões passam a ser demandadas com mais intensidade, o que eleva o custo de evitar o problema de seleção adversa (PRESCOTT; VISSCHER, 1980).

Uma segunda recorrência em termos de problemas de agência em relações de franquia tem a ver com a influência do risco moral, seja ele unilateral (franqueado) ou bilateral (franqueado-franqueador). Agente e principal escolhem suas ações de forma a maximizar o seu próprio retorno na contratação (LUTZ, 1995). Se as cláusulas contratuais fortalecem incentivos para ao franqueador, ela tende a enfraquecer os do gerente local, e vice-versa. Tanto contratos de franquia como os trabalhistas são afetados pelo problema de risco moral.

Em contratos de franquia, apesar da redução na necessidade de monitoramento decorrente de aumento de incentivos entre as partes, alguns problemas verticais de agência permanecem. Como não é possível alinhar inventivos plenamente, persiste o potencial para o comportamento oportunista nos dois lados da relação. A literatura em economia trata este fenômeno como risco moral bilateral (LAFONTAINE, 1992).

Uma vez que o franqueador normalmente reserva a si o direito de rescindir antecipadamente o contrato como forma de controlar o risco moral de franqueados, um quadro de risco moral do franqueador se forma uma vez que o mesmo pode tentar expropriar quase rendas de investimentos específicos de franqueados (BRICKLEY; DARK, 1987).

Storholm e Scheuing (1994) elencam várias possibilidades de oportunismo bilateral. Os franqueadores podem dispor lojas geograficamente muito próximas, rescindir precocemente o contrato a fim de reabrir a unidade como loja própria no mesmo local, forçar franqueados a comprar seus insumos, apropriar indevidamente 
a taxa de publicidade, e desenhar contratos que lhe beneficie em caso de litígio judicial futuro.

Por sua vez, franqueados podem afetar negativamente o franqueador divulgando informações proprietárias, deixando de pagar royalties ou ainda não aderindo a padrões de qualidade.

O problema de free-riding ${ }^{11}$ tem a ver com incentivos ao oportunismo que ocorrem no contexto de múltiplos indivíduos operando sob uma marca comum. Sob tais condições, cada franqueado pode reduzir o montante de insumos investidos, reduzindo também a qualidade do produto que oferece e partilhando com o restante de rede as consequências desta ação. A dinâmica decorrente do problema de freeriding é o efeito da redução da qualidade percebida entre consumidores, com consequentes externalidades negativas sendo transmitidas para as demais unidades da rede.

Este problema é mais provável em situações onde os consumidores não impõem disciplina suficiente sobre o comerciante, sendo estas situações mais comuns em contexto de consumidores transeuntes ou não recorrentes (BRICKLEY; DARK, 1987; KLEIN, 1995; HUANG, 1997) 12.

O aspecto essencial de um acordo de distribuição via franquia está na criação de um produto padronizado, uma vez que a padronização cria informações valiosas para o consumidor. Padrões levam o consumidor a realizar os atributos que denotam o produto, de modo que tais atributos são esperados em qualquer unidade da rede que ele venha a ter experiência de consumo (KLEIN; SAFT, 1985). O consumidor espera que o franqueador padronize e controle a qualidade através dos pontos de venda e está disposto a pagar um preço por este serviço.

Se cada franqueado fornece insumos que influenciam significativamente a qualidade do produto comercializado e os consumidores não podem detectar a qualidade do produto antes de comprá-lo, então cada franqueado terá o incentivo para reduzir custos e ofertar uma qualidade do produto menor do que o nível desejado. Como o produto é padronizado, os consumidores que recebem produtos

11 "Pegar carona", na tradução literal.

${ }^{12}$ Por exemplo, Brickley e Dark (1987) verificam que o fenômeno franchising é menos comum em três setores onde o problema do free-riding é potencialmente maior: hotéis e motéis, restaurantes e locadoras de veículos. 
de qualidade inferior à prevista culpará toda a rede. O franqueado individual se beneficia diretamente da venda do produto de qualidade inferior e os demais franqueados partilham as perdas causadas pela diminuição da demanda futura. A literatura econômica denomina adversidades deste tipo como o problema de freeriding, pois o franqueado está literalmente "pegando carona" na reputação da marca (MICHAEL, 2000a).

Segundo Klein e Saft (1985) não há irracionalidade por parte do consumidor ao reagir à piora da qualidade de uma determinada unidade da rede quando o mesmo reduz ou cessa suas compras nas demais. Eles estão reagindo adequadamente ao pobre trabalho de monitoramento feito pelo franqueador, com o qual eles têm de certo modo implicitamente contratado, o monitoramento da qualidade do produto.

Lafontaine e Slade (1996) analisam a literatura de free-riding e encontram evidências contraditórias sobre seu efeito em redes de franquia. Segundo as autoras uma explicação para a falta de evidências conclusivas é o fato de franqueadores encontrarem formas de controlar o comportamento do franqueado como, por exemplo, utilizar restrições quanto a fornecedores de matérias primas. Em um nível vertical, o franqueador tem geralmente a responsabilidade primordial do desenvolvimento de marca, devendo impedir o free-riding por parte dos franqueados que podem não oferecer o nível de produto no padrão de qualidade característico da marca (HENNESSY, 2003).

A literatura prevê ainda a influência de custos de mensuração da formatação de arranjos. Estes custos estão relacionados ao delineamento dos atributos que caracterizam determinado produto (BARZEL, 1982). Por exemplo, a contratação de fornecimento de uma commodity (como minério de ferro, por exemplo) tem atributos cujo delineamento pode ser considerado mais objetivo: propriedades físico-químicas do material, peso/volume, prazo de entrega, dentre outras cuja contratação é mais bem estabelecida do ponto de vista da cessão de direitos de propriedade.

No entanto, muitas das transações observadas no cotidiano lidam com bens e serviços cujos atributos são subjetivos ou cujas características contratadas ex ante somente podem ser confirmadas durante ou após a experiência do consumo (BARZEL, 1997, p.94). Tal condição contribui para elevação potencial do risco moral 
na transação, uma vez que a informação tende a se distribuir assimetricamente na relação, uma vez que o consumidor não consegue antecipar os atributos do produto até que o mesmo seja recebido e/ou consumido.

Em um contexto de arranjos de governança e organização da produção, espera-se que variações em custos de mensuração influenciem na formatação destes arranjos. Ou seja, assumindo racionalidade dos players de mercado, esperase encontrar arranjos se aproximando da integração vertical quando o objeto de contratação apresentar custos de mensuração mais elevados, com um nível de controle mais acentuado por parte da gestão das redes (leiam-se direitos de decisão).

\subsection{Padronização}

Relações de franquia são caracterizadas por uma tensa dualidade entre a necessidade de padronização no nível de rede e a conveniência da adaptação a mercados locais (COX; MASON, 2007). Por um lado, produtos e serviços padronizados estão no cerne da proposta de valor de redes franqueadas. Por outro, a autonomia de franqueados é um importante apelo à proposta de "ser o seu próprio patrão" oferecida pelas redes de franquia (DANT; GUNDLACH, 1999). De fato, a análise empírica indica que franqueadores não são tão propensos a tolerar desvios dos padrões estipulados em seus contratos, o que significa que os franqueados não lidam com muita margem para iniciativas próprias (MICHAEL, 1996a).

Normalização e uniformidade são pilares do conceito franquias. Há três razões para isso, segundo Kaufmann e Eroglu (1999). Em primeiro lugar, a padronização é um meio de alcançar a minimização de custos para o franqueador e franqueados, notadamente em termos economias de escala obtidas em compras de insumos e promoção da marca. Além disso, a padronização reduz custos do monitoramento de franqueados.

Em segundo lugar, a padronização permite que o conceito possa ser comunicado de forma consistente ao longo da rede, a fim de construir e manter uma imagem distinta entre os clientes. Esta imagem uniforme proporciona um modelo de identidade que faz com que os clientes da rede esperem receber o mesmo produto em todas as unidades (FALBE; DANDRIDGE, 1992; MICHAEL, 2002). Uniformidade 
e consistência são, portanto, imperativos para atrair e reter clientes e manter a integridade da proposta de valor da marca (DANDRIDGE; FALBE, 1994; MICHAEL, 1996; PRICE, 1997). Isso cria interdependência entre as unidades do sistema (COX; MASON, 2007). Construir e manter uma imagem uniforme do conceito ao longo do sistema é, portanto, fundamental, pois cada franqueado tem um impacto potencial sobre os demais (KAUFMANN; DANT, 1999). Se franqueados desviam-se do modelo padrão em busca de seu próprio interesse, aumenta a probabilidade de erosão e deterioração da qualidade da marca.

Por fim, as práticas de adaptação local podem reduzir a capacidade do sistema de inovar. O conhecimento gerado por franqueados individuais pode ser de pouco valor para outros franqueados que operam em ambientes diferentes. Mais importante, se os franqueados se adaptam excessivamente às condições locais, ocorre um descasamento entre suas rotinas operacionais em relação ao do restante do sistema, o que reduz o potencial de geração de ideias de valor para a rede como um todo (KAUFMANN; EROGLU, 1999; SORENSON; SØRENSEN, 2001).

Kaufmann e Eroglu (1999) argumentam que a padronização é fundamental nas fases iniciais da rede a fim de projetar um conjunto relativamente grande de elementos comuns a todas as lojas. Mesmo pequenas diferenças poderiam interferir na capacidade dos consumidores generalizarem sua expectativa de consumo.

Na medida em que as redes amadurecem, a necessidade de padronização pode diminuir. Não só a rede amadurece, mas também o setor em que atua. $O$ ambiente de negócios provavelmente se torna mais competitivo, de forma que, para se manter neste ambiente, a rede precisa de uma postura mais empreendedora por parte de franqueados sob a forma de experimentação e inovação (TUUNANEN; HYRSKY, 2001).

O termo padronização remete (e algumas vezes se funde) ao conceito de replicação, e ambos são recorrentes na análise do arranjo de franchising. Replicação implica em criação e operação de um grande número de estabelecimentos similares entregando um produto com alto grau de padronização. Este arranjo, inicialmente disseminado a partir do ramo de redes de restaurantes em sido aplicado por empresas em inúmeras indústrias. No início dos anos 2000 cerca 
de 1/3 das vendas no varejo dos EUA ocorriam em organizações em rede (WINTER; SZULANSKI, 1995; SZULANSKI; JENSEN, 2008).

Padrões transmitem mais facilmente a informação sobre o conjunto de atributos que caracterizam o produto transacionado, independentemente do arranjo empregado para realizar a transação. Consequentemente, quanto maior o grau de padronização presente, menores serão os custos de mensuração destes atributos.

Por exemplo, Brownell e Merchant (1990) verificam a relação entre automação e padronização de produto com o controle orçamentário. Pesquisando empresas do setor de componentes eletrônicos, os autores concluem elevados níveis de automação em processos e padronização de produtos o processo de orçamentação é mais preciso.

A dinâmica da replicação normalmente é concebida como a aplicação repetida de uma fórmula ou receita simples, porém inovadora e encaixada em uma necessidade específica de um grupo de consumidores. O pressuposto é que a fórmula é perfeitamente conhecida pelo replicador e reproduzida com precisão cada vez que a replicação ocorre.

No entanto, apesar da concepção relativamente simples, o empreendimento de modelos baseados em replicação apresenta aspectos de relativa complexidade (WINTER; SZULANSKI, 1995). A criação de valor pela replicação inicia-se através da descoberta e refinamento de um modelo de negócios baseado em um produto ou processo inovador, com posterior seleção dos componentes necessários para replicar esse modelo em diferentes localizações geográficas e diferentes contextos mercadológicos. Cria-se valor ainda desenvolvendo-se capacidades para "rotinizar" a transferência de conhecimento e manter o modelo em funcionamento. Longe de ser um pacote de informações instantaneamente absorvidas e processadas, normalmente trata-se de um complexo conjunto de rotinas interdependentes, o qual é identificado, ajustado e afinado pela experiência à frente da rede.

A expansão através da replicação de uma fórmula deriva da capacidade de recriar processos produtivos complexos, muitas vezes não totalmente compreendidos e em parte tácitos, com diferentes recursos humanos e enfrentando por vezes a resistência de agentes com relativa autonomia, dado o potencial de 
assimetria de informação gerado pela própria dinâmica de expansão do negócio (SZULANSKI; JENSEN, 2008).

Este raciocínio se aproxima do próprio conceito de franchising enquanto formato de negócios, o qual apresenta entre suas características mais notáveis o desenvolvimento de um modelo diferenciado de prestação de serviço que ocorre muito próximo ao consumidor final. Redes com maior êxito conseguem replicar tal serviço em um grande número de unidades geograficamente dispersas (COMBS et al., 2004a).

O presente estudo entende que o nível máximo de replicação que pode ser obtido por uma rede ocorre quando suas unidades meramente comercializam produtos acabados. A razão alegada para este pressuposto é a não ocorrência de processos de transformação no nível de loja.

Do ponto de vista de uma rede varejista com múltiplas unidades, espera-se que redes cujas unidades simplesmente repassam ao consumidor final um produto já totalmente acabado tendam a lidar com maiores níveis de padronização, potencializando monitoramento e mensuração de resultados. Para estas redes a atenção sobre as unidades está mais centrada em questões relativas ao atendimento, layout de loja, etc.

Por fim, mesmo em redes com alto grau de processamento de produtos ocorrendo no interior das unidades, a questão da padronização é alavancada por maiores níveis de automação. Com a ação humana sendo substituída por equipamentos e sistemas computadorizados o produto tende a ser gerado de forma mais uniforme e parametrizada. Ou seja, com maior grau de padronização (BROWNELL; MERCHANT, 1990).

No nível de loja, a presença de processos mais automatizados e/ou sistematizados potencialmente eleva a capacidade de monitorar a distância. Como colocado por Norton (1988), máquinas não tentam 'fugir' do trabalho. No entanto, pessoas podem ser tentadas a ludibriar, entregando menos esforço do que foi contratado. Para um determinado nível de produção, custos de monitoramento se elevarão com o aumento da intensidade do trabalho. 


\subsection{Automação e Monitoramento ${ }^{13}$}

A dispersão de lojas em redes de franquia potencializa custos de monitoramento em função da distancia entre lojas. Esse raciocínio está no cerne da discussão de franquias, quando abordada pela Teoria da Agência (RUBIN, 1978). O monitoramento busca romper o quadro de maior a assimetria informacional com relação ao esforço investido pelo operador local. Fosse o monitoramento eficiente no sentido de custo/benefício, então, pela Teoria da Agência, poderia se esperar que franchising fosse um fenômeno menos recorrente.

Poucos trabalhos anteriores se voltaram para o papel da automação em contratos de franquias. Uma das exceções é dissertação de mestrado que precede a presente pesquisa (BITTI, 2007). Nesta, é verificado que maiores níveis de automação (aproximado pela razão entre área de loja e o número de funcionários) influenciam na retenção da propriedade de uma maior proporção de lojas próprias pela rede.

A Figura 2 ilustra a decisão de mix contratual no contexto vertical dos custos de agência (ou seja, a decisão de franquear ou não). No gráfico, a padronização dos processos ao nível de loja, no tempo, é mantida constante. A eficiência dos esforços de monitoramento (eixo vertical) significa o montante de perdas residuais que o incremento de uma unidade monetária de monitoramento consegue mitigar. $\mathrm{O}$ eixo horizontal representa o nível de dispersão das lojas.

Duas curvas são esboçadas para representar dois pacotes distintos de incentivos: "menor incentivo" (gerente assalariado) e "maior incentivo" (franqueado). Assume-se que a remuneração do gerente de uma loja própria é fixa e configura um pacote de incentivos inferior ao do status de reclamante residual proporcionado pela franquia. O eixo horizontal representa a dispersão das lojas.

\footnotetext{
${ }^{13}$ Esta seção deriva da pesquisa de mestrado (BITTI, 2007) que precedeu o presente estudo.
} 
Figura 2 - Custos de Monitoramento vs. Arranjo [fonte: adaptado de Bitti (2007)]

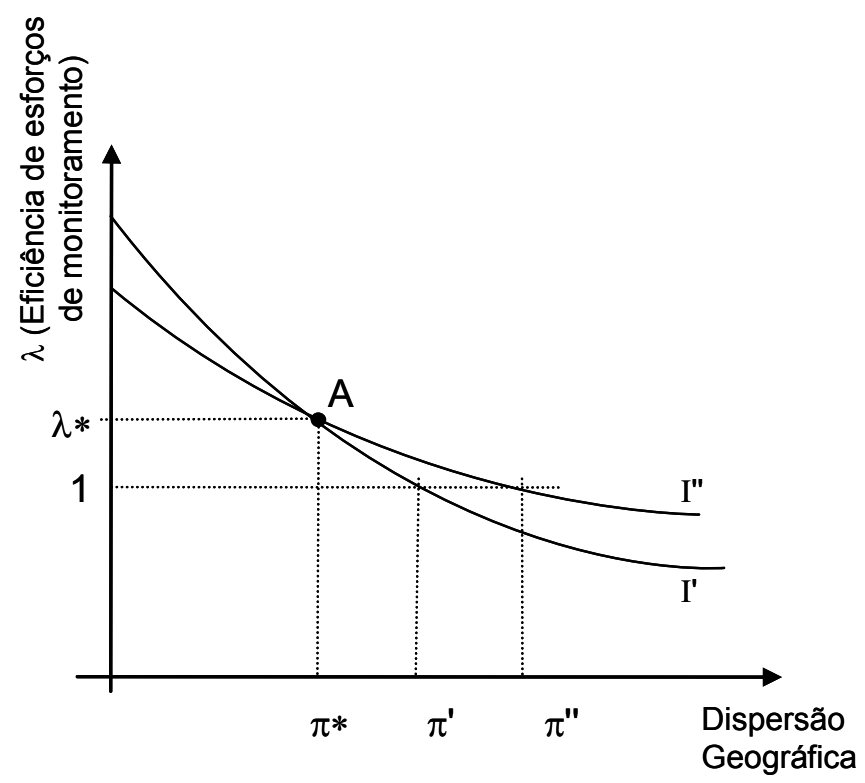

A origem do eixo horizontal (dispersão zero) considera a rede com apenas uma loja. Ou seja, se a loja é própria, assume-se que o proprietário da unidade exerce monitoramento presencial por estar ele mesmo à frente das operações da loja. Por outro lado, se a rede inicia suas operações com apenas uma unidade já franqueada, haverá custos de monitoramento positivos pelo fato do proprietário necessitar acompanhar o comportamento do agente (um franqueado) à distância.

No eixo vertical observa-se o ponto onde a eficiência de monitoramento se iguala a um $(\lambda=1)$, em que, para cada unidade monetária acrescida em monitoramento a perda residual é reduzida também em uma unidade. Neste ponto não existe nenhum ganho em redução de perda residual com o monitoramento; e abaixo deste ponto entra-se em uma zona de ineficiência $(\lambda<1)$.

A curva $I^{\prime}$ representa a queda da eficiência do monitoramento com o aumento da dispersão para uma rede que mantivesse a propriedade sobre suas lojas (gerentes contratados). O ponto $\pi^{\prime}$ indica o momento onde esta rede não consegue obter eficiência na redução de perdas residuais com o monitoramento.

A curva $I^{\prime \prime}$, por sua vez, representa a mesma situação para uma rede que apresenta um pacote maior de incentivos ao agente desde sua primeira loja. O ponto A é o ponto de indiferença, em que $\pi^{*}$ e $\lambda^{*}$ são os mesmos para ambos os níveis de incentivos. Até o ponto $A\left(\pi<\pi^{*}\right)$ as duas curvas apresentam eficiência em redução da perda residual maior que um $(\lambda>1)$. Entretanto, o arranjo com menores 
incentivos consegue mitigar mais a perda residual para uma mesma dispersão das lojas.

A partir do ponto $A\left(\pi>\pi^{*}\right)$, o arranjo com maiores incentivos (curva $I^{\prime \prime}$ ) passa a ser mais eficiente em reduzir a perda residual quando comparado ao arranjo de menores incentivos (curva $I^{\prime}$ ).

De forma mais realista, o ponto $A$ caracteriza um ponto de rotação para a curva $I^{\prime}$. Assumindo racionalidade por parte da rede, espera-se que neste ponto, confrontando os ganhos possíveis de eficiência em monitoramento para uma dada dispersão, a rede opta pelo arranjo de maiores incentivos. Ao estabelecer um arranjo com maiores incentivos, a rede rotaciona a curva $I^{\prime}$ no sentido anti-horário até alcançar o formato da curva $I^{\prime \prime 14}$. Assim, a partir do ponto de rotação, a rede não só usufrui de maior eficiência na redução da perda residual, como também aumenta o limite em que a dispersão geográfica destrói sua eficiência de monitoramento $\left(\pi^{\prime \prime}>\pi^{\prime}\right)$.

A diferença entre $\pi^{\prime}$ e $\pi^{\prime \prime}$ é o quanto a rede pode acrescer de dispersão mantendo $\lambda>1$, ou seja, mantendo esforços de monitoramento eficientes na redução de perda residual. Com $\lambda \leq 1$, qualquer unidade monetária de monitoramento colocada não recupera seu equivalente em termos de redução da perda residual.

Em qualquer situação além de $\pi$ " para $I^{\prime \prime}$ (franquia), o proprietário da rede assume as perdas residuais não mitigadas pelos esforços de monitoramento. A partir deste ponto não se esperaria a ocorrência de qualquer arranjo, a menos que as motivações da rede fossem outras como a criação de barreiras de entrada, por exemplo (HADFIELD, 1991).

A tecnologia de monitoramento ou o grau de padronização/automação ao nível de loja difere entre indústrias e mesmo entre redes, sendo consequência de variáveis como tipo de negócio, porte ou maturidade. Em função disso, considera-se ainda que a rotação da curva $I^{\prime}$ pode ser influenciada pela capacidade técnica de

${ }^{14}$ Este trabalho leva em conta as conclusões de Lafontaine e Shaw (1999), as quais verificam que os contratos de franquia possuem um formato homogêneo entre franqueados. Ou seja, uma vez assumida a opção da rede pela franquia, os termos dos contratos não se alteram entre os diversos franqueados. Assim, a curva I" pode sumarizar o arranjo franquia. 
monitoramento de lojas entre as redes. Para cada rede, existe hipoteticamente um melhor arranjo na decisão de mitigação de perdas residuais, na Figura 2.

Espera-se que maiores níveis de automação nas lojas de uma rede proporcionem uma menor variabilidade na qualidade esperada do produto final, bem como uma aferição mais eficiente do consumo de recursos e montante de vendas. Ou seja, uma redução da incerteza sobre o output das lojas. A necessidade da exatidão destas informações explicaria, por exemplo, a ausência de franquias de confecção de produtos artesanais, pelo menos nas redes verificadas para este estudo.

A Figura 3 ilustra o efeito moderador da automação. As mesmas curvas representando incentivos $I^{\prime}$ e $I^{\prime \prime}$ da Figura 2 são novamente traçadas. Entretanto, a curva tracejada I*, representando um maior nível de automação, desloca o ponto de indiferença (ou ponto de rotação) para a direita - agora o ponto B. Isso significa que a rede pode manter a propriedade das lojas mesmo com uma maior dispersão geográfica.

Figura 3 - Efeito Moderador da Automação [fonte: adaptado de Bitti (2007)]

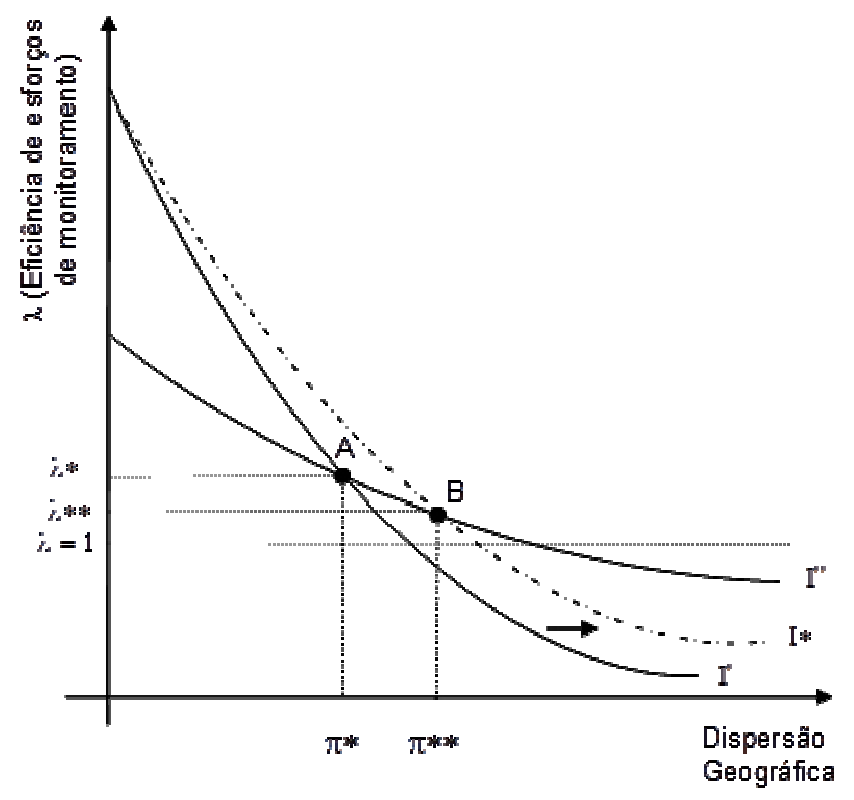

Em outras palavras, a presença de um maior nível de automação mantém níveis aceitáveis de eficiência $(\lambda>1)$ em maiores níveis de dispersão geográfica $\left(\pi^{* *}\right)$, postergando a necessidade de se intensificar os incentivos ao agente (franquia). 
O comportamento da curva $I^{*}$ é determinado tanto pelo padrão tecnológico característico do setor (diferença entre indústrias), quanto pelo incremento tecnológico proporcionado pelo investimento da rede. Na medida em que a mesma cresce em porte e maturidade, espera-se que as restrições de investimento neste sentido sejam aliviadas, e tecnologias em processos de produção e monitoramento sejam alcançadas (deslocando a curva $I^{*}$ para a direita).

A pesquisa relacionando sistemas de informação e sociologia sugere quando estes mecanismos são aplicados na firma e entre firmas (em um contexto interorganizacional), permite-se controlar o comportamento à distância e com número reduzido de supervisores (BOULAY, 2010). Este tipo de controle fortalece a coordenação, proporcionando um acompanhamento mais eficiente, reduzindo o tempo e custos envolvidos na coleta de dados e automatizando a própria análise destes dados (SIA et al., 2002;. SEWELL; WILKINSON, 1992).

Ao tornar as atividades desempenhadas mais transparentes, sistemas de informação exercem um efeito disciplinador. Agentes sob a presunção do monitoramento tendem a agir em conformidade com o que acham ser esperados pelo principal (BOULAY, 2010). Este efeito "panóptico" foi observado por Grover et al. (2002) em estudo visando estabelecer como sistemas de informação podem ser usados para aumentar o controle sobre comportamentos oportunistas em relações de fornecimento.

É possível aproximar o efeito relativo da automação entre as redes com base na relação entre mão de obra e área alocada nas unidades. Ou seja, se para uma mesma área de trabalho um número menor de pessoas é demandado para condução das operações, espera-se pela presença de processos mais automatizados, com o esforço humano sendo substituído por algum tipo de sistema ou dispositivo.

Simultaneamente, independente do nível de automação, quanto menos processos de transformação ocorrer no interior das unidades, menos complexa é a informação demandada a partir das mesmas para fins de controle.

No limite, em caso de lojas que meramente comercializam produtos recebidos das redes, a informação necessária refere-se apenas ao montante de produtos 
vendidos, além de questões como a padronização de atendimento e fachada de loja, por exemplo. Ou seja, em casos como este o risco de ruído na informação é menor.

Assim como o nível de automação, o nível de processamento nas lojas influencia a qualidade da informação. Por sua vez, a qualidade da informação presente afeta o formato do arranjo, aproximando (ou afastando) o desenho dos contratos da integração vertical.

\subsection{Suporte ao Franqueado como Controle}

Problemas de controle em redes de franquia podem surgir, por exemplo, da incerteza quanto ao acatamento de padrões de referência, os quais proporcionam monitoramento e mensuração de desempenho de operadores locais em mercados heterogêneos (CAMPBELL et al., 2009). Além disso, a presença das unidades da rede em localidades diversas, com uma base de clientes diversificada, encontrará dificuldades em atender simultaneamente e demandas tão distintas de maneira uniforme preservando a integridade de sua marca (ANDERSON; MITTAL, 2000; BRADACH 1997; CHASE, 1983).

As redes podem aliviar esses problemas de controle limitando sua expansão a tipos relativamente uniformes de mercados ou delegando poderes de decisão e criando de incentivos para os operadores locais (BAIMAN et al., 1995). Neste aspecto, o modelo de franquias parece atender plenamente a segunda alternativa.

O desafio fundamental para o franqueador é alcançar uma "previsibilidade controlada" (COX; MASON, 2007), o que garantiria a qualidade esperada e representada pela marca, tanto em relação aos atributos do produto como em relação às rotinas características do formato de negócios.

A transmissão de procedimentos e práticas através de treinamento e suportes de ordem operacional molda rotinas da unidade em resposta ao feedback do ambiente e de experiências passadas da rede. De acordo com essa perspectiva, as redes podem ser beneficiar através do compartilhamento de rotinas e conhecimentos através de suas unidades (ARGOTE et al., 1990).

Trabalhos anteriores tratam o suporte concedido pelos franqueadores como um investimento a ser recuperado na forma taxas cobradas de franqueados 
(LAFONTAINE, 1992, WIMMER; GAREN, 1997; BORDONABA-JUSTE et al., 2010).No entanto, argumenta-se que é razoável o emprego destes procedimento como forma de educar franqueados e desenvolver um canal de comunicação com informação sem ruído entre aas unidades e o franqueador.

Por exemplo, Michael (2000b) verifica que franqueadores utilizam o treinamento de franqueados como forma de aumentar o nível de dependência destes. Como resultado, aumenta o poder de barganha da rede em renegociações futuras e reduzem-se o número de litígios entre as redes e seus franqueados.

Assim, em um contexto de controle, franqueadores fornecem diretrizes operacionais, políticas, procedimentos e suporte de marketing. Por sua vez, franqueados devem seguir essas diretrizes e fornecer ao franqueador informações precisas e oportunas sobre vendas e resultados (PASWAN; WITTMANN, 2009). Embora a tecnologia da informação tenha impacto sobre o nível de assimetria de informação ao longo da rede (Seção 3.6), a principal ferramenta para o controle são os mecanismos contratuais que induzem $O$ franqueado a conhecimento $e$ informações com o franqueador (DARR et al., 1995). Neste aspecto, o estreitamento da relação propiciado pelo suporte contínuo parece ser um conveniente artefato de interação.

\subsection{Comportamento Estratégico no Ciclo de Vida}

É necessário inicialmente definir o conceito de estratégia de forma a validar a ligação deste construto com a presente análise. O construto estratégia na literatura de teoria organizacional aplicada a escolhas estratégicas nem sempre está claramente definido, possuindo diversas vertentes (VENKATRAMAN; GRANT, 1983). Na revisão feita por estes autores, algumas operacionalizações do construto seguem o conceito de estratégia como tomada decisão deliberada (ex ante); outras seguem o conceito de estratégia como diversificação; e um terceiro grupo de operacionalizações segue o conceito de postura estratégica (por exemplo, as estratégias genéricas de Porter).

Atendendo a recomendação de Venkatraman e Grant (1983) por uma clara definição de estratégia, entende-se que a construção de redes de franquia é um processo interativo que, ao longo do tempo, gera dependência do caminho (path 
dependence ${ }^{15}$ ). Cada decisão deliberada que a rede implanta altera sua posição no mercado em relação a: (i) proposta de valor ao cliente, (ii) proposta de negócio ao franqueados, (iii) reputação e conceito da marca, (iv) mix contratual (proporção de lojas próprias e franqueadas). O conjunto destas decisões eleva a especificidade dos ativos envolvidos nos quatro elementos citados, o que eleva o custo de mudança de posições (shift barriers).

Portanto, a definição de estratégia aqui adotada é menos associada a decisões pontuais e mais associada ao conjunto de escolhas feitas pela rede ao longo de seu ciclo de vida. Estas escolhas são em parte respostas, adaptações que a rede faz ao mercado, as quais podem ser observadas na variação do mix contratual, nível de dispersão, perfil de ocupação, dentre outros, os quais permitem identificar perfis de comportamento entre as redes e, por conseguinte, grupos de comportamento estratégico cujos traços característicos são resultados de um processo histórico.

Assim sendo, define-se aqui estratégia como o caminho percorrido pela rede decorrente de um conjunto de escolhas feitas ao longo do tempo como resposta a variações nas condições de mercado, relacionamento com fornecedores e necessidade de equilibrar a proposta de valor oferecida a franqueados e aos clientes finais de seus produtos. Assim a estratégia é uma descrição do comportamento da rede ao longo do seu ciclo de vida. Tais escolhas se apresentam nas características do contrato de franquia, nos investimentos em treinamento de funcionários de franqueados, desenvolvimento de tecnologia, entrada em certos tipos de mercados, escolha da família de produtos, dentre outros. Na medida em que aciona as decisões tomadas, um conjunto de investimentos com elevado nível de especificidade é efetuado, elevando custos para reorientações abruptas.

Pesquisas recentes na literatura de franchising têm se voltado para estratégias como variáveis moderadoras do desempenho das redes (COMBS et al.,

15 O conceito de path dependence surgiu inicialmente em discussões sobre o papel da inovação na economia. Mais especificamente, na análise da presença de rendimentos crescentes a partir da escolha de um determinado padrão tecnológico, Tais rendimentos crescentes potencializam a probabilidade de lock-in, ou seja, um cenário onde o padrão tecnológico vigente gera elevados custos de mudança em relação a novas e mais eficientes tecnologias (FIANI, 2002). Posteriormente, autores como Douglass North estenderam a discussão de path dependence à nova abordagem institucional, a qual propõe que para o processo evolutivo de instituições, é necessário entender o paradigma tecnológico a elas associado (NORTH, 1990, p. 95). 
2011). Nesta literatura, três elementos são recorrentemente indicados como moderadores do desempenho das redes: (i) proposta de valor a franqueados, (ii) mix contratual e (iii) momento de entrada no segmento (entry-timing).

O primeiro elemento tem a ver com a política de preços e atratividade a franqueados. Em franchising existem dois tipos de consumidores para as redes: os clientes finais do produto final e os clientes do formato do negócio - os franqueados (POLO-REDONDO et al., 2011). A escolha do pacote de preços para atrair franqueados pode ser analisada através dos termos do contrato relacionado com a taxa de royalties e a taxa fixa inicial.

Embora relacionadas à remuneração do insumo do franqueador, a estruturação de taxas pagas pelos franqueados é utilizada por redes de franquia para conseguir maior controle sobre o canal de distribuição (SEN, 1993). Uma vez que também há evidências de que redes maiores e mais maduras conseguem praticar taxas maiores (BORDONABA-JUSTE, 2010), parece haver uma distinção em que franqueadores mais jovens (menos capital reputacional acumulado) praticam taxas mais baixas visando atrair franqueados, enquanto os mais bem estabelecidos ajustam estas taxas para compensar aspectos de reputação e gestão de rede.

O segundo elemento recorrentemente mencionado em estudos de estratégia em franquia é o mix contratual. Com base na teoria da contingência, Yin e Zajac (2004) analisam como a escolha do mix contratual influencia o desempenho de redes de franquia. Unidades franqueadas tendem a apresentar estruturas mais flexíveis e descentralizadas, sendo mais apropriadas em contextos de maior complexidade na operação (por exemplo, lanchonetes multisserviço, com consumo local e delivery disponíveis). Por outro lado, lojas próprias apresentaram um melhor desempenho quando o modelo de operação local requer processos mais simples. Essa evidência vincula disposição do mix contratual à estratégia de redes ao empregar pacotes de incentivos diferentes (contratos de franquia versus contratação de funcionários) a níveis diferentes de mensuração e monitoramento.

A pesquisa em torno da estratégia de mix contratual indica outras aplicações além da questão da comparabilidade e mensuração. Sorenson e Sorensen (2001) identificam que lojas próprias são usadas pelas redes para consolidar rotinas já existentes nos processos da rede, enquanto franqueados são mais uteis em 
aspectos de inovação. Composições típicas de mix contratual também podem atender as necessidades de geração de informação sem ruído. Kidwell e Nygaard (2004) sugerem que franqueadores utilizam dados de demanda vendas em lojas próprias para parametrizar o desempenho de franqueados, inibindo problemas de free-riding e baixo esforço. Por outro lado, o desempenho de franqueados é utilizado para pressionar gerentes de unidades próprias, cujos incentivos são menos efetivos.

Por fim, o terceiro elemento mencionado relaciona-se com o ciclo de vida da indústria e o timing de entrada da rede. Vantagens do pioneirismo ${ }^{16}$ de redes de franquia na ocupação de mercados justificam o desejo de rápido crescimento (MICHAEL, 2003). Ou seja, existem provavelmente vantagens em ser o primeiro a ocupar mercados onde concorre. Em setores como varejo e alimentação (tipicamente ocupados por redes franqueadas), a localização é um moderador importante do desempenho da firma, de modo que as redes se engajariam na preempção de imóveis bem posicionados. Em segundo lugar, os primeiros a ocupar mercados podem moldar as preferências dos consumidores. Com isso, um prêmio é alcançado por redes de rápido crescimento.

Para Combs e Ketchen (2003), a discussão das vantagens obtidas por redes pioneiras resgata a relevância da discussão baseada na teoria dos recursos escassos (TRE). Como já mencionado, hipóteses baseadas nesta vertente receberam inicialmente pouco suporte da literatura empírica. De fato, a definição de franqueados sumarizada em um provedor de recursos de baixo custo levaria a esperar o sistema de franquias como fenômeno temporário do ponto de vista da firma. No entanto, os argumentos da TRE adquirem coerência na medida em que se admitem as vantagens do pioneirismo, ou seja, levantar rapidamente os recursos necessários para adotar a estratégia de antecipar movimentos de ocupação de espaços (MICHAEL, 2003, POLO-REDONDO et al., 2011).

Ou seja, redes jovens e com pouco acesso a recursos fundamentais para o crescimento podem contornar tais restrições alavancando recursos de franqueados. Assim, em um espaço de tempo bem menor, estas redes poderiam ocupar uma maior quantidade de pontos, alcançar escala mínima eficiente em compras e promoção da marca, além de recursos gerenciais na figura de franqueados.

\footnotetext{
${ }^{16}$ Equivalente ao "first-mover" nos termos de Lieberman e Montgomery (1988).
} 
As primeiras pesquisas em franquias relacionaram a dinâmica do porte ao longo do tempo inicialmente pela perspectiva do ciclo de vida das redes (HUNT, 1973; LILLIS et al., 1976) e mais tarde pela perspectiva dos recursos escassos (CARNEY, GEDAJLOVIC, 1991) e respostas a problemas de coordenação (CASTROGIOVANNI et al., 2006). Mais recentemente, as abordagens têm considerado aspectos do ciclo de vida da indústria nos diversos setores ocupados por redes franqueadas (POLO-REDONDO et al., 2011).

Com relação ao ciclo de vida das redes, existem recorrências e similaridades no comportamento das redes, de forma que é possível encontrar alguns grupos de comportamento (SEN, 1998). Dadas as similaridades entre atributos observáveis, é possível operacionalizar estas formações como grupos estratégicos, como verificado em Carney e Gedajlovic (1991), Combs et al. (2004b), Martinez-Torres e Toral-Marin (2010), dentre outros.

Portanto, é possível vincular grupos estratégicos a um contexto de ciclo de vida. No momento em que a rede adere ao sistema de franquia, a rede procura atrair franqueados com intuito de crescer o mais rápido possível, contornando naturais restrições nos primeiros anos da operação e obtendo escala mínima eficiente em atividades como compra de insumos e promoção da marca. Com o tempo e ganho de porte, este ritmo tende a cair, com a rede ajustando o mix contratual conforme orientações táticas em resposta a condições de demanda, ou ainda para contornar problemas de coordenação.

A Figura 4 esboça as curvas relacionadas ao porte (linha cheia), proporção de lojas franqueadas (linha tracejada) e especificidade de ativos (linha pontilhada) ao longo do tempo. Assumindo uma rede típica que inicia usa operação com uma única loja própria e que passa a se expandir adotando o arranjo de franquias em $T_{1}$. Entre $T_{1}$ a $T_{2}$ a rede a rede investe na atração de franqueados, possivelmente praticando taxas mais baixas neste sentido.

A partir de $T_{2}$ a reputação da rede é suficiente para atrair um maior número de franqueados, de forma que a mesma busca crescer o mais rápido possível através da atração de franqueados. O número total de unidades é influenciado pelo aumento do número de franquias vendidas. Esta fase envolve forte adaptação da rede aos mercados locais onde se instala. Ativos envolvidos na operação, tais como a marca, 
maquinário e mobília tornam-se específicos sob a influência dessa fase. Isso é válido para a especificidade de ativos humana, com rotinas e tipos de treinamento evoluindo de forma idiossincrática às necessidades e oportunidades desenvolvidas ao longo do caminho.

Figura 4 - Ciclo de Vida (fonte: elaborado pelo autor)

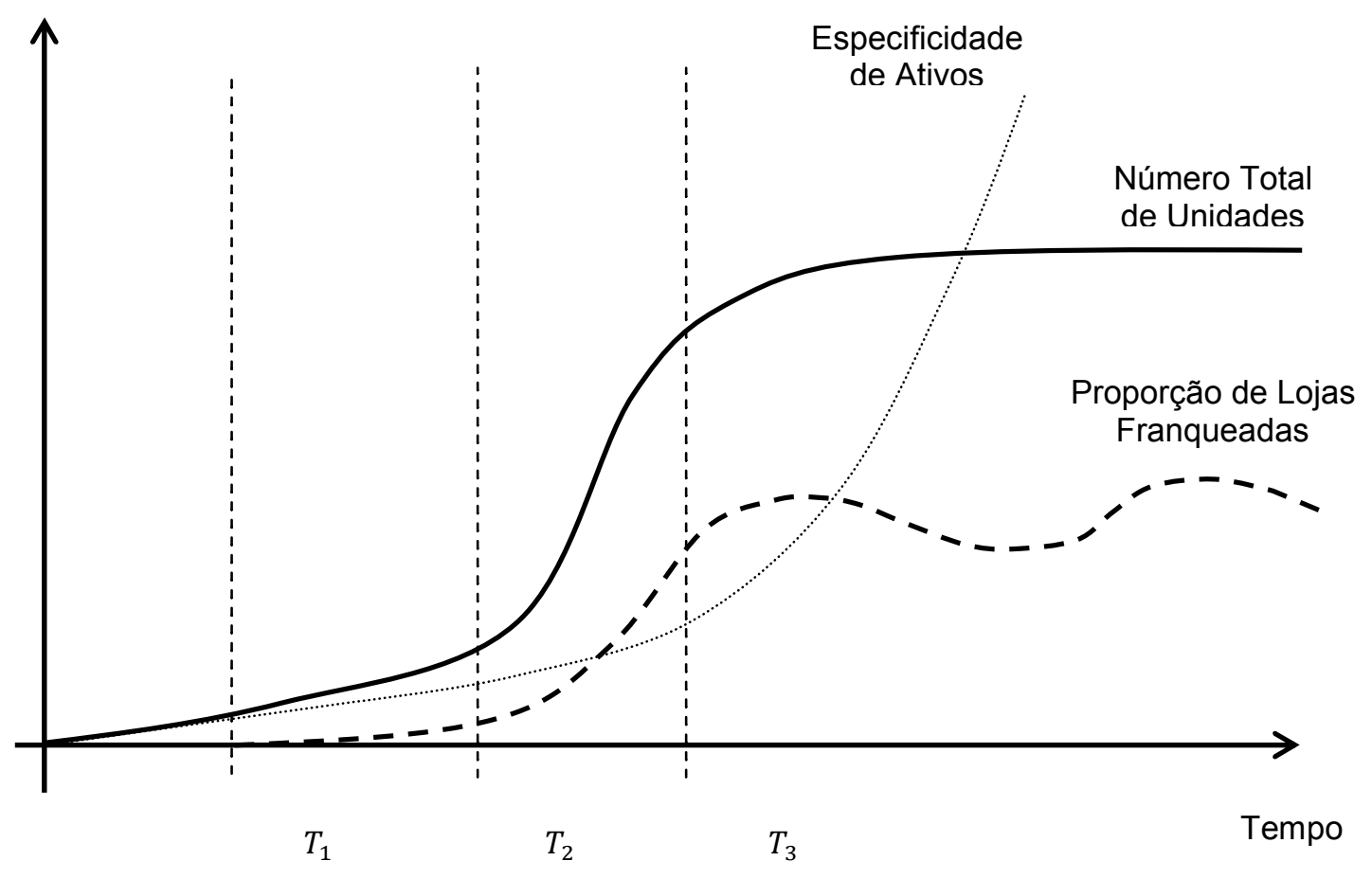

Entre $T_{2}$ e $T_{3}$, a rede acumula experiência, desenvolve operações e fortalece a marca. O padrão cúbico da variação do mix contratual (CASTROGIOVANNI et al., 2006) passa a se tronar visível, com a rede utilizando o conhecimento acumulado para identificar oportunidades de abertura de lojas próprias, ou mesmo de converter algumas lojas franqueadas em lojas próprias. O oposto é válido para contornar problemas de incentivos a operadora local, o que demandaria a conversão de gerentes contratados em franqueados.

Nesta fase, o nível de especificidade de ativos já é elevado, por exemplo, a troca de um pacote tecnológico escolhido ao longo do trajeto envolve mudanças em centenas de pontos de operação, bem como treinamento e adaptação ao novo processo. Isto é consequência das experiências da rede ao longo da trajetória. Maiores alterações de rota quanto à estratégia já implicam perdas. Assim, alterações 
são marginais, gerando um reforço da estratégia vigente. A própria política de atração de franqueados não é tão flexível. Contratos de franquia têm duração média de 60 meses, e grandes alterações trariam insatisfação e questionamento do quadro atual de franqueados. Ainda assim, a rede contempla oportunidades de ocupação de novos mercados, possibilitando o emprego de customizações.

Por fim, a partir de $T_{3}$, a rede lida com elevado nível de especificidade de seus ativos. Em função da necessidade de padronização, atributo fundamental do arranjo de franquias, uma alteração na identidade destes ativos é proibitiva ou, no mínimo, inviável (daí o formato da curva). Por exemplo, a rede pode ter uma alta proporção de lojas operando em shopping centers, afetando custos de saída.

O mix contratual continua sendo ajustado conforme necessidade da rede em lidar com custos de coordenação. Por exemplo, avanços na tecnologia de monitoramento podem permitir à rede supervisionar unidades à distância, minimizando a necessidade de mecanismos de incentivos.

Por fim, a partir de $T_{3}$ a rede já se aproximou do ponto de exaustão dos mercados para seu produto. A partir daqui o crescimento é possível é dado por alterações nas condições gerais de demanda como, por exemplo, o surgimento de mercados alternativos em regiões que antes não eram atraentes para a rede.

Em síntese, ao longo da trajetória, ativos específicos - físicos e humanos são desenvolvidos em um processo interativo e decorrente da trajetória. Ao mesmo tempo em que decorre do ciclo de vida, a especificidade direciona a trajetória futura da rede, tornando difícil grandes alterações no modelo de negócios.

\subsection{Grupos Estratégicos}

Como previamente mencionado, a literatura indica a ocorrência de grupos de redes com comportamento similar com relação ao ciclo de vida (SEN, 1998) os quais apresentam comportamentos e resultados distintos entre si (MARTÍNEZ-TORRES; TORAL-MARIN, 2009).

Nesta pesquisa definem-se grupos estratégicos como conjuntos de empresas (redes de franquia) com histórico similar. Ou seja, uma definição diversa daquela 
vista em Porter (1986, p. 133), para o qual grupos estratégicos seriam conjuntos de firmas com perfis competitivos similares.

Os elementos constituintes destes grupos podem ser classificados em torno de características principais, tais como estratégia e estrutura, as quais são frutos do processo interativo destas redes com seu ambiente ao longo de seu ciclo de vida. Na perspectiva da pesquisa em Administração Estratégica,

As firmas relacionadas a estes grupos reúnem conjuntos semelhantes de variáveis estratégicas específicas (PEREIRA-MOLINER et al., 2010), o que não significa que eles devam apresentar desempenhos idênticos (COMBS et al., 2004b), uma vez que provavelmente diferiram em relação a recursos, competências ou capacidades (MCNAMARA et al., 2003).

Um aspecto importante afeta estes grupos. A todo instante, novas oportunidades de lucro potencial podem tornar algumas estratégias mais interessantes do que outras. As empresas podem ser tentadas a mudar seu comportamento para aproveitar estas oportunidades. No entanto, as barreiras de mudanças já mencionadas na Seção 3.8 podem tornar proibitivo o movimento da firma de um grupo para outro, tanto pela ótica do risco como pelos sacrifícios financeiros necessários. Assim, as empresas normalmente optam por não mudar de grupo, uma vez que não está claro se os ganhos desempenho obtidos excederão os custos incorridos (COMBS et al., 2004b). Como resultado, os grupos estratégicos com perfis mais lucrativos devem superar aqueles com perfis menos ajustados às demandas ambientais. Esta teoria foi suportada em Ketchen et al. (1997), os quais identificam características de determinados grupos explicam diferenças de desempenho entre as firmas.

Embora alguns trabalhos já tenham identificando a presença de grupos estratégicos no setor de franquias (CARNEY; GEDAJLOVIC, 1991; CASTROGIOVANNI et al., 1995; CATALUÑA et al., 2007; MARTÍNEZ-TORRES; TORAL-MARIN, 2010), o primeiro investiga as diferenças de desempenho potenciais entre franqueadores decorrente da associação a grupos estratégicos foi Combs et al. (2004b), para os quais a composição de propostas teóricas entre TA e TRE permitida na abordagem de grupos estratégicos proporciona conclusões plausíveis quanto aos desempenho de redes de franquia. 
Martínez-Torres e Toral-Marin (2010) mencionam as três principais vertentes teóricas voltadas para a formação de grupos estratégicos: organização industrial, estratégia e perspectivas cognitivo-comportamentais. $\mathrm{Na}$ linha da organização industrial, os grupos estratégicos são delineados com base em características persistentes da estrutura da indústria, as quais são resultantes de barreiras de mobilidade. Nesta visão as empresas podem ter incentivos para alterar o curso de sua estratégia para aproveitar oportunidades, mas custos de mudança inibem alterações de rota (CAVES; PORTER, 1977).

A pesquisa em estratégia enfatiza o ambiente interno às firmas, assumindo assim que a tomada de decisão busca configurar recursos internos de modo a estabelecer vantagens competitivas sustentáveis. Por fim, a perspectiva cognitiva afirma que os grupos estratégicos são formados por gestores que particionam seu ambiente para reduzir a incerteza e que possuem racionalidade limitada (PETERAF; SHANLEY, 1997).

A análise de grupos estratégicos permite comparabilidade entre a posição competitiva de cada empresa do setor em relação aos seus concorrentes (CATALUÑA et al., 2007). Portanto, o estudo e análise dos grupos estratégicos em um setor auxiliam o entendimento de sua estrutura, bem como a dinâmica da concorrência e da evolução do próprio sector.

Nath e Gruca (1997) alertam para a importância das variáveis empregadas no processo de identificação dos grupos. Ou seja, tais variáveis devem estar relacionadas à estratégia da organização, não podendo, por exemplo, ser modificadas no curto prazo (barreiras de mobilidade). Sua modificação significaria incorrer em custos de mudança elevados. Se essa condição não é respeitada a identificação de grupos estratégicos dentro de um setor fica comprometida.

Assim, grupos estratégicos podem e são aqui considerados como grupos de organizações separados por barreiras de mobilidade, as quais determinam seu comportamento competitivo. Tais barreiras são uma das razões para a explicação de diferenças com relação ao desempenho dos diferentes grupos estratégicos (LEE et al., 2002). 


\subsection{Síntese da Literatura em Franchising}

Para um quadro geral do estado da arte na pesquisa subjacente, algumas revisões de literaturas estão disponíveis. Combs e Ketchen (2003) aplicam uma meta-análise sobre 44 trabalhos empíricos que testavam hipóteses de TA e TRE relacionadas à opção pelo arranjo de franquias. O Quadro 1 resume as hipóteses e indica os resultados da meta-análise.

Quadro 1 - Hipóteses Recorrentes na Pesquisa em TA e TRE [fonte: adaptado de Combs e Ketchen (2003)]

\begin{tabular}{|c|c|c|c|c|}
\hline Teoria & Hipóteses & Construto & $\begin{array}{l}\text { Relação } \\
\text { Esperada }\end{array}$ & $\begin{array}{c}\text { Resultado } \\
\text { Meta-Análise }\end{array}$ \\
\hline \multirow{4}{*}{ TRE } & $\overline{\mathrm{H}_{1}}$ & Idade & - & Não Suportada \\
\hline & $\mathrm{H}_{2}$ & Porte & - & Não Suportada \\
\hline & $\mathrm{H}_{3}$ & Crescimento da Rede & + & Não Suportada \\
\hline & $\mathrm{H}_{4}$ & Escassez de Capital & + & Não Suportada \\
\hline \multirow{6}{*}{ TA } & $\overline{\mathrm{H}_{5}}$ & Dispersão Geográfica & + & Suportada \\
\hline & $\mathrm{H}_{6}$ & Conhecimento do Mercado Local & + & Suportada \\
\hline & $\mathrm{H}_{7}$ & Insumo do Franqueador & - & Suportada \\
\hline & $\mathrm{H}_{8}$ & Taxas Fixas & - & Não Suportada \\
\hline & $\mathrm{H}_{9}$ & Royalties & + & Não Suportada \\
\hline & $\mathrm{H}_{10}$ & Tamanho da Loja & - & Suportada \\
\hline
\end{tabular}

Combs et al. (2004a) fazem um levantamento da pesquisa em TA e TRE, buscando oportunidades de composição das duas perspectivas, além de relacionalas a outras vertentes teóricas (teoria dos escalões superiores, visão baseada em recursos e teoria institucional). Os autores ainda propõem 11 hipóteses testáveis a partir dessa composição entre propostas.

Combs et al. (2011) identificam temas recorrentes na pesquisa empírica recente. Os autores documentam a literatura recente e propõem uma agenda com base em algumas lacunas identificadas. Por exemplo, são notados poucos trabalhos nas áreas de Contabilidade, Operations Management, Ética em Negócios, Recursos Humanos e Comportamento Organizacional. Além disso, os autores ainda sugerem a inserção de áreas como o Direito, a Antropologia e a Sociologia de forma a avançar o entendimento da dinâmica das redes.

Outros trabalhos disponíveis são Wright e McAuley (2012) que revisam a pesquisa australiana sobre franquias. Por fim, Chabowski et al. (2011) revisam a literatura subjacente e verificam grande influência da pesquisa em varejo sobre sistemas de franquia. 
Por fim, o Quadro 2 relaciona a pesquisa empírica quantitativa publicada nos últimos 15 anos, levantada para o presente estudo. Apesar de não ser exaustiva, esta relação contém aqueles trabalhos mais diretamente relacionados ao fenômeno aqui estudado. 
Quadro 2 - Síntese da Literatura usada no Referencial Teórico

\begin{tabular}{|c|c|c|c|}
\hline Autor(es) & Tema do Artigo & Teoria(s) Aplicada(s) & Principais Conclusões do Artigo \\
\hline Bradach (1997) & $\begin{array}{l}\text { Utilização do mix contratual } \\
\text { para equilibrar uniformidade e } \\
\text { grau de adaptação a múltiplos } \\
\text { mercados }\end{array}$ & Teoria Institucional & $\begin{array}{l}\text { Existem complementaridades entre lojas próprias e } \\
\text { franqueadas que auxiliam as redes a desenvolver estratégias } \\
\text { voltadas a mercados locais sem com isso descaracterizar atributos } \\
\text { do produto e a identidade de sua marca. }\end{array}$ \\
\hline Wimer e Garen (1997) & $\begin{array}{l}\text { Efeitos da especificidade de } \\
\text { ativos sobre taxas de franquia }\end{array}$ & $\begin{array}{l}\text { Economia dos Custos } \\
\text { de Transação }\end{array}$ & $\begin{array}{l}\text { - Aumentos no produto marginal (insumo) do franqueador elevam } \\
\text { a taxa de royalties. } \\
\text { - Maiores níveis de especificidade de ativos adquiridos por } \\
\text { franqueados aumentam as rendas totais da relação. Por outro } \\
\text { lado, aumentam também as barreiras de saída do franqueado, de } \\
\text { forma que o franqueador eleva os royalties praticados. }\end{array}$ \\
\hline Sen (1998) & Crescimento de redes & $\begin{array}{l}\text { Teoria dos Recursos } \\
\text { Escassos }\end{array}$ & $\begin{array}{l}\text { - A adoção de franquias alivia restrições de capital e de } \\
\text { capacidade gerencial das firmas, potencializando o crescimento. }\end{array}$ \\
\hline Brickley (1999) & $\begin{array}{l}\text { Provisões contratuais e risco } \\
\text { de externalidade }\end{array}$ & Teoria da Agência & $\begin{array}{l}\text { - Contratos mais completos (com mais provisões) são prováveis } \\
\text { quando os atributos do formato de negócios da rede são mais } \\
\text { suscetíveis a problemas de externalidade. }\end{array}$ \\
\hline Combs e Ketchen (1999) & Decisão de franquear & $\begin{array}{l}\text { Teoria da Agência e } \\
\text { Teoria dos Recursos } \\
\text { Escassos }\end{array}$ & $\begin{array}{l}\text { - Quanto menos familiar ao franqueador o mercado (no exterior, } \\
\text { por exemplo), maior a propensão à franchising. } \\
\text { - A especificidade de ativos favorece a adoção de franquias } \\
\text { porque age o incentivo de agentes contratados. Porém, se o ativo } \\
\text { específico diz respeito ao conhecimento acumulado pela rede, a } \\
\text { tendência é a de usar menos franquias. } \\
\text { - Maiores níveis de escassez de recursos (capital e outros) } \\
\text { elevação a propensão à franchising. }\end{array}$ \\
\hline
\end{tabular}




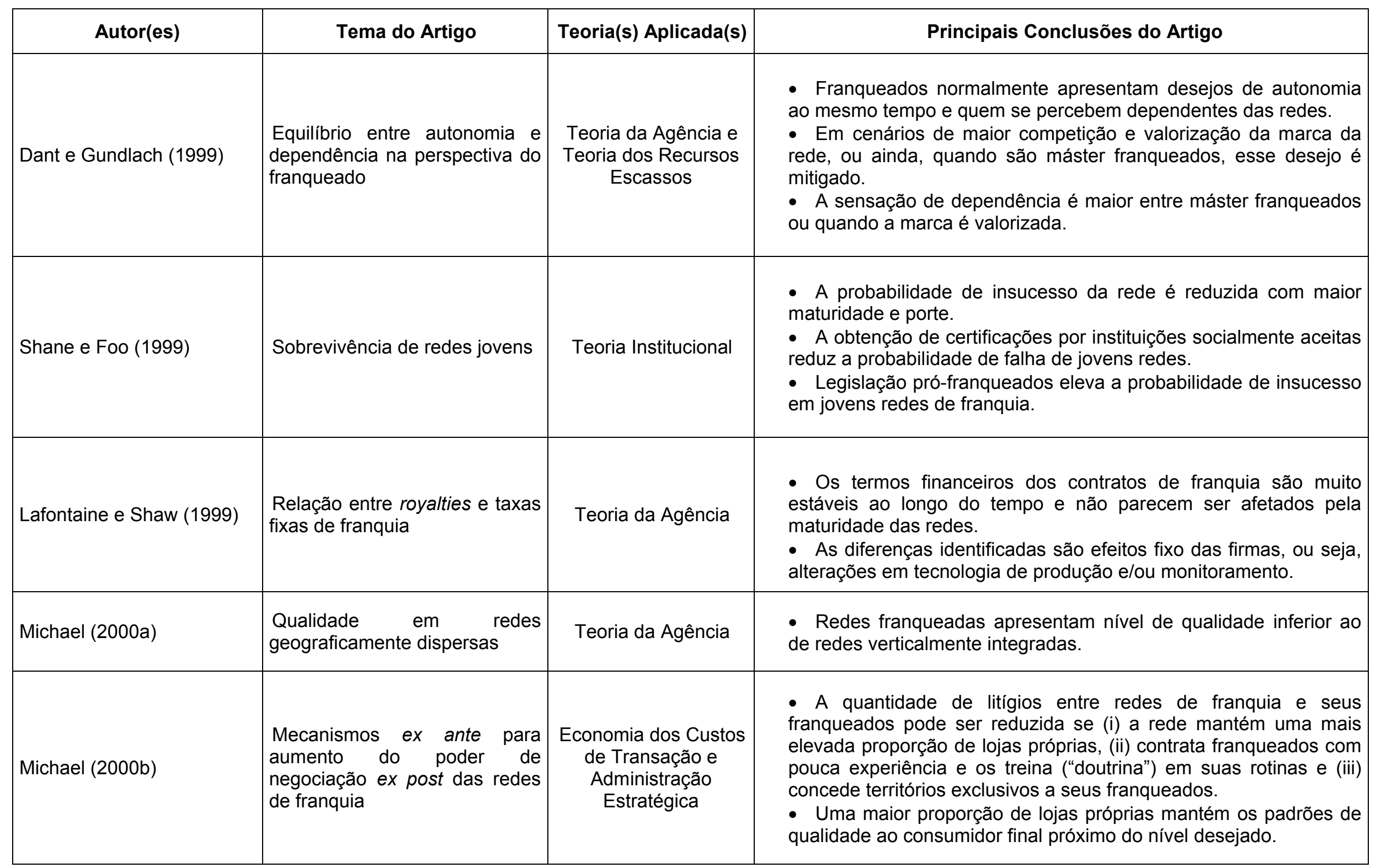




\begin{tabular}{|c|c|c|c|}
\hline Autor(es) & Tema do Artigo & Teoria(s) Aplicada(s) & Principais Conclusões do Artigo \\
\hline Price (2000) & $\begin{array}{llr}\text { Disclosure } & \text { ex ante gerando } \\
\text { maiores } & \text { exigências r do } \\
\text { franqueado } & & \end{array}$ & Teoria da Informação & $\begin{array}{l}\text { - Quanto mais informação divulgada pelo franqueador nos } \\
\text { circulares de oferta de franquia (UFOC), maiores será os royalties } \\
\text { cobrados e o risco de investimento assumido pelo franqueado. }\end{array}$ \\
\hline $\begin{array}{l}\text { Arruñada, Garicano } \\
\text { e Vasquez (2001) }\end{array}$ & $\begin{array}{l}\text { Alocação ex ante de direitos de } \\
\text { decisão em contratos de } \\
\text { franquia }\end{array}$ & $\begin{array}{l}\text { Contratos } \\
\text { Incompletos }\end{array}$ & $\begin{array}{l}\text { - A presença conjunta de maior reputação do franqueador e risco } \\
\text { moral do franqueado explicam contratos que reduzem a } \\
\text { discricionariedade do franqueado. } \\
\text { - Uma maior reputação da montadora e de seus produtos está } \\
\text { associada a um maior número de mecanismos de monitoramento e } \\
\text { contractual self enforcement (desconto em preços e terminação). }\end{array}$ \\
\hline Azoulay e Shane (2001) & $\begin{array}{l}\text { Insucesso em redes de } \\
\text { franquia }\end{array}$ & $\begin{array}{l}\text { Economia dos Custos } \\
\text { de Transação }\end{array}$ & $\begin{array}{l}\text { - A concessão de territórios exclusivos está relacionada a uma } \\
\text { maior certeza de sobrevivência de jovens redes. } \\
\text { - Um maior nível de conhecimento quanto a práticas de } \\
\text { contratação por parte dos gestores de redes jovens está associado } \\
\text { à concessão de territórios exclusivos a franqueados. }\end{array}$ \\
\hline Kaufmann e Dant (2001) & $\begin{array}{l}\text { Relação entre royalties e taxas } \\
\text { fixas de franquia }\end{array}$ & Teoria da Agência & $\begin{array}{l}\text { - Ambas as taxas variam no mesmo sentido quando se controla } \\
\text { para vendas por unidade. }\end{array}$ \\
\hline Frazer (2001) & $\begin{array}{l}\text { Insucesso de unidades } \\
\text { franqueadas }\end{array}$ & Ciclo de Vida & $\begin{array}{l}\text { - Redes maduras e de maior porte apresentam maior } \\
\text { probabilidade de terem problemas de relacionamento com } \\
\text { franqueados, capazes de resultar no fechamento de unidades. }\end{array}$ \\
\hline
\end{tabular}




\begin{tabular}{|c|c|c|c|}
\hline Autor(es) & Tema do Artigo & Teoria(s) Aplicada(s) & Principais Conclusões do Artigo \\
\hline Michael (2001) & 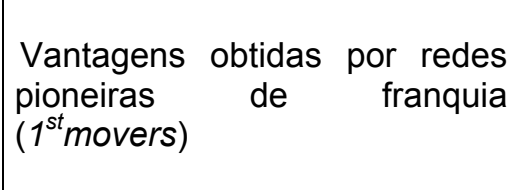 & $\begin{array}{l}\text { Teoria dos Recursos } \\
\text { Escassos }\end{array}$ & $\begin{array}{l}\text { - Redes pioneiras conseguiram estabelecer unidades em uma } \\
\text { maior proporção de localidades em relação aos concorrentes. } \\
\text { - Com isso, alcançaram maior market share e maior lucratividade } \\
\text { em suas operações. }\end{array}$ \\
\hline $\begin{array}{l}\text { Sorenson e Sørensen } \\
\text { (2001) }\end{array}$ & $\begin{array}{l}\text { Relação entre mix contratual } \\
\text { afetando o balanceamento } \\
\text { entre padronização de redes e } \\
\text { adaptação local }\end{array}$ & $\begin{array}{l}\text { Aprendizado } \\
\text { Organizacional }\end{array}$ & $\begin{array}{l}\text { - Gerentes empregados de lojas próprias aprimoram rotinas já } \\
\text { existentes. } \\
\text { - Franqueados, buscam inovar desenvolvendo novas rotinas de } \\
\text { forma a aumentar o nível de eficiência (e lucratividades) de sua(s) } \\
\text { loja(s). } \\
\text { - A existência de formas plurais visa equilibrar os benefícios } \\
\text { advindos de ambas as práticas. }\end{array}$ \\
\hline Windsperger (2001) & $\begin{array}{l}\text { Relação entre royalties e taxas } \\
\text { fixas de franquia }\end{array}$ & $\begin{array}{l}\text { Direitos de } \\
\text { Propriedade }\end{array}$ & $\begin{array}{l}\text { - A determinação de ambas as taxas é função da presença e } \\
\text { importância relativa de ativos intangíveis (marca, know-how, etc.). } \\
\text { - Entre franqueado e franqueador, quem detiver os ativos } \\
\text { intangíveis que mais contribuem para o aumento do resíduo total } \\
\text { será mais beneficiado pela disposição das taxas. } \\
\text { - As taxas tendem a variar na mesma direção. }\end{array}$ \\
\hline Roh (2002) & Mix contratual & Multiteórico & $\begin{array}{l}\text { - A proporção franqueada tende a ser menor em redes } \\
\text { caracterizadas por lojas de grande porte. } \\
\text { - O crescimento da rede é potencializado por uma maior } \\
\text { proporção de lojas franqueadas. } \\
\text { - Mais lojas franqueadas também elevam o valor de mercado da } \\
\text { rede ao mesmo tempo em que reduzem seu risco percebido. }\end{array}$ \\
\hline
\end{tabular}




\begin{tabular}{|c|c|c|c|}
\hline Autor(es) & Tema do Artigo & Teoria(s) Aplicada(s) & Principais Conclusões do Artigo \\
\hline Brickley (2002) & $\begin{array}{l}\text { Relação entre royalties e taxas } \\
\text { fixas de franquia sob influência } \\
\text { da legislação de franquia em } \\
\text { estados dos EUA. }\end{array}$ & $\begin{array}{l}\text { Teoria da Agência e } \\
\text { Direitos de } \\
\text { Propriedade }\end{array}$ & $\begin{array}{l}\text { - O equilibrio entre taxas fixas e variáveis é orientado pelo risco } \\
\text { moral bilateral. } \\
\text { - Leis que protegem excessivamente franqueados aumentam a } \\
\text { propensão ao oportunismo, levando franqueadores a } \\
\text { reestruturarem suas taxas. } \\
\text { - Nestes casos, as taxas de royalties são elevadas de forma que } \\
\text { a rede consegue compensar perdas em litígios. } \\
\text { - Para manter a atratividade do sistema, as taxas fixas são } \\
\text { reduzidas. } \\
\text { - As taxas variam conforme o grau de importância da } \\
\text { contribuição de cada parte para o sucesso da operação. }\end{array}$ \\
\hline $\begin{array}{l}\text { Castrogiovanni e } \\
\text { Justis (2002) }\end{array}$ & $\begin{array}{l}\text { Crescimento de redes de } \\
\text { franquia }\end{array}$ & $\begin{array}{c}\text { Teoria da Agência e } \\
\text { Teoria dos Recursos } \\
\text { Escassos }\end{array}$ & $\begin{array}{l}\text { - Constata-se certa inércia sobre o crescimento das redes. } \\
\text { Redes com tendência de crescimento no período anterior à análise } \\
\text { mantém o crescimento e vice-versa. } \\
\text { - Redes mais maduras apresentam menos crescimento em } \\
\text { função da saturação de mercados possíveis. }\end{array}$ \\
\hline $\begin{array}{l}\text { Penard, Raynaud } \\
\text { e Saussier (2003) }\end{array}$ & $\begin{array}{l}\text { Relação entre royalties de mix } \\
\text { contratual }\end{array}$ & Teoria da Agência & $\begin{array}{l}\text { - O mix contratual é estável a partir de determinada fase do ciclo } \\
\text { de vida e é usado pela rede como mecanismos de monitoramento. } \\
\text { - Com base na informação gerada pelas lojas próprias, as taxas } \\
\text { de royalties são estabelecidas, havendo assim uma relação } \\
\text { positiva entre royalties e proporção de lojas próprias. }\end{array}$ \\
\hline
\end{tabular}




\begin{tabular}{|c|c|c|c|}
\hline Autor(es) & Tema do Artigo & Teoria(s) Aplicada(s) & Principais Conclusões do Artigo \\
\hline $\begin{array}{l}\text { Arruñada, Garicano } \\
\text { e Vasquez (2005) }\end{array}$ & $\begin{array}{l}\text { Compleição ex post de } \\
\text { contratos de franquia }\end{array}$ & $\begin{array}{l}\text { Contratos } \\
\text { Incompletos }\end{array}$ & $\begin{array}{l}\text { - Incerteza do ambiente e risco moral do franqueador não são } \\
\text { suficientes para impedir a formação de contratos se o franqueador } \\
\text { possui capital reputacional acumulado. }\end{array}$ \\
\hline Lafontaine e Shaw (2005) & Variação do mix contratual & Teoria da Agência & $\begin{array}{l}\text { - Redes maduras mantém constante o mix contratual ao longo do } \\
\text { tempo. } \\
\text { - O principal determinante do mix contratual é o valor da marca, } \\
\text { uma vez que, quanto mais valiosa, maior o incentivo ao free-riding } \\
\text { de franqueados. } \\
\text { - Assim, ao possuir e operar lojas próprias, as redes as usam } \\
\text { como mecanismos de monitoramento e coleta de informação. }\end{array}$ \\
\hline $\begin{array}{l}\text { Brickley, Misra e Van Horn } \\
\text { (2006) }\end{array}$ & $\begin{array}{l}\text { Extensão dos prazos de } \\
\text { contratos de franquia }\end{array}$ & $\begin{array}{l}\text { Economia dos Custos } \\
\text { de Transação e Teoria } \\
\quad \text { da Agência }\end{array}$ & $\begin{array}{l}\text { - A extensão do prazo de contrato varia de acordo com os } \\
\text { investimentos demandados do franqueado em ativos físicos e } \\
\text { humanos. } \\
\text { - Estes prazos também variam com a maturidade da rede. } \\
\text { - Redes mais jovens operando em setores mais maduros, com } \\
\text { práticas já estabelecidas, também oferecem prazos maiores. }\end{array}$ \\
\hline $\begin{array}{l}\text { Castrogiovanni, Combs e } \\
\text { Justis (2006) }\end{array}$ & $\begin{array}{l}\text { Decisão de franquear em } \\
\text { cenários internacionais }\end{array}$ & $\begin{array}{l}\text { Teoria da Agência e } \\
\text { Teoria dos Recursos } \\
\quad \text { Escassos }\end{array}$ & $\begin{array}{l}\text { - A crescente elevação de custos de monitoramento decorrente } \\
\text { da expansão da rede, particularmente em direção a outros países, } \\
\text { eleva a propensão de elevação na proporção de lojas } \\
\text { franqueadas. } \\
\text { - O oposto ocorre em redes que, ao invés de se expandir } \\
\text { geograficamente, optam por aumentar o tamanho das lojas. } \\
\text { - Redes de grande porte, com capacidade para desenvolver } \\
\text { rotinas e tecnologia de monitoramento, conseguem manter a } \\
\text { propriedade de um maior número de lojas. }\end{array}$ \\
\hline
\end{tabular}




\begin{tabular}{|c|c|c|c|}
\hline Autor(es) & Tema do Artigo & Teoria(s) Aplicada(s) & Principais Conclusões do Artigo \\
\hline $\begin{array}{l}\text { Cataluña, Garcia e Castro } \\
\text { (2007) }\end{array}$ & $\begin{array}{l}\text { Identificação de grupos } \\
\text { estratégicos }\end{array}$ & $\begin{array}{l}\text { Teoria da Agência e } \\
\text { Teoria dos Recursos } \\
\text { Escassos }\end{array}$ & $\begin{array}{l}\text { Os grupos identificados são: redes estáveis de alto } \\
\text { investimento, redes maduras, redes de rápido crescimento e redes } \\
\text { convertidas. }\end{array}$ \\
\hline Cox e Mason (2007) & $\begin{array}{l}\text { A influência da dicotomia entre } \\
\text { padronização e adaptação em } \\
\text { unidades de franquia }\end{array}$ & Teoria da Agência & $\begin{array}{l}\text { - As redes exigem cumprimento das especificações para } \\
\text { atributos chave do formato de negócio (produto, identidade visual, } \\
\text { layout da loja, etc.), mas flexibilizam atributos periféricos atrás da } \\
\text { linha de visibilidade nas unidades. }\end{array}$ \\
\hline Barthélemy (2008) & $\begin{array}{l}\text { Efeitos do } \quad \text { risco de } \\
\text { comportamento } \quad \text { inadequado } \\
\text { sobre o desempenho geral da } \\
\text { rede }\end{array}$ & $\begin{array}{l}\text { Visão Baseadas em } \\
\text { Recursos }\end{array}$ & $\begin{array}{l}\text { - Redes com marcas valiosas são mais suscetíveis aos } \\
\text { problemas de free-riding, de forma que nestes casos, uma maior } \\
\text { proporção de lojas próprias é associada a um melhor desempenho. } \\
\text { - O problema de free-riding é agravado pela presença de } \\
\text { processos com maior nível de serviço e mais dificuldade de } \\
\text { mensuração e monitoramento. } \\
\text { - Redes com maior proporção franqueada se resguardam de } \\
\text { transmitir conhecimento tácito, o que inibe o desempenho global. }\end{array}$ \\
\hline
\end{tabular}




\begin{tabular}{|c|c|c|c|}
\hline Autor(es) & Tema do Artigo & Teoria(s) Aplicada(s) & Principais Conclusões do Artigo \\
\hline Barthélemy (2008) & $\begin{array}{l}\text { Efeitos do risco de } \\
\text { comportamento } \\
\text { sobre o desempenho geral da } \\
\text { rede }\end{array}$ & $\begin{array}{l}\text { Visão Baseadas em } \\
\text { Recursos }\end{array}$ & $\begin{array}{l}\text { - Redes com marcas valiosas são mais suscetíveis aos } \\
\text { problemas de free-riding, de forma que nestes casos, uma maior } \\
\text { proporção de lojas próprias é associada a um melhor desempenho. } \\
\text { - O problema de free-riding é agravado pela presença de } \\
\text { processos com maior nível de serviço e mais dificuldade de } \\
\text { mensuração e monitoramento. } \\
\text { - Redes com maior proporção franqueada se resguardam de } \\
\text { transmitir conhecimento tácito, o que inibe o desempenho global. }\end{array}$ \\
\hline Chaudey e Fadairo (2008) & $\begin{array}{l}\text { Provisões contratuais e risco } \\
\text { de externalidade }\end{array}$ & Teoria da Agência & $\begin{array}{l}\text { - Contratos mais completos (com mais provisões) são prováveis } \\
\text { quando os atributos do formato de negócios da rede são mais } \\
\text { suscetíveis a problemas de externalidade. }\end{array}$ \\
\hline $\begin{array}{l}\text { Maruyama e Yamashita } \\
\text { (2008) }\end{array}$ & $\begin{array}{l}\text { Relação entre royalties e taxas } \\
\text { fixas de franquia }\end{array}$ & Teoria da Agência & $\begin{array}{l}\text { - No contexto do risco moral bilateral, as taxas fixas e variáveis } \\
\text { se ajustam para remunerar a parte mais importante na relação (no } \\
\text { caso, o franqueador). }\end{array}$ \\
\hline $\begin{array}{l}\text { Arruñada, Vasquez e } \\
\text { Zanarone (2009) }\end{array}$ & $\begin{array}{l}\text { Efeitos do ambiente } \\
\text { institucional sobre a escolha da } \\
\text { do arranjo de governança }\end{array}$ & $\begin{array}{l}\text { Teoria da Agência e } \\
\text { Institucional }\end{array}$ & $\begin{array}{l}\text { - No mercado de concessionárias de veículos na Espanha, lojas } \\
\text { de propriedade das montadoras apresentam produtividade e } \\
\text { lucratividade menores e custos trabalhistas maiores. } \\
\text { - Estas lojas não são convertidas à franquias em função dos } \\
\text { custos trabalhistas e do poder de barganha dos sindicatos dos } \\
\text { funcionários da indústria automobilística. }\end{array}$ \\
\hline
\end{tabular}




\begin{tabular}{|c|c|c|c|}
\hline Autor(es) & Tema do Artigo & Teoria(s) Aplicada(s) & Principais Conclusões do Artigo \\
\hline $\begin{array}{l}\text { Campbell, Datar e Sandino } \\
\text { (2009) }\end{array}$ & $\begin{array}{l}\text { A influência da operação em } \\
\text { múltiplos tipos de mercados } \\
\text { sobre a decisão de franquear }\end{array}$ & Teoria da Agência & $\begin{array}{l}\text { - A decisão de franquear algumas ou todas as unidades de uma } \\
\text { rede é associada à diversidade entre os mercados ocupados. } \\
\text { - Simultaneamente, a opção pelo arranjo de franquias } \\
\text { inexoravelmente leva a rede a participar de mercados dispares. } \\
\text { - A decisão de franquear uma loja específica é influenciada pelo } \\
\text { grau de disparidade entre o mercado desta loja e o mercado típico } \\
\text { do restante da rede. }\end{array}$ \\
\hline $\begin{array}{l}\text { Combs, Michael e } \\
\text { Castrogiovanni (2009) }\end{array}$ & $\begin{array}{l}\text { Influências institucionais sobre } \\
\text { a escolha do arranjo } \\
\text { organizacional }\end{array}$ & Institucional & $\begin{array}{l}\text { - Existe certo mimetismo no setor de franquias, com firmas sendo } \\
\text { influenciadas pela concorrência direta a optar pelo arranjo de } \\
\text { franquias. } \\
\text { - O mix contratual das redes é inercial, existindo um efeito de } \\
\text { path dependence na determinação do mesmo. } \\
\text { - O efeito path dependence sobre o mix contratual é atenuado } \\
\text { pela dispersão geográfica, uma vez que as redes optam por usar } \\
\text { franquias em localidades mais distantes. }\end{array}$ \\
\hline Michael (2009) & Atração de franqueados & Teoria da Sinalização & $\begin{array}{l}\text { - Redes com muitas unidades próprias divulgam mais dados } \\
\text { sobre desempenho para sinalizar qualidade a franqueados } \\
\text { potenciais. }\end{array}$ \\
\hline $\begin{array}{l}\text { Bordonaba-Juste, Lucia- } \\
\text { Palacios e Polo-Redondo } \\
\text { (2010) }\end{array}$ & Crescimento de redes & $\begin{array}{l}\text { Teoria da Agência e } \\
\text { Ciclo de Vida }\end{array}$ & $\begin{array}{l}\text { - Uma maior proporção de lojas próprias inibe o crescimento. } \\
\text { Essa tendência é agravada na medida em que a rede envelhece. } \\
\text { - O momento vivido pela rede em relação a seu ciclo de vida no } \\
\text { momento em que adota o arranjo de franquias influencia a } \\
\text { adequação de estratégias específicas quanto a incentivos e mix } \\
\text { contratual. }\end{array}$ \\
\hline
\end{tabular}




\begin{tabular}{|c|c|c|c|}
\hline Autor(es) & Tema do Artigo & Teoria(s) Aplicada(s) & Principais Conclusões do Artigo \\
\hline $\begin{array}{l}\text { Martinez-Torres e } \\
\text { Toral-Marin (2010) }\end{array}$ & $\begin{array}{l}\text { Identificação de grupos } \\
\text { estratégicos }\end{array}$ & $\begin{array}{l}\text { Teoria da Agência e } \\
\text { Teoria dos Recursos } \\
\text { Escassos }\end{array}$ & $\begin{array}{l}\text { Os grupos identificados são: redes de alto investimento, redes } \\
\text { internacionais, redes de grande crescimento, redes de baixo } \\
\text { crescimento e redes convertidas. }\end{array}$ \\
\hline $\begin{array}{l}\text { Garcia-Herrera e } \\
\text { Llorca-Vivero (2010) }\end{array}$ & $\begin{array}{l}\text { Extensão dos prazos de } \\
\text { contratos de franquia }\end{array}$ & $\begin{array}{l}\text { Economia dos Custos } \\
\text { de Transação e Teoria } \\
\quad \text { da Agência }\end{array}$ & $\begin{array}{l}\text { - Maiores prazos dos contratos de franquia estão relacionados } \\
\text { entre o investimento fixo de franqueados. No entanto, esta relação } \\
\text { é moderada pela margem de lucro da unidade e pelo valor da } \\
\text { marca da rede. } \\
\text { - Os prazos poderiam divergir mais entre as redes, no entanto, } \\
\text { aspectos de padronização entre redes (por mimetismo ou } \\
\text { institucionalização) impede esta variação. }\end{array}$ \\
\hline $\begin{array}{l}\text { Blut, Backhaus, Heussler, } \\
\text { Woisetschlager, } \\
\text { Evanschitzky e Ahlert } \\
\text { (2011) }\end{array}$ & $\begin{array}{l}\text { Ciclo de vida em redes de } \\
\text { franquia }\end{array}$ & Ciclo de Vida & $\begin{array}{l}\text { - A intensidade de mecanismos de coordenação entre a rede e } \\
\text { seus franqueados é maior nos primeiro meses de relacionamento } \\
\text { em função da inexperiência do franqueado. } \\
\text { - Com a maturidade da relação, o número de conflitos diminui, } \\
\text { mas volta a crescer em função de problemas de distribuição } \\
\text { (partilha de resíduo, saturação de mercados com novas unidades, } \\
\text { etc.) } \\
\text { - Uma forma de reduzir o montante de problemas na fase } \\
\text { madura da relação é conceder novas franquias ao franqueado } \\
\text { (única forma de aumentar a renda de lojas que alcançaram o } \\
\text { máximo da capacidade de mercado). }\end{array}$ \\
\hline
\end{tabular}




\begin{tabular}{|c|c|c|c|}
\hline Autor(es) & Tema do Artigo & Teoria(s) Aplicada(s) & Principais Conclusões do Artigo \\
\hline Vásquez (2010) & $\begin{array}{l}\text { Relação entre royalties e taxas } \\
\text { fixas de franquia }\end{array}$ & Teoria da Agência & $\begin{array}{l}\text { - Os royalties praticados são compostos também pelo lucro } \\
\text { obtido pelo franqueador nos insumos fornecidos a franqueados. } \\
\text { - As taxas (fixa e variável) variam em consonância com a } \\
\text { importância do produto marginal entre as partes. Quanto mais } \\
\text { importante o esforço do franqueado e a dificuldade de mensura-lo, } \\
\text { maiores as taxas fixas e menores os royalties (e vice-versa). } \\
\text { - Em operações com maior risco (por exemplo, variabilidade de } \\
\text { demanda), as taxas fixas decrescem em proporção ao aumento } \\
\text { em royalties. } \\
\text { - Franqueadores recuperam o investimento feito em suportar } \\
\text { franqueados através de royalties. Similarmente, quando dispêndios } \\
\text { com locação, seleção e treinamento de novos franqueados são } \\
\text { altos, este investimento é recuperado com taxas fixas iniciais mais } \\
\text { altas. }\end{array}$ \\
\hline $\begin{array}{l}\text { Polo-Redondo, Bordonaba- } \\
\text { Juste e Lucia-Palacios } \\
\text { (2011) }\end{array}$ & $\begin{array}{l}\text { Determinantes do porte de } \\
\text { redes de franquia }\end{array}$ & $\begin{array}{c}\text { Teoria da Sinalização, } \\
\text { Visão Baseada em } \\
\text { Recursos e Ciclo de } \\
\text { Vida }\end{array}$ & $\begin{array}{l}\text { - Em função das dificuldades enfrentadas por redes pioneiras em } \\
\text { relação a redes seguidoras }\left(2^{\text {nd }} \text {-movers), porte e ciclo de vida }\right. \\
\text { apresentam uma relação curvilinear na forma de "U" invertido. } \\
\text { - Uma maior proporção de lojas próprias limita o crescimento da } \\
\text { rede. } \\
\text { - Em redes mais maduras existe uma relação negativa entre o } \\
\text { porte e a proporção de lojas próprias. } \\
\text { - Na medida em que amadurecem, as redes conseguem } \\
\text { converter a experiência e reputação acumuladas em maiores taxas } \\
\text { fixas e royalties. }\end{array}$ \\
\hline
\end{tabular}




\section{ABORDAGEM METODOLÓGICA}

Esta seção envolve alguns aspectos epistemológicos do presente estudo, o qual é voltado para entender aspectos determinantes do crescimento de redes de franquia no Brasil.

A metodologia de análise empregada no estudo consiste de uma combinação de métodos estatísticos multivariados e análises econométricas aplicados sobre dados secundários de 376 redes de franquia brasileiras. O detalhamento dos procedimentos aplicados na análise está disponível nos Capítulos 6 e 7.

A metodologia empregada é ainda orientada pelo paradigma empírico positivista. Ou seja, busca-se a explicação do fenômeno a partir da identificação de suas relações, privilegiando a abordagem estatística para decodificação dessas relações e tendo teorias como lógica norteadora (MARTINS; THEÓPHILO, 2009).

\subsection{Problema de Pesquisa}

A literatura indica uma lacuna no entendimento do arranjo de franquias no Brasil. Mesmo no cenário internacional são poucos os estudos empíricos orientados por teoria a abordar a questão.

Apesar de algumas exceções (SEN, 1998; CASTROGIOVANNI; JUSTIS, 2002; SHANE et al., 2006), a maioria dos estudos empíricos relacionando o arranjo de franquia a desempenho o fazem pela perspectiva da performance financeira (COMBS et al., 2004). Outros analisam o porte da rede em termos do número de unidades de forma estática (POLO-REDONDO et al., 2011). Outros ainda analisam o crescimento como variável explicativa para o mix contratual $(\mathrm{ROH}, 2002)$. No entanto, trabalhos relacionados ao crescimento de redes de franquia não são comuns. Contribuir para o aumento do conhecimento neste setor é uma das motivações deste estudo.

Diferenças idiossincráticas entre setores e entre firmas são esperadas, de forma que os efeitos dos fatores determinantes tendem a não ser homogêneos. Assim, modelos customizados para diferentes grupos de redes são necessários. Ao 
invés de seguir uma taxonomia pré-concebida, procura-se inicialmente identificar grupos de redes de franquia com atributos similares.

Para tanto, busca-se na literatura de ciclo de vida e grupos estratégicos referências para efetuar o agrupamento necessário. A identificação de atributos comuns entre as redes permitiria interpretar aspectos do comportamento estratégico destas firmas. Propõe-se que tal comportamento é resultante de um processo histórico de interação entre as redes e forças de mercado (path dependence).

A interpretação destes atributos (com base nas teorias subjacentes) torna possível identificar também grupos estratégicos. Como mencionado anteriormente, o conceito de estratégia aqui adotado refere-se ao conjunto de escolhas feitas pela firma ao longo de sua trajetória (ex post). A estratégia das redes de cada grupo é assim o resultado do caminho percorrido pelas redes do grupo ao longo do ciclo de vida.

Considerando que o comportamento estratégico reflete as experiências vividas e acumuladas ao longo do ciclo de vida, infere-se a existência de elevados custos de mudança. Ou seja, existiria pouca mobilidade entre os grupos de forma que os grupos são relativamente estáveis ${ }^{17}$. Assim, uma taxonomia é possível. Uma vez conhecidos e analisados os grupos, parte-se então para identificar os determinantes do crescimento e seus efeitos entre os grupos.

Com base na teoria da agência, economia dos custos de transação e teoria dos recursos escassos, dois construtos teóricos são confrontados ao crescimento das redes: o risco na operação decorrente do risco de comportamento oportunista de franqueados e os mecanismos de incentivos empregados pelo franqueador visando potencializar esforço pelo operador local.

Assim, modelos analíticos customizados para os grupos estratégicos são testados de forma a verificar como se ocorre o crescimento das redes de franquia no Brasil. Em suma, o presente estudo tem como motivação responder ao seguinte problema de pesquisa:

17 Como será discutido adiante, algumas redes estão posicionadas "na margem" de seus grupos, de forma que seu perfil estratégico ainda é difuso. Embora não seja um objeto de investigação deste estudo, espera-se que estas redes apresentem desempenho pior em relação àquelas que efetivamente apresentam o perfil apontado nos grupos. 
O que explica o crescimento do número de lojas em redes de franquia no Brasil?

Algumas questões de pesquisa podem ser derivadas:

- Quais são os grupos estratégicos identificáveis entre as redes de franquia no Brasil?

- Quais são e como influenciam os determinantes do crescimento?

- Existem efeitos antagônicos entre grupos de redes com comportamento estratégico similar?

- Existe algum efeito de path dependence influenciando crescimento?

\subsection{Objetivos}

Do ponto de vista científico, intenciona-se avançar o entendimento da evolução de arranjos de governança alternativos à integração vertical, nos quais se encaixa o modelo de franquias. Para tanto, utiliza-se o setor de franquias no Brasil como laboratório e o crescimento das redes como fenômeno de estudo.

Adicionalmente, objetivou-se a geração de análises com potencial para orientar administradores de redes de franquia, bem como demais profissionais relacionados, no sentido de aumentar a eficiência do setor e a geração de riquezas para o país.

Além disso, alguns objetivos secundários foram alcançados. Primeiramente, foi possível trazer para o contexto brasileiro a discussão em torno de grupos estratégicos entre as redes de franquia. Apesar de alguns exemplos na literatura internacional (ver Seção 4.6), não existe pesquisa similar envolvendo o setor de franquias do Brasil.

Em segundo lugar, foi possível avançar a discussão dos grupos estratégicos. A maioria das pesquisas consultadas se limita a discutir o perfil dos grupos, sem buscar verificar possíveis diferenças em desempenho.

Por fim, foi possível captar aspectos da interação do setor de franquias com o setor de shopping centers, além da crescente presença de redes de franquia em mercados emergentes no cenário brasileiro. Este tema se mostra carente de 
avanços mesmo na literatura internacional, pelo menos nos periódicos indexados consultado para esta pesquisa.

\subsection{Hipótese Central}

Redes de franquia praticam um jogo de ocupação de espaços geográficos dotados de mercados com potencial de consumo para seus produtos e serviços (proposta de valor do produto). Ou seja, um jogo que consiste em seleção e ocupação de nichos de mercado alvo.

A rede ocupará estes espaços buscando maximizar seu valor, incluindo a minimização dos custos de coordenação. Tais custos podem ser mitigados verticalmente, através da opção pelo arranjo de franquia; e horizontalmente, equilibrando mecanismos de incentivo e monitoramento.

Franqueados potenciais são atraídos através da oferta de um fluxo de caixa atrativo a operadores locais, equilibrando as taxas praticadas (fixas e variáveis) com o potencial de mercado das lojas e aspectos de reputação da marca. Além disso, mecanismos de monitoramento e controle são empregados para mitigar riscos de externalidades negativas como o free-riding.

As escolhas não são totalmente deliberadas ex ante, existindo um efeito path dependence que condiciona a forma como o jogo de expansão é praticado. Tal comportamento estratégico no Brasil dá forma a grupos de redes com comportamento similar, os quais denominados de grupos estratégicos. Tais grupos são caracterizados principalmente pelo estágio do ciclo de vida das redes que deles.

Redes jovens se beneficiam das experiências realizadas em tecnologia do setor. Elas não precisam incorrer em custos de mudança similares àqueles que afetam redes mais quando da necessidade de corrigir sua obsolescência tecnológica. O impacto da automação no desempenho destas redes é acompanhado de um menor custo de mudança. Não afetando a atratividade da proposta de valor dado que não precisariam acomodar tais custos de mudança tecnológica nem na lucratividade geral da rede, nem repassando aos franqueados através de taxas de franquia. 
Assim, a hipótese central do estudo é a de que o crescimento das redes é função de dois fatores: risco na operação e da atratividade da proposta de valor da rede a seus operadores locais. Enquanto o risco na operação representa potenciais perdas decorrentes de problemas de coordenação e controle ineficientes, a atratividade decorre dos mecanismos de incentivos empregados pelo franqueador. Ambos os fatores são moderados pelo estágio do ciclo de vida em que as redes se encontram e, consequentemente, do comportamento estratégico decorrente e característico deste estágio.

\subsection{Desenvolvimento das Hipóteses}

Dois construtos são operacionalizados para dar forma ao modelo de análise: risco na operação e dinâmica de incentivos.

\subsubsection{Risco na Operação}

O fato de lidar com incentivos mais poderosos não elimina totalmente o risco de comportamento inadequado do franqueado (BROWN, 1998). Agentes operando em redes com capital reputacional acumulado podem ter incentivos para expropriar renda das redes. Ou seja, ao economizar esforço e insumos e entregar produtos abaixo da qualidade esperada pelo cliente da marca, o agente pode se beneficiar sozinho com essa economia enquanto partilha com o restante da rede a perda de reputação (KLEIN, 1985). Este é um quadro de potencial geração de externalidades negativas para toda a rede, uma vez que o desempenho das demais unidades pode ser afetado.

A manutenção da padronização no produto transacionado em cada unidade sustenta o racional de franquias. Este conceito se justifica de duas formas. Primeiramente, maiores níveis de padronização propiciam às redes franqueadas a estabelecer sua proposta de valor ao cliente final de maneira uniforme entre as diversas unidades, fortalecendo a identidade da marca. Em segundo lugar, a padronização permite o estabelecimento de referências para mensurar o desempenho das diversas unidades, potencializando o monitoramento de toda a rede. Em suma, normalização e uniformidade são pilares do conceito franquias. 
Este raciocínio se aproxima do próprio conceito de franchising enquanto formato de negócios, o qual apresenta entre suas características mais notáveis o desenvolvimento de um modelo diferenciado de prestação de serviço que ocorre muito próximo ao consumidor final. Redes com maior êxito conseguem replicar tal serviço em um grande número de unidades geograficamente dispersas (COMBS et al., 2004a).

Mesmo em redes com alto grau de processamento de produtos ocorrendo no interior das unidades, a questão da padronização é alavancada por maiores níveis de automação. Com a ação humana sendo substituída por equipamentos e sistemas computadorizados o produto tende a ser gerado de forma mais uniforme e parametrizada, ou seja, com maior grau de padronização (BROWNELL; MERCHANT, 1990).

No nível de loja, a própria presença de processos mais automatizados e/ou sistematizados potencialmente eleva a capacidade de monitorar a distância. Como colocado por Norton (1988), máquinas não tentam 'fugir' do trabalho. No entanto, pessoas podem ser tentadas a ludibriar, entregando menos esforço do que foi contratado. Para um determinado nível de produção, custos de monitoramento se elevarão com o aumento da intensidade do trabalho.

Sistemas de informação aplicados em processos produtivos permitem controlar o comportamento à distância e com número reduzido de supervisores (BOULAY, 2010). Entende-se que processos produtivos menos dependentes da ação humana podem simultaneamente minimizar a variabilidade do produto e gerar mais informação acerca do desempenho produtivo local. Isso fortalece a coordenação, proporcionando monitoramento mais eficiente e reduzindo o tempo e custos envolvidos na coleta de dados (SIA et al., 2002;. SEWELL; WILKINSON, 1992).

Processos com esta característica teriam efeito disciplinador, uma vez que agentes sob a presunção do monitoramento tendem a agir em conformidade com o que acham ser esperados pelo principal (BOULAY, 2010).

Em suma, processos produtivos baseados em automação e/ou sistematização tendem a reduzir o risco da operação por permitir monitoramento à distância e reduzir a variabilidade do produto. Como consequência, franqueadores 
com este perfil conseguem coordenar melhor suas redes obtendo potencial de crescimento $^{18}$. Formalmente:

\section{H1a. Um maior nível de automação nas lojas eleva a capacidade de monitoramento à distância e reduz o risco potencial nas operações de redes com lojas dispersas, 0 que favorece o crescimento.}

O risco de free-riding é um dos tipos de externalidades de rede previstos pela literatura econômica (KLEIN; SAFT, 1985). O produto oferecido em cada loja transmite ao consumidor o padrão de qualidade característico da marca. Se o consumidor não tem como atestar essa qualidade antes de adquirir o produto, então, o franqueado tem incentivo a economizar esforços e insumos no processo produtivo, afetando os padrões de qualidade da rede.

Ao negligenciar esforços, o franqueado lucra sozinho na economia de seus insumos, enquanto partilha com o restante da rede os custos decorrentes desta ação.

Esse quadro é potencializado se o perfil típico do consumidor da rede é de compras não recorrentes. Ou seja, mesmo sendo fiel à marca, sua experiência de consumo tende a ser realizada em diferentes unidades da rede (BRICKLEY et al, 1991). Assim, se um franqueado economiza esforço e insumos e, por conseguinte, afeta negativamente a qualidade do produto vendido, ele afetará a rede como um todo. Se o consumidor nota a queda da qualidade do produto consumido e cessa ou reduz sua experiência de consumo, toda a rede é penalizada. Neste caso, a reação do consumidor consiste em punir o fraco trabalho de monitoramento do franqueador (KLEIN; SAFT, 1985).

Quanto menor o mercado alcançado por uma determinada loja, maior a probabilidade de compras repetidas por um mesmo cliente naquela loja. Ou seja, se a densidade de lojas em relação a uma determinada população é baixa (menos lojas por habitantes), a probabilidade de compras recorrentes se eleva, de forma que o franqueado arcará com um montante maior da perda de reputação da marca.

\footnotetext{
${ }^{18} \mathrm{Em}$ redes mais antigas e já próximas da estabilização do porte este efeito tende seria mais notado na rentabilidade de cada loja (fluxo de receitas de lojas próprias e de royalties em lojas franqueadas). No entanto, este não é o objeto do presente estudo.
} 
Assim sendo, redes com uma menor densidade de lojas consegue aumentar o alinhamento de incentivos de franqueados, potencializando o desempenho de cada loja. Formalmente:

H1b: Uma menor densidade de lojas em relação à população total alcançada pela rede favorece o crescimento.

Apesar dos dispositivos contratuais e dos aspectos de incentivos que regerem relações de franquia, o monitoramento é essencial para fins de controle e correção de desvios. Neste sentido, a qualidade da informação é sine qua non.

A transmissão de procedimentos e práticas através de treinamento e suportes de ordem operacional molda rotinas da unidade em resposta ao feedback do ambiente e de experiências passadas da rede. De acordo com essa perspectiva, as redes conseguiriam se beneficiar do compartilhamento de rotinas e conhecimentos desenvolvidos ao longo de suas unidades (ARGOTE et al., 1990). Neste sentido, a experiência exerce grande influência em termos de desenvolvimento e capacidade de transmissão de suporte a franqueados (CASTROGIOVANNI et al., 2006).

Assim, em um contexto de controle, franqueadores podem estabelecer diretrizes operacionais, políticas, procedimentos e suporte de marketing. Por sua vez, franqueados devem seguir essas diretrizes e fornecer ao franqueador informações precisas e oportunas sobre vendas e resultados (PASWAN; WITTMANN, 2009). Uma maior formalização do suporte a franqueados propiciaria maior interface da rede com os operadores locais, gerando informação com menos ruído e elevando o nível de coordenação. Assim:

H1c. O aumento no número de suportes oferecidos a
franqueados proporciona maior crescimento,
principalmente em redes mais experientes.

\subsubsection{Dinâmica de Incentivos}

O uso de franchising pode ser considerado uma fonte de vantagem competitiva, pois permite às empresas antecipar bons locais. Quanto maior o número de locais que o franqueador acumula, maior sua cobertura territorial, e mais 
ampla a sua base de clientes. Michael (2003) analisou se há evidências de vantagens do pioneirismo no contexto da franquia. Ele sugeriu que as cadeias de franquias que têm estado no negócio por mais tempo tende a acumular mais locais e, portanto, terá um desempenho melhor.

Shane et al. (2006) elencam razões para que as redes de franquia mantenham elevada a proporção de unidades franqueadas, mesmo após alcançarem porte e maturidade. Primeiramente, de acordo com a teoria de sinalização (signaling theory), redes jovens são instadas a manter algumas lojas próprias, as quais operariam sinalizando ao mercado a qualidade dos atributos que denotam produtos e serviços da rede. Com maiores porte e maturidade, a reputação acumulada torna desnecessário o uso deste estratagema (GALLINI; LUTZ, 1992).

Em segundo lugar, formas organizacionais não hierárquicas como sistemas de franquias tendem a crescer mais rápido do que redes verticalmente integradas (DARR et al., 1995). Isso ocorre pela maior facilidade relativa de redes franqueadas em relação a custo de capital, seleção de funcionários e supervisão gerencial (SHANE, 1996). Portanto, é natural que mesmo redes mais maduras elevem a proporção de lojas franqueadas visando crescimento.

Uma terceira razão para a elevação na proporção franqueada tem a ver com potenciais vantagens sinérgicas do mix contratual (LAFONTAINE; KAUFMANN, 1994). As redes podem limitar seus esforços a administrar lojas próprias em um nível necessário para o controle de qualidade (LAFONTAINE; SHAW, 2005) e focar sua atenção no crescimento através de franquias. Como resultado, a proporção de lojas próprias diminuiria ao longo do tempo.

Por fim, os números recentes da economia brasileira (com crescimento médio do PIB de quase 4\% ao ano entre 2001 e 2011 - fonte: IPEADATA) indicam a ascensão de várias regiões do país, as quais eram antes incipientes e hoje despontam como novos mercados alternativos. É natural que as redes busquem estes mercados. Desde a proposição pioneira de Rubin (1978), TA propõe que a ocupação deste tipo de mercado seja feita através de relações de franquia, com a rede se beneficiando do conhecimento local destes operadores, ao mesmo tempo em que economiza em custos de monitoramento e não incorre em riscos operacionais. Assim, do ponto de vista do crescimento: 
H2a. Uma tendência de elevação na proporção de lojas franqueadas favorece o crescimento da rede.

A proposta clássica de TA para franquia envolve a substituição de monitoramento ineficiente por incentivos (KRUEGER, 1991). Funcionários contratados não lidam com incentivos tão poderosos quanto os de franqueados, o que abre espaço para o baixo nível de esforço do agente [ou shirking, nos termos de Alchian e Demsetz (1972)]. Assim, o montante de royalties gerado a partir de lojas com desempenho potencializado supera o fluxo de receitas de unidas operando com gerentes contratados submetidos a pacotes inferiores de incentivos, o que induz a rede a manter elevada a proporção de lojas franqueadas. Esse é um dos principais argumentos na explicação de franquias da perspectiva da TA.

No entanto, na medida em que adquire maturidade e experiência, a rede consegue lidar melhor como necessidade de coordenação. A própria tecnologia de monitoramento na indústria tende a avançar, possibilitando às redes reequilibrar custos de agência (monitoramento versus incentivos). Isso permitiria ao franqueador reter e/ou converter a propriedade de uma maior proporção de lojas.

Reciprocamente, a visão clássica da TRE indica que, na medida em que a rede adquire experiência e porte, algumas das restrições naturais dos primeiros anos da rede (capital, capacidade gerencial, dentre outras) são mitigadas (OXENFELDT; KELLY, 1969).

Em suma, ambas as vertentes teóricas poderiam esperar uma maior conversão de unidades franqueadas em unidades próprias, na medida em que as redes amadurecem. Assim, principalmente em redes maduras, espera-se verificar um maior número de conversões de lojas franqueadas em lojas próprias acompanhando o crescimento da rede. Por outro lado, em redes jovens, o aumento do mix contratual decorreria de novas lojas franqueadas e não da conversão de lojas próprias. Formalmente:

H2b. Em redes maduras, a conversão de lojas franqueadas em lojas próprias favorece o crescimento.

No setor de franquias, existem dois tipos distintos de consumidores: o cliente final do produto e os potenciais adquirentes do formato de negócios das redes, ou seja, os franqueados (POLO-REDONDO et al., 2011). Estas taxas trazem consigo 
parte da reputação, know-how, suporte e conhecimento das redes (DESAI, 1997; VASQUEZ, 2005). Ambos os termos podem ser utilizados como sinais de qualidade e de atratividade da rede e irão influenciar seu porte (SHANE et al., 2006).

A literatura relacionada ao balanceamento de taxas de franquia indica evidências de uma relação negativa entre destas taxas com o desempenho de franqueados (GALLINI; LUTZ, 1992; LAFONTAINE, 1992) e com o porte da rede (SHANE et al., 2006.). Ou seja, a elevação destas taxas envia um sinal negativo para potenciais franqueados.

Apesar da insatisfação de franqueados, estas taxas incentivam franqueadores a gerenciar a cadeia de forma eficiente (BHATTACHARYYA; LAFONTAINE, 1995). Elas aumentariam na medida em que a cadeia amadurece de forma motivar 0 franqueador (SHANE, 1998, 2001) e a compensar a demanda gerada pela reputação da rede. Em suma, com base nos modelos de risco moral bilateral, onde ambas as taxas são ajustadas para remunerar a parte contratual com maior produto marginal, ou seja, com maior importância relativa para o sucesso da operação. Considerando que a reputação e o valor da marca conseguem contribuir para elevação da demanda para os produtos da rede, espera-se então um maior valor destas taxas sendo praticadas por redes maduras mesmo durante seu crescimento. Assim:

H2c. Redes mais maduras conseguem elevar a taxa fixa inicial mesmo durante fases de crescimento.

H2d. Redes mais maduras conseguem elevar as taxas de royalties mesmo durante fases de crescimento. 


\subsection{Método de Análise}

A metodologia empregada neste estudo baseia-se em estratégias de combinação de métodos de análise multivariada e análise econométrica com certa recorrência nas literaturas de redes, franchising, ciclo de vida e grupos estratégicos.

Inicialmente, as redes são segregadas com base em atributos que decorrem da evolução alcançada ao longo de seu ciclo de vida. Como argumentado na Seção 3.8, na medida em que amadurecem e se consolidam as redes desenvolvem atributos específicos refletindo sua trajetória e moldando seu comportamento estratégico. Uma vez que tais atributos decorrem do processo de um processo amadurecimento, um alto nível de especificidade é esperado (path dependence), assim como maiores custos de mudança. Isso significa que grupos de redes com atributos similares apresentarão uma considerável consistência, já que existem barreiras de mobilidade em função da especificidade dos atributos característicos de cada grupo.

A pesquisa em franchising oferece exemplos de estudos analisando grupos de comportamento estratégico em um contexto bastante coerente com a dinâmica argumentada acima. Trabalhos anteriores identificando grupos estratégicos conseguiram obter uma taxonomia destes grupos através de análise fatorial, a qual permitiu identificar estruturas latentes nos dados das redes. Por exemplo, Carney e Gedajlovic (1991) empregam análise fatorial para identificar grupos de comportamento estratégicos entre 128 redes de franquia canadenses. Os autores compilam 13 variáveis relacionadas a 7 dimensões estratégicas distintas (porte, dispersão, crescimento, atratividade ao franqueado, provisões contratuais, mix contratual e ciclo de vida) para identificar uma taxonomia de grupos estratégicos quanto ao nível de integração vertical. Uma analise fatorial é empregada sobre as variáveis de interesse, obtendo-se cinco grupos. Uma MANOVA é aplicada para atestar a diferença entre os grupos. Após a identificação dos grupos, uma análise qualitativa é aplicada sobre o perfil do grupo com base nos valores assumidos pelas variáveis em cada grupo. 
Cataluña et al. (2007) replicam o trabalho de Carney e Gedajlovic (1991) no mercado espanhol. Partindo do mesmo conjunto de variáveis ${ }^{19}$, aplicou-se uma análise fatorial para identificação dos grupos entre 140 redes operando na Espanha. Os autores utilizam uma amostragem não aleatória, de forma a obter maior nível de homogeneidade nos resultados. Como resultado, quatro grupos são identificados: redes estáveis de alto investimento, redes maduras, redes de rápido crescimento e redes convertidas. Na sequência, os autores acrescentam cinco novas variáveis: (i) população mínima requerida (pelo franqueador), (ii) vendas totais na Espanha, (iii) área mínima da loja, (iv) setor da indústria e (v) estratégia de distribuição (mix contratual). Em resumo, os quatro grupos identificados inicialmente são consistentes, mesmo após a entrada das novas variáveis.

Martínez-Torres e Toral-Marin (2009) também aplicam um modelo semelhante sobre 500 redes de franquia operando nos EUA. No entanto, ao invés de derivar as variáveis da teoria, as autoras aplicam um método stepwise (Algoritmo Genético) para selecionar variáveis. O grupo original de variáveis pré-selecionadas (31 no total) é submetido ao algoritmo, o qual seleciona aquelas que com maior contribuição potencial na análise fatorial em termos de variância explicada. Após a extração dos fatores, as autoras procedem com análise descritiva dos grupos com base nas variáveis relevantes em cada grupo.

Pereira-Moliner et al. (2010) utilizam uma sequência de métodos similares aos empregados aqui para alcançar o que chamam de validade preditiva, isto é, modelos capazes de prever desempenho de uma empresa com base no grupo estratégico ao qual pertence. Através de análise fatorial são identificadas estratégias adotadas por hotéis na Espanha (cinco estratégias são identificadas). Após identificar as estratégias adotadas, uma análise fatorial é aplicada para identificar os grupos estratégicos (quatro grupos são identificados). Em seguida, uma ANOVA é aplicada para atestar diferenças em desempenho (cinco medidas de desempenho são testadas individualmente). Por fim, análises de regressão múltipla MQO são aplicadas por grupo para cada uma das cinco medidas de desempenho.

Por fim, Combs et al. (2004b) utilizam uma metodologia similar para identificar grupos estratégicos. Através de análise de agrupamento (cluster), 65 redes de

\footnotetext{
${ }^{19}$ Na verdade, a variável "Dispersão" usada em Carney e Gedajlovic (1991) foi substituída por "Internacionalização" no trabalho de Cataluña et al., (2007)
} 
franquia do ramo de alimentação e listadas em bolsa de valores são separada em três grupos com base em nível de experiência da rede com o setor de franquias, escassez de recursos, custos de monitoramento, necessidade de conhecimento local, custos de coordenação e dispersão. Os autores pioneiramente confrontam estes resultados a medidas de desempenho (ROI/ROE/ROA), identificando que as redes mais bem sucedidas são aquelas que conseguem minimizar custos de coordenação. O pior desempenho fica para aquelas redes cuja principal estratégia é usar franqueados para contornar restrições a recursos financeiros e gerenciais.

Em resumo, o uso da análise fatorial para objetivamente identificar uma taxonomia de grupos de comportamento tem sido recorrentes na pesquisa em franchising. Assim sendo, também nesta pesquisa este método será aplicado. Como mencionado, a amostra é submetida a uma análise fatorial para identificação dos grupos de comportamento. Para a identificação destes grupos, são usadas as mesmas dimensões empregadas em Carney e Gedjlovic (1991), Castrogiovanni et al. (1995) e Cataluña et al. (2007). No entanto, ao invés de limitar a análise ao comportamento das variáveis entre os grupos (o que também é feito), procura-se identificar o perfil típico das redes com relação ao estágio do ciclo de vida em que se encontram.

O objetivo da vinculação dos grupos ao ciclo de vida é o uso desta característica como variável moderadora na análise de crescimento que sucede a identificação dos grupos, conforme percebido na formulação das hipóteses declaradas na Seção 4.4. Um conjunto de técnicas econométricas é aplicado no sentido de identificar as variáveis que influenciam o crescimento de redes de franquia no Brasil. Detalhes da aplicação destes métodos serão dados no Capítulo 7.

Em suma, estas técnicas consistem de regressões lineares aplicadas individualmente sobre os grupos, as quais têm como variáveis explicativas as operacionalizações das hipóteses derivadas do risco na operação e dos mecanismos de incentivos relacionados à proposta de valor das redes (detalhes na Seção 5.6).

Porém, um cuidado adicional foi tomado. O crescimento do número de unidades da rede é assumido como um dos objetivos das redes de franquia 
enquanto empresas voltadas para o lucro. Assim sendo, tanto a formação dos grupos estratégicos descrita acima como os modelos de regressão criados para explicar o crescimento são constituídos por variáveis que refletem a intenção da rede em crescer. Em outras palavras, os fatores empregados na análise afetariam simultaneamente as escolhas da organização (estratégias, arranjos, etc.) e o desempenho alcançado por elas (crescimento, lucratividade, produtividade, etc.). Isto constitui um quadro de endogeneidade nos dados do qual resulta risco de viés nos resultados alcançados. Assim sendo, as próximas seções descrevem a metodologia empregada para contornar este problema nas regressões da segunda fase do estudo.

\subsection{Controle para Endogeneidade dos Dados}

Muitos fatores influenciam simultaneamente o desempenho e as escolhas organizacionais (CHAUDAY, FADAIRO, 2008). Por esta razão, a tomada de decisão é muitas vezes endógena com relação ao desempenho esperado. Em função disso, controles para problemas de endogeneidade e viés de seleção são necessários.

Lafontaine e Shaw (1999) identificam evidências de que regressões MQO usadas até então sofrem de viés de variáveis omitidas. Verificando o comportamento dos termos financeiros em contratos de franquia (royalties e taxas fixas de franquia), as autoras notam que, na ausência do controle para endogeneidade, os resultados dos testes MQO apontam para influencia do porte e maturidade na variação de taxas. No entanto, controlando para efeitos fixos das redes (porte e tecnologia, por exemplo) tal padrão não se sustentava. Ou seja, um comportamento padrão previsto pela teoria com relação a evolução de termos contratuais decorre na verdade de especificidades das firmas.

A aplicação da metodologia desenvolvida pelas teorias da firma para investigar o trade-off entre mercado e hierarquia exige assumir que as forças do mercado são fortes o suficiente para classificar de forma eficiente as escolhas quanto ao arranjo. Esta vertente teórica é voltada para o estudo dos custos de transações como o indutor de arranjos alternativos de organização da produção (governança), dentro de um arcabouço analítico institucional. 
No nível individual, apesar dos hipotéticos benefícios do alinhamento entre arranjo e desempenho, nem todas as empresas selecionam arranjos para governar as diversas transações de forma alinhada. A evidência empírica sugere que indivíduos nem sempre tomam decisões racionais em situações de incerteza. Eles frequentemente empregam processos heurísticos para lidar com a incerteza e estas heurísticas, muitas vezes, levam a distorções na tomada de decisão (YVRANDEBILLON; SAUSSIER, 2004).

Testes clássicos da decisão "make-or-buy" baseados em regressões probabilísticas ou logísticas (daqui em diante chamados de probit/logit) não avançaram o conhecimento quanto à importância da seleção do arranjo (MASTEN; SNYDER, 1993).

Se, por exemplo, forem considerados dois arranjos alternativos (por exemplo, loja própria versus loja franqueada) e denominando-os por $\beta_{1}$ e $\beta_{2}$, observa-se que modelos probit/logit geram coeficientes na forma $\left(\beta_{2}-\beta_{1}\right) / \sigma$, onde $\sigma^{2}$ é a variância do erro de um modelo comparando arranjos possíveis $\left(e_{1-} e_{2}\right)$. Assim, as previsões são baseadas no sinal de $\left(\beta_{2}-\beta_{1}\right)$, de forma que, quanto menos precisas forem as percepções do gestor, menor será o efeito estimado de das características da transação. Reciprocamente, quanto mais impreciso o processo de seleção, menos importante será o efeito do arranjo escolhido para os testes empíricos.

A primeira geração desses estudos consistiu em descobrir as fontes das dificuldades de contratação para, então, analisar seu impacto sobre a escolha do arranjo (reconhecendo, portanto, a natureza endógena das escolhas organizacionais). Já a segunda fase da pesquisa busca identificar as várias maneiras de testar a hipótese do desalinhamento entre arranjo e desempenho. As duas principais metodologias que ilustram 0 impacto do desempenho de desalinhamento são discutidas: o método de Heckman $(1974,1976)$ e a construção da variável do desalinhamento.

\subsection{Inadequações dos Modelos Tradicionais}

Como mencionado, os primeiros modelos voltados para entendimento de arranjos de governança com base em custos de coordenação apresentavam sérias limitações estruturais. Segundo Masten (1994), tais modelos eram normalmente 
baseados em regressões do tipo logit/probit (ou seja, variáveis dependentes dicotômicas relacionadas à decisão "make-or-buy") e apresentavam a seguinte estrutura:

$$
\begin{aligned}
A^{*} & =A^{1}, \text { se } C 1^{1}<C^{2}(1) \\
& =\mathrm{A}^{2}, \text { se } C 1^{1} \geq \mathrm{C}^{2}(2)
\end{aligned}
$$

Sendo:

- $\mathrm{A}^{*} \mathrm{o}$ arranjo escolhido

- $\mathrm{A}^{1}$ e $\mathrm{A}^{2}$ os arranjos alternativos

- $\mathrm{C}^{1}$ e $\mathrm{C}^{2}$ os custos alternativos relativos a cada arranjo possível

Dessa modelagem decorrem alguns problemas não contornáveis. Custos de coordenação (no sentido dos custos de transação de Williamson [1985]) são difíceis de observar e medir. Por exemplo, riscos potenciais ex post relacionados a litígios em tribunais são uma realidade no estabelecimento de arranjos alternativos à integração vertical como joint ventures e contratos de franquia. No entanto, mensurar tais riscos de forma exata não é possível.

Porém, a questão primordial centra-se na impossibilidade de comparar arranjos alternativos. Ou seja, uma vez escolhido o arranjo, abdica-se de todos os demais, de forma que a comparação não é possível.

A literatura têm desenvolvido métodos para o desenvolvimento de hipóteses refutáveis (AQUINO, 2005). As duas principais metodologias consistem em (1) identificar como as características distintivas de cada arranjo afetam os custos associados a sua adoção e (2) relacionar de forma discriminante a incidência destes custos a dimensões observáveis da transação.

Por exemplo, redes franqueadas ocupam um vasto espectro de indústrias, oferecendo ao público produtos diversos, tais como hotelaria, aluguel de veículos ou hambúrgueres. Estes produtos variam em termos de complexidade de atributos, nível de automação nas lojas, dentre outros. É possível inferir que quanto mais complexos e variados forem tais atributos, maior a dificuldade de monitoramento e mensuração de desempenho, o que constitui uma hipótese testável. Ou seja, é 
possível, a princípio, buscar relacionar a adoção ou não de contratos de franquia em diferentes setores da economia com base em atributos da transação.

Formalmente:

$$
\begin{aligned}
& C^{1}=\beta_{1} X+e_{1}(3) \\
& C^{2}=\beta_{2} X+e_{2}(4)
\end{aligned}
$$

Neste caso, X representa o vetor de atributos observáveis da transação e $\beta_{1} / \beta_{2}$ são vetores de parâmetros (coeficientes). Os termos $\mathrm{e}_{1} \mathrm{e} \mathrm{e}_{2}$ são fatores não observáveis relativos ao arranjo em questão, tais como erros do processo decisório ou má intepretação do contratante com relação aos atributos, por exemplo.

As equações (3) e (4) podem ser estimadas separadamente utilizando subamostras de empresas que optaram por $A^{1}$ e $A^{2}$ respectivamente. Assim, o efeito médio dos atributos da transação seria então dado por $X\left(\beta_{2}-\beta_{1}\right)$. No entanto, a estimação destas equações para captar efeitos do arranjo somente se aplica quando todos os fatores que afetam o desempenho e a escolha do arranjo são observáveis e incluídos nas regressões, o que raramente é possível (HAMILTON; NICKERSON, 2003). Isso gera um problema potencial de endogeneidade ao estimar equações (3) e (4).

Desenvolvendo as equações (3) e (4) tem-se que:

$$
\begin{aligned}
& E\left(C^{1} \mid A^{1}, X\right)=E\left(\beta_{1} X+e_{1} \mid A^{1}\right)=\beta_{1} X+E\left(e_{1} \mid A^{1}\right) \\
& E\left(C^{2} \mid A^{2}, X\right)=E\left(\beta_{2} X+e_{2} \mid A^{2}\right)=\beta_{2} X+E\left(e_{2} \mid A^{2}\right)
\end{aligned}
$$

Em suma, é pouco válido medir os efeitos da escolha do arranjo organizacional sobre o desempenho da firma com base nos atributos da transação apenas sem considerar o termo de erro da estimativa, na medida em que este contém a variância não observada da qualidade da tomada de decisão. Especificamente, os coeficientes do modelo da escolha qualitativa assumem a forma $\left(\beta_{2}-\beta_{1}\right) / \sigma$, onde $\sigma^{2}$ é a variância de $\left(\mathrm{e}_{1-} \mathrm{e}_{2}\right)$.

Assim, mesmo se o modelo compreendesse todas as variáveis que influenciam a decisão organizacional, os efeitos estimados dessas variáveis 
dependeriam da medida com que os erram na tomada de decisão, ou seja, da magnitude de $\mathrm{e}_{1}$ e $\mathrm{e}_{2}$.

Quanto menos preciso o entendimento dos custos específicos de uma alternativa de arranjo organizacional (quanto maior $\sigma$ ), menor será o efeito estimado de um determinado atributo sobre a probabilidade de escolha. Reciprocamente, pequenos riscos potenciais inerentes de arranjos alternativos terão grande influência sobre a decisão de escolha se a tomada de decisão for otimizadora. Em resumo, a ausência de informação adicional (o termo de erro) impede que se infira qualquer conclusão a partir de testes empíricos do tipo $C=\beta X+\mathrm{e}$.

Diante disso, a pesquisa em torno da relação entre arranjo organizacional e desempenho corre riscos de especificação. A abordagem mais comum é avaliar os efeitos do arranjo escolhido sobre o desempenho regredindo-se alguma medida de desempenho contra atributos da transação:

$$
D=\alpha X+\gamma G+e
$$

Onde D representa desempenho, A representa um arranjo específico e X um grupo de atributos da transação em questão. O coeficiente $\gamma$ é interpretado como a contribuição dada pelo arranjo escolhido para o desempenho da firma.

O problema mais frequente com esse tipo de formulação é que ela restringe a análise a um único arranjo, independente dos atributos da transação. Uma vez que o cotidiano indica um espectro de arranjos possíveis, inclusive com diferentes níveis de intensidade de controle organizacional, a variação entre arranjos não é representada e $\gamma$ não terá significado.

Uma especificação alternativa verificada em alguns estudos (YVRANDEBILLON; SAUSSIER, 2004) permite que potenciais trade-off na escolha do arranjo incorporem uma interação entre o arranjo e variáveis relacionadas a atributos da transação. Formalmente:

$$
D=\alpha X+\gamma_{0} G+\gamma_{1}(G X)+e
$$

Ou ainda, uma formulação equivalente estimando equações separadas para o desempenho de cada arranjo. 


$$
D_{i}=\alpha_{i} X+e_{i}
$$

Diferentemente da equação (7), as equações (8) e (9) permitem curvas próprias (com respectivas inclinações e interceptos) para cada arranjo. Entretanto, um problema de viés de seleção permanece. De acordo com o racional desenvolvido, para uma determinada população de transações a equação $\mathrm{D}_{1}=$ $\alpha_{1} \mathrm{X}+\mathrm{e}_{1}$ seria representativa. No entanto, $\mathrm{D}_{1}$ só é observado para aquelas transações para as quais $A_{1}$ é escolhido. Assim, o valor esperado de $D_{1}$ na amostra será $\beta_{1} X+E\left(e_{1} \mid A^{*}=A^{1}\right)$.

Se os gerentes optam pelo arranjo de forma randômica $E\left(e_{1} \mid A^{*}=A^{1}\right)$ será igual a zero e a estimação das equações fornecerá estimativas consistentes com o efeito do arranjo escolhido sobre o desempenho. No entanto, se os atores escolhem o arranjo de forma sistemática, o que é bem mais realístico, $E\left(\varepsilon_{1} \mid G^{*}=G^{1}\right)$ será diferentes de zero. Especificamente, onde o arranjo é escolhido para maximizar o desempenho, tem-se que:

$$
E\left(e_{1} \mid A^{*}=A^{1}\right)=E\left(e \mid D_{1}>D_{2}\right)=E\left(e_{1} \mid e_{1}-e_{2}>\left(\alpha_{2}-\alpha_{1}\right) X\right)
$$

O modelo irá gerar uma estimativa com viés dos efeitos do arranjo e pode fazer com que os atributos da transação pareçam significantes quando de fato não influenciam o desempenho da firma. Ou seja, os verdadeiros fatores de influência estão nos aspectos não observáveis da tomada de decisão.

É usual supor a existência de variáveis não observáveis que afetam o desempenho resultante e que são correlacionadas com a escolha arranjo. Também é natural acreditar que uma empresa que escolhe $\mathrm{A}_{2}$ pode diferir de uma empresa selecionada aleatoriamente da população de empresas. Como explicado por Hamilton e Nickerson (2003), a abordagem de estimação depende de se tais variáveis não observáveis existem e se as escolhas organizacionais são endógenas ou não. Se nem todas as variáveis que afetam o desempenho e as escolhas organizacionais são conhecidas ou se as escolhas organizacionais não são exógenas, então, usar procedimentos OLS para estimar as equações (8) e (9) poderia levar a um potencial problema de endogeneidade. 
Uma vez que problemas associados à estimação dos efeitos do arranjo sobre o desempenho derivam da seleção sistemática do arranjo pelas firmas, duas soluções são possíveis para lidar com este problema de viés de seleção. A primeira consiste em neutralizar um pouco o processo de seleção do arranjo. Para anular o processo de seleção poder-se-ia, por exemplo, conduzir experimentos controlados nas quais o arranjo é randomicamente designado para a transação. Variar o arranjo em experimentos do mundo real é provavelmente difícil e custoso, contudo, experimentos em laboratório provavelmente poderiam captar a complexidade que torna as escolhas organizacionais problemáticas.

\subsection{O Método de Heckman}

Pelo menos desde 1974 a literatura vem fornecendo técnicas econométricas para corrigir problemas de endogeneidade resultante de escolhas discretas de estratégias (HECKMAN, 1974; HAMILTON; NICKERSON, 2003). O estudo pioneiro de Heckman (1974) proveu muitos estimadores econométricos desenvolvidos no contexto da economia do trabalho.

No entanto, o problema do trade-off "trabalho versus lazer" desta literatura permite projetar o modelo de Heckman para outros modelos de decisão com a mesma estrutura discreta, como por exemplo, a decisão de "make-or-buy". A técnica de Heckman é baseada na suposição de que os indivíduos se auto selecionam para a profissão que lhes proporciona maior adequação de suas habilidades e, consequentemente, um maior retorno. Entretanto, se essa auto seleção não for modelada, uma regressão da renda do indivíduo sobre a escolha profissional pode levar a estimativas erradas dos retornos gerados por cada profissão.

Ou seja, os dados de escolaridade, preferências pessoais e outros só eram divulgados por indivíduos presentes no mercado de trabalho. Indivíduos que estão fora do mercado podem estar nesta condição por questões ligadas a sua função utilidade de querer ou não trabalhar, por exemplo. Dessa forma modelos com esta estrutura são construídos a partir de uma subamostra e projetados indevidamente para a amostra completa.

Projetando esta discussão para escolhas discretas quanto ao arranjo de governança, esta alternativa oferece potencial para avaliar a importância da 
governança sob circunstâncias mais gerais. Yvrande-Billon e Saussier (2004) e Sampson (2004) sugerem o uso do método de Heckman para controlar o problema de endogeneidade e viés de seleção.

A aplicação da solução de Heckman tem dois pressupostos fundamentais. Em primeiro lugar, a escolha do arranjo é modelada como uma variável latente contínua (por exemplo, $A^{*}$ ), o que implica que $A^{1}$ será escolhido se $A^{*}$ supera um determinado valor limite (threshold). Caso contrário, $A^{2}$ será escolhido. O segundo pressuposto é que os termos de erro das equações são normalmente distribuídos e não correlacionados.

Através de modelos probit/logit é possível o valor de referência para $A^{*}$, o qual determinará se $A^{1}$ ou $A^{2}$ será escolhido. Uma vez que a variável resposta é a probabilidade de ocorrência do fenômeno, caberá ao pesquisador determinar o limite mínimo aceito de probabilidade. No caso de mais de uma possibilidade em termos de arranjo, soluções multinominais (mlogit ou mprobit) deverão ser aplicadas, conforme sugerido por Hamilton e Nickerson (2003).

A abordagem sugerida por Heckman (1979) e aprimorada por Lee (1982) consiste de uma estimação de dois estágios na qual os resultados da estimação da escolha do arranjo são usados para controlar o viés de seleção em equações estruturais. Seguindo a notação adotada anteriormente, pode-se reescrever $E\left(\varepsilon_{1} \mid\left(\beta_{2}-\beta_{1}\right) X\right)$ como:

$$
\lambda=\rho_{\eta} \frac{\phi\left[\left(\beta_{2}-\beta_{1}\right) X\right]}{\Phi\left[\left(\beta_{2}-\beta_{1}\right) X\right]}
$$

Onde $\phi$ é a função densidade normal padrão e $\Phi$ a função densidade acumulada. Além disso, $\sigma_{\eta 1}$ é a covariância entre $\left(e_{1}-e_{2}\right)$ e $e_{1}$. O efeito de seleção sobre o termo de erro por esta estimativa pode ser controlado estimando-se:

$$
D=\alpha_{1} X+\sigma_{\eta 1} \lambda
$$


Onde $\lambda$ também conhecido como a razão inversa de Mills (SAMPSON, 2004). Nesse contexto, um modelo de escolha de governança do tipo usado em estudos de custos de transação seria primeiramente estimado e os resultados usados para estimar $\lambda$, o qual seria então usado para estimar parâmetros da equação do desempenho correspondente para cada arranjo alternativo. A partir destes parâmetros, o desempenho estimado de cada arranjo alternativo, dados os atributos da transação, poderia ser calculado e comparado.

A correção do viés de seleção e da endogeneidade das escolhas organizacionais sugere que o pesquisador tenha uma ou mais variáveis instrumentais que afetam as escolhas estratégicas, mas não afetam diretamente o desempenho.

Frisa-se que a variável instrumental deve estar correlacionada com as variáveis endógena, mas não pode estar correlacionada com o termo de erro. Ou seja, o instrumento não pode sofrer o mesmo problema que a variável original para a qual ele servirá de instrumento. Uma vez que o termo de erro não é observável, uma forte argumentação teórica é necessária para justificar o instrumento. De fato, é difícil encontrar variáveis instrumentais que afetam as escolhas estratégicas, mas é factível identificar variáveis que afetam o desempenho. Uma solução prática é dotar a regressão estruturada para calcular a razão inversa de Mills com mais variáveis do que as regressões aplicadas para explicar o desempenho (WOOLDRIDGE, 2006, p. 527). 


\section{DADOS E VARIÁVEIS}

A seguir são detalhadas as fontes de informação usadas na pesquisa, bem como a forma de o método de coleta destes dados.

\subsection{Guia de Franquias da ABF}

A primeira fonte utilizada para montagem da base de dados foi o Guia Oficial de Franquias 2011 da Associação Brasileira de Franchising (ABF). O Guia visa divulgar ao público interessado informações sobre as diversas redes associadas, bem como de outros participantes deste setor. Estão contidas informações com relação ao ramo de atividade das redes, tamanho, valor do investimento requerido, dentre outros.

Entrevistas com executivos da associação permitiram entender a forma como a ABF divulga estas informações. A alimentação de informações para publicação do Guia ABF é feita pelas próprias redes associadas. A ABF dispõe de um sistema informativo interno acessado pelas redes associadas, as quais tem liberdade para efetuar atualizações de informações em tempo real. As redes tem interesse em manter informações atualizadas, visto ser o Guia uma ferramenta de comunicação com franqueados potenciais. Estas informações são usadas em todas as publicações patrocinadas pela $A B F$, o que inclui o Guia Oficial de Franquia $A B F$, a Revista Franquia ABF, o Guia Internacional ABF, dentre outros.

A atualização das informações é facultativa, mas seu caráter público incentiva as redes a manterem os dados atualizados. Uma vez que o Guia ABF constitui um dos primeiros canais de comunicação entre franqueador e franqueado, seriam esperados danos à reputação das redes caso transmitissem ao mercado informações básicas divergentes de sua realidade.

As diversas publicações da ABF são precedidas de análise da variação anual das informações alimentadas pelas redes, o que constitui uma constante análise de consistência de destes dados. Variações fora de uma normalidade (subjetiva) são questionadas diretamente ao associado em questão. 
A $A B F$ ainda não dispõe de um conselho científico fixo, de forma que o acompanhamento e validação destas informações são conduzidos pela Gerência de Relacionamento da organização. Eventualmente, em trabalhos mais específicos, consultorias especializadas são contratadas.

\subsection{Outras Fontes de Informação}

Como forma de complementar as informações do Guia ABF, foram coletadas informações a partir dos endereços de internet das redes da amostra. Foram coletadas informações de CEP das cidades ocupadas pelas redes, bem como se as lojas estão estabelecidas em algum tipo de centro comercial.

A coleta de dados ocorreu entre os meses de abril e julho de 2011. Em algumas redes ocorreu certa diferença no número total de lojas coletadas nos sites de internet e o número de redes divulgados no Guia ABF. Optou-se por acatar a quantidade de lojas divulgadas no anuário.

Por fim, procedeu-se uma estabilização da base de dados, pois nem todas as 728 redes divulgam todas as informações necessárias ao estudo. Além disso, como será visto adiante, precisou-se que algumas informações das redes também estivessem disponíveis em anuários dos anos anteriores para captar efeitos dinâmicos (detalhes na Seção 5.4).

Assim, após verificar quais eram as redes que simultaneamente disponibilizavam informações nas edições do Guia ABF entre 2009 e 2001e os endereços das lojas, obteve-se uma amostra de 376 redes de franquia. Esse número considera aqueles casos em que foi necessário a recorrer a outras fontes de informação para preencher valores perdidos (missing values), como por exemplo, o site da publicação Pequenas Empresa Grandes Negócios ${ }^{20}$. Frisa-se que menos de $1 \%$ dos dados precisou receber tal tratamento.

\footnotetext{
${ }^{20}$ Os sites das redes também auxiliaram ao preenchimento de valores perdidos.
} 


\subsection{Amostra}

Algumas redes de percebida importância não são associadas à $A B F$, tais como a rede de pizzarias Pizza Hut, a Unidas Rent a Car, Chlorophylla Perfumes e a rede Drywash (todas com mais de 100 unidades no país). Assim, torna-se necessária uma análise quanto ao viés da amostra em relação à população de redes de franquia no Brasil. Embora não tenham sido obtidas informações mais detalhadas que permitisse comparar redes associadas daquelas que não fazem parte dos quadros da $A B F$, algumas informações consolidadas do setor permitem analisar população e amostra.

Para checar a representatividade da amostra frente à população de redes de franquia no Brasil, os dados tabulados foram comparados a informações disponíveis sobre franchising no Brasil. Anualmente a ABF divulga através de seus canais de comunicação estudos sobre a evolução do setor de franquias no país. Um dos estudos dispõe dados consolidados do faturamento total, número de unidades e número de redes de franquia, sendo que as três informações são segmentadas por área de atuação. Este estudo elenca informações para todo o setor de franchising, incluindo as redes não associadas.

A Tabela 1 contém uma comparação entre segmentos de atuação de redes de franquia em três níveis de dados: dados consolidados para o setor retirados de estudos da $A B F$, dados de todas as redes que divulgam informações no Guia Oficial de Franquias e dados da amostra derivada do próprio Guia. São três números analisados na comparação: faturamento das redes em 2010, número total de unidades de negócio (próprias e franqueadas) e número de redes franqueadas operando no país.

Além dos valores para cada Grupo das três categorias analisadas, foram inseridos valores percentuais indicando a representatividade de cada área de atuação frente ao conjunto total de segmentos. Por exemplo, o faturamento do setor de alimentação representa $20,1 \%$ do faturamento total para o setor de franchising no estudo da ABF (ou 13,9\% do faturamento das redes do Guia Oficial de Franquias ou $23 \%$ da amostra aqui utilizada). 
Tabela 1 - Proporções dos segmentos de franquias no Brasil, entre as redes associadas à ABF e entre as redes da amostra (fonte: ABF)

\begin{tabular}{|c|c|c|c|c|c|c|c|c|c|c|c|c|c|c|c|c|c|c|}
\hline \multirow{3}{*}{$\begin{array}{c}\text { Segmentos } \\
\text { Classificação ABF }\end{array}$} & \multicolumn{6}{|c|}{$\begin{array}{l}\text { Faturamento do Setor } \\
\text { (em Milhões de Reais) }\end{array}$} & \multicolumn{6}{|c|}{$\begin{array}{l}\text { Número Total } \\
\text { de Unidades }\end{array}$} & \multicolumn{6}{|c|}{$\begin{array}{l}\text { Número de } \\
\text { Redes de Franquia }\end{array}$} \\
\hline & \multicolumn{2}{|c|}{ Setor } & \multicolumn{2}{|c|}{$A B F$} & \multicolumn{2}{|c|}{ Amostra } & \multicolumn{2}{|c|}{ Setor } & \multicolumn{2}{|c|}{ ABF } & \multicolumn{2}{|c|}{ Amostra } & \multicolumn{2}{|c|}{ Setor } & \multicolumn{2}{|c|}{ ABF } & \multicolumn{2}{|c|}{ Amostra } \\
\hline & $\mathbf{R} \$$ & $\%$ & $\mathbf{R} \$$ & $\%$ & $\mathbf{R} \$$ & $\%$ & Un. & $\%$ & Un. & $\%$ & Un. & $\%$ & Rede & $\%$ & Rede & $\%$ & Rede & $\%$ \\
\hline Alimentação & 15.288 & 20,1 & 9.894 & 23,1 & 8.094 & 35,3 & 12.015 & 13,9 & 9.832 & 19,6 & 8.272 & 29,9 & 427 & 23,0 & 188 & 25,8 & 129 & 34,3 \\
\hline Saúde, Beleza e Lazer & 11.842 & 15,6 & 10.045 & 23,4 & 4.368 & 19,1 & 15.543 & 18,0 & 12.277 & 24,4 & 5.300 & 19,2 & 320 & 17,3 & 126 & 17,3 & 73 & 19,4 \\
\hline Educação e Treinamento & 5.470 & 7,2 & 5.253 & 12,2 & 3.451 & 15,1 & 12.835 & 14,9 & 10.151 & 20,2 & 7.282 & 26,3 & 219 & 11,8 & 85 & 11,7 & 53 & 14,1 \\
\hline Acessórios e Calçados & 4.842 & 6,4 & 3.490 & 8,1 & 3.315 & 14,5 & 4.178 & 4,8 & 3.238 & 6,4 & 3.145 & 11,4 & 134 & 7,2 & 62 & 8,5 & 46 & 12,2 \\
\hline Vestuário & 6.581 & 8,7 & 2.641 & 6,2 & 1.580 & 6,9 & 5.073 & 5,9 & 2.505 & 5,0 & 1.444 & 5,2 & 220 & 11,9 & 72 & 9,9 & 39 & 10,4 \\
\hline Negócios e Serviços & 20.960 & 27,6 & 4.677 & 10,9 & 325 & 1,4 & 22.672 & 26,3 & 4.822 & 9,6 & 455 & 1,6 & 198 & 10,7 & 80 & 11,0 & 9 & 2,4 \\
\hline Foto, Gráficas e Sinalização & 1.492 & 2,0 & 168 & 0,4 & 131 & 0,6 & 1.907 & 2,2 & 94 & 0,2 & 73 & 0,3 & 19 & 1,0 & 7 & 1,0 & 5 & 1,3 \\
\hline Informática e Eletrônicos & 1.092 & 1,4 & 547 & 1,3 & 44 & 0,2 & 1.713 & 2,0 & 888 & 1,8 & 67 & 0,2 & 76 & 4,1 & 23 & 3,2 & 4 & 1,1 \\
\hline Veículos & 2.763 & 3,6 & 1.611 & 3,8 & 459 & 2,0 & 4.176 & 4,8 & 2.496 & 5,0 & 595 & 2,2 & 72 & 3,9 & 28 & 3,8 & 4 & 1,1 \\
\hline Hotelaria e Turismo & 1.493 & 2,0 & 1.414 & 3,3 & 570 & 2,5 & 672 & 0,8 & 434 & 0,9 & 152 & 0,5 & 25 & 1,3 & 10 & 1,4 & 4 & 1,1 \\
\hline Limpeza e Conservação & 649 & 0,9 & 648 & 1,5 & 241 & 1,1 & 1.975 & 2,3 & 1.223 & 2,4 & 674 & 2,4 & 56 & 3,0 & 24 & 3,3 & 7 & 1,9 \\
\hline Móveis e Decoração & 3.515 & 4,6 & 2.532 & 5,9 & 339 & 1,5 & 3.606 & 4,2 & 2.269 & 4,5 & 197 & 0,7 & 89 & 4,8 & 23 & 3,2 & 3 & 0,8 \\
\hline TOTAL & 75.987 & 100,1 & 42.920 & 100,1 & 22.916 & 100,2 & 86.365 & 100,1 & 50.229 & 100,0 & 27.656 & 99,9 & 1.855 & 100,0 & 728 & 100,1 & 376 & 100,1 \\
\hline
\end{tabular}


Tabela 2 - Comparação do setor de Franquias no Brasil com redes associadas à ABF e amostra (fonte: ABF)

\begin{tabular}{l|c|c|c|c|c|c|c|c|c|}
\hline \multirow{2}{*}{$\begin{array}{c}\text { Segmentos } \\
\text { Classificação ABF }\end{array}$} & \multicolumn{3}{c|}{ Faturamento (\%) } & \multicolumn{2}{c|}{ Total de Unidades (\%) } & \multicolumn{2}{c|}{ Redes de Franquia (\%) $^{*}$} \\
\cline { 2 - 9 } & Setor & ABF & Amostra & Setor & ABF & Amostra & Setor & ABF & Amostra \\
\hline Alimentação & 20,1 & 13 & 10,7 & 13,9 & 11,4 & 9,6 & 23 & 10,1 & 7 \\
Saúde, Beleza e Lazer. & 15,6 & 13,2 & 5,7 & 18 & 14,2 & 6,1 & 17,3 & 6,8 & 3,9 \\
Educação e Treinamento & 7,2 & 6,9 & 4,5 & 14,9 & 11,8 & 8,4 & 11,8 & 4,6 & 2,9 \\
Acessórios e Calçados & 6,4 & 4,6 & 4,4 & 4,8 & 3,7 & 3,6 & 7,2 & 3,3 & 2,5 \\
Vestuário & 8,7 & 3,5 & 2,1 & 5,9 & 2,9 & 1,7 & 11,9 & 3,9 & 2,1 \\
Negócios e Serviços & 27,6 & 6,2 & 0,4 & 26,3 & 5,6 & 0,5 & 10,7 & 4,3 & 0,5 \\
Limpeza e Conservação & 0,9 & 0,9 & 0,3 & 2,3 & 1,4 & 0,8 & 3 & 1,3 & 0,4 \\
Foto, Gráficas e Sinalização. & 2 & 0,2 & 0,2 & 2,2 & 0,1 & 0,1 & 1 & 0,4 & 0,3 \\
Móveis e Decoração & 4,6 & 3,3 & 0,4 & 4,2 & 2,6 & 0,2 & 4,8 & 1,2 & 0,2 \\
Informática e Eletrônicos & 1,4 & 0,7 & 0,1 & 2 & 1 & 0,1 & 4,1 & 1,2 & 0,2 \\
Veículos & 3,6 & 2,1 & 0,6 & 4,8 & 2,9 & 0,7 & 3,9 & 1,5 & 0,2 \\
Hotelaria e Turismo & 2 & 1,9 & 0,8 & 0,8 & 0,5 & 0,2 & 1,3 & 0,5 & 0,2 \\
\hline
\end{tabular}

* Proporção percentual entre a estatística para o setor na amostra em comparação à estatística do setor na população

Tabela 3 - Correlação de Pearson entre redes no Setor, redes associadas à $A B F$ e redes na amostra (fonte: $A B F$ )

\begin{tabular}{|c|c|c|c|}
\hline & Setor & $\begin{array}{c}\text { Guia } \\
\text { ABF 2011 }\end{array}$ & Amostra \\
\hline \multicolumn{4}{|l|}{ Faturamento } \\
\hline $\begin{array}{l}\text { Setor } \\
\text { Guia ABF } 2011 \\
\text { Amostra }\end{array}$ & $\begin{array}{l}1 \\
0,73 \\
0,49\end{array}$ & $\begin{array}{l}1 \\
0,87\end{array}$ & 1 \\
\hline $\begin{array}{l}\text { Número de Unidades } \\
\text { Setor } \\
\text { Guia ABF } 2011 \\
\text { Amostra }\end{array}$ & $\begin{array}{l}1 \\
0,74 \\
0,49\end{array}$ & $\begin{array}{l}1 \\
0,89\end{array}$ & 1 \\
\hline $\begin{array}{l}\text { Número de Redes } \\
\text { Setor } \\
\text { Guia ABF } 2011 \\
\text { Amostra }\end{array}$ & $\begin{array}{l}1 \\
0,99 \\
0,92\end{array}$ & $\begin{array}{l}1 \\
0,95\end{array}$ & \multirow[t]{2}{*}{1} \\
\hline Significante a $1 \%$ & & & \\
\hline
\end{tabular}


Tanto o número de redes quanto o número de unidades totais das redes foram simplesmente tabulados com base nos dados do Guia ABF. Para faturamento médio por unidade os dados não informados por algumas redes foram aproximados pela média do setor ${ }^{21}$.

A Tabela 2 indica a representatividade do Guia ABF e da amostra ante os números consolidados para o Setor de franchising no Brasil. Ou seja, a proporção percentual por segmento para cada uma das três variáveis é comparada ao número total do Setor como um todo 22 .

Por exemplo, considerando-se o segmento de Acessórios e Calçados, nota-se que o mesmo representa $6,4 \%$ do faturamento de todas as redes de franquia do Brasil. Se consideradas apenas as redes deste segmento representadas no Guia ABF 2011, elas representam $4,6 \%$ do faturamento de todas as redes brasileiras. Finalmente, se consideradas apenas as redes da amostra, a proporção do faturamento deste setor no total da amostra é de $4,4 \%$.

Para as três variáveis - faturamento, número de unidades e número de redes - nota-se que uma super-representação dos segmentos de Alimentação, Acessórios \& Calçados e Educação \& Treinamento tanto no Guia ABF 2011 como na amostra ${ }^{23}$. Por outro lado, redes dos segmentos Móveis \& Decoração, e Negócios \& Serviços estão sub-representadas na amostra. Isso pode possivelmente ter relação com o fato deste tipo de firma não precisar investir em reputação ou mesmo não querer se submeter à regulação, mesmo do tipo ordenação privada.

De forma consolidada, a amostra cobre aproximadamente $20 \%$ das redes de franquia do Brasil. No entanto, a amostra abrange mais de $32 \%$ do total de unidades e $30 \%$ do faturamento. Estes dados indicam algum viés da amostra, dando a entender que as redes de maior porte são associadas à ABF com mais frequência em relação às de menor porte.

${ }^{21}$ Para cada setor foi identificada a média do faturamento mensal por loja. Em seguida, multiplicou-se esse valor pelo número de unidades e pelo número de redes do setor (para a amostra e para o Guia ABF 2011 completo). Dessa forma, aproxima-se o valor do faturamento total para posterior análise comparativa.

${ }_{22}$ Frisam-se ainda os dados agregados do setor fornecidos pela ABF, referentes ao ano de 2010, enquanto o Guia ABF que forneceu a amostra refere-se ao ano de 2011, havendo assim certa imprecisão no cotejamento entre os dados, a qual se assume ser desprezível para análise com números consolidados e/ou aproximados como esta.

${ }^{23}$ Exceto para o número de redes no segmento Educação \& Treinamento. 
Para esta pesquisa, infelizmente não foi possível acessar dados do porte de redes não associadas de forma a traçar uma comparação. De qualquer forma, o viés da amostra limita a capacidade de generalização da pesquisa. Frisa-se, porém, que este não é um obstáculo mais sério aos objetivos da pesquisa, uma vez que a principal proposta aqui é analisar as diferentes dimensões do fenômeno franquia, considerando que fazem parte da amostra as maiores redes atuantes no Brasil.

Uma análise adicional foi conduzida para fins de consistência entre amostra e população. A Tabela 3 indica análise de correlação de Pearson entre os percentuais do setor. Lembrando que a correlação de Pearson indica a covariância padronizada entre variáveis, verifica-se que apesar de não ser observada concentração da amostra em um ou outro setor em relação ao Número de Redes, observa-se que quando analisado o Faturamento e Número de Unidades, a amostra, apesar de representar as redes associadas à ABF (ou seja, perda de redes por falta de dados não gera viés de amostra), não representa plenamente o setor de Franquias no Brasil. Isto se justifica pela própria ABF não abranger plenamente tal segmento em distribuição e número de associados.

Com isto, pode-se dizer que a amostra representa a população associada à $A B F$. E que a associação ABF é menos representativa de redes de menor porte e nos segmentos menos tradicionais de franquias no Brasil.

\subsection{Dados de Dispersão}

Como mencionado anteriormente, a análise considera aspectos das cidades atendidas pelas redes da amostra. Para levantamento destes dados foi acessado o site do Instituto Brasileiro de Geografia e Estatística (IBGE), o qual divulga nos dados do último Recenseamento Demográfico (2010) informações dos municípios brasileiros como área, população e renda. Estas informações serão utilizadas para verificar efeitos do padrão de dispersão destas redes. 


\subsection{Efeitos Temporais}

Embora essa análise seja transversal (cross-sectional) em relação ao ano de 2011, foram tabulados os dados das edições do Guia Oficial de Franquias da ABF entre 2002 e 2011. O objetivo, além do tratamento de valores perdidos (ver Seção 5.3), foi construir variáveis que captassem aspectos dinâmicos de determinadas variáveis. Por exemplo, a análise estática da proporção de lojas franqueadas pode omitir uma tendência de queda ou elevação desta proporção.

Todas as variáveis empregadas na análise de componente principal representam uma condição instantânea estática daquelas redes, quando da ocasião da coleta de dados. No entanto, é útil para a análise captar aspectos dinâmicos da evolução das redes como, por exemplo, a forma pela qual a evolução do mix contratual ao longo do tempo se relaciona com o crescimento das redes ${ }^{24}$.

Com base nas informações do Guia ABF (edições 2009 a 2011), coletou-se os dados históricos de variáveis como o número total de unidades ou mix contratual, por exemplo. Obviamente, nem todas as redes que apresentam esta informação em todas as edições do Guia, de forma que somente foram consideradas na análise aquelas redes que fornecem esta informação em, no mínimo, duas edições Guia.

\subsection{Informações Complementares}

O uso de dados secundários como evidência em um processo de argumentação acarreta riscos de viés e limitações quanto à validade de construto. Ou ainda, nas palavras de Booth et al. (1995), dados secundários não são uma evidência em si, mas sim um relato de uma evidência. Ou seja, ao contrário do que ocorre em pesquisas baseadas em estudos de caso, por exemplo, não é possível um maior aprofundamento nas especificidades do fenômeno, dado a relativa distância entre a realidade e a informação contida nos dados. Por outro lado, dados secundários permitem alcançar um entendimento mais abrangente o fenômeno.

\footnotetext{
${ }^{24}$ Frisa-se que nem todas as variáveis empregadas na análise de componente principal apresentam dados históricos, de forma que a inserção desta dinâmica neste procedimento estatístico estaria buscando agrupar variâncias desconectadas do ponto de vista temporal. Assim, enquanto o perfil estático das variáveis ajudou a segregar os grupos estratégicos através da análise fatorial, o perfil dinâmico de algumas destas variáveis auxiliou interpretar algumas relações latentes não captadas pelos fatores.
} 
Para lidar com a relativa perda de aderência entre os dados e a realidade além dos dados secundários acima mencionados, foram realizadas entrevistas abertas com executivos da Associação Brasileira de Franchising (ABF) no sentido de captar impressões destes atores quanto às perspectivas do setor, práticas das redes, qualidade da informação contida nos Guias da $A B F$, etc.

Com o mesmo objetivo, foram realizadas ainda duas entrevistas abertas (não estruturadas) com o Gerente de Franquias de uma grande multinacional do ramo de fast-food e com executivos de uma gestora multinacional de shopping centers operando no Brasil. O objetivo foi esclarecer eventuais aspectos cotidianos da operação de redes e unidades franqueadas, não previstos ou ignorados pelas teorias subjacentes.

Foram obtidas junto à ABF informações sobre as redes estrangeiras que operam no Brasil, além de dados históricos quanto à chancela do Selo de Excelência da $A B F$. Esta certificação é oferecida pela $A B F$ às redes participantes de pesquisa de satisfação de franqueados. São medidos nesta pesquisa itens relacionados à forma como franqueadores interagem com a rede de franqueados, qualidade de suporte, valorização da marca, etc.

\subsection{Dimensões e Variáveis}

Como mencionado na Seção 4.6, o modelo de análise quanto aos determinantes do crescimento das redes de franquia no Brasil possui duas fases distintas. Na primeira delas ocorre a identificação dos grupos de comportamento estratégico. Já a segunda consiste do modelo econométrico para explicação do crescimento das redes da amostra.

A primeira fase envolve a identificação de grupos de redes com comportamentos estratégicos similares entre si. Para isso, parte-se de uma estrutura já aplicada em trabalhos anteriores (ver Seção 4.6) para identificação de grupos estratégicos nos setor de franquias. Esta fase é constituída primordialmente de uma análise fatorial na qual se identificam as estruturas que representam os grupos.

A segunda fase consiste de análise econométricas e é composta por dois estágios. No primeiro deles, através de regressão multinomial logística (mlogit), 
variáveis relacionadas ao (i) risco da operação, (ii) suporte ao franqueado e (iii) atratividade da rede modelo de operação das redes são confrontadas aos grupos estratégicos identificados na primeira fase. Esta etapa atende a duas necessidades do estudo: (1) verificar se os atributos operacionais da rede (e das transações) conseguem explicar os grupos e (2) mensurar a probabilidade de que uma rede pertença a um grupo, possibilitando com isso quantificar a razão inversa de Mills. Este segundo item é necessário para controlar para problemas de endogeneidade e viés de seleção conforme descrito nas Seções 4.8 e 4.9 .

Por fim, no segundo estágio, modelos de regressão MQO (Mínimos Quadrados Ordinários) são aplicados sobre as variáveis relacionadas ao modelo de operação das redes, variáveis de ciclo de vida e variáveis de controle.

A variável dependente que orienta a análise é o crescimento das redes. Embora esta variável somente seja trabalhada de forma efetiva nas análises de regressão MQO na parte final do trabalho, ela será ponto de referência na comparação entre os grupos de redes identificados desde a análise fatorial já na próxima seção. Assim sendo, torna-se pertinente identificar a forma como a variável Crescimento foi operacionalizada.

Para todas as redes da amostra foram tabulados dados do total de unidades próprias e franqueadas ano a ano entre os anos de 2009, 2010 e 2011. A partir disso, procedeu-se com o cálculo da média geométrica para apuração da taxa média de crescimento:

$$
\mu=P_{\text {Período }} \sqrt{\frac{\text { Total de Unidades }}{2011}}
$$

A opção pelo período coberto deveu-se a dois motivos primordiais. O primeiro e mais importante é a maximização do tamanho da amostra. Uma amostra (muito) menor do que a atual compromete a metodologia econométrica de análise dos grupos. O segundo motivo relaciona-se com o período de crescimento da economia brasileira após a crise financeira mundial de 2008. 
As variáveis independentes são segregadas em dois conjuntos. O primeiro é empregado na segregação dos grupos estratégicos através da análise fatorial. A estrutura empregada segue a metodologia de Carney e Gedajlovic (1991) e Cataluña et al. (2007), os quais empregam atributos observáveis das redes para identificar grupos de comportamento entre as mesmas.

O segundo conjunto de variáveis atende a metodologia adotada para medir a associação entre os grupos estratégicos e crescimento das redes. Tal metodologia se fundamenta em Hamilton e Nickerson (2003), os quais propõe uma estrutura para mensuração de desempenho considerando problemas de endogeneidade e viés de amostra.

\subsubsection{Identificação dos Grupos}

Sete dimensões são captadas através de 13 variáveis nesta fase. Esta estrutura, embora bastante similar a Carney e Gedajlovic (1991), apresenta algumas diferenças em relação àquele trabalho. Primeiramente, uma das variáveis empregadas por aqueles autores - tempo de integração vertical - é retirada da análise em questão. Uma vez que a idade da rede e o tempo de franquia já fazem parte da análise, e que o tempo de franquia somado ao tempo em que a rede operou apenas com lojas próprias iguala a idade, existirão problemas na segregação dos grupos. Alguns pacotes estatísticos sequer efetuam a análise com variáveis operacionalizadas dessa forma.

A segunda diferença é a inserção de uma dimensão não tratada por aqueles autores: o padrão de ocupação das redes. As seções seguintes detalham as dimensões e as variáveis que as compõem.

\subsubsection{Ciclo de Vida}

Questões relativas ao efeito ciclo de vida precisam ser consideradas no entendimento de grupos de comportamento na indústria (PORTER, 1986, p. 135). A exaustão e/ou saturação de mercados faz parte do ciclo de vida de qualquer produto ou, em alguns casos, modelos de negócio. 
A Idade e o Tempo de Franquia das redes são variáveis cuja influência tem sido mensurada em modelos de ambas as vertentes teóricas tratadas nesta pesquisa. Na TRE, o trabalho pioneiro de Oxenfeldt e Kelly (1969) propôs que as redes fariam menos uso de franquias, na medida em que amadurecessem e desenvolvessem internamente os recursos necessários para operação da rede. A alegada relação negativa entre idade e proporção franqueada, tão recorrente em trabalhos baseados em recursos escassos, não tem recebido suporte empírico em estudos de franquia (COMBS; KETCHEN, 2003).

Pesquisas em TA normalmente utilizam a idade como variável de controle para aspectos como sinalização de reputação e menor risco potencial para franqueados (SHANE, 1998, 2001; SHANE et al., 2006; MICHAEL, 2000b).

A experiência da rede com o arranjo franchising é tratado como indicativo de uma maior capacitação da rede em lidar com problemas de agência, além de aproximar a acumulação de capital reputacional (AZOULAY; SHANE, 2001) ${ }^{25}$. O primeiro aspecto condiciona a rede a lidar com problemas de agência como o freeriding de franqueados. O segundo alivia a rede de incorrer em certos sacrifícios no processo de atração de novos franqueados (taxas de franquia e royalties).

Ainda em TA, Lafontaine e Shaw (2005) verificam que o mix contratual se estabiliza na medida em que as redes tornam-se maduras (acima de 8 anos). Jindal (2011) usa o tempo de franquia como controle para o nível de conhecimento do negócio desenvolvido durante a fase em que a rede operava de forma totalmente integrada. Este conhecimento confere vantagens às redes no momento de selecionar e treinar franqueados, por exemplo, além de capacitar a rede em práticas de monitoramento.

São duas as variáveis relacionadas ao ciclo de vida das redes. A primeira delas é a Idade (tempo de existência da firma), enquanto a segunda variável é o Tempo de Franquia.

Duas medidas são inseridas para caracterizar os grupos de forma a captar a evolução histórica do porte, como em Carney e Gedajlovic (1991). A Expansão

\footnotetext{
${ }^{25}$ Muito embora Kalnins e Mayer (2004) não tenham encontrado relação entre taxa de sobrevivência das unidades da rede e a experiência do franqueador.
} 
Média refere-se à taxa média anual do número de unidades da rede ${ }^{26}$ (porte dividido pela idade).

Além disso, para dissociar unidades totais de unidades franqueadas, inclui-se também taxa média anual de abertura de lojas franqueadas (Novas Franquias). Esta segunda medida considera o número médio de unidades franqueadas abertas pela rede desde a adoção do sistema de franquias pela firma.

\subsubsection{Nível de Dispersão}

Para a teoria da agência, a dispersão espacial das lojas da rede eleva os custos de assegurar esforço do operador local uma vez que o custo de monitoramento é uma função da distância entre os monitores e agentes (BRICKLEY; DARK, 1987, SHANE, 1998). Assim, quando a dispersão geográfica aumenta os custos de monitoramento, o sistema de franchising torna-se uma solução alternativa.

Para a TRE a dispersão não é um determinante para a adoção do modelo de franquias, mas um resultado natural da expansão da rede, o que decorre do alívio das restrições em seus primeiros anos de operação. Ou seja, enquanto os modelos de agency tratam a dispersão como variável explicativa, para TRE trata-se de variável explicada nos modelos de análise.

O nível de Dispersão é operacionalizado somando-se a distância entre a cidade sede de cada rede da amostra e cada cidade brasileira onde a rede tenha operações.

\subsubsection{Porte da Rede}

Para a TRE, na medida em que a rede se aproxima da escala mínima eficiente, torna-se menor a dependência dos recursos providos por franqueados. Além disso, incrementos no porte da firma reduzem o risco presumido por investidores, reduzindo o custo de captação de recursos no mercado (NORTON, 1995; COMBS; KETCHEN, 1999). Diante disso, eleva-se o custo de oportunidade do

\footnotetext{
${ }^{26}$ Cabe frisar que a taxa média de expansão não deve ser confundida com a variável dependente final. Enquanto a taxa média de crescimento é uma média aritmética simples considerando toda a idade da rede, a variável crescimento considera a média geométrica do período 2009-2011, como será detalhado mais adiante.
} 
uso de contratos de franquia em lugar de gerentes com vínculo empregatício. Como resultado, incrementos no porte da rede estariam associados a um menor uso do modelo de franquias.

De forma antagônica, na perspectiva da TA, a elevação do porte da rede implica aumentos no nível de complexidade no gerenciamento e monitoramento das unidades, aumentando a necessidade de investir em mecanismos de incentivos $(\mathrm{ROH}, 2002)$. Isso implicaria em uma relação positiva entre o aumento do porte da rede e a proporção franqueada de lojas.

Para interpretar o papel do porte das redes na dinâmica de expansão das redes, esta medida é aproximada pelo número total de unidades, considerando tanto unidades próprias como franqueadas (Total de Unidades).

A relação entre porte e ciclo de vida também é considerada. A TRE indica que o ganho em porte é positivamente relacionado à proporção de unidades franqueadas, uma vez que esta medida é geralmente mais distintiva em redes jovens, pequenas e buscando alcançar economias de escala (GILLIS; CASTROGIOVANNI, 2010). Ou seja, assim como ocorre com medidas de dispersão, o crescimento é visto como meta da rede para consolidação de porte e faturamento.

Para a TA, porte e dispersão potencializam custos de agência, demandando um balanceamento entre monitoramento e incentivos de forma a garantir desempenho e mitigar comportamentos oportunistas como o problema de free-riding (PIZANTI; LERNER, 2003).

\subsubsection{Estratégia de Preços - Taxas de Franquia}

Pesquisas anteriores sugerem que o aumento no porte das redes depende, entre outras coisas, da capacidade das mesmas em atrair parceiros através de diversas decisões estratégicas, tais como política de preços e alocação de propriedade (SHANE et al., 2006).

A atração de franqueados na TRE significa acessar novas fontes de recursos. Para a TA, questões relativas à atração de franqueados são, sobretudo, de ordem qualitativa no sentido de atrair os melhores parceiros. Ou seja, existe a necessidade 
de sinalizar atratividade do negócio da rede com intuito de atrair franqueados potenciais de qualidade.

Assim, a relação esperada pela visão de recursos escassos é mais custos mais baixos para franqueados relacionados um ritmo de crescimento mais acentuado. Nesta perspectiva, durante a fase de crescimento, os valores de taxas fixas e royalties, por exemplo, tenderiam a ser mais baixos de forma a atrair mais franqueados potenciais.

Para TA haveria certo balanceamento entre taxas fixas e variáveis para ajustes de incentivos ao desempenho ex post, com a taxa fixa atuando como um tipo de hostage (refém), ou seja, um sacrifício financeiro recuperável apenas se a loja obtiver sucesso (DNES, 2003). Royalties seriam utilizados para complementar a taxa fixa inicial em um esforço para lidar com a complexidade de diferentes atitudes por parte dos franqueados quanto ao risco (HUANG, 1997).

$\mathrm{Na}$ operacionalização destas variáveis, considerou-se a taxa fixa inicial cobrada pelas redes (Taxa Fixa de Franquia) e o investimento inicial necessário para instalação da loja (Instalação) em milhares de reais.

Da perspectiva do franqueador, o desembolso de capital para instalação de uma unidade apresenta uma margem de manobra menor. Ou seja, parte destas despesas tem a ver com a aquisição ou aluguel/luvas do imóvel, maquinário, mobília, dentre outros. O preço de muitos destes itens não são diretamente determinados pela rede (alvarás, luvas em shopping centers, preços de maquinários, etc.), ainda que medidas de suporte como o financiamento de franqueados sejam comuns.

Por fim, foram consideradas as taxas percentuais de royalties e publicidade (Royalties). Uma vez que não é possível (pelo menos neste estudo) garantir o pressuposto de que todos os recursos captados pretensamente para publicidade seja convertidos exclusivamente para este fim, optou-se por somar as duas taxas de forma que entrem no modelo como uma única variável. Além disso, houve necessidade de um procedimento de transformação dos dados para aquelas redes que praticam royalties fixos. Procedeu-se a divisão simples do valor informado pelo faturamento médio previsto pelas redes para suas lojas. 


\subsubsection{Provisões Contratuais}

Em contratos de franquia, poucas provisões são mais importantes do que a duração do contrato. Estudos anteriores em TA têm verificado uma relação positiva entre o nível de investimento feito pelo franqueado e a duração do contrato de franquia. Redes maiores e mais maduras tendem a oferecer contratos mais longos com objetivo de aumentar o nível de comprometimento de franqueados com o desempenho da(s) unidade(s) (BRICKLEY et al., 2006; CHAUDEY; FADAIRO, 2008).

A teoria econômica sugere um trade-off entre os contratos de franquia de longo e curto prazo. Contratos de longo prazo ajudam a proteger o franqueado contra o oportunismo franqueador e lhe dá mais tempo para recuperar seu investimento. No entanto, assumindo que é suficientemente caro renegociar antes da data de expiração, contratos de longo prazo tendem reduzir a flexibilidade do franqueador para responder a alterações ambientais. Por exemplo, contratos de longo prazo podem restringir o franqueador de fazer alterações no montante ideal de publicidade, fluxo de abastecimento e as restrições territoriais.

Provisões como a duração de contratos de franquia têm sido objetos de estudo da literatura voltada para o caráter contratual da firma, tais como a teoria dos direitos de propriedade (ARRUÑADA et al., 2001; 2005; 2009), abordagem institucional (BRICKLEY et al., 2006) e Teoria da Agência, Economia dos Custos de Transação (VASQUEZ, 2007, SÁNCHEZ-GÓMEZ et al., 2008). No entanto, este item não é tratado com interesse por trabalhos ambientados da TRE. Assim, a influência desta medida no modelo aqui desenvolvido denota o impacto nas relações de agência captadas.

Em suma, a disposição desta provisão contratual decorre do processo de atração de franqueados previsto pela TA, uma vez que tem por ter relação com a preservação de quase rendas decorrentes do investimento do franqueado em ativos específicos da relação de franquia. A mensuração dessa variável é direta: o tempo de contrato especificado em meses pelas redes de franquia da amostra (Prazo). 


\subsubsection{Mix Contratual}

Estudos de diferentes vertentes teóricas abordam as chamadas formas plurais em arranjos de franquia, ou seja, a coexistência de lojas próprias e franqueadas (também chamada de mix contratual). Por exemplo, Bradach e Eccles (1989) pioneiramente questionam a dependência quase exclusiva do argumento da teoria da agência (à época) em relação à dispersão geográfica e cultural entre unidades. Fosse essa a explicação, então, em localidades distantes da sede das redes todas as unidades seriam franqueadas, o que não ocorre de facto. Os autores propõem a existência de uma simbiose entre lojas próprias e franqueadas, a qual é, em alguma medida, benéfica para cada rede.

Franqueadores conseguiriam mais facilmente avaliar e controlar informações quanto ao comportamento de franqueados através da referência fornecida pela propriedade e operação de algumas de suas unidades (KIDWELL; NYGAARD, 2011). As formas plurais fornecem informações quanto ao nível de eficiência e qualidade capazes de mitigar o problema de free-riding.

Pela perspectiva da TRE, a proporção do mix contratual é circunstancial e relacionada ao ciclo de vida da rede. Ou seja, nos anos de crescimento da rede, a proporção franqueada tende a ser mais acentuada, mas cai à medida que a rede cresce em porte. Essa variação do mix contratual oscilaria ainda com o comportamento do mercado de capitais e variáveis macroeconômicas (SHANE; SPELL, 1998; CASTROGIOVANNI et al., 2006)

Ambas as vertentes teóricas consideram ainda a recompra seletiva de unidades estabelecidas em pontos estratégicos e/ou de maior lucratividade relativa dentro da cadeia (WEAVEN; FRAZER, 2007). Ou seja, unidades com maior potencial de geração de valor para rede são adquiridas ou readquiridas pela rede, a qual faz oferta pela recompra da unidade ou simplesmente não renova o contrato de franquia destas unidades.

A operacionalização do mix contratual no presente modelo de análise considera a proporção de lojas franqueadas nas redes de franquia da amostra (Proporção de Lojas Franqueadas). 


\subsubsection{Estratégia de Ocupação}

No trabalho pioneiro de Rubin (1978), a explicação para franchising fundamentada na teoria da agência preconiza que, em virtude das dificuldades de monitoramento, unidades estabelecidas localidades menores e/ou mais distantes seriam franqueadas, com o oposto valendo para unidades localizadas em grandes centros urbanos.

A literatura trata a escolha do ponto como uma forma de custos irrecuperáveis (sunk cost) para as redes, dada a irreversibilidade, importância estratégica e influência sobre a probabilidade de insucesso acarretada por dessa decisão (MARTIN, 1988; KALNINS; MAYER, 2004).

A pesquisa em TA considera a importância da localidade onde se estabelece a loja do ponto de vista do perfil do consumidor. Dependendo da localização, o consumidor poderá apresentar um perfil de compras mais recorrentes, incentivando o agente local a investir esforço na qualidade trabalhada. O oposto é válido para unidades que se relacionam com clientes cuja experiência de consumo tem pouca ou nenhuma recorrência (KAUFMANN; LAFONTAINE, 1994; BRICKLEY, 1999).

Para captar a forma como as redes posicionaram suas lojas ao longo do território brasileiro três variáveis foram definidas. A primeira (Mercados Emergentes) é constituída para captar a trajetória de expansão das redes entre cidades com diferentes perfis socioeconômicos.

O Instituto Brasileiro de Geografia e Estatística (IBGE) divulga em seu relatório do Censo Demográfico 2010 informações relativas à renda familiar dos domicílios brasileiros (informada por indivíduo por domicilio). Este montante representa o poder de consumo médio por morador nas residências. Assim, cidades com mais domicílios com alto poder médio de consumo são mais propensas a demandar serviços característicos de estratos mais elevados da população, ou ter maior recorrência no consumo.

Por convenção adotou-se o corte em 2 salários mínimos por indivíduo representando as classes $\mathrm{A}$ e $\mathrm{B}$. Para cada cidade, foram somados o número de domicílios na faixa de renda familiar acima de 2 salários mínimos, dividindo-se em seguida esse valor pelo total de domicílios em cada município. 
Para cada rede, apurou-se a proporção média entre os municípios ocupados pelas diversas unidades. A Tabela 4 compara a proporção percentual representativa das classes $A$ e $B$ entre os municípios do Brasil (por região) e aqueles onde se encontram unidades das redes da amostra.

Apesar da nítida (e esperada) presença das redes em municípios de maior potencial médio de consumo em todas as regiões, o nível de concentração é maior na região Nordeste: as redes estão presentes em apenas 13,88\% dos municípios, sendo estes mais $107,69 \%$ mais ricos que a média da região. Em contraste, no Sudeste, as redes estão em quase $40 \%$ dos municípios, sendo estes em um pouco mais de $40 \%$ mais ricos que a média da região.

Tabela 4 - Proporção das classes socioeconômicas A e B por municípios ocupados por redes da amostra

\begin{tabular}{|c|c|c|c|c|c|c|}
\hline \multirow{2}{*}{ Região } & \multicolumn{2}{|c|}{$\begin{array}{c}\text { Total de } \\
\text { Municípios Brasileiros }\end{array}$} & \multicolumn{2}{|c|}{$\begin{array}{l}\text { Municípios Ocupados } \\
\text { pelas Redes da Amostra }\end{array}$} & \multicolumn{2}{|c|}{$\begin{array}{c}\text { Representatividade } \\
\text { da Amostra }\end{array}$} \\
\hline & $\mathbf{N}$ & $\begin{array}{c}\text { Classes } \\
\text { A/B }^{*}\end{array}$ & $\mathbf{N}$ & $\begin{array}{c}\text { Classes } \\
\text { A/B }^{*}\end{array}$ & Ocupação** & $\begin{array}{c}\Delta \text { Classes } \\
{\mathrm{A} / \mathrm{B}^{* * *}}^{* *}\end{array}$ \\
\hline Centro-Oeste & 605 & $10,23 \%$ & 143 & $14,72 \%$ & $23,64 \%$ & $43,89 \%$ \\
\hline Norte & 310 & $5,94 \%$ & 56 & $9,89 \%$ & $18,06 \%$ & $66,50 \%$ \\
\hline Nordeste & 1.794 & $3,25 \%$ & 249 & $6,75 \%$ & $13,88 \%$ & $107,69 \%$ \\
\hline Sul & 1.188 & $14,64 \%$ & 322 & $18,88 \%$ & $27,10 \%$ & $28,96 \%$ \\
\hline Sudeste & 1.668 & $11,71 \%$ & 627 & $16,48 \%$ & $37,59 \%$ & $40,73 \%$ \\
\hline TOTAL & 5.565 & $9,13 \%$ & 1397 & $14,86 \%$ & $25,10 \%$ & $62,76 \%$ \\
\hline \multicolumn{7}{|c|}{$\begin{array}{l}\text { * Proporção média de domicílios de classe A e B dos municípios ocupados por redes da amostra, por região. } \\
\text { O domicílio é considerado na classe A ou B se possui renda per capita igual ou superior a dois salários } \\
\text { mínimos. } \\
\text { ** Proporção dos municípios brasileiros ocupados pelas redes da amostra. } \\
\text { *** Variação percentual entre a proporção das Classes A e B nos municípios brasileiros (por região) e } \\
\text { naqueles ocupados pelas redes da amostra. }\end{array}$} \\
\hline
\end{tabular}

Com base na proporção das classes A e B nas cidades ocupadas pelas redes foi estabelecida uma medida para aproximar a ocupação de mercados emergentes pelas redes da amostra. Para esta pesquisa, o termo "mercados emergentes" é definido como mercados de potencial crescimento, normalmente dispostos em cidades de menor população e/ou renda, mas que constituem oportunidades estratégicas para estas redes.

O procedimento está descrito a seguir. Para cada rede da amostra, foram dispostos os municípios onde as redes mantém operação (dados coletados nos sites das redes entre junho e julho de 2011). As cidades foram ordenadas de forma decrescente pela proporção percentual das classes A e B (somadas) sobre a 
população. Ou seja, se a rede está presente na cidade de São Paulo (proporção das classes A e B em torno de 18\%) e no Rio de Janeiro (proporção das classes A e B em $19 \%$ ), o Rio de Janeiro é tabulado na planilha antes da cidade de São Paulo.

Esta proporção foi multiplicada pelo número de unidades da rede em cada cidade. Ou seja, gerou-se um peso da proporção das classes A e B sobre o total de unidades da rede. Redes com mais unidades em cidades de maior presença das classes A e B (exemplo: São Paulo, Campinas, Curitiba) possuirão valores maiores. A Tabela 5 ilustra o procedimento para uma das redes da amostra.

Tabela 5 - Exemplo da Operacionalização da Variável "Mercados Emergentes" - Distribuição das lojas nas cidades (fonte: elaborado pelo autor)

\begin{tabular}{l|c|c|c}
\hline $\begin{array}{c}\text { Cidade Ocupada } \\
\text { pela Rede }\end{array}$ & $\begin{array}{c}\text { Classes A e B } \\
\text { na cidade (a) }\end{array}$ & $\begin{array}{c}\mathbf{N}^{*} \text { de Lojas } \\
\text { na cidade (b) }\end{array}$ & (a) $\mathbf{x}$ (b) \\
\hline Vitória & 0,35 & 1 & 0,35 \\
Curitiba & 0,35 & 1 & 0,35 \\
Campinas & 0,32 & 1 & 0,32 \\
Ribeirão Preto & 0,32 & 1 & 0,32 \\
Brasília & 0,28 & 5 & 1,41 \\
São Paulo & 0,28 & 1 & 7,49 \\
Bauru & 0,29 & 1 & 0,29 \\
Uberlândia & 0,25 & 1 & 0,25 \\
Salvador & 0,19 & 2 & 0,19 \\
São Luís & 0,17 & 2 & 0,33 \\
Guarujá & 0,18 & $\mathbf{4 3}$ & 0,36 \\
\hline \multicolumn{2}{c}{ TOTAL } & \multicolumn{3}{l}{} \\
\hline * Taxa percentual na população
\end{tabular}

Para cada rede, partindo da cidade com maior para menor proporção de classes A e B em sua população (na vertical descendente), foi-se acumulando a proporção de lojas, cidade a cidade, em relação ao total de unidades da rede conforme indicado no exemplo da Tabela 6 . A rede do exemplo tem 43 unidades no total. 


\begin{tabular}{|c|c|c|c|}
\hline \multirow{2}{*}{$\begin{array}{l}\text { Cidade Ocupada } \\
\text { pela Rede* }\end{array}$} & \multirow{2}{*}{$\begin{array}{l}\mathrm{N}^{\circ} \text { de Lojas } \\
\text { na Cidade }\end{array}$} & \multicolumn{2}{|c|}{ Proporção (\%) } \\
\hline & & Por Cidade & Acumulada \\
\hline Vitória & 1 & 2,3 & 2,3 \\
\hline Curitiba & 1 & 2,3 & 4,7 \\
\hline Campinas & 1 & 2,3 & 7,0 \\
\hline Ribeirão Preto & 1 & 2,3 & 9,3 \\
\hline Brasília & 5 & 11,6 & 20,9 \\
\hline São Paulo & 27 & 62,8 & 83,7 \\
\hline Bauru & 1 & 2,3 & 86,0 \\
\hline Uberlândia & 1 & 2,3 & 88,4 \\
\hline Salvador & 1 & 2,3 & 90,7 \\
\hline São Luís & 2 & 4,7 & 95,3 \\
\hline Guarujá & 2 & 4,7 & 100,0 \\
\hline TOTAL & 43 & & \\
\hline
\end{tabular}

Verificou-se enfim como cada rede se estabelece de acordo com o perfil socioeconômico das cidades ocupadas. Foi apurada a proporção de lojas da rede, ao longo das cidades, seguindo o ordenamento das cidades "mais ricas" para as "mais pobres".

Seguindo a mesma ordem decrescente das cidades com relação à estratificação social (ou seja, proporção representada pelas Classes A e B) verificouse para cada rede o perfil socioeconômico das cidades ocupadas pelos primeiros $40 \%$ de suas lojas. Em seguida, fez o mesmo considerando os primeiros $45 \%$ de suas lojas. E assim procedeu-se até alcançar 100\% das lojas da rede.

O Quadro 3 indica um exemplo deste procedimento. No caso, observa-se que $80 \%$ das lojas da rede estão instaladas em cidades com, no mínimo, $27,7 \%$ de suas populações situadas nas classes A e B. Esta faixa cai para $24,6 \%$ de classes A e B entre 80 e $85 \%$ das lojas, até alcançar um mínimo de $18 \%$ de classes A e B. Portanto, o processo de expansão contempla posicionar suas unidades em cidades com perfil social de menor renda, seja para ocupar posições com pouca ou nenhuma concorrência, incluindo cidades em franca expansão. 
Quadro 3 - Exemplo da Operacionalização da Variável "Mercados Emergentes" (fonte: elaborado pelo autor)

\begin{tabular}{|c|c|c|c|c|c|c|c|c|c|c|c|c|c|}
\hline \multirow{2}{*}{$\begin{array}{l}\text { Proporção } \\
\text { Classes A/B }\end{array}$} & \multicolumn{13}{|c|}{ Proporção das Lojas } \\
\hline & $40 \%$ & $45 \%$ & $50 \%$ & $55 \%$ & $60 \%$ & $65 \%$ & $70 \%$ & $75 \%$ & $80 \%$ & $85 \%$ & $90 \%$ & $95 \%$ & $100 \%$ \\
\hline $\begin{array}{r}35,3 \% \\
35,2 \% \\
32,3 \% \\
32,4 \% \\
28,1 \% \\
27,7 \% \\
28,9 \% \\
24,6 \% \\
19,3 \% \\
16,7 \% \\
18,0 \%\end{array}$ & $\mathrm{x}$ & $\mathrm{x}$ & $\mathrm{x}$ & $\mathrm{x}$ & $\mathrm{x}$ & $\mathrm{x}$ & $\mathrm{x}$ & $\mathrm{x}$ & $\mathrm{x}$ & $\begin{array}{l}x \\
x\end{array}$ & $\mathrm{x}$ & $\mathrm{x}$ & $\mathrm{x}$ \\
\hline
\end{tabular}

Com base nessa aproximação do processo de expansão em direção a cidades de menor renda, obteve-se com esta operacionalização um contínuo (entre $40 \%$ e $100 \%$ das lojas de cada rede, após ocupar cidades de maior presença de classes A e B). Regrediu-se sobre este contínuo a proporção da população das classes A e B, de forma a obter o coeficiente de inclinação da curva representativa dessa expansão.

Um aspecto importante com relação a esta construção diz respeito ao sinal dos valores assumidos. Como o ordenamento decrescente das cidades em termos de proporção representada pelas classes $\mathrm{A}$ e $\mathrm{B}$, o coeficiente da reta de regressão terá inclinação menor ou igual a zero. Essa informação deve ser considerada ao se analisar o sinal dos coeficientes de correlação empregados nos testes.

Obviamente, não está considerada nesta variável a cronologia e sequência de expansão entre cidades. A rede pode ter iniciado suas operações em cidades menores e mais pobres para, então, alcançar mercados mais pujantes. No entanto, o que se busca captar é a diversificação do investimento da rede em mercados menos consolidados.

Uma segunda variável (Shopping Center) é obtida pela proporção média das lojas das redes localizadas em shopping centers, centros comerciais, faculdades e mesmo estádios de futebol. Esta variável busca captar a vinculação da estratégia de certas redes ao estabelecimento de lojas neste tipo de empreendimento. Uma vez que shopping centers criam demanda forçada através do fluxo de pessoas atraídas por lojas âncoras e demais atrativos (CARTER; VANDELL, 2005), busca-se 
identificar na amostra a influência da relação entre redes de franquia e shopping centers.

\subsubsection{Análise do Crescimento das Redes}

Neste estágio um novo conjunto de variáveis é confrontado aos grupos já formados na $1^{\text {a }}$ fase (identificação dos grupos), de forma a ratificar ou não a associação de cada rede a seu grupo. O Quadro 4 dispõe os construtos e variáveis subjacentes.

Três dimensões são consideradas. A primeira aborda a questão operacional das lojas considerando a presença de ativos específicos e padronização, bem como as características dos mercados ocupados pelas redes. A segunda capta o papel do investimento em reputação feito pelos franqueadores no sentido de sinalizar qualidade do formato de negócios e na gestão da rede como um todo. A terceira dimensão capta o balanceamento de incentivos ao longo do tempo, considerando variações em royalties, taxas fixas e no próprio mix contratual ao longo do tempo. As próximas seções detalham cada uma destas dimensões.

\section{Quadro 4 - Construtos Teóricos - Determinantes do Crescimento (fonte: elaborado pelo autor)}

\begin{tabular}{|c|c|c|}
\hline Construto & Variáveis & Proxy \\
\hline \multirow[t]{4}{*}{ Risco na Operação } & Nível de Automação na Loja & $\begin{array}{ll} & \text { Interação entre: } \\
\text { - } & \text { Presença de processos de } \\
\text { transformação } \\
\text { - } \quad \text { Consumo no interior da loja } \\
\text { - } & \left(\text { Automação }=\frac{\text { capital de instalação }}{\frac{\text { Funcionários }}{\text { Área de Loja }}}\right)\end{array}$ \\
\hline & \multirow{2}{*}{ Densidade de Lojas } & Número total de lojas \\
\hline & & $(\overline{\text { População total das cidades ocupadas }})$ \\
\hline & $\begin{array}{l}\text { Investimento em Suporte ao } \\
\text { Franqueado }\end{array}$ & $\begin{array}{l}\text { Variação do número de suportes oferecidos a } \\
\text { franqueados entre } 2009 \text { e } 2011\end{array}$ \\
\hline \multirow{4}{*}{$\begin{array}{l}\text { Mecanismos de } \\
\text { Incentivos }\end{array}$} & $\begin{array}{l}\text { Variação na Proporção } \\
\text { Franqueada }\end{array}$ & $\begin{array}{l}\text { Variação na proporção de lojas franqueadas } \\
\text { entre } 2009 \text { e } 2011\end{array}$ \\
\hline & Conversão para Franquias & $\begin{array}{l}\text { Conversão de lojas próprias para lojas } \\
\text { franqueadas entre } 2009 \text { e } 2011\end{array}$ \\
\hline & $\begin{array}{l}\text { Variação na Taxa Fixa de } \\
\text { Franquia }\end{array}$ & $\begin{array}{l}\text { Variação na taxa fixa de franquia } \\
\text { entre } 2009 \text { e } 2011\end{array}$ \\
\hline & $\begin{array}{l}\text { Variação na Taxa de } \\
\text { Royalties }\end{array}$ & $\begin{array}{l}\text { Variação nas taxas de royalties e publicidade } \\
\text { (somadas) entre } 2009 \text { e } 2011\end{array}$ \\
\hline
\end{tabular}




\subsubsection{Risco na Operação}

Redes de lojas caracterizadas por atividades mais padronizadas, nas quais a qualidade da gestão local é de mais simples verificação e mensuração, tenderão a apresentar menores custos de monitoramento, influenciando desempenho e crescimento da rede. Portanto, mesmo em redes com alto índice de dispersão entre suas lojas, espera-se que processos mais dotados de sistematização e/ou automação propiciem maior controle e coordenação quando comparados àqueles com processos mais intensos em trabalho.

Ou seja, maiores níveis de automação nos processos das lojas propiciam um maior nível de monitoramento, mesmo à distância. A medida empregada para a dispersão é a mesma usada na análise fatorial para segregação dos grupos, ou seja: o somatório da distância entre a cidade sede da rede e as cidades onde opera, independente de a loja ser própria ou franqueada.

Assim, a primeira variável desta dimensão relaciona-se com o efeito da automação/padronização de processos sobre a expansão das redes. Para captar tal efeito, inicialmente calculou-se a razão entre o número de funcionários e a área da loja, de forma a captar a média intensidade em trabalho em cada rede. Quanto menor este número, maior o nível esperado de padronização e/ou automação na loja.

Em seguida, verifica-se a relação entre o número calculado acima e o investimento necessário para abertura de uma unidade da rede. É calculada a razão do investimento pelo grau de automação/padronização de forma a aproximar o nível de esforço da rede investido em processos menos intensos em trabalho. Tal operacionalização é dada por:

$$
\text { Automação }=\frac{\text { Capital para Instalação da lojas }}{(\text { Número de Funcionáriso } / \text { Área da Loja })}
$$

No entanto, espera-se que especificidade das redes não captadas por esta operacionalização distorçam os resultados sem os controles adequados. Por exemplo, uma rede do setor de instrução (escolas de idiomas, por exemplo) tende a 
apresentar lojas com áreas mais amplas em relação a lojas de vestuário e fast-food posicionadas em shopping centers.

Além disso, enquanto algumas redes, independente do setor de atuação, apresentam lojas que operam com a mera comercialização de bens acabados, enquanto outras apresentam processos de transformação de matérias primas, o que gera diferenças na importância do insumo local do gerente de lojas (funcionário ou franqueado). Ou seja, o insumo local difere com relação à forma que o bem transacionado é manipulado pela loja.

Assim, duas variáveis dicotômicas são estabelecidas. A primeira determina se (i) as redes cujas lojas têm função meramente comercial (lojas de vestuário e calçados, por exemplo) e (ii) redes possuindo unidades que efetuam algum tipo de transformação no produto entregue ao consumidor final (como restaurantes). A segunda indica se o consumo do produto transacionado ocorre no interior da loja, captando assim parte do nível de serviço destas unidades. Por fim, o porte da loja é aproximado pelo faturamento médio e capital de giro, dados informados pelas redes no Guia ABF.

A necessidade destes controles pode ser verificada em Barthélemy (2008), o qual encontra efeitos negativos da interação entre valor de marca, proporção de lojas franqueadas e tipo de serviço desempenhado em unidades de redes de franquia. Em redes especializadas em apenas comercializar produtos acabados é relativamente fácil para o franqueador garantir a qualidade. No entanto, na medida em que se eleva o nível de serviço nas unidades de redes, o custo de monitoramento contra free-riding se eleva, comprometendo parte da lucratividade da operação.

Assim, o valor do efeito da automação é interagido com estas duas variáveis dicotômicas para controlar para diferenças no insumo local do gerente. Para isso, é aplicada uma análise fatorial para extrair uma variável representando esta interação entre as variáveis ${ }^{27}$. A esta variável deu-se o nome de Nível de Automação na Loja.

${ }^{27}$ A AUTOMAÇÃo é assim aproximada pela sumarização de 3 dimensões. A validade da construção lógica foi aceita pelo teste de Bartlett $(0,53)$, comunalidades acima de 0,5 para as três variáveis e Alpha de Cronbach de 0,78 . Utilizou-se o método rotacional VARIMAX. A variância explicada pelo único fator extraído foi de $58,74 \%$. 
Além da operacionalização em si, são inseridos alguns controles para lidar com diferenças idiossincráticas entre setores. Para controlar por setor, partiu-se inicialmente da classificação da ABF. No entanto, para simplificar a análise, os 19 setores delineados pela ABF foram sumarizados em sete. $O$ Quadro 5 indica esta sumarização.

Também são incluídos controles para porte e maturidade devido às diferenças inerentes entre redes quanto à experiência e capacidade de investimento. Ou seja, uma rede pode diferir em capacidade de investimento em tecnologia, dado o acesso que tenha a recursos de capital o que tende a variar com o porte da firma. Assim como na fase da análise fatorial, porte é representado pelo número total de unidades, enquanto a maturidade é aproximada pela idade e pelo tempo de franquia das redes.

Quadro 5 - Sumarização dos setores mencionados na ABF (fonte: elaborado pelo autor)

\begin{tabular}{|l|l|}
\hline \multicolumn{1}{|c|}{ Classificação Original da ABF } & \multicolumn{1}{c|}{ Sumarização } \\
\hline Acessórios Pessoais e Calçados & \\
Alimentação & \\
Bares, Restaurantes e Pizzarias & \\
Bebidas, Cafés, Doces e Salgados & \\
Beleza, Saúde e Produtos Naturais & \\
Comunicação, Informática e Eletrônicos & Alimentação \\
Construção e Imobiliárias & Estética \\
Cosméticos e Perfumaria & Instrução \\
Educação e Treinamento & Serviços para Pessoa Jurídica \\
Entretenimento, Brinquedos e Lazer & Saúde \\
Escolas de Idiomas & Varejo ou Serviços Genéricos \\
Fotografia, Gráficas e Sinalização & Vestuário \\
Hotelaria e Turismo & \\
Limpeza e Conservação & \\
Livrarias e Papelarias & \\
Móveis, Decoração e Presentes & \\
Negócios, Serviços e Conveniência & \\
Serviços Automotivos & \\
Vestuário & \\
\hline
\end{tabular}


A segunda variável também tem a ver com monitoramento. O crescimento também é impactado pela possibilidade de ocorrer o problema de free-riding, o qual é função da capacidade de monitoramento existente e da Orientação Temporal do Gestor (OTG), em geral de curto prazo.

O estudo da Orientação Temporal dos Gestores (OTG) é voltado para o entendimento de escolhas intertemporais no âmbito de decisões gerenciais (AGUIAR, 2011). Ou seja, analisa-se nesta perspectiva a dinâmica entre a tomada de decisão no momento de ocorrência de eventos e os custos e benefícios distribuídos ao longo do tempo. Parte da literatura em OTG se volta para problemas de visão de curto prazo do agente (short-termism), o qual, seja por oportunismo ou "miopia gerencial" (ênfase nos resultados de curto prazo), direciona suas ações para maximização de retorno no curto prazo, muitas vezes de forma desalinhada com as estratégias da organização (MARGINSON; MCAULAY, 2008).

No ímpeto de alcançar resultados de curto prazo, o operador local pode ser tentado a extrair renda através de expropriação do valor da marca, economizando esforço e insumos, porém praticando preços no mesmo nível do restante da rede (Seção 3.4).

A Figura 6 esquematiza o efeito esperado da presença do free-riding sobre o crescimento da rede. Uma maior densidade de lojas eleva o impacto do econômico do free-riding para toda a rede, uma vez que, caso ocorra, o consumidor penalizará a rede porque uma de suas unidades não lhe entregou o produto dotado dos atributos esperados ao preço dado. Assim, existiria uma relação positiva entre a densidade de lojas por habitante e o impacto potencial do problema de free-riding, o qual por sua vez têm efeitos danosos sobre o crescimento da rede.

No entanto, o monitoramento eficiente desincentiva comportamentos oportunistas, levando a rede a investir recursos em monitoramento, desviando para este fim recursos que poderiam ser empregados no crescimento de seu número de lojas. 
Figura 5 - Operacionalização da variável "densidade" (fonte: elaborado pelo autor)

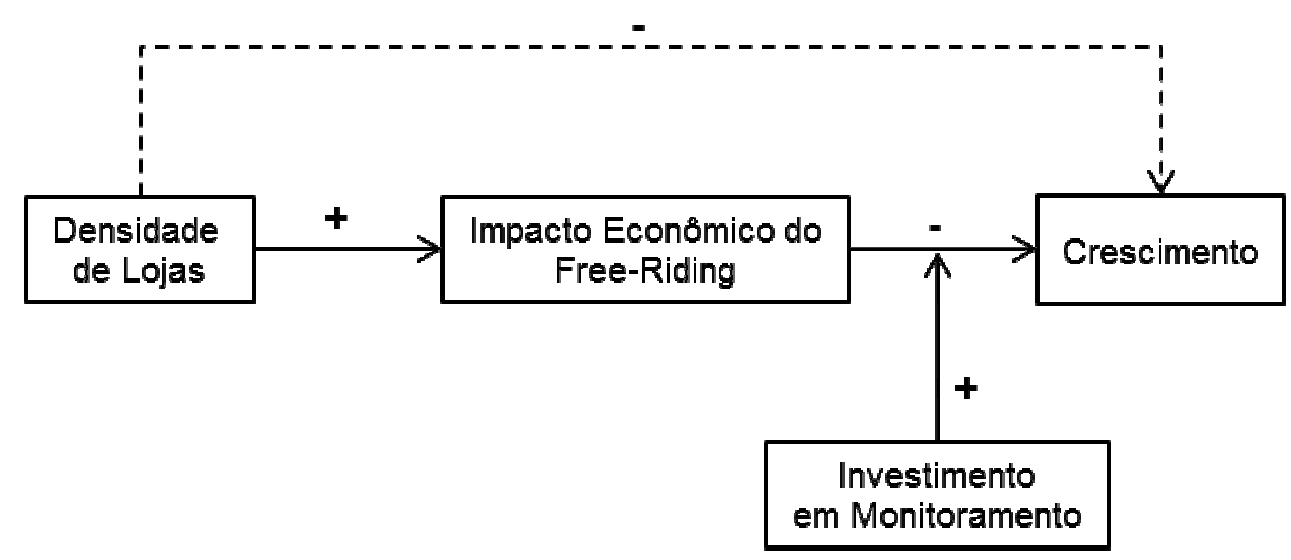

Infelizmente, os dados disponíveis para a pesquisa não permitem mensurar toda a relação descrita no esquema gráfico acima. Assim, a variável Densidade é obtida através da razão entre o total de lojas da rede e o somatório das populações das cidades ocupadas pela mesma. Dessa forma, pôde-se captar apenas seu efeito direto sobre o crescimento no número de lojas da rede (linha tracejada na Figura 7).

Por fim, uma terceira variável - relacionada a controle - é definida de forma próxima à definição clássica de Jensen e Meckling (1976). Ou seja, o controle na organização inclui mais do que apenas de medição ou monitoramento do comportamento do agente. Ele inclui esforços por parte do principal para controlar o comportamento do agente, através de restrições orçamentárias, políticas de compensação, regras operacionais, dentre outros.

Franqueados têm menos poder de barganha quando confrontados com barreiras de saída da relação, o que inclui todo o processo de assimilação do formato de negócios da rede (MICHAEL, 2000b). Por exemplo, toda a carga de treinamento pela que passa o franqueado tende de elevar os custos de mudança para o mesmo. Em outras palavras, eleva-se a especificidade de ativo humana do franqueado, de forma que todo o conjunto de conhecimento e práticas desenvolvidos terá, provavelmente, um menor valor de reuso caso saia precocemente da relação. Tal condicionamento eleva a capacidade do franqueador de manter o comportamento do franqueado dentro dos limites desejados. 
Para captar o investimento em mecanismos de controle das redes usa-se a oferta de suportes administrativos e operacionais a franqueados. Dois fatores indicam a utilidade destes mecanismos: (i) o suporte da rede permite que o insumo do franqueado esteja concentrado sobre a operação da loja de forma que os riscos oscilem apenas em torno da demanda local (NORTON, 1988) e (ii) determinadas formas de apoiar as operações franqueadas assumem uma conotação de controle, uma vez que fomentam a padronização das diversas unidades.

Embora alguns destes suportes sejam de caráter compulsório, determinados pela Lei $n^{\circ} 8.955 / 94$, como o treinamento de funcionários da loja franqueada, outros são facultativos (apoio jurídico, por exemplo). A oferta destes apoios caracteriza um incremento a mais na atratividade da rede por tornar a operação da loja franqueada menos complexa.

Simultaneamente, ao receber suportes às suas operações, os franqueados deixam de participar da tomada de decisão sobre os aspectos cobertos pelos suportes. Assume-se que este quadro indica uma maior discricionariedade por parte da rede para com a loja franqueada. Ou seja, os suportes, em certa medida, configuram um mecanismo de controle das redes. Se o franqueador é responsável pelo projeto arquitetônico da loja franqueada, por exemplo, ele assegura que esta unidade manterá os padrões da rede no tocante a este aspecto. Este é um caso típico do poder discricionário do franqueador sobre suas lojas licenciadas.

Assim, a presença de suportes a franqueados configura uma situação interessante para ambos os lados da relação. Por conhecer o ambiente de negócios envolvendo seus produtos, a rede usa sua experiência para prover franqueados com uma estrutura que facilita a operação da loja em seu estágio inicial e em rotinas durante a operação da loja. Tal estrutura (baseada nos suportes), tanto transmite padronização ao franqueado quanto potencialmente provê a rede com informação atualizada sobre o desempenho da loja, o que contribui para mitigar o problema de risco moral.

Uma vez que a oferta de suportes a franqueados é vista aqui como uma iniciativa que visa atrair franqueados, ao mesmo tempo em que transmite aos mesmos procedimentos técnicos, administrativos e operacionais das redes desejase verificar a efetividade dessa ação. 
Também neste caso, operacionalizou-se a variável "Suporte ao Franqueado" considerando o período entre 2009 e 2011. Assumindo peso igual entre cada um dos 13 tipos de suporte oferecidos e constantes no Guia $A B F^{28}$, foram tabulados os somatórios dos suportes oferecidos ano a ano (ou seja, um valor entre 0 e 13). Em seguida, calculou-se o coeficiente da curva de tendência da oferta destes suportes ao longo do tempo.

Figura 6 - Exemplo da operacionalização da variável "Suporte ao Franqueado" (fonte: elaborado pelo autor)

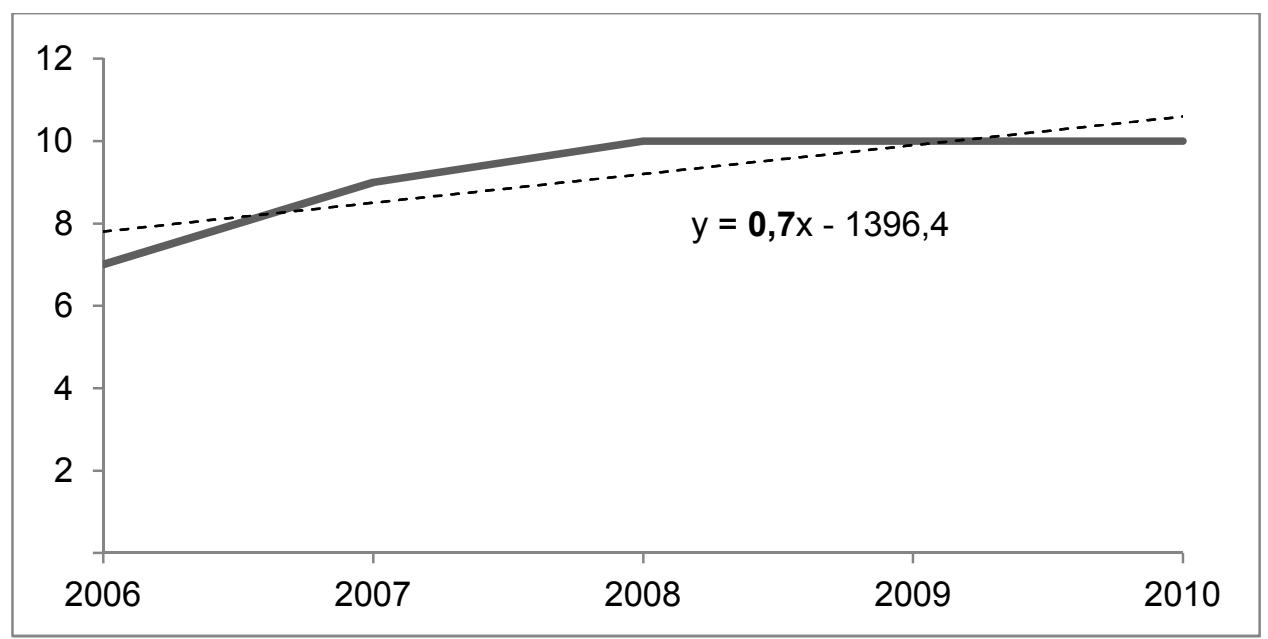

A Figura 7 ilustra o método para uma rede da amostra. A rede do exemplo oferecia 7 tipos de suporte em 2006, passou a ofertar 9 em 2007 e oferece 10 tipos desde 2008. A curva de tendência representativa desta ação da rede apresenta coeficiente angular de aproximadamente 0,7 , o qual será empregado na análise fatorial para distinção dos grupos estratégicos ${ }^{29}$.

${ }^{28}$ A ABF informa através de seus anuários um total de treze tipos de apoio que os franqueadores associados chegam a oferecer a franqueados. Dentre estes estão aqueles cuja Lei $n^{\circ}$ 8955/94 de franquias determina serem obrigação do franqueador, devendo constar na circular de franquia, são eles: orientação sobre método de trabalho $(\mathrm{OM})$, treinamento de funcionários do franqueado (TR), seleção de ponto para instalação da loja (SP) e projeto arquitetônico (PA).

Os demais apoios, de caráter facultativo são: apoio jurídico (AJ), escolha de instalações e equipamentos $(\mathrm{EI})$, apoio (nem sempre gratuito) para alavancagem de financiamento ( $\mathrm{FI}$ ), material promocional (MP), projeto financeiro da unidade (PF), projeto mercadológico (PM), projeto organizacional da unidade (PN), projeto da operação/produção da nova unidade (PO) e propaganda e publicidade (PP). (ABF, 2006).

${ }^{29}$ Neste caso não se aplicou a média geométrica porque grande parte das redes partia de nenhum suporte para um número determinado de suporte, de forma que a inclinação da curva de regressão parece ser uma proxy mais adequada. 


\subsubsection{Atratividade e Modalidade de Incentivos}

Para verificar como as redes modulam sua atratividade através de estruturas de incentivos, são estabelecidas variáveis captando a dinâmica de quatro variáveis relacionadas a este construto.

A proporção entre lojas próprias e franqueadas é um indicador importante da propensão do franqueador a investir esforços na gestão da rede e da marca, estando relacionado obviamente ao risco moral do franqueador (MARUYAMA; YAMASHITA, 2011). Ou seja, se a proporção de lojas próprias é maior, o risco de subinvestimento de esforços pelo franqueador é menor, visto ter parte de sua riqueza vinculada ao desempenho da rede.

Inicialmente, assumindo contratos de franquia como mecanismos de incentivos verticais a agentes locais (COMBS; KETCHEN, 2003), considera-se a variação da proporção franqueada entre 2009 e 2011, calculando-se a variação percentual média através da média geométrica da proporção de lojas franqueadas durante o período.

Assim, a variável " $\Delta \_$Mix Contratual" é operacionalizada pela média geométrica da variação da proporção de lojas franqueadas entre 2009 e 2011.

Reconhece-se que o mix contratual pode refletir aspectos diferentes da gestão da rede, tais como o alívio as necessidade de capital como previsto pela TRE. Ou seja, a variação no mix pode ter motivações diferentes para redes em diferentes estágios de seu ciclo de vida. No entanto, os controles para porte e maturidade mencionados na Subseção 5.6.2.1 são de utilidade também para este construto.

Além disso, a variação do mix contratual pode refletir apenas o crescimento da rede. Por exemplo, se uma rede de unidade verticalmente integrada (ou seja, só existem lojas próprias) passa a adotar o modelo de franquias com intuito de se expandir, a proporção de lojas franqueadas aumentará ao longo do tempo, na medida em que novos franqueados forem atraídos para a rede.

Assim, além da variação do mix contratual, insere-se no modelo de análise também a conversão de unidades. Ou seja, considera-se a conversão de lojas próprias em lojas franqueadas e vice-versa. 
Para esta pesquisa, não estão disponíveis dados no nível de unidade que permita identificar se uma determinada loja é própria ou franqueada. No entanto, é possível comparar a variação de lojas totais à variação de lojas franqueadas, identificando se o número de lojas franqueadas aumentou ou diminuiu frente ao número total de lojas.

Tomando como base o número de unidades franqueadas em 2009, foram verificadas Inicialmente aquelas redes cujo número total de lojas não variou entre 2009 e $2011[\Delta$ (porte $)=0]$. Para estas redes, a variável Conversão considerou simplesmente variação no número de lojas franqueadas.

Em seguida, foram verificadas as redes cujo número total de lojas aumentou entre 2009 e $2011[\Delta($ porte $)>0]$. Se mesmo com tal crescimento o número de unidades próprias decresceu, a variável assume esse valor como o número de conversões de lojas próprias para lojas franqueadas.

Por fim, foram verificadas as redes cujo número total de lojas diminuiu entre 2009 e $2011[\Delta($ porte $)<0]$. Se mesmo diminuindo em tamanho do número de lojas a quantidade de unidades próprias aumentou, então, a variável assume o valor da variação do número de lojas próprias entre 2009 e 2011.

Em função dessa operacionalização, numericamente, quanto maior o valor assumido pela variável, mais unidades terão sido convertidas de loja próprias para loja franqueada. Reciprocamente, o contrário é verdade, com a variável assumindo valores negativos.

A variação do mix contratual capta aspectos verticais da estrutura de incentivos. No entanto, a análise também considera os aspectos horizontais destes incentivos. Duas variáveis não inseridas para captar aspectos temporais do ajuste entre incentivos: a variação taxa fixa de franquia e a variação dos royalties sobre o faturamento.

Ambas as variáveis, usadas para constituição dos grupos na fase de identificação dos grupos estratégicos, são empregadas aqui em sua perspectiva dinâmica, considerando a variação percentual média entre 2009 e 2011 através da média geométrica para este período (similar à variação do mix contratual descrito anteriormente). 


\subsubsection{Estatísticas Descritivas}

A Tabela 7 informa a estatística descritiva das variáveis (exceto variáveis de controle). Os Quadros 6 e 7 contêm um resumo e a identificação de todas as variáveis para as duas etapas do estudo.

Existe um aspecto importante com relação às operacionalizações descritas. Algumas variáveis retiradas dos Guias $\mathrm{ABF}$ são disponibilizadas com valores de mínimo e máximo (faixas). Para reduzir o viés de se assumir que a média entre os dados aproximaria a realidade, optou-se por tomar os valores mínimos. Ceteris paribus, considera-se que existe um limite inferior para o porte da loja que está relacionado com as próprias características do negócio. Os dados tratados dessa forma são o valor de instalação, a taxa fixa de franquia, capital de giro, área da loja e o número de funcionários por loja. 
Tabela 7 - Estatísticas Descritivas

\begin{tabular}{|c|c|c|c|c|c|c|}
\hline Conjunto & Dimensão/Construto & Variável & Mínimo & Máximo & Média & $\begin{array}{l}\text { Desvio } \\
\text { Padrão }\end{array}$ \\
\hline \multirow{13}{*}{$\begin{array}{l}\text { Identificação } \\
\text { dos Grupos } \\
\text { Estratégicos }\end{array}$} & \multirow{4}{*}{ Ciclo de Vida } & Idade & 0 & 61 & 9,95 & 7,55 \\
\hline & & Tempo de Franquia** & 3 & 121 & 19,73 & 14,80 \\
\hline & & Expansão Média (p/ano) & 0,05 & 175 & 4,58 & 10,94 \\
\hline & & Novas Franquias (p/ano) & 0 & 175 & 6,72 & 14,29 \\
\hline & Nível de Dispersão & Dispersão & 250,54 & $20.618 .563,19$ & $2.319 .045,89$ & $2.921 .228,53$ \\
\hline & Porte & Total de Unidades ${ }^{* *}$ & 1 & 1.599 & 73,55 & 146,90 \\
\hline & \multirow{3}{*}{ Atratividade } & Instalação & 0,50 & 1.900 & 130,75 & 151,01 \\
\hline & & TXF & 0 & 350 & 34,14 & 28,16 \\
\hline & & Royalties & 0 & 0,55 & 0,09 & 0,08 \\
\hline & Provisões Contratuais & Prazo de Contrato & 5 & 240 & 60,01 & 18,67 \\
\hline & Mix Contratual & Proporção de Lojas Franqueadas & 0 & 1 & 0,78 & 0,26 \\
\hline & \multirow{2}{*}{ Estratégia de Ocupação } & Mercados Emergentes & 0 & 0,42 & 0,19 & 0,10 \\
\hline & & Shopping Center (\%) & 0 & 100 & 40,7 & 39,3 \\
\hline \multirow{9}{*}{$\begin{array}{l}\text { Análise do } \\
\text { Crescimento }\end{array}$} & \multirow{3}{*}{ Risco na Operação } & Nível de Automação da Loja* & 0,00 & 1 & $-1,18$ & 9,39 \\
\hline & & Densidade & 0,02 & 440,53 & 3,84 & 23,17 \\
\hline & & Suporte ao Franqueado & $-1,80$ & 13 & 2,24 & 2,87 \\
\hline & \multirow{4}{*}{ Atratividade e Inventivos } & $\Delta \_$Mix Contratual (\%) & -100 & 200,0 & 9,3 & 28,2 \\
\hline & & Conversão & 37 & -55 & 0,27 & 4,72 \\
\hline & & $\Delta \_T X F(\%)$ & -100 & 123,6 & 6,0 & 24,0 \\
\hline & & $\Delta \_$Royalties (\%) & -100 & 1314,0 & 9,6 & 84,5 \\
\hline & \multirow{2}{*}{ Controles } & Capital de Giro & 1 & 250 & 30,10 & 34,89 \\
\hline & & Faturamento Médio & 5 & 560 & 76,77 & 66,20 \\
\hline $\begin{array}{c}\text { Variável } \\
\text { Dependente }\end{array}$ & Crescimento & Crescimento (\%) & $-93,0$ & 1771,0 & 35,6 & 126,1 \\
\hline
\end{tabular}

* Efeito Automação é resultado da extração de um fator (com o descrito na Subseção 5.6.2.1), o qual é padronizado, o que explica a média 0 com o desvio padrão igual a 1.

** Também são usadas como variável de controle na regressão mlogit ( $1^{\circ}$ estágio da fase de análise do crescimento das redes) 
Quadro 6 - Variáveis empregadas na identificação dos grupos estratégicos (fonte: elaborado pelo autor)

\begin{tabular}{|c|c|c|c|c|}
\hline Conjunto & Sigla & Descrição & Unidade & Operacionalização \\
\hline \multirow{13}{*}{$\begin{array}{l}\text { Identificação } \\
\text { dos Grupos }\end{array}$} & Idade & Idade da rede & Anos & Idade da rede (referência 2011) \\
\hline & Tempo de Franquia & $\begin{array}{l}\text { Período em que vem adotando o } \\
\text { sistema de franquias }\end{array}$ & Anos & $\begin{array}{l}\text { Período em que vem adotando o sistema de franquias } \\
\text { (referência 2011) }\end{array}$ \\
\hline & Expansão Média (p/ano) & Porte ao longo do tempo & $\begin{array}{l}\text { Número de } \\
\text { lojas }\end{array}$ & Razão entre o número atual de unidades e a idade \\
\hline & Novas Franquias (p/ano) & $\begin{array}{l}\text { Proporção franqueada ao longo do } \\
\text { tempo }\end{array}$ & $\begin{array}{l}\text { Número de } \\
\text { franquias }\end{array}$ & $\begin{array}{l}\text { Razão entre o número atual de lojas franqueadas e o tempo de } \\
\text { franquia }\end{array}$ \\
\hline & Dispersão & $\begin{array}{l}\text { Distância entre a sede da rede e as } \\
\text { lojas }\end{array}$ & $\mathrm{km}$ & $\begin{array}{l}\text { Somatório da distância entre a sede da rede e as cidades onde } \\
\text { opera }\end{array}$ \\
\hline & Total de Unidades & $\begin{array}{l}\text { Número total de lojas da rede (próprias } \\
\text { e franqueadas) }\end{array}$ & $\begin{array}{l}\text { Número de } \\
\text { lojas }\end{array}$ & Número total de unidades \\
\hline & Instalação & $\begin{array}{l}\text { Capital necessário para instalar uma } \\
\text { loja }\end{array}$ & $\begin{array}{l}\text { Milhares de } \\
\text { reais }\end{array}$ & Capital necessário para instalar uma loja \\
\hline & TXF & Taxa fixa de franquia & $\begin{array}{l}\text { Milhares de } \\
\text { reais }\end{array}$ & Taxa fixa cobrada pelas redes indicada no Guia ABF 2011 \\
\hline & Royalties & $\begin{array}{l}\text { Soma das taxas de royalties e } \\
\text { publicidade }\end{array}$ & $\begin{array}{l}\text { Percentual s/ } \\
\text { faturamento }\end{array}$ & $\begin{array}{l}\text { Proporção sobre vendas cobradas pelas redes indicada no Guia } \\
\text { ABF } 2011\end{array}$ \\
\hline & Prazo de Contrato & $\begin{array}{l}\text { Duração do prazo de contrato de } \\
\text { franquia }\end{array}$ & Meses & Prazo indicado no Guia ABF 2011 \\
\hline & $\begin{array}{l}\text { Proporção de } \\
\text { Lojas Franqueadas }\end{array}$ & Proporção de lojas franqueadas & $\begin{array}{l}\text { Percentual de } \\
\text { franquias }\end{array}$ & Proporção percentual de lojas franqueadas na rede \\
\hline & Mercados Emergentes & $\begin{array}{l}\text { Ocupação de cidades menores e mais } \\
\text { pobres }\end{array}$ & Índice & $\begin{array}{l}\text { Intensidade de ocupação de cidades menores e mais pobres } \\
\text { pelas redes (2011) }\end{array}$ \\
\hline & Shopping Center & Presença de lojas em shopping centers & $\begin{array}{l}\text { Percentual de } \\
\quad \text { lojas }\end{array}$ & $\begin{array}{l}\text { Proporção de lojas localizadas em centros comerciais e afins } \\
\text { (2011) }\end{array}$ \\
\hline
\end{tabular}


Quadro 7 - Variáveis empregadas na análise dos determinantes do crescimento (fonte: elaborado pelo autor)

\begin{tabular}{|c|c|c|c|c|}
\hline Conjunto & Sigla & Descrição & Unidade & Operacionalização \\
\hline \multirow{16}{*}{$\begin{array}{l}\text { Análise do } \\
\text { Crescimento }\end{array}$} & Crescimento & Crescimento do número de lojas da rede & Percentual & Variação percentual do número de lojas entre 2009 e 2011 \\
\hline & $\begin{array}{l}\text { Nível de Automação na } \\
\text { Loja }\end{array}$ & Nível de Automação na Loja & Fator & $\begin{array}{l}\text { - } \quad \text { Presença de processos de transformação } \\
\text { - } \quad \text { Consumo no interior da loja } \\
\left.\qquad \text { Automação }=\frac{\text { capital de instalação }}{\frac{\text { Funcionários }}{\text { Área de Loja }}}\right)\end{array}$ \\
\hline & Densidade & Disposição de lojas & $\begin{array}{l}N^{0} \text { de lojas } / \mathrm{N}^{\circ} \\
\text { habitantes }\end{array}$ & $\begin{array}{l}\text { Número de lojas por milhão de habitantes nas cidades ocupadas } \\
\text { pelas redes (2011) }\end{array}$ \\
\hline & Suporte ao Franqueado & Oferta de suporte a franqueados & Percentual & $\begin{array}{l}\text { Variação na oferta de tipos diferentes de suporte a franqueados } \\
\text { entre } 2006 \text { e } 2010 .\end{array}$ \\
\hline & $\Delta \_$Mix Contratual & $\begin{array}{l}\text { Variação da proporção de lojas } \\
\text { franqueadas } 2009-2011\end{array}$ & Percentual & $\begin{array}{l}\text { Variação média dada pela média geométrica entre os períodos } \\
\text { de } 2009 \text { e } 2011\end{array}$ \\
\hline & Conversão & $\begin{array}{l}\text { Conversão de lojas } \\
\text { próprias/franqueadas }\end{array}$ & Número de Lojas & $\begin{array}{l}\text { Comparação entre a variação de unidades próprias e } \\
\text { franqueadas à variação do total de unidades }(2009-2011)\end{array}$ \\
\hline & $\Delta \_T X F$ & $\begin{array}{l}\text { Variação da taxa fixa de franquia 2009- } \\
2011\end{array}$ & Percentual & $\begin{array}{l}\text { Variação média dada pela média geométrica entre os períodos } \\
\qquad \text { de } 2009 \text { e } 2011\end{array}$ \\
\hline & $\Delta \_$Royalties & $\begin{array}{l}\text { Variação do percentual de royalties } \\
2009-2011\end{array}$ & Percentual & $\begin{array}{l}\text { Variação média dada pela média geométrica entre os períodos } \\
\text { de } 2009 \text { e } 2011\end{array}$ \\
\hline & Ctrl - Porte & $\begin{array}{l}\text { Controle para diferenças em capacidade } \\
\text { de investimento }\end{array}$ & Número de lojas & Número total de unidades (2011) \\
\hline & Ctrl - Idade & Idade da rede & Anos & Idade da rede (referência 2011) \\
\hline & Ctrl - Tempo Franquia & $\begin{array}{l}\text { Período em que vem adotando o } \\
\text { sistema de franquias }\end{array}$ & Anos & Período em que vem adotando o sistema de franquias (2011) \\
\hline & Ctrl - Setor & Controle para setor da indústria & Variável dicotômica & $\begin{array}{l}\text { Variável dicotômica indicando o setor em que a rede opera } \\
(2011)\end{array}$ \\
\hline & \multirow{2}{*}{$\begin{array}{l}\text { Ctrl - Processo de } \\
\text { Transformação }\end{array}$} & $\begin{array}{l}\text { Controle para processos de } \\
\text { transformação (nível loja) }\end{array}$ & Variável dicotômica & $\begin{array}{l}\text { Variável dicotômica indicando se as lojas apresentam processo } \\
\text { de transformação ou apenas comercializa produtos (2011) }\end{array}$ \\
\hline & & $\begin{array}{l}\text { Controle consumo do produto ofertado } \\
\text { no interior da loja }\end{array}$ & Variável dicotômica & $\begin{array}{l}\text { Variável dicotômica indicando se o produto transacionado é } \\
\text { consumido no local (2011) }\end{array}$ \\
\hline & \multirow{2}{*}{ Ctrl - Porte de Loja } & Faturamento médio por loja & Milhares de reais & Faturamento médio por loja (2011) \\
\hline & & Capital de giro & Milhares de reais & Capital de giro (2011) \\
\hline
\end{tabular}




\section{IDENTIFICAÇÃO DOS GRUPOS ESTRATÉGICOS}

Como previamente mencionado, esta pesquisa se alinha a trabalhos recentes que buscam explicar a dinâmica de redes de franquia alinhando predições teóricas até pouco tempo concorrentes: a Teoria da Agência (TA) e Economia dos Custos de Transação (ECT) buscando contextualizar franquias como resposta a custos de coordenação; e a Teoria dos Recursos Escassos (TRE) propondo o arranjo de franquias como forma de contornar restrições ao crescimento das redes. Tais visões, antes tidas como concorrentes, têm sido aplicadas em conjunto na explicação do fenômeno (CASTROGIOVANNI et al., 2006; COMBS et al., 2011).

Individualmente, cada uma destas perspectivas é estimulada por um conjunto distinto de fatores causais. No início, TA e TRE eram encontradas em um corpo separado de literatura (CARNEY; GEDAJLOVIC, 1991). A pesquisa em marketing e varejo propunha o modelo de franquias como forma de contornar restrições sobre o crescimento da firma. Por outro lado, a literatura econômica enfatizava o papel do equilíbrio entre custos de agência nas relações de franquia.

Mais recentemente estas visões têm sido integradas, na medida em que a dinâmica temporal das redes tem sido mais bem entendida. Por exemplo, Castrogiovanni et al. (2006) identificam um padrão cúbico no comportamento da curva do mix contratual ao longo do tempo, indicando que efeitos da escassez de recursos é mais sentido enquanto a rede é ainda jovem, enquanto problemas de agência passam a exercer maior influência com a maturidade e fortalecimento da marca.

Na presente pesquisa, a orientação da análise das estratégias de expansão de redes de franquia deriva fundamentalmente de dois trabalhos que buscaram comparar a aderência de TA e TRE na explicação da decisão do mix contratual. No primeiro, Carney e Gedajlovic (1991) compilam 13 variáveis de 7 dimensões estratégicas para identificar uma taxonomia de redes de franquia canadenses quanto ao nível de integração vertical. O Quadro 8 elenca dimensões e variáveis aplicadas neste estudo. 
Quadro 8 - Variáveis em Carney e Gedajlovic (1991)

\begin{tabular}{|l|l|}
\hline \multicolumn{1}{|c|}{ Dimensão } & \multicolumn{1}{c|}{ Variável/Proxy } \\
\hline Porte & Número total de unidades \\
\hline Dispersão & Número de unidades fora da cidade sede \\
\hline \multirow{2}{*}{ Crescimento } & Média de unidades abertas por ano \\
\cline { 2 - 2 } & Média de franquias vendidas por ano \\
\hline \multirow{4}{*}{ Preço } & Taxa de franquia \\
\cline { 2 - 2 } & Capital de instalação da unidade \\
\cline { 2 - 2 } & Royalties sobre faturamento \\
\cline { 2 - 2 } & Taxa de publicidade \\
\hline Provisões Contratuais & Prazo de contrato \\
\hline Integração Vertical & Proporção de lojas franqueadas \\
\hline \multirow{3}{*}{ Experiência } & Idade da rede \\
\cline { 2 - 2 } & Tempo de franquia da rede \\
\cline { 2 - 2 } & Tempo em que a rede operou antes de adotar o sistema de franquias \\
\hline
\end{tabular}

Um segundo trabalho usado como referência aqui é Combs e Ketchen (2003), os quais aplicam meta análise sobre trabalhos anteriores para testar as dez hipóteses mais recorrentemente testadas em estudos voltados para a decisão de franquear (seis derivadas de TA e quatro derivadas da TRE). O Quadro 9 esquematiza as relações testadas na forma de hipóteses, indicando ainda o padrão de relacionamento esperado ${ }^{30}$.

Quadro 9 - Hipóteses e construtos em Combs e Ketchen (2003)

\begin{tabular}{|c|c|l|c|}
\hline Teoria & Hipóteses & \multicolumn{1}{c|}{ Construto } & Relação com Franchising \\
\hline \multirow{4}{*}{ TRE } & $\mathrm{H}_{1}$ & Idade & - \\
\cline { 2 - 4 } & $\mathrm{H}_{2}$ & Porte & - \\
\cline { 2 - 4 } & $\mathrm{H}_{3}$ & Crescimento da Rede & + \\
\cline { 2 - 4 } & $\mathrm{H}_{4}$ & Escassez de Capital & + \\
\hline \multirow{4}{*}{ TA } & $\mathrm{H}_{5}$ & Dispersão Geográfica & + \\
\cline { 2 - 4 } & $\mathrm{H}_{6}$ & Conhecimento do Mercado Local & + \\
\cline { 2 - 4 } & $\mathrm{H}_{7}$ & Insumo do Franqueador & - \\
\cline { 2 - 4 } & $\mathrm{H}_{8}$ & Taxas Fixas & - \\
\cline { 2 - 4 } & $\mathrm{H}_{9}$ & Royalties & + \\
\cline { 2 - 4 } & $\mathrm{H}_{10}$ & Tamanho da Loja & - \\
\hline
\end{tabular}

${ }^{30}$ Os autores somente corroboram as hipóteses 5, 6, 7 e 10 do Quadro 9 (ou seja, nenhuma hipótese da TRE foi suportada). No entanto, os autores sugestionam problemas de validade de construto nas pesquisas analisadas, além da questão temporal em relação à capacidade explicativa da TRE. Ou seja, esta visão é mais aderente nos primeiros dias da rede, quando determinadas restrições a afetam mais severamente. 
No entanto, frisam-se algumas das hipóteses testadas por Combs e Ketchen (2003) não são operacionalizáveis com os dados disponíveis para a presente pesquisa. O Quadro 10 elenca as dimensões e variáveis empregadas na análise fatorial da presente pesquisa para caracterização dos grupos estratégicos.

Ambos os trabalhos estão voltados primariamente para o nível de integração vertical aproximado pelo mix contratual. Ou seja, um maior ou menor uso de franquias pela rede de acordo com predições de TA e TRE. Ainda que a presente pesquisa esteja voltada para o entendimento da dinâmica de expansão das redes, ela busca se beneficiar pela taxonomia de redes e desenvolvimento de construtos propiciados por estes dois trabalhos.

Quadro 10 - Dimensões e variáveis

\begin{tabular}{|l|l|}
\hline \multicolumn{1}{|c|}{ Dimensão } & \multicolumn{1}{c|}{ Variável/Proxy } \\
\hline \multirow{2}{*}{ Ciclo de Vida ${ }^{31}$} & Idade da rede \\
\cline { 2 - 2 } Nível de Dispersão & $\begin{array}{l}\text { Sompo de franquia da rede } \\
\text { brasileiras onde a rede opera }\end{array}$ \\
\hline \multirow{3}{*}{ Porte da Rede } & Número total de unidades \\
\cline { 2 - 2 } & Média anual de unidades abertas \\
\cline { 2 - 2 } & Média anual de abertura de unidades franqueadas \\
\hline \multirow{2}{*}{ Pricing } & Taxa de franquia \\
\cline { 2 - 2 } & Capital de instalação da unidade \\
\cline { 2 - 2 } & Royalties sobre faturamento + Taxa de Publicidade \\
\hline Provisões Contratuais & Prazo de contrato \\
\hline Mix Contratual & Proporção de lojas franqueadas \\
\hline \multirow{2}{*}{ Estratégia de Ocupação } & Proporção de lojas instaladas em shopping centers \\
\cline { 2 - 2 } & $\begin{array}{l}\text { Características das cidades ocupadas pela rede e distribuição } \\
\text { de lojas entre estas cidades. }\end{array}$ \\
\hline
\end{tabular}

Uma oitava dimensão é adicionada àquelas propostas por Carney e Gedajlovic (1991): a estratégia de ocupação. Insere-se assim na análise um aspecto mais qualitativo do processo de expansão. Desde Rubin (1978), a TA preconiza que lojas em áreas distantes e em mercados não tão consolidados tendem a ser alocadas a franqueados. Em função disso, busca-se captar tal construção teórica com esta dimensão dos grupos estratégicos.

\footnotetext{
${ }^{31}$ Como será mencionado adiante, o tempo em que a rede operou antes de adotar o sistema de franquias não será considerado neste trabalho por questões operacionais do modelo estatístico.
} 
Visando identificar padrões de estratégias de expansão das redes de franquia no Brasil, as redes da amostra foram segregadas em grupos discretos por meio de uma Análise Fatorial ${ }^{32}$.

A análise fatorial ajusta um modelo de dados multivariados estimando sua interdependência. Nessa técnica, as variáveis de interesse dependem de um número menor de fatores não observados (latentes). Cada variável é assumida como dependente de uma combinação linear dos fatores comuns e os coeficientes são conhecidos como cargas. Assim, a análise fatorial é útil na identificação de interrelações entre as variáveis que não são diretamente observáveis, segregando uma amostra em segmentos relativamente homogêneos (MARTÍNEZ-TORRES; TORALMARÍN, 2010) ${ }^{33}$. Portanto, é um meio útil de segmentar uma amostra em grupos relativamente homogêneos (CARNEY; GEDAJLOVIC, 1991). Uma rotação ortogonal da matriz fatorial garante fatores representando construtos unidimensionais (o que facilita a vinculação a preceitos teóricos).

No estudo em questão, os fatores extraídos são interpretados como uma representação das estratégias adotadas pelas redes com relação ao processo de expansão. As cargas fatoriais destacam os componentes de cada estratégia, de modo que a composição e validade de construto de cada um são estabelecidas constitutivamente.

Gera-se com isso uma taxonomia de firmas onde cada grupo é formado com base na similaridade entre atributos, os quais decorrem de um processo histórico, conforme mencionado na Seção 3.8. Tais agrupamentos são compostos de organizações relativamente homogêneas em termos de estratégia de expansão de rede. Para isto aplica-se a conceituação de grupos estratégicos discutidos na Seção 3.9 .

Os procedimentos adotados nesta pesquisa se assemelham aos trabalhos de Carney e Gedajlovic (1991), Cataluña et al. (2007) e Martínez-Torres e Toral-Marín

${ }^{32}$ A denominação precisa do método aqui empregado é análise de componentes principais, a qual consiste em decompor os dados originais empregados na análise em busca de uma relação linear. A análise de fatores propriamente dita, por sua vez, consiste em estimar matematicamente os fatores (FIELD, 2009, p. 562). Por questões de simplicidade, neste trabalho emprega-se o termo "análise fatorial" em lugar de "análise de componentes principais".

${ }^{33} \mathrm{O}$ processo de agrupamento (geração de grupos ou clusters) de variáveis conduzido através de análise de agrupamentos convencional é indicado quando o que se pretende é agrupar respostas ao invés de agrupar respondentes (observações). Para este segundo caso, o mais indicado é aplicar a análise fatorial de tipo Q, o que é feito nesta pesquisa (HAIR et al., 2006, p. 97). 
(2010), dentre outros. Estes trabalhos identificam grupos estratégicos entre redes do Canadá, Espanha e dos Estados Unidos, respectivamente. Os grupos encontrados foram interpretados e nominados de acordo com o comportamento estratégico interpretado em cada estudo. No caso de Carney e Gedajlovic (1991) os grupos encontrados foram: (i) redes de rápido crescimento, (ii) redes demandando maiores investimento de franqueados, (iii) redes que adotaram o sistema de franquias após longo tempo de operação integrada, (iv) franqueadores maduros e (v) redes com baixo nível de sucesso.

Como já mencionado, somente foram inseridas na amostra redes informando todos os dados necessários às variáveis operacionalizadas. Da amostra inicial, 376 redes de franquia são utilizadas na análise. As redes tratadas no estudo são de porte variado, desde redes pequenas e jovens até grandes redes multinacionais, cobrindo um espectro diversificado de segmentos de mercado.

Testes Kolmogorov-Smirnov efetuados sobre as variáveis indicam que nenhuma delas apresenta-se normalmente distribuídas a $5 \%$ de significância ( $p<$ 0,05), o que é atenuado pelo tamanho da amostra (376 observações). A Tabela 8 indica as correlações de Pearson entre as variáveis empregadas. Todas as variáveis apresentam algum tipo de correlação significante a $1 \%$ acima de $10 \%$ com pelo menos outras duas variáveis.

Alguns aspectos relativos à amostra parecem sugerir que a TA seria moderadamente sustentada pelos dados ainda consolidados. As dimensões geográficas (como é o caso do Brasil) sugerem altos custos de monitoramento, o que, segundo TA, induziria as redes a adotarem sistemas de incentivos mais poderosos visando melhor desempenho das unidades (WEAVEN; FRAZER, 2007). Ou seja, considerando a elevação em custos de monitoramento na medida em que a rede aumenta sua presença em nível nacional, seria esperado que aumentassem as motivações para que ela invista em mecanismos de incentivo, como no caso a oferta de contratos de franquia ao gerente local.

A proporção de lojas franqueadas apresenta correlação moderada, positiva e significante com a dispersão e com o porte da rede (aproximadamente 20\%).

A presença das redes em mercados emergentes indicaria a necessidade de desenvolvimento de conhecimento desse mercado, o qual é de custosa aquisição 
por parte da rede, o que incentiva parcerias com agentes externos, isto é, franqueados.

Tabela 8 - Matriz de correlações de Pearson para as variáveis empregadas na análise fatorial (fonte: elaborado pelo autor)

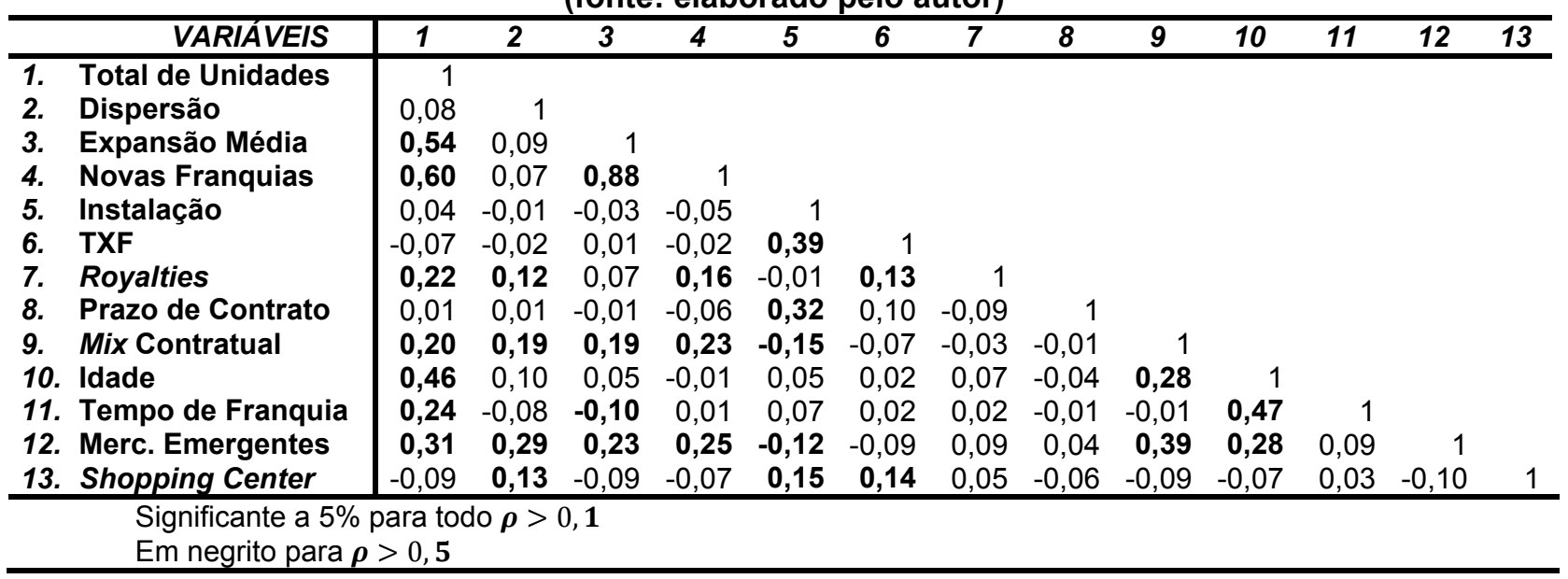

A proporção franqueada apresenta uma grande correlação com a com a diversificação das redes em mercados não tão ricos (com maior presença das classes $C$ e D). Isso pode indicar uma estratégia de alocar a propriedade de mais lojas a franqueados como forma de reduzir riscos de operar em mercados desconhecidos (MICHAEL, 1996). Ainda que a simples saturação de mercados mais maduros possa também ser uma explicação do que incentivaria as redes a buscar mercados alternativos, a necessidade de conhecimento acumulado para operar em tais mercados é condição sine qua non para sobrevivência da unidade.

A análise das correlações também auxilia a identificar uma eventual e indesejada multicolinearidade nos dados. Field (2009, p. 578) indica que o determinante da matriz de correlação deve ser superior $10^{-5}$. Neste caso, o valor do determinante da matriz de correlação é de 0,02 , o que supera bastante o valor mínimo aceitável.

Estudos anteriores em TA indicam o uso da taxa fixa inicial paga por franqueados como um "refém" (hostage) recuperável com o sucesso da unidade (NORTON, 1988, DNES, 2003) ${ }^{34}$. Ou seja, trata-se de um mecanismo de incentivo

34 Trabalhos mais recentes têm evidenciado considerável falta de suporte a esta teoria (COMBS et al., 2004), ou seja, maiores taxas fixas praticadas não estão relacionados com a propensão a franquear (COMBS; KETCHEN, 2003). Trabalhos mais próximos a TRE relacionam altas taxas de royalties a sinalização da qualidade da marca (GALLINI; LUTZ, 1992; GILLIS; CASTROGIOVANNI, 2010). 
para potencializar o desempenho gerando ganhos para a rede na forma de royalties. No entanto, não se observa nenhuma relação significativa entre uma maior proporção de lojas franqueadas e a taxa de franquia, indicando que não é uma prática comum entre todos os segmentos de redes no Brasil.

Também não se observa relação significante entre royalties e a proporção franqueada. Em TA, royalties geram incentivos para franqueadores investirem insumos no sentido de potencializar as vendas entre as unidades da rede, uma vez que se beneficiam diretamente do incremento da receita. Assim, desde que as taxas de royalties não excedam suas margens de lucro, franqueados aceitam o pagamento destas taxas variáveis sobre seu faturamento (SHANE, 1998). A ausência de qualquer relação nos dados agregados indica que qualquer efeito dos royalties - se existente - deveria estar associado a outros fatores, como remuneração do valor da marca, por exemplo.

Devido ao risco associado à expropriação de quase rendas por parte do franqueados, TA prevê uma forte associação negativa entre franchising e necessidades de investimento por parte do franqueado (ARRUÑADA, et al., 2001; 2005; 2009). Os resultados preliminares corroboram limitadamente esta previsão $(\rho=-0,15)$.

Para TA contratos mais longos são oferecidos quando o nível de investimento em ativos específicos gera quase rendas expropriáveis (BRICKLEY et al., 2006; VASQUES, 2007). Uma maior duração do contrato seria usada como salvaguarda para o investimento de franqueados. Não se observa nenhuma relação significante entre prazo e o mix contratual.

\subsection{Resultados da Análise Fatorial}

Os cinco fatores extraídos através da análise de componente principal (Tabela 9) explicam $66,98 \%$ da variância nos dados. O critério para definição do número de fatores extraídos baseia-se na percentagem da variância explicada. Tal critério garante significância prática para os fatores extraídos de forma que, no mínimo, o fator com menor carga explique a variância de uma das variáveis do modelo (HAIR et al., 2006, p. 102). 
Tabela 9 - Análise de componente principal - Total da variância explicada (fonte: elaborado pelo autor)

\begin{tabular}{c|c|c|c|c|c|c}
\hline \multirow{2}{*}{ Componentes } & \multicolumn{3}{|c|}{ Autovalores Iniciais } & \multicolumn{3}{c}{ Autovalores Rotacionados (VARIMAX) } \\
\cline { 2 - 7 } & Total & Variância & $\begin{array}{c}\text { Percentual } \\
\text { Acumulado }\end{array}$ & Total & Variância & $\begin{array}{c}\text { Percentual } \\
\text { Acumulado }\end{array}$ \\
\hline 1 & 3,44 & 26,48 & 26,48 & 2,89 & 22,23 & 22,23 \\
2 & 1,69 & 12,99 & 39,46 & 1,84 & 14,15 & 36,39 \\
3 & 1,60 & 12,33 & 51,79 & 1,53 & 11,76 & 48,15 \\
4 & 1,23 & 9,48 & 61,28 & 1,49 & 11,50 & 59,65 \\
5 & 1,03 & 7,96 & $\mathbf{6 9 , 2 4}$ & 1,25 & 9,59 & 69,24 \\
\cline { 3 - 7 } & 0,93 & 7,14 & 76,38 & & & \\
7 & 0,81 & 6,22 & 82,60 & & & \\
8 & 0,64 & 4,90 & 87,50 & & & \\
9 & 0,56 & 4,32 & 91,83 & & & \\
10 & 0,48 & 3,70 & 95,52 & & & \\
11 & 0,36 & 2,79 & 98,31 & & & \\
12 & 0,14 & 1,08 & 99,39 & & & \\
13 & 0,08 & 0,61 & 100,00 & & & \\
\hline
\end{tabular}

A Tabela 10 indica as comunalidades das variáveis empregadas no modelo. Ou seja, ela indica a proporção da variância comum contida em cada variável. Todas as variáveis apresentam forte correlação com os fatores extraídos $(r>0,4)$, o que justifica a presença de todas no modelo.

Tabela 10 - Comunalidades

(fonte: elaborado pelo autor)

\begin{tabular}{|c|c|c|}
\hline Variáveis & Inicial & Extração \\
\hline Total de Unidades & 1 & 0,86 \\
\hline Dispersão & 1 & 0,76 \\
\hline Expansão Média & 1 & 0,83 \\
\hline Novas Franquias & 1 & 0,86 \\
\hline Instalação & 1 & 0,72 \\
\hline TXF & 1 & 0,63 \\
\hline Royalties & 1 & 0,45 \\
\hline Prazo de Contrato & 1 & 0,67 \\
\hline Mix Contratual & 1 & 0,75 \\
\hline Tempo de Franquia & 1 & 0,77 \\
\hline Idade & 1 & 0,63 \\
\hline Mercados Emergentes & 1 & 0,62 \\
\hline Shopping Center & 1 & 0,45 \\
\hline
\end{tabular}

A matriz da solução fatorial foi ortogonalmente rotacionada pelo método VARIMAX com normalização Kaiser, de forma a facilitar a interpretação das cargas significativas através da independência dos fatores. Ou seja, a ortogonalidade indica que os fatores são não relacionados, facilitando a interpretação pela análise da variância agrupada das variáveis. Por este método, fortalece-se uma tendência de 
que as cargas assumam cargas mais altas (próximas de "1" ou "-1") em alguns fatores, com cargas nulas nos demais (HAIR et al., 2006, p. 106).

As cargas fatoriais representam a correlação entre cada variável com os fatores extraídos (FIELD, 2009, p. 569). Para este tamanho de amostra, recomendase considerar cargas acima de 0,3 (em módulo). Assim, todas as cargas acima desse valor foram consideradas, de forma que algumas variáveis apresentam cargas em mais de um fator (mesmo após a rotação dos fatores). Cargas mais baixas, embora não tão acentuadas, auxiliam na articulação e no refinamento da descrição das estratégias individuais. A Tabela 11 indica a distribuição das cargas relevantes já rotacionadas entre os fatores extraídos.

Os escores fatoriais foram extraídos pelo método Anderson-Rubin, o qual controla para problema de auto correlação (FIELD, 2009, p. 560). A análise do valor e sinal assumidos pelos escores de cada uma das redes da amostra serviu como base para classificação das mesmas entre os grupos. Ou seja, interpreta-se que uma determinada rede está associada a uma estratégia de expansão com base em sua carga mais significativa entre os cinco fatores extraídos.

Tabela 11 - Matriz de Componentes Rotacionados (VARIMAX) (fonte: elaborado pelo autor)

\begin{tabular}{l|c|c|c|c|c}
\hline \multirow{2}{*}{ Variáveis } & \multicolumn{5}{|c}{ Componente (Fatores) } \\
\cline { 2 - 6 } & $\mathbf{1}$ & $\mathbf{2}$ & $\mathbf{3}$ & $\mathbf{4}$ & $\mathbf{5}$ \\
\hline Novas Franquias & 0,90 & & & & \\
Expansão Média & 0,88 & & & & \\
Total de Unidades & 0,78 & 0,48 & & & \\
Dispersão & 0,73 & 0,46 & & 0,32 & \\
Tempo de Franquia & & 0,81 & & & \\
Idade & & 0,79 & & & \\
Instalação & & & 0,80 & & $-0,36$ \\
Prazo de Contrato & & & 0,56 & & 0,56 \\
TXF & & & & 0,86 & \\
Mix Contratual & & & & 0,74 & \\
Mercados Emergentes & & & & & 0,64 \\
Shopping Center & & & & \\
Royalties & & &
\end{tabular}

Para verificar a significância geral do modelo são verificados o teste de esfericidade de Bartlett, a estatística KMO e a Medida de Adequação da Amostra (MSA - Measures of Sampling Adequacy). A estatística de Kaiser-Meyer-Olkin (KMO), cujo valor situa-se entre 0 e 1 , compara as correlações simples com as 
correlações parciais. Um valor próximo de zero pode indicar que a análise fatorial pode não ser adequada, pois existe uma correlação fraca entre as variáveis (FAVERO et al., 2009, p. 241). Se expressa a estatística KMO por:

$$
K M O=\frac{\sum_{i \neq j} \sum r_{i j}^{2}}{\sum_{i \neq j} \sum r_{i j}^{2}+\sum_{i \neq j} \sum a_{i j}}
$$

No presente caso, o resultado para esta estatística foi 0,60, consideravelmente acima do que é recomendado por Kaiser (1974). O teste de esfericidade de Bartlett consiste no teste da hipótese nula de que a matriz de correlações pode ser a própria matriz identidade. Ou seja, o teste deve ser não significante o que de fato ocorre no presente caso.

\subsection{Verificação da Diferenciação entre Grupos}

Antes de especificar a característica e nominação de cada grupo, procedeuse com a confirmação da distinção entre grupos. Para validar a utilidade deste método de categorização, foi aplicada uma análise multivariada da variância (MANOVA) sobre os fatores constituídos (as 9 variáveis empregadas no modelo são aqui tratadas como variáveis dependentes).

A Tabela 12 indica as quatro estatísticas multivariadas para MANOVA. Como indicado, todas apontam para significância do teste. Ou seja, rejeita-se a hipótese nula de que não existe diferença entre os grupos estratégicos. Testes univariados (ANOVA) foram executados para todas as variáveis rejeitando a hipótese nula de que as médias são idênticas entre os grupos $(p<0)$, corroborando a análise multivariada (MANOVA).

Alguns pressupostos da MANOVA foram verificados para fins de garantia quanto à confiabilidade dos resultados. A validade do teste MANOVA exige normalidade multivariada entre as variáveis. Para este estudo, aceitou-se testar a normalidade univariada para cada variável (pré-condição para normalidade 
multivariada). O teste Kolmogorov-Smirnov indicou ausência de normalidade na distribuição das variáveis, mas isso é atenuado pelo tamanho da amostra.

Tabela 12 - Testes Multivariados (MANOVA)

\begin{tabular}{l|l|c|c|c}
\hline \multicolumn{2}{|c|}{ Efeito } & Valor & Estatística F & Significância \\
\hline \multirow{4}{*}{ Grupos } & Traço de Pillai & 1,80 & 22,80 & 0,00 \\
& Lambda de Wilks & 0,09 & 23,50 & 0,00 \\
& Traço de Hotelling & 3,45 & 23,72 & 0,00 \\
& Maior Raiz de Roy & 1,31 & 36,48 & 0,00 \\
\hline \multicolumn{4}{l}{ Significante a 5\% }
\end{tabular}

O teste de Box é usado para verificar a hipótese de que as matrizes de variância e covariância são idênticas entre os grupos. No caso desta análise, o teste foi significativo $(p<0,5)$, o que indica que a hipótese foi violada e que é necessária certa parcimônia na interpretação dos resultados.

O terceiro pressuposto analisado diz respeito à necessidade de igualdade das variâncias dos erros entre os grupos. O teste de Levene é projetado para verificar a hipótese nula de que as variâncias são todas iguais (FIELD, 2009 p. 330). No caso, o teste é não significante para nenhuma das variáveis (Tabela 13). Apesar destas violações dos pressupostos da MANOVA, prossegue-se com o teste, uma vez que o que se quer neste ponto da pesquisa é meramente identificar se e como os grupos diferenciam-se entre si.

Tabela 13 - Teste de Levene (fonte: elaborado pelo autor)

\begin{tabular}{l|c|c}
\hline \multicolumn{1}{c|}{ Variável } & Estatística F & Significância \\
\hline Total de Unidades & 27,48 & 0 \\
Dispersão & 4,39 & 0 \\
Expansão Média & 26,87 & 0 \\
Novas Franquias & 27,68 & 0 \\
Instalação & 21,52 & 0 \\
TXF & 2,56 & 0,04 \\
Royalties & 14,50 & 0 \\
Prazo de Contrato & 67,99 & 0 \\
Mix Contratual & 24,97 & 0 \\
Tempo de Franquia & 7,01 & 0 \\
Idade & 9,45 & 0 \\
Mercados Emergentes & 7,17 & 0 \\
Shopping Center & 3,10 & 0,02 \\
\hline Significante a 5\%
\end{tabular}

Um procedimento post hoc foi adotado para garantir a validade das conclusões de MANOVA, ainda que se reconheça a violação de algumas hipóteses 
necessárias. Dada a condição de tamanhos diferentes dos grupos em termos de número de observações (redes), adotou-se o procedimento de Games-Howell (FIELD, 2009, p. 323).

O Quadro 11 traz o procedimento post hoc de Games-Howell com as diferenças entre grupos para todas as variáveis. Todas as diferenças indicadas são significantes a 10\%. Para facilitar a leitura, ao invés do valor com a média da diferença, indicou-se o sinal de maior (">”) para atestar a diferença entre as médias dos grupos para cada variável. Estas diferenças serão utilizadas na análise dos grupos nas seções subsequentes.

Por exemplo, observa-se que para a variável Total de Unidades, o Grupo 1 difere-se dos Grupos 3, 4 e 5, apresentando um valor médio de número de unidades significantemente maior (a 10\%) do que os demais grupos. Ainda nesta variável, o Grupo 2 diferencia-se com uma taxa média maior em relação aos Grupos 4 e 5 . No entanto, os Grupos 1 e 2 não são significantemente diferentes entre si, assim como os Grupos 2 e 3. Também não é possível declarar que os Grupos 3, 4 e 5 diferem entre si.

Quadro 11 - Procedimento de Games-Howell (fonte: elaborado pelo autor)

\begin{tabular}{|l|c|c|c|c|c|}
\hline \multicolumn{1}{|c|}{ VARIÁVEIS } & \multicolumn{5}{c|}{ Grupos (Fatores) } \\
\cline { 2 - 6 } & $\mathbf{1}$ & $\mathbf{2}$ & $\mathbf{3}$ & $\mathbf{4}$ & $\mathbf{5}$ \\
\hline Idade & & $>1,3,4,5$ & & $>1,3,5$ & \\
Tempo de Franquia & $>2,3,4,5$ & $>1,3,4,5$ & & $>5$ & \\
Expansão Média & & & & \\
Novas Franquias & $>2,3,4,5$ & & & & \\
Dispersão & $>3,4,5$ & & & & $>1,2,4$ \\
Total de Unidades & $>3,4,5$ & $>4,5$ & $>1,2,4,5$ & & $>1,2,4$ \\
Instalação & & & $>1,2,4$ & & $>2,3,4$ \\
TXF & & & $>1,2,4,5$ & & \\
Royalties & & & & $>1,2,3,5$ & \\
Prazo de Contrato & & & & $>1,2,3,5$ & $>1,2,3,4$ \\
Mix Contratual & & & & & \\
Mercados Emergentes & & & & & \\
Shopping Center & & & & & \\
\hline Diferenças significantes a 10\% & & & & & \\
\hline
\end{tabular}

Frisa-se por fim que, em função das violações de pressupostos já indicadas, efetuou-se testes ANOVA individuais para cada variável. Os resultados foram idênticos àqueles indicados pelos resultados da MANOVA. 


\subsection{Nominação e Análise dos Grupos Estratégicos}

A Tabela 14 é similar à Tabela 11. No entanto, nela já aparecem os grupos (fatores) nominados conforme interpretação das estratégias latentes captadas nas varáveis pela análise de componente principal. O procedimento de identificação e análise seguem Carney e Gedajlovic (1991), os quais usam de abstrações teóricas para nominar os grupos.

Os 5 grupos foram designados respectivamente por (i) Rápido Crescimento, (ii) Maduras, (iii) Mais Franquia, (iv) Alto Investimento e (v) Metropolitanas. Cada uma delas será discutida em detalhes nas próximas seções.

Tabela 14 - Grupos estratégicos identificados na análise fatorial (fonte: elaborado pelo autor)

\begin{tabular}{l|c|c|c|c|c}
\hline \multirow{2}{*}{ Variáveis } & \multicolumn{5}{c}{ Componente (Fatores) } \\
\cline { 2 - 6 } & $\begin{array}{c}\text { Rápido } \\
\text { Crescimento }\end{array}$ & Maduras & $\begin{array}{c}\text { Alto } \\
\text { Investimento }\end{array}$ & $\begin{array}{c}\text { Mais } \\
\text { Franquia }\end{array}$ & Metropolitanas \\
\hline Novas Franquias & 0,90 & & & & \\
Expansão Média & 0,88 & & & & \\
Total de Unidades & 0,78 & 0,48 & & & \\
Dispersão & 0,73 & 0,46 & & 0,32 & \\
Tempo de Franquia & & 0,81 & & & \\
Idade & & 0,79 & 0,80 & & $-0,36$ \\
Instalação & & 0,73 & & 0,56 \\
Prazo de Contrato & & & 0,56 & 0,86 & \\
TXF & & & 0,74 & 0,64 \\
Mix Contratual & & & & & 0,59 \\
Mercados Emergentes & & & & & \\
Shopping Center & & & & & \\
Royalties & & & & & \\
\hline
\end{tabular}

A Tabela 15 contém dois conjuntos distintos de variáveis. Acima da faixa cinza (Crescimento) estão as variáveis empregadas na análise fatorial para constituição dos grupos. Assim é possível comparar as médias entre grupos, bem como traçar um paralelo com o Quadro 11, com os resultados do procedimento de Games-Howell na seção anterior.

Abaixo da faixa cinza estão as demais variáveis do estudo, as quais serão empregadas nos procedimentos econométricos no Capítulo 8. Embora estas medidas não tenham sido empregadas na análise fatorial, elas são uteis para auxiliar na identificação do perfil de cada grupo. Não constam na Tabela 15 as 
variáveis dicotômicas empregadas para os controles para setor e para processo de transformação nas lojas.

Por fim, a Tabela 16 indica o relacionamento entre os setores da indústria e os grupos. Como já mencionado, estes controles serão aplicados na análise do crescimento de redes no segundo estágio dos testes. 
Tabela 15 - Media dos valores para cada variável em cada grupo estratégico identificado (fonte: elaborado pelo autor)

\begin{tabular}{|c|c|c|c|c|c|c|}
\hline \multirow[t]{2}{*}{ Variáveis } & $\begin{array}{c}\text { Rápido } \\
\text { Crescimento }\end{array}$ & Maduras & Alto Investimento & Mais Franquia & Metropolitanas & Amostra \\
\hline & 38 & 71 & 50 & 110 & 107 & 376 \\
\hline Idade & 13,05 & 38,13 & 16,50 & 14,88 & 16,38 & 19,73 \\
\hline Tempo de Franquia & 7,42 & 16,48 & 9,18 & 9,40 & 7,43 & 9,95 \\
\hline Expansão Média & 19,47 & 2,61 & 3,22 & 3,40 & 2,46 & 4,58 \\
\hline Novas Franquias & 26,90 & 4,87 & 3,70 & 5,15 & 3,80 & 6,72 \\
\hline Total de Unidades & 227,58 & 107,63 & 61,22 & 42,75 & 33,67 & 73,55 \\
\hline Dispersão & $2.273 .837,91$ & $1.596 .175,77$ & $1.693 .259,26$ & $2.942 .036,11$ & $2.466 .728,98$ & $2.319 .045,89$ \\
\hline Instalação & 84,14 & 97,64 & 304,87 & 77,54 & 142,60 & 130,75 \\
\hline TXF & 22,64 & 26,34 & 51,98 & 25,55 & 43,91 & 34,14 \\
\hline Royalties & 0,10 & 0,08 & 0,07 & 0,07 & 0,13 & 0,09 \\
\hline Prazo de Contrato & 56,89 & 56,45 & 84,72 & 56,56 & 55,47 & 60,01 \\
\hline Mix Contratual & 0,76 & 0,76 & 0,71 & 0,93 & 0,69 & 0,78 \\
\hline Mercados Emergentes & 0,20 & 0,17 & 0,16 & 0,25 & 0,16 & 0,19 \\
\hline Shopping Center & 0,17 & 0,27 & 0,25 & 0,28 & 0,78 & 0,41 \\
\hline Crescimento & $117,7 \%$ & $15,4 \%$ & $20,3 \%$ & $31,1 \%$ & $31,5 \%$ & 0,36 \\
\hline Nível de Automação da Loja & $-0,11$ & $-0,09$ & 0,77 & 0,02 & $-0,28$ & 0,00 \\
\hline Densidade & 4,96 & 9,90 & 2,11 & 2,09 & 2,02 & 3,84 \\
\hline Suporte ao Franqueado & 3,13 & 1,25 & 2,25 & 2,32 & 2,50 & 2,24 \\
\hline$\Delta \_$Mix Contratual & 0,09 & 0,04 & 0,06 & 0,10 & 0,13 & 0,09 \\
\hline Cōnversão & 0 & $-0,27$ & 0,08 & 0,85 & 0,21 & 0,27 \\
\hline$\Delta \_$TXF & 0,02 & 0,12 & 0,02 & 0,06 & 0,04 & 0,06 \\
\hline$\Delta_{-}^{-}$Royalties & 0,19 & 0,14 & 0,05 & 0,00 & 0,17 & 0,10 \\
\hline Capital de Giro & 22,80 & 30,84 & 31,36 & 19,50 & 42,50 & 30,10 \\
\hline Faturamento Médio & 53,82 & 73,73 & 129,86 & 56,18 & 83,31 & 76,77 \\
\hline
\end{tabular}


Tabela 16 - Distribuição das redes entre os setores da indústria (fonte: elaborado pelo autor)

\begin{tabular}{l|c|c|c|c|c|c}
\hline \multicolumn{1}{c|}{ Setores } & $\begin{array}{c}\text { Rápido } \\
\text { Crescimento }\end{array}$ & Maduras & $\begin{array}{c}\text { Alto } \\
\text { Investimento }\end{array}$ & $\begin{array}{c}\text { Mais } \\
\text { Franquia }\end{array}$ & Metropolitanas & Amostra \\
\hline Alimentação & 8 & 24 & 26 & 29 & 41 & 128 \\
Estética & 3 & 6 & 4 & 10 & 5 & 28 \\
Instrução & 7 & 13 & 1 & 27 & 4 & 52 \\
Pessoa Jurídica & 0 & 2 & 3 & 3 & 1 & 9 \\
Setor de Saúde & 7 & 6 & 6 & 13 & 1 & 33 \\
Varejo \& Serviços & 4 & 7 & 7 & 12 & 8 & 38 \\
Vestuário & 9 & 13 & 3 & 16 & 47 & 88 \\
\hline Total & 38 & 71 & 50 & 110 & 107 & 376 \\
\hline
\end{tabular}

\subsubsection{Redes de Rápido Crescimento}

Em termos de ganho rápido de porte estas redes compõem uma espécie de elite entre as redes da amostra. Elas são as maiores em termos de números de unidades (média de 227 unidades). São também as que mais se expandem, tanto em termos de unidade totais como em novas franquias abertas. Além da expansão média histórica, estas redes são as que mais cresceram entre 2009 e 2011 (média de quase $118 \%$ para o período). Elas são ainda as mais jovens e as que, há menos tempo, têm adotado o modelo de franquias.

Isso parece indicar que estas redes desenvolveram uma linha de produtos e/ou formato de negócios extremamente atrativos, estabelecendo contratos de franquia em todo o território nacional. São as que mais cidades e mais estados ocupam. No entanto, não são as mais dispersas porque a distância média entre estas cidades e a sede destas redes é a menor da amostra. Seu formato de negócios é constituído de lojas relativamente pequenas, instaladas fora de centros comerciais.

Estas redes não só estruturam seu crescimento em lojas franqueadas como são as que mais converteram lojas próprias em franqueadas entre 2009 e 2011: em média, mais de duas unidades por rede (o que é irrisório frente ao porte médio destas redes).

Aqui, a atratividade do formato de negócio das redes aparece refletida no desembolso exigido de franqueados. Tanto a taxa fixa de franquia é a menor entre os grupos, com o valor para instalar uma loja sendo o segundo menor. No entanto, o 
movimento percebido é o de manutenção das taxas fixas de franquia com elevação dos royalties praticados, visto que estas são as redes que mais vêm elevando este tributo.

Outra característica marcante é o crescente aumento na oferta de suporte ao franqueado, o que provavelmente decorre da necessidade de coordenação e controle sobre a cadeia, Como previamente mencionado, assume-se que a maior oferta continua destes suportes permite ao franqueador transmitir as melhores práticas para a cadeia de franqueados, propiciando assim considerável controle no dia a dia da operação.

Suas lojas são relativamente pequenas, sendo as menores em termos de faturamento médio por loja. Mesmo com pouca presença em shopping centers (onde o tamanho das lojas tende a ser menor), o tamanho médio de loja destas redes (56 $\mathrm{m}^{2}$ ) somente supera o das lojas do grupo 5 (Metropolitanas), as quais são caracterizados por grande presença em shopping centers (onde tipicamente as lojas são pequenas).

O perfil da população das cidades ocupadas é o mais pobre entre os grupos, com média da parcela da população pertencente às classes $A$ e $B$ em $23 \%$, o que é fruto da presença de um número grande de lojas em cidades do interior ou em capitais de estados mais pobres. Quase $60 \%$ das lojas estão instaladas nas capitais dos estados ocupados, sendo que $75 \%$ estão distribuídas em estados das regiões Sul e Sudeste.

A Tabela 17 contém a matriz de correlações de Pearson para o grupo de Redes de Rápido Crescimento. Destacam-se as fortes associações negativas do prazo de contrato com o porte da rede $(\rho=-0,74)$, com a dispersão $(\rho=-0,51)$ e com os royalties praticados $(\rho=-0,69)$. Isso parece indicar que as redes procuram estabelecer relações de mais curto prazo, permitindo rápidas revisões de curso em mercados que cujo desempenho não tenha ocorrido a contento.

O crescimento vertiginoso destas redes é quase totalmente suportado por franqueados, o que pode ser visto na relação entre a taxa média de expansão e a abertura de taxa média de abertura de novas lojas franqueadas $(\rho=0,88)$. Além disso, a presença destas redes em mercados emergentes aparece forte e significantemente associada com quase todas as demais variáveis (principalmente 
com a proporção franqueada $-\rho=0,63)$, o que indica o perfil de ocupação estratégico das mesmas.

Tabela 17 - Matriz de correlações de Pearson - Variáveis usadas na análise fatorial, específicas para redes de Rápido Crescimento (fonte: elaborado pelo autor)

\begin{tabular}{l|rrrrrrrrrrrrr}
\hline \multicolumn{1}{c|}{ Variáveis } & \multicolumn{1}{c}{$\mathbf{1}$} & $\mathbf{2}$ & $\mathbf{3}$ & $\mathbf{4}$ & $\mathbf{5}$ & $\mathbf{6}$ & $\mathbf{7}$ & $\mathbf{8}$ & $\mathbf{9}$ & $\mathbf{1 0}$ & $\mathbf{1 1}$ & $\mathbf{1 2}$ & $\mathbf{1 3}$ \\
\hline 1. Idade & 1 & & & & & & & & & & & \\
2. Tempo Franq. & $\mathbf{0 , 6 4}$ & 1 & & & & & & & & & & \\
3. Exp. Média & $-0,13$ & 0,14 & 1 & & & & & & & & & \\
4. Novas Franquias & 0,01 & 0,07 & $\mathbf{0 , 8 8}$ & 1 & & & & & & & & \\
5. Dispersão & $\mathbf{0 , 5 3}$ & $\mathbf{0 , 6 5}$ & $\mathbf{0 , 3 5}$ & $\mathbf{0 , 4 6}$ & 1 & & & & & & & \\
6. Unid. Totais & $\mathbf{0 , 6 2}$ & $\mathbf{0 , 7 9}$ & 0,42 & $\mathbf{0 , 5 3}$ & $\mathbf{0 , 8 5}$ & 1 & & & & & & \\
7. Instalação & 0,14 & 0,17 & 0,04 & 0,04 & $-0,03$ & 0,05 & 1 & & & & & \\
8. TXF & $-0,23$ & $-0,17$ & $\mathbf{0 , 5 0}$ & $\mathbf{0 , 4 2}$ & $-0,22$ & $-0,09$ & 0,20 & 1 & & & & \\
9. Royalties & $\mathbf{0 , 4 6}$ & $\mathbf{0 , 3 6}$ & 0,12 & $\mathbf{0 , 3 7}$ & $\mathbf{0 , 5 1}$ & $\mathbf{0 , 6 3}$ & $-0,08$ & $-0,18$ & 1 & & & \\
1. Prazo & $\mathbf{- 0 , 4 8}$ & $-\mathbf{0 , 4 2}$ & $-0,16$ & $\mathbf{- 0 , 3 9}$ & $-\mathbf{0 , 5 1}$ & $\mathbf{- 0 , 7 4}$ & 0,17 & 0,18 & $\mathbf{- 0 , 6 9}$ & 1 & & \\
11. Prop. Franquia & 0,08 & $\mathbf{0 , 4 7}$ & $\mathbf{0 , 4 2}$ & $\mathbf{0 , 4 3}$ & $\mathbf{0 , 5 0}$ & $\mathbf{0 , 4 6}$ & 0,06 & 0,08 & 0,25 & $-0,12$ & 1 & \\
12. Merc. Emerg. & $\mathbf{0 , 3 3}$ & $\mathbf{0 , 4 8}$ & $\mathbf{0 , 4 2}$ & $\mathbf{0 , 4 7}$ & $\mathbf{0 , 6 1}$ & $\mathbf{0 , 5 4}$ & 0,23 & 0,02 & 0,26 & $-0,22$ & $\mathbf{0 , 6 3}$ & 1 \\
13. Shopping & 0,13 & 0,13 & 0,04 & 0,11 & 0,00 & 0,08 & 0,24 & 0,14 & 0,03 & $-0,03$ & 0,17 & 0,21 & 1 \\
\hline
\end{tabular}

É possível relacionar essas impressões com a dinâmica discutida na Seção 3.8. Ou seja, por serem jovens e ainda não lidarem com ativos tão específicos, a reversão de curso é possível, de forma que a rede tem incentivos em evitar contratos mais longos.

A relação negativa entre royalties e taxas fixas de franquias $(\rho=-0,18)$ também encontra suporte na visão tradicional de TA. Alguns trabalhos anteriores relacionando contratos de franquia em ECT propõem a taxa inicial fixa como um tipo de "refém" (hostage), o qual seria resgatado mediante um bom desempenho da unidade (DNES, 2003). Por outro lado, royalties permitiriam ao franqueador reter uma porção do resíduo das unidades, equilibrando incentivos entre as partes $(B R I C K L E Y, 2002)^{35}$. Considerando o ritmo de crescimento e dispersão destas redes, a estratégia de equilíbrio entre taxas fixas e variáveis parece ter sido um artefato conveniente para gestão do arranjo e consecução da estratégia.

${ }^{35}$ Esta é uma visão generalista da relação entre royalties e taxas fixas de franquia. Pesquisas mais específicas ponderam esta relação pelo nível de enforcement e controle de franqueadores sobre franqueados (HUANG, 1997; VÁSQUEZ, 2005, MARUYAMA; YAMASHITA, 2011). Por exemplo, em situações onde o franqueado retém um grau mais elevado de discricionariedade administrativa seria menos arriscado para as redes potencializarem incentivos na forma de royalties mais baixos, os quais seriam compensados por taxas fixas mais altas. 
Ainda com relação a royalties, segundo TA, na medida em que a rede se expande além dos grandes centros, um maior uso de franquias deveria ser esperado (RUBIN, 1978). Operar em mercados com estas características envolveria lidar simultaneamente como dificuldades de monitoramento e características locais que consomem tempo recursos para uma adequada adaptação da rede às condições locais.

Maiores taxas de royalties implicam uma maior parcela do resíduo abdicado pelo franqueado, elevando a probabilidade de falha da unidade (MICHAEL; COMBS, 2008). Em paralelo, existem indicações de que o nível de especificidade de ativos nestas redes seja baixo. Além de jovens, sem tempo suficiente para elevar a especificidade de seus ativos (ver discussão na Seção 3.8), o valor investido por franqueados é um dos menores entre os grupos, o que reduz o custo de saída para franqueados. Assim, é natural de este tipo de rede opere com prazos contratuais mais reduzidos.

Por fim, a Figura 8 representa graficamente o comportamento da proporção franqueada das redes deste grupo ao longo do tempo, juntamente com o número médio de unidades das redes ${ }^{36}$. A correlação entre estas duas curvas é de $92 \%$, suportando a perspectiva tradicional em TA quanto ao emprego de contratos de franquia em localidades distantes e menores (RUBIN, 1978).

Figura 7 - Comparação entre o crescimento do número de lojas e a evolução do mix contratual (fonte: elaborado pelo autor)

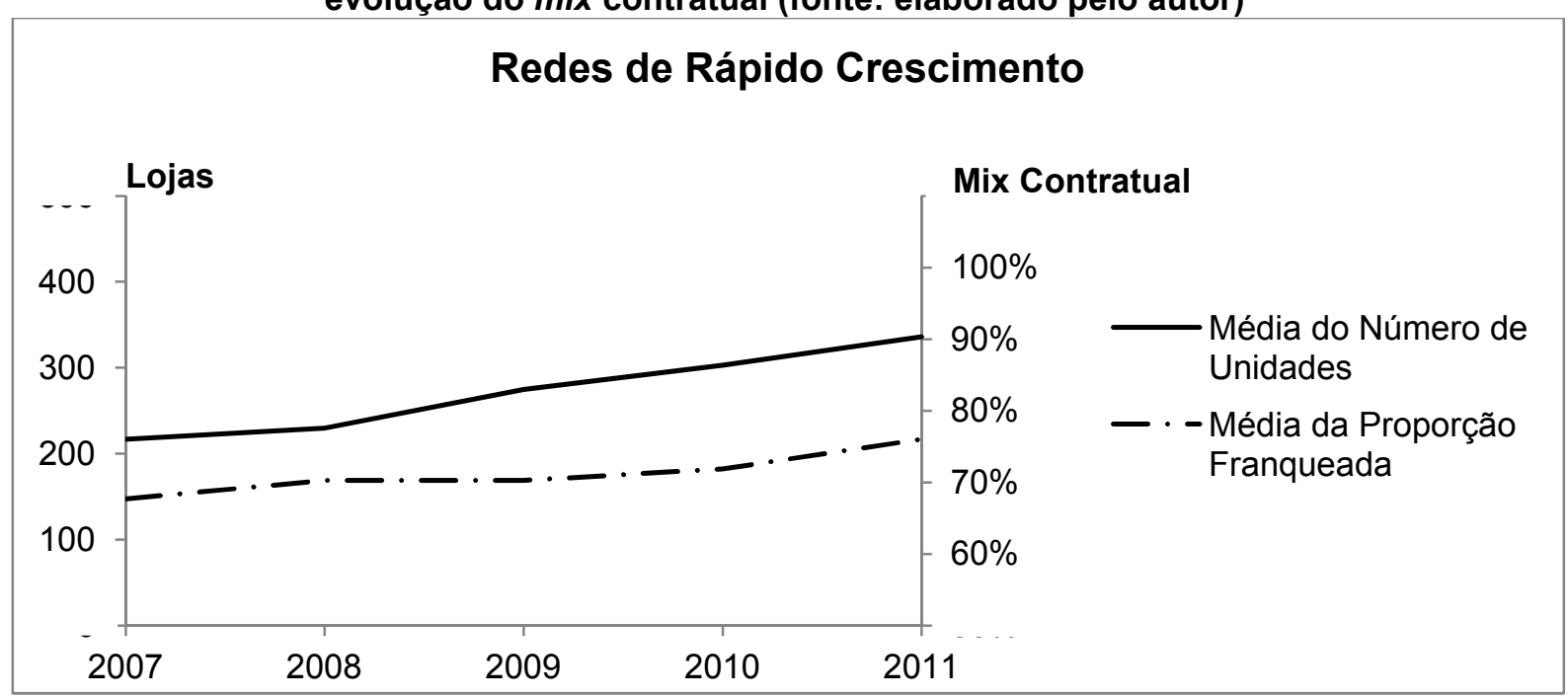

${ }^{36}$ Tanto neste grupo como nos demais, esta representação gráfica considera apenas aquelas redes que dispõem de dados entre 2006 e 2011, de forma que o gráfico se refere a uma subamostra. 


\subsubsection{Redes Maduras}

Estas redes caracterizam-se principalmente pela experiência, sendo as mais velhas e as que por mais tempo têm adotado o sistema de franquias. Elas ocupam o segundo lugar em número total de lojas e, dado o baixo ritmo de expansão, aparentam estar próximas do ponto de máxima em seu ciclo de vida.

Em média, estas redes têm em média 38 anos de existência e são as mais experientes quanto à adoção do modelo de franquias: pouco mais de 16 anos. Entre os grupos, este é o que menos se faz presentes nas capitais dos estados (em torno de $15 \%$ das lojas). Pouco mais de $76 \%$ das lojas estão concentradas nos estados das regiões Sul e Sudeste. A Tabela 18 contém os coeficientes de correlação de Pearson para as redes deste grupo.

A relação não significante entre idade e tempo de franquia resulta do tempo relativamente longo em que estas redes operaram apenas com lojas próprias (22 anos em média). Simultaneamente, a relação positiva e forte entre a taxa de abertura de novas franquias e a idade $(\rho=0,45)$ aponta para o uso do modelo de franquias para propiciar crescimento.

Tabela 18 - Matriz de correlações de Pearson - Variáveis usadas na análise fatorial, específicas para Redes Maduras (fonte: elaborado pelo autor)

\begin{tabular}{|c|c|c|c|c|c|c|c|c|c|c|c|c|c|}
\hline Variáveis & 1 & 2 & 3 & 4 & 5 & 6 & 7 & 8 & 9 & 10 & 11 & 12 & 13 \\
\hline 1. Idade & 1 & & & & & & & & & & & & \\
\hline 2. Tempo Franq. & 0,07 & 1 & & & & & & & & & & & \\
\hline 3. Exp. Média & 0,10 & 0,59 & 1 & & & & & & & & & & \\
\hline 4. Novas Franquias & 0,45 & 0,19 & 0,61 & 1 & & & & & & & & & \\
\hline 5. Dispersão & 0,14 & 0,56 & 0,86 & 0,48 & 1 & & & & & & & & \\
\hline 6. Unid. Totais & 0,24 & 0,63 & 0,96 & 0,67 & 0,84 & 1 & & & & & & & \\
\hline 7. Instalação & 0,26 & 0,05 & 0,03 & 0,08 & 0,01 & 0,08 & 1 & & & & & & \\
\hline 8. TXF & 0,18 & $-0,10$ & $-0,09$ & 0,00 & $-0,11$ & $-0,08$ & 0,59 & 1 & & & & & \\
\hline 9. Royalties & $-0,04$ & 0,32 & 0,32 & 0,05 & 0,37 & 0,25 & 0,24 & 0,11 & 1 & & & & \\
\hline 10. Prazo & 0,20 & $-0,11$ & 0,11 & 0,15 & 0,10 & 0,14 & 0,15 & 0,16 & 0,00 & 1 & & & \\
\hline 11. Prop. Franquia & 0,13 & 0,36 & 0,29 & 0,36 & 0,21 & 0,29 & $-0,26$ & $-0,04$ & 0,00 & $-0,11$ & 1 & & \\
\hline 12. Merc. Emerg. & 0,27 & 0,54 & 0,51 & 0,43 & 0,41 & 0,53 & 0,08 & $-0,02$ & 0,13 & $-0,04$ & 0,21 & 1 & \\
\hline 13. Shopping & 0,34 & $-0,06$ & $-0,02$ & 0,17 & $-0,05$ & 0,03 & 0,44 & 0,40 & 0,05 & 0,00 & $-0,12$ & 0,06 & 1 \\
\hline
\end{tabular}

Além disso, a ocupação de mercados emergentes aparece associada ao ciclo de vida das redes. Verificam-se correlações positivas fortes entre a presença em 
mercados emergentes e todas as variáveis relacionadas a ciclo de vida, porte e proporção franqueada.

Neste grupo a taxa fixa de franquia parece acompanhar o custo de instalação de uma loja $(\rho=0,59)$. No entanto, esta relação é modesta com o prazo de contrato (em torno de $15 \%$ aproximadamente). Royalties parecem relacionados ao tempo de franquia $(\rho=0,32)$, sinalizando que a reputação acumulada e/ou valor da marca são é capitalizados na forma de taxas variáveis (PENARD et al., 2003; POLOREDONDO et al., 2011)

Um aspecto da Teoria da Agência não suportado nestas redes tem a ver com a expectativa do uso de franquias em lojas cuja instalação é mais custosa. Esta hipótese tem sido corroborada em trabalhos ambientados em TA (COMBS; KETCHEN, 2003), mas não parece ser o caso aqui. A relação entre a proporção franqueada e o custo de instalação é negativa $(\rho=-0,26)$.

Essas redes são as que proporcionalmente mais têm investido na certificação do Selo de Excelência da ABF (cerca de $1 / 3$ das redes obteve certificação entre 2007 e 2011). No entanto, a oferta de suportes ao franqueado está abaixo da média da amostra, ao mesmo em que estas redes são as que menos aumentaram a oferta destes suportes entre 2009 e 2011.

O fato de não oferecer muitos suportes a franqueados não pode ser justificado por aspectos de inexperiência ou pouca idade, dado que estas redes são as mais velhas da amostra. Além disso, uma vez que o investimento em reputação é recorrente (através do Selo de Excelência em Franchising da ABF), ao contrário do que ocorre com suporte ao franqueado, parece ser o caso que este último está mais associado a aspectos de controle do que de reputação e atratividade a franqueados.

A Figura 9 compara a evolução do porte destas redes ao mix contratual ao longo do tempo. Estas redes são as que menos crescem na amostra, considerando tanto a média histórica como o período avaliado entre 2009 e 2011. Paralelamente, o mix contratual tem permanecido bastante estável. 
Figura 8 - Comparação entre o crescimento do número de lojas e a evolução do mix contratual - Redes Maduras (fonte: elaborado pelo autor)

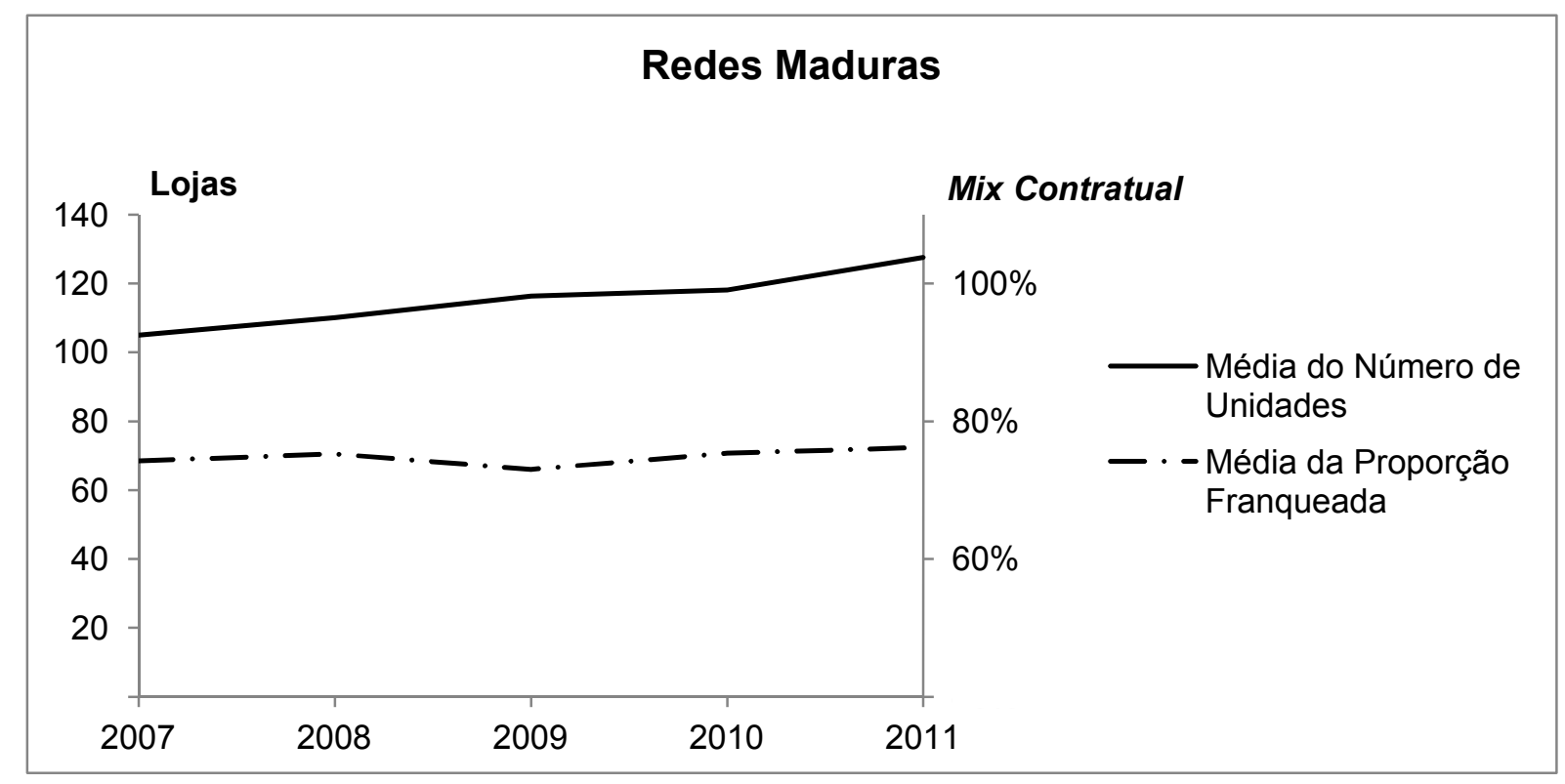

\subsubsection{Redes de Alto Investimento}

Estas redes buscam franqueados diferenciados em termos de capacidade gerencial e poder de investimento; características essas que potencialmente contribuiriam para o aumento de valor da rede (CARNEY; GEDAJLOVIC, 1991).

Estas redes apresentam os maiores custos de entrada para franqueados, tanto em relação à taxa fixa de franquia como para o investimento inicial para montagem da loja. A média total somada destes dois dispêndios (de quase $R \$ 350$ mil) representa mais que o dobro da média da amostra.

Até em função da necessidade de investimento, estas redes estabelecem suas lojas em cidades maiores e mais ricas. Em média, as cidades ocupadas têm média de população acima dos 2 milhões de habitantes (as maiores entre os grupos). A proporção representativa das classes A e B também é a maior da amostra: $26,7 \%$ em média.

Tanto o nível de automação nas lojas (destacada presença de maquinário) como o controle através de incremento ao suporte de franqueados são os maiores entre os grupos. Suas lojas são as maiores em área: cerca de $128 \mathrm{~m}^{2} \mathrm{em}$ média, com faturamento mensal médio de $\mathrm{R} \$ 130$ mil. 
Para ilustrar presença a complexidade da operação da loja típica dessas redes, criou-se um Índice Operacional ("I.O.") para lojas dividindo-se o capital de giro exigido pelas redes pelo produto da área com o número de funcionários:

$$
\text { I. } .=\left(\frac{\text { Capital de Giro }}{\text { Área de loja x Número de Funcionários }}\right)
$$

Para um mesmo montante exigido de capital de giro, quanto maior este índice, maior o uso do mesmo para manutenção de estoques. Reciprocamente, quanto menor o índice, maior o uso do capital de giro para folha de pagamento e manutenção de maquinaria, equipamentos e despesas relacionadas ao imóvel.

A Tabela 19 traz um comparativo entre os grupos para o índice e para o montante de capital de giro exigido. Observa-se que, simultaneamente, as redes de Alto Investimento exigem maior montante de capital de giro e apresentam o menor Índice Operacional. Ou seja, o investimento demandado é convertido em ativos físicos, seja na aquisição ou manutenção destes. Em comparação, por exemplo, com as redes Metropolitanas, o capital de giro demandado aparenta ser destinado à aquisição de estoques (como será discutido na próxima seção).

Tabela 19 - Índice Operacional (fonte: elaborado pelo autor)

\begin{tabular}{l|c|c}
\hline \multicolumn{1}{c|}{ Grupos } & I.O. & Capital de Giro \\
\hline Rápido Crescimento & 0,20 & 22,80 \\
Maduras & 0,16 & 30,84 \\
Alto Investimento & $\mathbf{0 , 0 6}$ & 31,36 \\
Mais Franquia & 0,15 & 19,50 \\
Metropolitanas & 0,29 & $42,50^{37}$ \\
\hline Total Geral & 0,19 & 30,10 \\
\hline
\end{tabular}

A Tabela 20 contém a matriz de correlações de Pearson para este grupo. Curiosamente, embora o valor investido pelo franqueado (taxa fixa + instalação) e o

\footnotetext{
${ }^{37}$ Nota-se uma correlação negativa entre prazos e proporção de lojas em shopping centers. Segundo apurado em entrevistas com executivos de empreendimentos como este, as redes são forçadas a oferecer contratos mais curtos para coincidi-los com o prazo de arrendamento do espaço no shopping center.
} 
prazo de contrato deem forma a este grupo, as correlações medidas indicam ambiguidade. A relação entre investimento inicial e o prazo de contrato é modesta, mas positiva. No entanto, a relação do prazo com a taxa fixa de franquia é negativa, indicando que, neste grupo, as redes com maiores taxas (incluindo royalties) oferecem contratos mais curtos.

TA recebe algum suporte neste grupo. O nível de dispersão geográfica está relacionado como esperado com o mix contratual $(\rho=0,41)$. Isso também é notado no uso de franquias para ocupar mercados emergentes $(\rho=0,42)$.

Tabela 20 - Matriz de correlações de Pearson - Variáveis usadas na análise fatorial, específicas para redes de Alto Investimento (fonte: elaborado pelo autor)

\begin{tabular}{|c|c|c|c|c|c|c|c|c|c|c|c|c|c|}
\hline Variáveis & 1 & 2 & 3 & 4 & 5 & 6 & 7 & 8 & 9 & 10 & 11 & 12 & 13 \\
\hline 1. Idade & 1 & & & & & & & & & & & & \\
\hline 2. Tempo Franq. & 0,61 & 1 & & & & & & & & & & & \\
\hline 3. Exp. Média & 0,20 & 0,52 & 1 & & & & & & & & & & \\
\hline 4. Novas Franquias & 0,17 & 0,40 & 0,90 & 1 & & & & & & & & & \\
\hline 5. Dispersão & 0,47 & 0,69 & 0,80 & 0,75 & 1 & & & & & & & & \\
\hline 6. Unid. Totais & 0,56 & 0,63 & 0,82 & 0,68 & 0,89 & 1 & & & & & & & \\
\hline 7. Instalação & 0,25 & 0,25 & 0,11 & $-0,01$ & 0,18 & 0,31 & 1 & & & & & & \\
\hline 8. TXF & 0,28 & 0,49 & 0,05 & $-0,04$ & 0,12 & 0,14 & 0,48 & 1 & & & & & \\
\hline 9. Royalties & $-0,16$ & $-0,21$ & 0,07 & 0,10 & $-0,01$ & 0,06 & 0,20 & $-0,13$ & 1 & & & & \\
\hline 10. Prazo & 0,20 & 0,18 & 0,25 & 0,17 & 0,33 & 0,42 & 0,11 & $-0,19$ & 0,20 & 1 & & & \\
\hline 11. Prop. Franquia & $-0,20$ & 0,35 & 0,25 & 0,43 & 0,23 & 0,02 & $-0,12$ & 0,17 & 0,06 & 0,10 & 1 & & \\
\hline 12. Merc. Emerg. & 0,26 & 0,36 & 0,30 & 0,42 & 0,47 & 0,36 & $-0,04$ & $-0,06$ & $-0,04$ & 0,39 & 0,43 & 1 & \\
\hline 13. Shopping & 0,23 & 0,08 & 0,08 & 0,09 & 0,13 & 0,12 & $-0,01$ & 0,07 & $-0,21$ & $-0,16$ & $-0,13$ & 0,01 & 1 \\
\hline
\end{tabular}

Mesmo considerando que os royalties praticados por estas redes estão entre os mais baixos entre os grupos ( $7 \%$ em média), a relação negativa com as taxas fixas é identificada $(\rho=-0,13)$, o que se alinha com a visão tradicional dos primeiros trabalhos em TA (BRICKLEY, 2002).

As redes que têm buscado mercados emergentes historicamente o fizeram através de lojas franqueadas, o que é verificado na relação entre a variável Mercados Emergentes e a proporção franqueada $(r=0,42)$, o que confirma o que é previsto em TA com relação a mercados alternativos (RUBIN, 1978). A Figura 10 compara a evolução do porte das redes com o mix contratual. 
Figura 9 - Comparação entre o crescimento do número de lojas e a evolução do mix contratual - Redes de Alto Investimento (fonte: elaborado pelo autor)

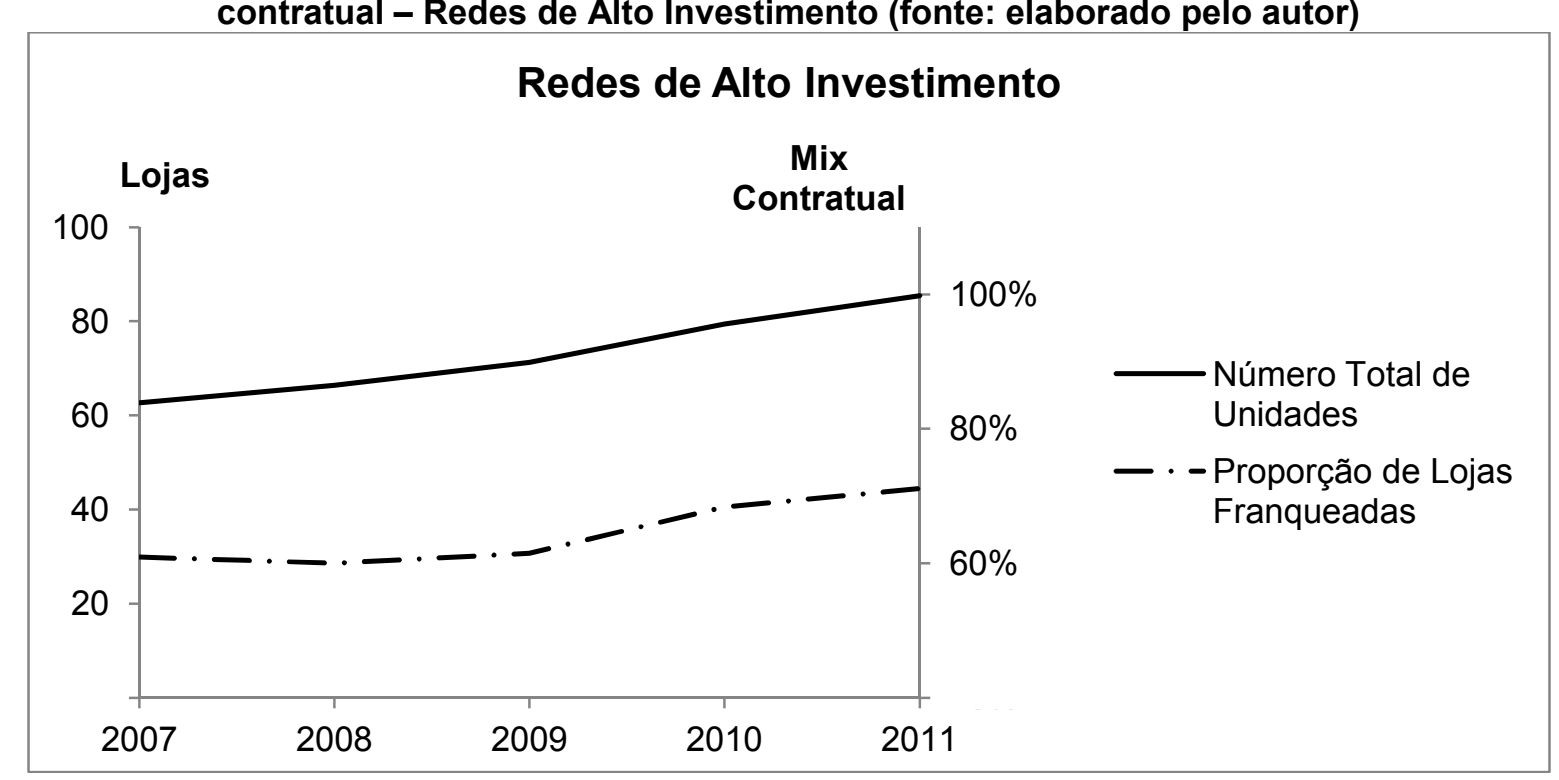

\subsubsection{Mais Franquia}

Este é o maior grupo em número de redes, bem como aquele cujos valores das variáveis em análise mais se aproximam da média da amostra. Uma característica destacada é a maior proporção franqueada em média (93\%), daí o nome do grupo. Estas redes são as que levaram menos tempo para aderirem ao modelo de franquias (pouco mais de 5 anos). São também as que mais se aventuraram proporcionalmente em mercados emergentes.

Embora não sejam as mais dispersas em quilômetros, são as menos densas da amostra, com média de 2 lojas por cidade ocupada, ainda que não sejam tão grandes em porte (43 unidades em média).

Estas redes são as que menos demandam investimento do franqueado, o que poderia levar a associá-las às redes "unsuccessful" indicadas em Carney e Gedajlovic (1991). No entanto, elas exibem um crescimento médio de $30 \%$ no período analisado, não sendo as que menos cresceram no período.

Elas são as mais atrativas do ponto de vista do custo de entrada para franqueados. Apresentam o menor custo de instalação e a segunda menor taxa fixa 
de franquia. Seus royalties também são os menores e, em todas as redes do grupo, estão estáveis pelo menos desde 2009. A Tabela 21 contém a matriz de correlações de Pearson deste grupo.

Tabela 21 - Matriz de correlações de Pearson - Variáveis usadas na análise fatorial, específicas para redes Mais Franquia (fonte: elaborado pelo autor)

\begin{tabular}{|c|c|c|c|c|c|c|c|c|c|c|c|c|c|}
\hline Variáveis & 1 & 2 & 3 & 4 & 5 & 6 & 7 & 8 & 9 & 10 & 11 & 12 & 13 \\
\hline 1. Idade & 1 & & & & & & & & & & & & \\
\hline 2. Tempo Franq. & 0,68 & 1 & & & & & & & & & & & \\
\hline 3. Exp. Média & $-0,34$ & $-0,09$ & 1 & & & & & & & & & & \\
\hline 4. Novas Franquias & $-0,06$ & $-0,31$ & 0,69 & 1 & & & & & & & & & \\
\hline 5. Dispersão & 0,01 & 0,13 & 0,64 & 0,47 & 1 & & & & & & & & \\
\hline 6. Unid. Totais & 0,27 & 0,34 & 0,70 & 0,63 & 0,70 & 1 & & & & & & & \\
\hline 7. Instalação & 0,11 & 0,08 & 0,03 & 0,10 & 0,12 & 0,20 & 1 & & & & & & \\
\hline 8. TXF & 0,07 & 0,13 & 0,02 & 0,02 & 0,14 & 0,10 & 0,45 & 1 & & & & & \\
\hline 9. Royalties & 0,09 & 0,12 & $-0,18$ & $-0,14$ & 0,05 & $-0,09$ & 0,00 & 0,06 & 1 & & & & \\
\hline 10. Prazo & $-0,16$ & $-0,27$ & $-0,02$ & 0,08 & 0,03 & $-0,15$ & 0,20 & 0,29 & $-0,01$ & 1 & & & \\
\hline 11. Prop. Franquia & 0,11 & 0,29 & 0,26 & 0,21 & 0,19 & 0,33 & 0,04 & 0,03 & 0,10 & $-0,19$ & 1 & & \\
\hline 12. Merc. Emerg. & 0,21 & 0,30 & 0,16 & 0,05 & 0,12 & 0,23 & 0,02 & 0,08 & 0,09 & $-0,13$ & $-0,16$ & 1 & \\
\hline 13. Shopping & 0,15 & 0,10 & 0,04 & 0,10 & 0,09 & 0,14 & 0,50 & 0,28 & $-0,07$ & 0,11 & 0,07 & 0,05 & 1 \\
\hline
\end{tabular}

Curiosamente, apesar da maior dispersão em termos de distância entre as lojas, estas redes estão abaixo da média em termos de número de estados e de cidades ocupadas (em média, 24 cidades em praticamente 8 estados). Isso indica forte presença em capitais e cidades mais ricas. Como ilustração disso, essas redes são as que mais possuem sede e operações na região Sul do Brasil.

Estas redes estão em segundo lugar na disposição de lojas em shopping centers (cerca de $28 \%$ das lojas). Embora os custos iniciais de instalação do franqueado estejam entre os menores, redes com maior presença em shoppings praticam valores maiores de taxas fixas. Como esperado, o valor de instalação tem associação positiva com shopping em função do desembolso necessário com taxas e luvas relativas a este tipo de empreendimento.

A Figura 11 compara mix contratual e a evolução do porte destas redes. A correlação entre as duas curvas é de $92 \%$, indicando que o aumento da proporção franqueada vem subsidiando o ganho de porte destas redes. 
Figura 10 - Comparação entre o crescimento do número de lojas e a evolução do mix contratual - Redes Mais Franquia (fonte: elaborado pelo autor)

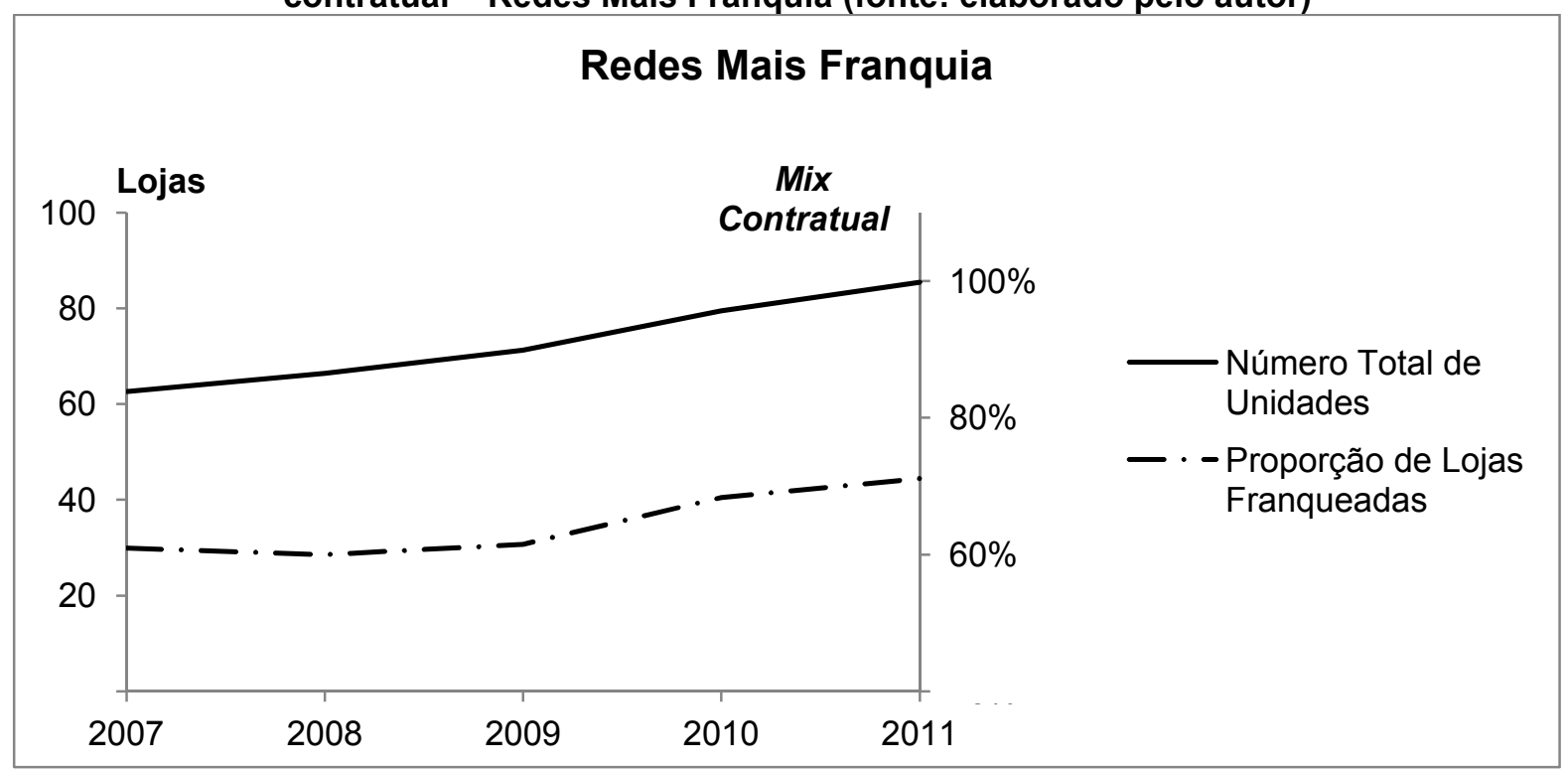

\subsubsection{Redes Metropolitanas}

A principal característica destas redes é a grande presença de suas lojas em shopping centers (78\% em média). Empreendimentos como estes propiciam um tipo de demanda forçada, decorrente da atração de consumidores pelas chamadas lojas âncora $^{38}$. Consequentemente, o desempenho em vendas tende a ser melhor, abrindo espaço para royalties e taxas fixas mais elevadas (CARTER; VANDELL, 2005).

Os contratos de menor duração dentre os grupos também são influenciados pela presença em shopping centers, tendo em vista que os contratos de locação de lojas satélite tendem a ser de, no máximo, cinco anos. A Figura 12 compara o crescimento do número médio de unidades por rede ao crescimento do setor de shopping centers no Brasil. A correlação das curvas é de 96\% (fonte: Associação Brasileira de Shopping Centers - ABRASCE, 2012).

\footnotetext{
${ }^{38}$ Grandes lojas de departamentos ou espaços como cinemas, academias de ginástica, áreas de jogos, dentre outros.
} 
Figura 11 - Comparação entre o crescimento do número de lojas e o crescimento no setor de shopping centers (fonte: elaborado pelo autor)

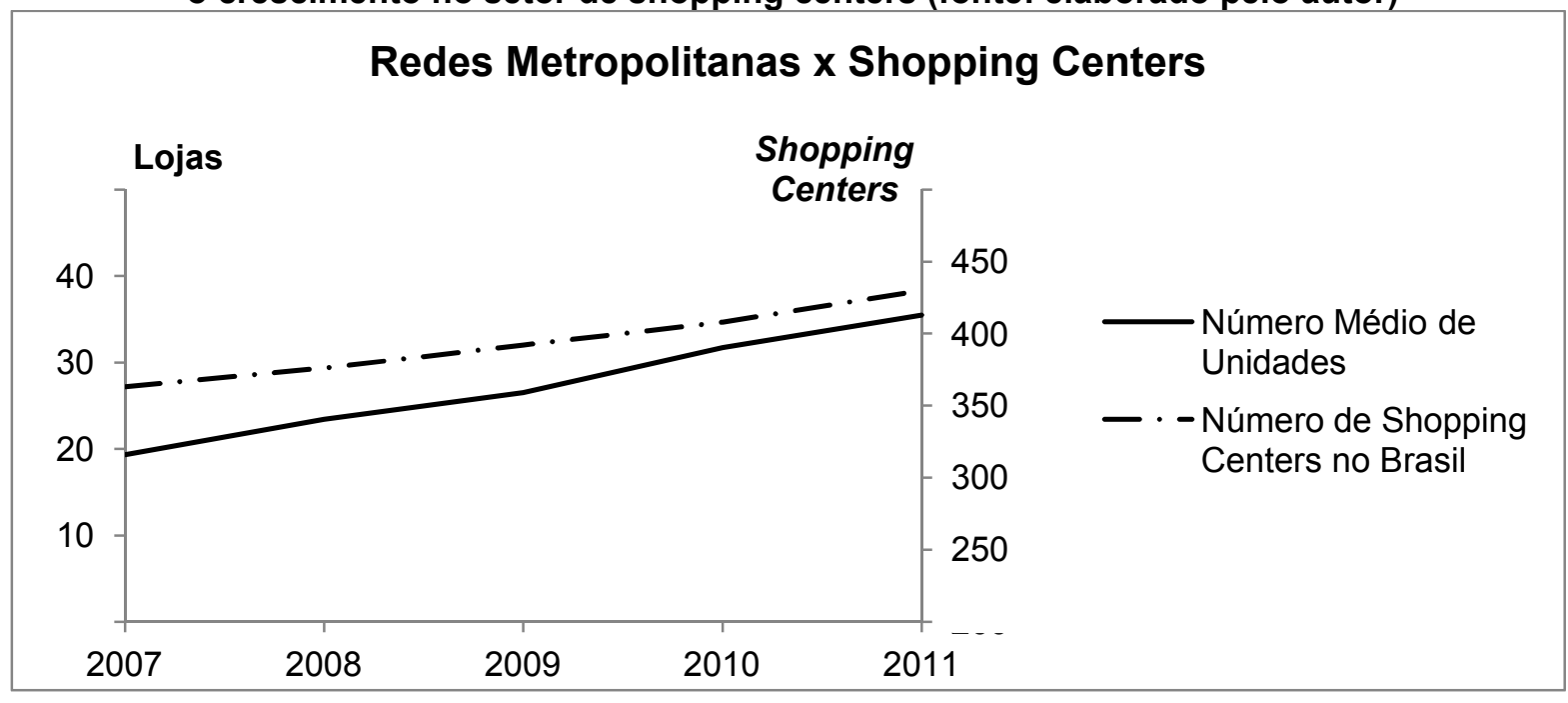

A estrita ligação do formato de negócios destas redes com o setor de shopping centers acaba por limitar as oportunidades para o estabelecimento de suas lojas. Não por acaso, este grupo apresenta o menor número médio de unidades e a menor média histórica de expansão. Também são as redes com maior presença de lojas nas regiões Centro-Oeste, Norte e Nordeste (cerca de 30\%). Aproximadamente $16 \%$ destas redes têm sede em estados do Nordeste.

Apesar da maior presença em regiões menos ricas, a proporção da população das cidades ocupadas pertencentes às classes $A$ e $B$ é a segunda maior da amostra, indicando a presença das lojas nas capitais, cidades mais ricas do interior e balneários turísticos (o que acaba resultando na menor densidade de lojas comparada ao total da população).

Cerca de $90 \%$ das redes deste grupo pertencem aos setores e alimentação e vestuário. Ou seja, existe forte necessidade de imobilização de ativos, seja em maquinário e/ou em estoques de produtos acabados. Não por acaso, as medidas estabelecidas para captar o impacto da especificidade de ativos é a maior entre os grupos.

Também a medida colocada para captar a redução do efeito da dispersão pela presença de maiores níveis de automação se destaca entre as demais redes. Segundo a perspectiva de TA, isso aliviaria a necessidade de investir em mecanismos de incentivo, dado que o monitoramento a distância é mais eficiente. A maior média de royalties praticados e a menor proporção de lojas franqueadas 
parecem corroborar esta hipótese. No entanto, nota-se que estas redes são as que mais vêm aumentando esta proporção entre 2009 e 2011. A Tabela 22 contém a matriz de correlação de Pearson para este grupo.

Tabela 22 - Matriz de correlações de Pearson - Variáveis usadas na análise fatorial, específicas para Redes Metropolitanas (fonte: elaborado pelo autor)

\begin{tabular}{|c|c|c|c|c|c|c|c|c|c|c|c|c|c|}
\hline Variáveis & 1 & 2 & 3 & 4 & 5 & 6 & 7 & 8 & 9 & 10 & 11 & 12 & 13 \\
\hline 1. Idade & 1 & & & & & & & & & & & & \\
\hline 2. Tempo Franq. & 0,29 & 1 & & & & & & & & & & & \\
\hline 3. Exp. Média & $-0,25$ & 0,09 & 1 & & & & & & & & & & \\
\hline 4. Novas Franquias & 0,18 & $-0,09$ & 0,67 & 1 & & & & & & & & & \\
\hline 5. Dispersão & 0,16 & 0,32 & 0,62 & 0,65 & 1 & & & & & & & & \\
\hline 6. Unid. Totais & 0,24 & 0,37 & 0,74 & 0,75 & 0,80 & 1 & & & & & & & \\
\hline 7. Instalação & 0,18 & 0,06 & $-0,06$ & 0,04 & $-0,10$ & $-0,02$ & 1 & & & & & & \\
\hline 8. TXF & 0,08 & 0,11 & $-0,05$ & $-0,05$ & $-0,12$ & $-0,02$ & 0,12 & 1 & & & & & \\
\hline 9. Royalties & 0,16 & 0,08 & 0,18 & 0,32 & 0,45 & 0,23 & $-0,24$ & 0,15 & 1 & & & & \\
\hline 10. Prazo & $-0,08$ & $-0,03$ & $-0,05$ & $-0,01$ & $-0,02$ & $-0,10$ & 0,11 & $-0,05$ & $-0,07$ & 1 & & & \\
\hline 11. Prop. Franquia & 0,04 & 0,27 & 0,30 & 0,46 & 0,30 & 0,33 & 0,04 & 0,01 & 0,05 & 0,20 & 1 & & \\
\hline 12. Merc. Emerg. & 0,22 & 0,18 & 0,35 & 0,41 & 0,50 & 0,45 & $-0,12$ & 0,03 & 0,30 & 0,17 & 0,25 & 1 & \\
\hline 13. Shopping & $-0,05$ & 0,16 & 0,06 & 0,03 & $-0,07$ & 0,05 & 0,28 & $-0,25$ & $-0,43$ & 0,45 & 0,22 & $-0,09$ & 1 \\
\hline
\end{tabular}

Nota-se uma inesperada associação entre taxas e royalties praticados e a presença mais intensa em shopping centers $(\rho=-0,43)$. Ou seja, embora estas redes sejam caracterizadas por maiores taxas praticadas sobre franqueados, aquelas com mais presença em shopping centers praticam as menores taxas. $O$ mesmo ocorre com o prazo de contrato $(\rho=0,45)$.

São as redes com o menor número de certificações do Selo de Excelência da $\mathrm{ABF}$, mas estão entre as que mais vêm aumentando a oferta de suporte ao franqueado. Este antagonismo é interpretado inferindo-se que o acúmulo de capital reputacional advém da própria presença em shopping centers, enquanto o uso a oferta de suportes constitui mecanismos de controle e transmissão de conhecimento.

A Figura 13 compara as curvas do porte e do mix contratual ao longo do tempo. A correlação entre estas curvas é de $99 \%$, ilustrando o fato de estas redes serem as que mais vêm aumentando a proporção franqueada no período analisado. 
Figura 12 - Comparação entre o crescimento do número de lojas e a evolução do mix contratual - Redes Metropolitanas (fonte: elaborado pelo autor)

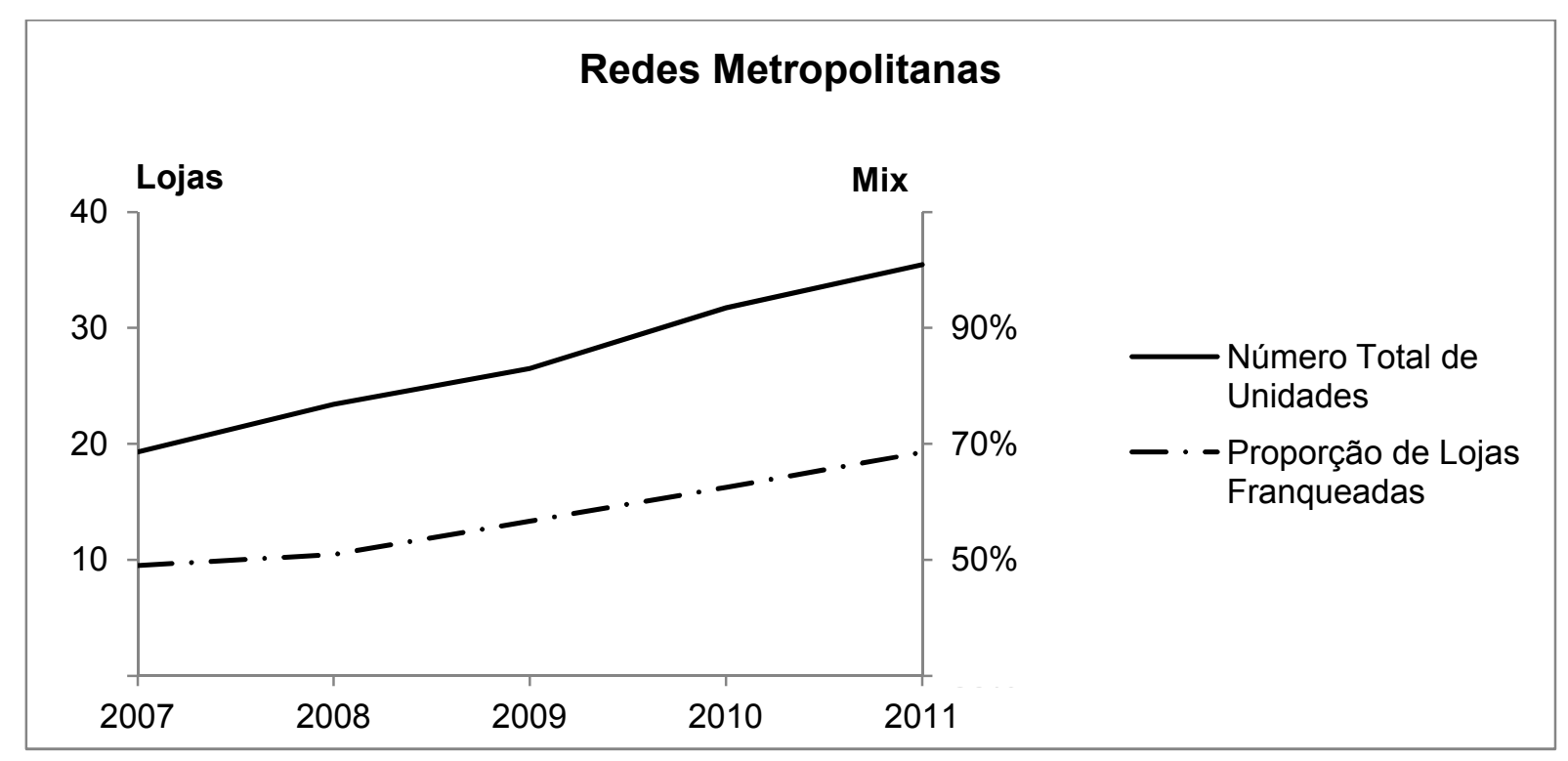




\section{DETERMINANTES DO CRESCIMENTO}

Nesta etapa do trabalho verifica-se se variáveis representando o modelo de operações das redes conseguem explicar o engajamento das redes aos seus respectivos grupos. $O$ procedimento consiste em considerar como variável dependente a probabilidade da rede estar engajada em seu respectivo grupo.

A Tabela 23 contém a matriz de correlações de Pearson para todas as variáveis utilizadas nesta etapa da análise. Frisa-se que a estatística descritiva destas variáveis já consta na Tabela 7 . As variáveis dicotômicas não estão representadas.

Tabela 23 - Matriz de correlações de Pearson para as variáveis empregadas na análise dos determinantes do crescimento (fonte: elaborado pelo autor)

\begin{tabular}{l|rrrrrrrrrr}
\hline \multicolumn{1}{c|}{ Variáveis } & \multicolumn{1}{c|}{$\mathbf{1}$} & $\mathbf{2}$ & $\mathbf{3}$ & $\mathbf{4}$ & $\mathbf{5}$ & $\mathbf{6}$ & $\mathbf{7}$ & $\mathbf{8}$ & $\mathbf{9}$ & $\mathbf{1 0}$ \\
\hline 1. Crescimento & 1 & & & & & & & & & \\
2. Nível de Automação da Loja & $-0,04$ & 1 & & & & & & & \\
3. Densidade & $-0,01$ & $-0,03$ & 1 & & & & & & \\
4. Suporte ao Franqueado & 0,30 & $-0,01$ & 0,01 & 1 & & & & & \\
5. $\boldsymbol{\Delta}$ Mix Contratual & 0,20 & $-0,07$ & $-0,01$ & 0,33 & 1 & & & & \\
6. Conversão & $-0,02$ & $-0,01$ & 0,00 & 0,14 & 0,11 & 1 & & & \\
7. $\Delta$ _TXF & 0,01 & $-0,04$ & $-0,03$ & $-0,03$ & $-0,01$ & 0,04 & 1 & & \\
8. $\boldsymbol{\Delta}$ Royalties & 0,23 & $-0,04$ & $-0,01$ & 0,25 & 0,40 & 0,00 & $-0,03$ & 1 & \\
9. Capital de Giro & $-0,07$ & $-0,16$ & $-0,02$ & 0,00 & $-0,08$ & $-0,03$ & 0,05 & $-0,04$ & 1 \\
10. Faturamento Médio & $-0,05$ & 0,11 & $-0,01$ & $-0,07$ & $-0,06$ & $-0,10$ & $-0,01$ & $-0,03$ & 0,36 & 1 \\
\hline Significante a 5\% para todo $\boldsymbol{\rho}>0, \mathbf{1}$
\end{tabular}

Verifica-se que nenhuma variável apresenta correlação acima de $50 \%$, o que é uma indicação de ausência de auto correlação nos dados. Por sua vez, o tamanho da amostra alivia a restrição da normalidade multivariada para os testes subsequentes. Questões relativas à heterocedasticidade e multicolinearidade serão discutidas ao longo da análise dos testes.

\section{1. $1^{\circ}$ Estágio - Modelo Multinomial Logit}

Como já mencionado anteriormente, tanto a análise fatorial como o modelo probit indicam que algumas redes apresentam elevada probabilidade de estarem engajadas em mais de um grupo estratégico. Assim, um procedimento específico é 
aplicado para esta condição: uma regressão multinominal logit ${ }^{39}$, também chamado de modelo logit múltiplo, ou simplesmente "mlogit" (DAVIDSON; MACKINNON, 2004, p. 460).

O modelo assume que as observações possuem valores que não se repetem entre si, isto é, cada variável independente assume um valor distinto para cada caso. O modelo também assume que a variável dependente não pode ser perfeitamente prevista a partir das variáveis independentes.

Como no presente caso, quando o modelo multinomial logit é usado para modelar escolhas ele usa o pressuposto da Independência de Alternativas Irrelevantes (IAI), o que nem sempre é desejável. Isso implica que chances não dependem das demais alternativas.

A variável dependente (os grupos) varia de $t=0,1, \ldots, J$, sendo 0 a categoria de referência. Aplica-se uma regressão para cada categoria de forma a prever a probabilidade de $Y_{t}$ (variável dependente para qualquer observação $t$ ) estar nessa categoria. A probabilidade de $Y_{t}$ pertencer à categoria de referência (0) é obtida adicionando-se a restrição de que a soma das probabilidades de ser igual a um (DAVIDSON; MACKINNON, 2004, p. 461). As regressões são expressas por:

$$
P\left(Y_{t}=l\right)=\frac{\exp \left(\beta_{l} X_{t}\right)}{1+\sum_{j=1}^{J} \exp \left(\beta_{j} X_{t}\right)}, \quad \text { para } t=0, \ldots, J
$$

No presente caso, $j$ varia de 0 a 5 (os 5 grupos, além do conjunto de redes que não se engajou em nenhum grupo), $X_{t}$ representa o vetor com as variáveis explicativas e $\beta$ o vetor de parâmetros a serem estimados. Tendo a variável resposta $j$ categorias, devem-se estimar $j-1$ equações porque um dos grupos é usado como categoria de referência.

A regressão multinomial logit contribui com a pesquisa de duas formas. Primeiramente, é verificado se e quais variáveis relacionadas ao modelo de operações e ciclo de vida conseguem explicar os grupos formados pela análise fatorial. Em segundo lugar, a probabilidade estimada para cada rede será usada

\footnotetext{
39 Inicialmente procurou-se aplicar uma regressão probit multinomial (mprobit), mas o pacote estatístico empregado no teste não identificou concavidade no teste probabilístico.
} 
para cálculo da razão inversa de Mills, a qual será inserida nas regressões MQO para mensuração da influência do engajamento aos grupos sobre o crescimento das redes.

\subsection{Resultados da Multinomial Logit}

O principal output da regressão multinomial logit é medir a probabilidade de que uma rede pertença a cada um dos grupos previstos pela análise fatorial, porém com base em um conjunto distinto de variáveis. Ou seja, enquanto na análise fatorial as variáveis empregadas para constituição dos grupos relacionam-se com estratégias deliberadas pelas redes para condução de suas operações, neste estágio empregam-se varáveis relacionadas ao modelo de operações e ao ciclo de vida destas redes.

A variável dependente é a identificação numérica dada aos grupos. Ou seja, (1) Rápido Crescimento, (2) Maduras, (3) Alto Investimento, (4) Diversificadas e (5) Metropolitanas.

O pacote estatístico empregado na análise gera cinco colunas de dados com a probabilidade estimada para cada rede em pertencer a cada um dos grupos. A soma de todas as probabilidades em cada rede ao longo dos grupos é igual a um.

O principal parâmetro analisado no teste é a significância geral da regressão, bem como a probabilidade estimada de que a rede esteja associada ao grupo previsto no $1^{\circ}$ estágio. No caso, o nível de acurácia é de $65,7 \%$, ou seja, das 376 redes da amostra, 247 apresentaram uma maior probabilidade de pertencerem ao grupo previsto na análise fatorial em comparação aos demais 4 grupos.

Existe um aspecto importante nestas redes cuja associação aos grupos não foi confirmada. Os atributos que denotam estas redes não são fortemente identificados com o perfil típico dos grupos, de forma que o comportamento estratégico decorrente do ciclo de vida parece ainda ser difuso. Ainda assim, optouse por manter estas redes no restante da análise, aceitando-se a identificação obtida na análise fatorial.

O Pseudo $R^{2}$ do modelo é de $41,26 \%$, sendo o mesmo significante a $1 \%$. Frisa-se que os resultados individuais com relação ao valor, sinal e significância dos 
coeficientes não têm importância neste teste, mas sim a significância total do modelo, bem como as probabilidades estimadas.

Em função da heterocedasticidade verificada nos dados, o modelo foi estabelecido com erros padrão com a correção de White para este problema, comumente chamado de erro padrão robusto, como indicado em Gujarati (2006, p. 337). Os erros padrão de White são consideravelmente maiores do que aqueles obtidos na regressão, de forma que os valores t ou z obtidos são muito menores.

\subsection{Cálculo da Razão Inversa de Mills}

Como mencionado na Seção 4.8, para regredir os atributos da transação (produto/processo) contra medidas de desempenho (no caso, o crescimento), tornase necessário controlar para o viés de seleção e endogeneidade presente nos dados.

É possível (ou provável) que os atributos mencionados acima determinem a associação das redes a seus respectivos grupos. Ou seja, em função de características operacionais e estratégica, uma rede pertence ao grupo 1 ao invés dos demais.

Assim, se fosse aplicado um teste regredindo-se medidas de crescimento das redes contra seus atributos sem que se considerasse a associação das mesmas aos respectivos grupos, assumir-se-ia que o fato da rede pertencer a determinado grupo seria aleatório. Ou, estatisticamente, o termo de erro da regressão seria $e=0$, o que é bem pouco realista.

Ao contrário, espera-se $e \neq 0$. Ou seja, existem aspectos não observáveis na tomada de decisão das redes que a influenciam a se engajar no comportamento típico de determinado grupo. Como não são observáveis e, portanto, não passíveis de serem considerados no modelo de análise de crescimento, estes aspectos precisam ser controlados no modelo. Para tal, emprega-se o modelo de Heckman (1974, 1976), o qual sugere a razão inversa de Mills para problemas de endogeneidade e viés amostral. 
Assim esta etapa consiste em calcular a razão inversa de Mills com base na probabilidade estimada na etapa anterior. Como já mencionado, ela é expressa por:

$$
\lambda=\rho_{\eta} \frac{\phi\left[\left(\beta_{2}-\beta_{1}\right) X\right]}{\Phi\left[\left(\beta_{2}-\beta_{1}\right) X\right]}
$$

Uma vez que $P(X)=\left(\beta_{2}-\beta_{1}\right) X$, tem-se que:

$$
\lambda=\rho_{\eta} \frac{\phi[P(X)]}{\Phi[(P) X]}
$$

Como a correlação entre os erros $\rho_{\eta}=1$, para cada grupo, $\lambda$ é calculada com base na probabilidade de que cada rede pertença àquele grupo, independente do resultado previsto na análise fatorial. Como mencionado anteriormente:

$$
\sum P\left(X_{i}\right)=1, \quad i=\{1,2,3,4,5\}
$$

Com $P\left(X_{i}\right)$ representando a probabilidade de a rede pertencer ao i-ésimo grupo. Dessa forma, para cada rede haverá cinco valores da razão inversa de Mills. Quando da inserção desse valor nas regressões MQO, será considerado apenas aquele referente ao grupo previsto desde a análise fatorial. Por exemplo, se uma rede foi associada ao grupo das redes de Rápido Crescimento (grupo 1), mas a mlogit o associou ao grupo de redes Maduras (grupo 2), ainda assim, o valor da razão inversa de Mills considerada será aquela calculada com a probabilidade medida de a rede pertencer ao grupo 1.

A existência do viés de seleção é então verificada a partir da significância estatística da razão inversa de Mills. Se $\lambda$ for significativo, a existência do viés de seleção é estatisticamente detectada, demonstrando que a aplicação da regressão MQO convencional geraria estimadores com viés. Entretanto, a presença desse termo na equação elimina o viés de seleção. 
Reciprocamente, a não significância estatística do termo demonstra que o viés de seleção não existe. Se a estimativa do parâmetro da razão inversa de Mills é igual a zero, não há viés de seleção e os parâmetros podem ser estimados de forma consistente por mínimos quadrados usando a amostra selecionada (WOOLDRIDGE, 2006, p. 554). Assim, em termos práticos, o sinal esperado para $\lambda$, quando significante, é negativo.

\section{4. $2^{\circ}$ Estágio - Modelos MQO de Crescimento}

O terceiro e último estágio do processo de análise dos determinantes do crescimento das redes de franquia consiste em modelos MQO individuais para os grupos. Nestas regressões não são inseridas as variáveis de controle. Na ausência das variáveis instrumentais sugeridas por Yvrande-Billon e Saussier (2004), se aceita a sugestão de Wooldridge (2006, p. 516) de se trabalhar com um número maior de variáveis no primeiro estágio (mlogit) em relação às regressões MQO usadas para avaliar desempenho (no presente caso, o crescimento). Assim, optouse por manter os controles apenas na mlogit.

O efeito das variáveis de controle necessárias para diferenciar aspectos idiossincráticos entre redes e setores estará absorvido e controlado na razão inversa de Mills, a qual se apura com a probabilidade medida com que cada rede está associada aos grupos.

A Tabela 24 apresenta os resultados das regressões MQO para os cinco grupos. Processos de dois estágios como este precisam controlar para o erro da regressão que é arrastado de uma estagio para o outro (no caso, da mlogit para os modelos MQO). Também aqui, aplicou-se o erro padrão robusto para este fim (além de controlar problemas de heterocedasticidade já mencionados).

Foram conduzidos testes de normalidade multivariada para os grupos. A hipótese de que os dados apresentam normalidade multivariada foi rejeitada, o que constitui a violação desta premissa. Esse não chega a ser um problema para os grupos das redes Mais Franquia e Metropolitanas (possuem mais de 100 observações), mas precisa ser ponderado principalmente no grupo das redes de Rápido Crescimento. 
Tabela 24 - Resultados dos modelos MQO aplicados sobre os grupos (fonte: elaborado pelo autor)

\begin{tabular}{|c|c|c|c|c|c|}
\hline Variáveis & $\begin{array}{c}\text { Rápido } \\
\text { Crescimento }\end{array}$ & Maduras & $\begin{array}{c}\text { Alto } \\
\text { Investimento }\end{array}$ & $\begin{array}{c}\text { Mais } \\
\text { Franquia }\end{array}$ & Metropolitanas \\
\hline $\begin{array}{l}\text { Nível de } \\
\text { Automação na Loja }\end{array}$ & $\begin{array}{c}0,14 \\
(0,72)\end{array}$ & $\begin{array}{c}0,02 \\
(0,03)\end{array}$ & $\begin{array}{c}{ }^{* *}-0,03 \\
(0,02)\end{array}$ & $\begin{array}{c}0,00 \\
(0,06)\end{array}$ & $\begin{array}{l}-0,05 \\
(0,04)\end{array}$ \\
\hline Densidade & $\begin{array}{c}* *-0,11 \\
(0,05)\end{array}$ & $\begin{array}{l}{ }^{* *}-0,01 \\
(0,00)\end{array}$ & $\begin{array}{l}*-0,03 \\
(0,01)\end{array}$ & $\begin{array}{l}{ }^{* *}-0,05 \\
(0,02)\end{array}$ & $\begin{array}{c}0,01 \\
(0,01)\end{array}$ \\
\hline $\begin{array}{l}\text { Suporte ao } \\
\text { Franqueado }\end{array}$ & $\begin{array}{c}0,06 \\
(0,20)\end{array}$ & $\begin{array}{l}* * * \mathbf{0}, \mathbf{3} \\
(0,02)\end{array}$ & $\begin{array}{l}0,00 \\
(0,01)\end{array}$ & $\begin{array}{l}{ }^{* *} \mathbf{0}, \mathbf{0 8} \\
(0,04)\end{array}$ & $\begin{array}{l}0,01 \\
(0,01)\end{array}$ \\
\hline$\Delta \_$Mix Contratual & $\begin{array}{l}* * 2,51 \\
(1,57)\end{array}$ & $\begin{array}{l}* 0,55 \\
(0,25)\end{array}$ & $\begin{array}{l}* 1,35 \\
(0,34)\end{array}$ & $\begin{array}{c}* * 0,63 \\
(0,37)\end{array}$ & $\begin{array}{l}* 0,50 \\
(0,29)\end{array}$ \\
\hline Conversão & $\begin{array}{l}-0,01 \\
(0,01)\end{array}$ & $\begin{array}{l}-0,01 \\
(0,01)\end{array}$ & $\begin{array}{c}0,06 \\
(0,10)\end{array}$ & $\begin{array}{c}* * * 0,02 \\
(0,01)\end{array}$ & $\begin{array}{l}-0,03 \\
(0,04)\end{array}$ \\
\hline$\Delta \_$TXF & $\begin{array}{l}0,06 \\
(2,71)\end{array}$ & $\begin{array}{l}* 0,38 \\
(0,08)\end{array}$ & $\begin{array}{c}{ }^{*}-\mathbf{0 , 5 9} \\
(0,30)\end{array}$ & $\begin{array}{c}0,14 \\
(0,29)\end{array}$ & $\begin{array}{l}* 0,60 \\
(0,29)\end{array}$ \\
\hline$\Delta \_$Royalties & $\begin{array}{c}3,89 \\
(3,39)\end{array}$ & $\begin{array}{l}{ }^{0,23} \\
(0,03)\end{array}$ & $\begin{array}{l}* 0,14 \\
(0,05)\end{array}$ & $\begin{array}{l}-0,07 \\
(0,19)\end{array}$ & $\begin{array}{c}0,01 \\
(0,11)\end{array}$ \\
\hline $\begin{array}{l}\text { Razão Inversa de } \\
\text { Mills }\end{array}$ & $\begin{array}{c}* * *-1,37 \\
(0,78)\end{array}$ & $\begin{array}{c}* * *-0,07 \\
(0,04)\end{array}$ & $\begin{array}{l}-0,09 \\
(0,07)\end{array}$ & $\begin{array}{l}-0,10 \\
(0,11)\end{array}$ & $\begin{array}{l}-0,17 \\
(0,25)\end{array}$ \\
\hline Intercepto & $\begin{array}{c}* * 1,69 \\
(0,95) \\
\end{array}$ & $\begin{array}{l}* 0,07 \\
(0,36) \\
\end{array}$ & $\begin{array}{l}{ }^{*} \mathbf{0 , 3 3} \\
(0,10) \\
\end{array}$ & $\begin{array}{l}* * 0,24 \\
(1,13) \\
\end{array}$ & $\begin{array}{c}0,31 \\
(0,27)\end{array}$ \\
\hline $\mathbf{N}$ & 38 & 71 & 50 & 110 & 107 \\
\hline Estatística F & 2,37 & $2.944,02$ & 4,15 & 2,48 & 2,52 \\
\hline Significância & 0,03 & 0,00 & 0,00 & 0,02 & 0,02 \\
\hline $\mathbf{R}^{2}$-ajustado & 0,36 & 0,87 & 0,63 & 0,27 & 0,08 \\
\hline \multicolumn{6}{|c|}{$\begin{array}{l}\text { * Significante a } 1 \% \\
\text { ** Significante a } 5 \% \\
\text { *** Significante a } 10 \% \\
\text { \# Variáveis não consideradas no modelo do grupo das Redes de Rápido Crescimento em função } \\
\text { do número reduzido de observações. } \\
\text { Variável Dependente: Crescimento } \\
\text { Erro padrão robusto entre parênteses }\end{array}$} \\
\hline
\end{tabular}

Como já mencionado, o problema de heterocedasticidade nos dados foi corrigido pelo erro padrão robusto aplicado tanto na mlogit como das regressões MQO.

Para verificar problemas de multicolinearidade entre variáveis no método MQO aplicou-se a análise de fator de inflação da variância (VIF - do inglês Variance Inflation Factor). A Tabela 25 indica os fatores VIF as variáveis empregadas nas regressões MQO para os cinco grupos. Como evidenciado nos resultados do teste 
FIV, não existem variáveis redundantes na análise proposta (FIV $<10$ para todas as variáveis, em todos os testes).

Tabela 25 - Fatores FIV para multicolinearidade (fonte: elaborado pelo autor)

\begin{tabular}{|c|c|c|c|c|c|}
\hline Variáveis & $\begin{array}{c}\text { Rápido } \\
\text { Crescimento }\end{array}$ & Maduras & $\begin{array}{c}\text { Alto } \\
\text { Investimento }\end{array}$ & $\begin{array}{c}\text { Mais } \\
\text { Franquia }\end{array}$ & Metropolitanas \\
\hline Efeito Automação & 1,10 & 1,20 & 1,47 & 1,09 & 1,33 \\
\hline Densidade & 1,61 & 1,10 & 1,62 & 1,10 & 1,22 \\
\hline Proporção Classe CD & 1,44 & 1,28 & 1,89 & 1,15 & 1,14 \\
\hline Apoios & 2,68 & 1,27 & 1,86 & 1,58 & 1,51 \\
\hline Selo ABF & 1,78 & 1,72 & 2,46 & 1,34 & 1,71 \\
\hline$\Delta \_$Mix Contratual & 1,58 & 2,13 & 1,29 & 1,18 & 1,69 \\
\hline$\Delta \_$TXF & 1,46 & 1,12 & 1,21 & 1,04 & 1,07 \\
\hline$\Delta \_$Royalties & 3,11 & 2,17 & 1,30 & 1,29 & 1,53 \\
\hline Razão Inversa de Mills & 2,26 & 1,21 & 1,91 & 1,20 & 1,62 \\
\hline FIV Médio & 1,89 & 1,47 & 1,67 & 1,22 & 1,42 \\
\hline
\end{tabular}

O grupo das redes de Rápido Crescimento apresenta um número pequeno de observações, comprometendo a capacidade de generalização de seus resultados. Além disso, os resultados do teste indicam não significância do mesmo, invalidando seus resultados. 


\section{DISCUSSÃO DE RESULTADOS}

Nesta seção discutem-se os resultados da análise econométrica sobre os determinantes diferenciais do crescimento da rede entre os grupos identificados desde a análise fatorial.

A razão inversa de Mills se mostrou significante somente no grupo de redes de Rápido Crescimento e redes Maduras. Ou seja, neste grupo existem aspectos não observáveis que gerariam viés nos resultados das regressões, caso não houvesse a presença da razão inversa de Mills. Uma vez que o procedimento foi adotado esta condição deixa de ser um problema. Nos demais grupos tais aspectos não são suficientes para gerar viés de endogeneidade nos dados.

\subsection{Risco na Operação}

O Efeito do Nível de Automação na Loja mostrou-se significante ( $p$ - valor $=$ $0,03)$ em apenas um grupo: o das redes de Alto Investimento. Porém, o sinal obtido é oposto ao esperado. Em outras palavras, o nível de automação medido pela variável não afeta crescimento, de forma que H1a não é suportada.

Considerando que esta variável não é significante em nenhum dos demais grupos da análise, infere-se que não há relação visível entre automação e crescimento. Isso implica que processos mais automatizados, mesmo com consequentes ganhos em padronização e replicação, não explicam crescimento de redes nos grupos identificados na amostra.

Algumas intuições são possíveis. A automação contribui para que a rede mantenha a propriedade sobre uma maior proporção de lojas em função da maior eficiência de monitoramento e menor necessidade de mecanismos verticais de incentivos (BITTI, 2007). Ou seja, a automação eleva a lucratividade de lojas próprias por elevar a eficiência de monitoramento à distância. No entanto, além de não haver esse nível de detalhes nos dados (lucratividades e identificação da propriedade das lojas), não existe qualquer correlação entre a conversão de lojas e nível de automação (Tabela 23). 
Uma vez que maiores níveis de automação aparecem associados a uma maior proporção de lojas próprias (BITTI, 2007), é possível que exista apenas uma relação interveniente entre estas variáveis. Ou seja, o crescimento potencializado pela automação ocorre em redes com uma maior proporção de lojas próprias, caracterizando uma influência da automação sobre o crescimento moderada pelo mix contratual. Esta relação não está captada nestes testes.

Não existem muitos trabalhos empíricos verificando efeitos do nível de automação em redes de franquia. Exceções podem ser vistas em Michael (2000b), o qual verifica o efeito do mix contratual sobre qualidade na ponta e usa a tecnologia de processo como variável de controle para efeitos fixos das redes. Sen (1998) cogita a substituição de trabalho por processos automatizados como forma da rede manter a propriedade sobre mais $\operatorname{lojas}^{40}$. Ou seja, as (poucas) pesquisas identificadas se voltam para o papel da automação como forma de potencializar o monitoramento, aliviando a necessidade de investir em incentivos.

Em suma, não é detectada influência da automação sobre o crescimento, de forma que H1a não é suportada. O fato de a variável apresentar sinal negativo e significante no grupo de redes de Alto Investimento parece captar que, dentre as redes com maior faturamento por loja, crescem aquelas redes que demandam 0 menor investimento do franqueado, o que é relativamente trivial.

Por outro lado, a outra variável relacionada ao construto "Risco na Operação" aparece significante e com sinal esperado em 4 dos 5 grupos estratégicos. O efeito da Densidade aproxima os riscos potenciais do problema de free-riding e somente não é significante no grupo de redes Metropolitanas. Nos casos onde é significante, a variável apresenta o sinal negativo esperado, indicando que o crescimento das redes é beneficiado por certo distanciamento entre as unidades da rede.

Ou seja, quanto menor a densidade de lojas em relação à população total das cidades ocupadas, mais delineado é o mercado subjacente de cada loja, de forma que o operador local terá menos oportunidades de expropriar valor da reputação da marca entregando um nível de esforço aquém do contratado com a rede. Com isso, H1b recebe um considerável suporte.

\footnotetext{
${ }^{40}$ Esse resultado é encontrado em Bitti (2007).
} 
Mesmo no caso das Redes Metropolitanas, para as quais a variável Densidade não se mostrou significante, um racional econômico é possível para explicar o resultado encontrado. Dada a elevada proporção de lojas destas redes em shopping centers, espera-se que a gerência local de cada loja seja submetida a mecanismos de coordenação e controle advindos tanto da própria rede como da administração do shopping center, o que dificulta a realização de ganhos por comportamento oportunista (WARNABY et al., 2005)

Redes Mais Franquia e de Rápido Crescimento apresentam a menor taxa de lojas por cidade entre os grupos (1,99 e 2,40 lojas por cidade ocupada, respectivamente). São também as que apresentam menor população média por cidade. Ou seja, as lojas destas redes têm forte participação em cidades menores, de forma que o território onde atuam tende à exclusividade ${ }^{41}$.

Uma vez que a significância e o sinal negativo se repetem mesmo em redes mais concentradas, conclui-se que os efeitos benéficos de um maior espaçamento entre as lojas se faz sentir sobre o crescimento do número de unidades, independente do grupo do qual a rede faça parte.

Do ponto de vista da validade de construto, um argumento contrário à operacionalização desta variável poderia propor que, na verdade, o que se capta é a mera associação entre crescimento e expansão geográfica. No entanto, se a rede aumentasse o número de lojas de uma forma mais concentrada, haveria aspectos benéficos do efeito escala em monitoramento e logística (por exemplo) decorrentes de uma maior proximidade entre as lojas (SHANE, 1998).

Assim, assumindo racionalidade na gestão das redes, espera-se que o franqueador compare os benefícios entre os ganhos em escala da proximidade com os ganhos de desempenho decorrentes do maior alinhamento de interesses entre a rede e seus franqueados. Ou seja, caso o sinal encontrado fosse positivo, então, os ganhos decorrentes da concentração de lojas superariam os benefícios do alinhamento de interesses no tocante a crescimento da rede.

Além disso, redes maduras posicionadas além do ponto $T_{2}$ na Figura 4 podem já estar dispersas, mas não estarem crescendo. No entanto, mesmo entre redes

\footnotetext{
${ }^{41}$ Isso pode ser declarado contratualmente em relações de franquia, mas esta informação não está disponível para esta pesquisa.
} 
mais maduras, as que mais crescem o fazem de forma dispersa. Portanto, se aceita que a dinâmica de crescimento das redes seja em parte explicada pela menor densidade, uma vez que aspectos de incentivo ao esforço do operador local são potencializados pela menor probabilidade de ocorrência do problema de free-riding.

O aumento da oferta de suporte ao franqueado é positivo e significante em dois grupos de redes: Maduras e Mais Franquia. Em redes maduras, dada sua experiência, espera-se que estas redes consigam desenvolver rotinas operacionais e administrativas transferíveis a franqueados. A transferência destas rotinas é operacionalizada, por exemplo, através de treinamento (MICHAEL, 2000), mas pode ser feita também através dos outros tipos de suporte. Quanto mais suportes ofertados, maior o contato entre a rede e seus franqueados, o que aumenta o grau de supervisão. O sinal positivo deste coeficiente indica tal relacionamento.

De forma similar, também as Redes Mais Franquia apresentam coeficiente positivo e significante para esta variável, interpretando-se que o racional aplicado às redes Maduras também se aplica às Redes Mais Franquia. Em termos de tempo de franquia, Redes Mais Franquia estão entre as mais experientes entre os grupos, somente sendo superadas pelas redes Maduras. Tanto a Tabela $14 \mathrm{com}$ as cargas fatoriais dos grupos, como o Quadro 11 com o resultado do teste de Games-Howell confirmam estatisticamente a diferenciação destas redes em relação às demais para o tempo de franquia.

Esse resultado pode ser comparado a conclusões correlatas verificadas na literatura. Por exemplo, o treinamento de franqueados inexperientes (um dos principais suportes oferecidos aos operadores locais) eleva o nível de dependência destes em relação à rede, elevando seus custos de saída da relação (MICHAEL, 2000a). Este incremento no nível de alinhamento entre as partes está relacionado a maiores taxas de sobrevivência em redes de franquia. Se as redes se beneficiam em atrair franqueados com menos experiência de forma a aumentar seu poder de barganha ex post e, ao mesmo tempo, passam por fase de crescimento através da atração de franqueados, então, terão maior sucesso aquelas que convertem sua experiência em suporte ao franqueado (CASTROGIOVANNI et al., 2006).

Uma explicação aparentemente alternativa da relação entre o aumento no nível de suporte a franqueados e crescimento da rede teria a ver com efeitos de 
reputação. No entanto, se fosse esse o caso, seria esperado que a significância estivesse nas redes de menor experiência, as quais ainda não conseguiram acumular reputação no mesmo nível das redes mais velhas. Além disso, testes alternativos verificando o investimento das redes em certificação junto à $A B F$ não se mostraram significantes na explicação do crescimento em nenhum dos grupos.

Em resumo, o aumento na oferta de suportes ao franqueado em redes de franquia mais experientes explica parte do crescimento destas redes, de forma que H1c é suportada.

\subsection{Balanceamento entre Modalidades de Incentivos}

A primeira variável relacionada a este construto é a variação do mix contratual representada pela variação na proporção franqueada das redes. Esta variável é significante e positiva para todos os grupos. Ou seja, para todas as redes da amostra, o crescimento é, em parte, explicado pelo aumento da proporção franqueada.

Considerando que todos os grupos apresentam tendência de crescimento, mesmo aqueles com redes mais experientes, a predição da TRE de que apenas redes jovens tenderiam a usar franqueados para sustentar seu crescimento parece não receber suporte.

A explicação para esse comportamento pode ser derivado de TA. Em todos os grupos se observa um movimento das redes em direção a cidades menores e/ou menos ricas. Isso é visto no comportamento da variável Mercados Emergentes, a qual aproxima a ocupação deste tipo de cidade pelas redes. Os grupos apresentam números muito parecidos entre si (ente 16\% e 25\%). Segundo a visão clássica de TA, a ocupação destes mercados é sustentada por contratos de franquia ao invés de lojas próprias, tanto pela dificuldade de monitorar operações em mercados distantes e não familiares (RUBIN, 1978) como pelo fato de que franqueados compreendem melhor os mercados locais e suportam a maior parte das despesas envolvidas (WELSH et al., 2006) $)^{42}$.

\footnotetext{
${ }^{42}$ Embora a TRE preveja um uso menor de franquias por redes de maior porte e experiência, ela compartilha com TA a presunção do benefício do conhecimento local de franqueados (COMBS et al., 2011).
} 
Em suma, a variável é positiva e significante em todos os grupos, de forma que $\boldsymbol{H} 2 \mathbf{a}$ é amplamente suportada.

No entanto, além de novas unidades franqueadas suportando o crescimento, verifica-se também se as redes estão convertendo a propriedade das unidades da rede e se isso tem relação com crescimento. Em outras palavras, busca-se entender se as redes estão convertendo unidades próprias em unidades franqueadas (e viceversa) de forma relacionada à evolução de seu porte.

Redes maduras tendem a apresentar uma maior estabilidade no número de lojas. Neste ponto, o padrão cúbico verificado em Castrogiovanni et al. (2006) sobre o mix contratual é mais provável. Isto é, a influência da escassez de recursos típica dos primeiros anos das redes já é menor, de forma que a rede se concentra em gerenciar problemas de coordenação. Com a maturidade, uma maior familiaridade com os mercados ocupados e avanços na tecnologia de monitoramento podem aliviar a necessidade de mecanismos de incentivos, possibilitando mais lojas próprias.

A variável Conversão apresenta significância e sinal negativo (conforme esperado) apenas no grupo de redes Mais Franquia, o que confere certo suporte H2b. A variável não apresentou significância no grupo onde mais se esperava este efeito: redes Maduras. Estas redes são as menos densas em termos de lojas/população e loja/cidade. Portanto, estão menos expostas a problemas de freeriding. No entanto, a Conversão não parece ser um subterfúgio popular entra as redes, pelo menos no que diz respeito ao crescimento.

Uma possível explicação pode ser derivada do comportamento do mix contratual. Como verificado acima, ela se mostra significante para todos os grupos, o que é um indicativo da atração de franqueados para possibilitar oportunidades de crescimento mesmo entre redes maduras, o que poderia ter relação até com o momento de crescimento da economia brasileira e do surgimento de novos mercados em regiões antes desprezadas por estas redes.

Além disso, é possível que o efeito da conversão da propriedade das lojas seja mais sentido sobre a lucratividade das mesmas, o que não é captado pelas variáveis tratadas neste estudo. Em resumo, apesar da significância com sinal esperado em um dos grupos, os resultados desta variável são inconclusivos. 
A variação das taxas fixas de franquia se mostrou significante em três grupos de redes: Maduras, de Alto Investimento e Metropolitanas. No entanto, a variação da taxa de royalties acompanhou a variação das taxas fixas (tanto em significância como no sinal) em apenas dois grupos: Maduras e de Alto Investimento.

No caso das Redes Maduras o sinal das taxas é positivo, confirmando a expectativa teórica mais recente de que as redes elevam ambas as taxas na medida em que acumulam reputação e valor da marca (MURUYAMA; YAMASHITA, 2011; POLO-REDONDO et al., 2011).

Em redes de Alto Investimento o sinal é negativo e aqui parece haver uma relação com o comportamento inesperado da variável Nível de Automação na Loja. Ou seja, do ponto de vista do crescimento no número de unidades, a atratividade de preços parece prevalecer sobre quaisquer outras variáveis. Assim, dentre estas redes, crescem aquelas que demandam o menor investimento de franqueados.

Em redes Metropolitanas, apenas a variação da taxa fixa de franquia mostrou significância, além do sinal esperado. A variação na taxa de royalties não se mostrou significante.

Estas redes possuem aspectos operacionais que justificam estes resultados. Este grupo é composto praticamente por redes do segmento de Alimentação e Vestuário. O motivo da não significância da variação da taxa de royalties pode ter relação com o que é verificado em Vasquez (2005), o qual identifica que uma parte substancial dos royalties está embutida nos preços dos insumos fornecidos pelo franqueador. Esse racional é válido principalmente para redes de Vestuário, as quais transacionam produtos acabados muitas vezes fabricados pelo próprio franqueador. Assim, o valor de royalties informado no anuário e usado para operacionalizar a variável não conseguiria captar o real montante de royalties cobrados.

No entanto, a taxa fixa de franquia é positiva e significante, como esperado. A relação do grupo com o setor de shopping centers está na base da explicação. Centros comerciais conseguem gerar uma demanda concentrada através do fluxo de pessoas atraídas pelas lojas âncora (CARTER; VANDELL, 2005). Assim, ante a perspectiva de boas vendas, a rede consegue elevar as taxas praticadas.

Esse quadro também poderia auxiliar a explicação da não significância da taxa de royalties. É possível que as redes associadas a este grupo concentrem sua 
remuneração na taxa fixa por questões de incentivos. Lojas estabelecidas em shopping centers precisam pagar uma série de taxas condominiais, alugueis e luvas, de forma que uma parte substancial do resíduo destinado ao franqueado é consumida. Operar com royalties mais baixos poderia aliviar franqueados neste sentido. De qualquer forma, os dados disponíveis não permitem uma conclusão mais objetiva a respeito.

A não significância da variação das taxas nas jovens redes de Rápido Crescimento já era esperada em função do momento do ciclo de vida em que estão. Com o tempo, na medida em que o ritmo de crescimento diminua, as redes passem a arbitrar taxas maiores para refletir reputação e força da marca.

Com relação às redes Mais Franquia, considerando serem as com maior proporção franqueada e maior presença nos chamados mercados emergentes, é possível que elas estejam incapacitadas de elevarem taxas em um momento que buscam manter a expansão. Ou seja, por estarem em regiões mais pobres, a elevação destas taxas inviabilizaria a operação por parte de franqueados potenciais. Considerando que estes contratos são, por força de lei, homogêneos em sua oferta, tal quadro dificultaria alterações nas taxas.

Alternativamente, o fato de que estas taxas não são significantes nestas redes parece confirmar que ainda falta a elas reputação e valor de marca o suficiente para manter as taxas em elevação mesmo em períodos de crescimento.

No entanto, o resultado agregados dos testes indica, em suma, que H2c e $\boldsymbol{H} \mathbf{2 d}$ recebem considerável (mas não inequívoco) suporte na análise.

\subsection{Síntese da Análise}

O Quadro 12 resume as características dos grupos, bem como as variáveis determinantes do crescimento em cada grupo. 
Quadro 12 - Resumo da descrição dos grupos com os determinantes do crescimento das redes vinculadas (fonte: elaborado pelo autor)

\begin{tabular}{|c|c|c|}
\hline Grupos & Características & Determinantes do Crescimento \\
\hline $\begin{array}{l}\text { Grupo } 1 \text { - Redes de Rápido } \\
\text { Crescimento }\end{array}$ & $\begin{array}{l}\text { Simultaneamente, são as maiores e mais jovens redes entre os grupos. } \\
\text { Elevada taxa média anual de abertura de novas lojas. } \\
\text { Elevada taxa média anual de abertura de novas franquias. } \\
\text { Grande dispersão geográfica. } \\
\text { São as redes que mais cresceram no período analisado. } \\
\text { Grande presença em cidades pequenas e capitais de estados fora do eixo } \\
\text { RJ-SP. } \\
\text { Baixo investimento necessário pelo franqueado. } \\
\text { Opera com lojas de rua com pouca metragem e poucos funcionários. }\end{array}$ & $\begin{array}{l}\text { Baixa densidade de lojas mitiga o incentivo ao } \\
\text { comportamento oportunista (free-riding), elevando o } \\
\text { alinhamento de interesses e o desempenho loja a } \\
\text { loja. } \\
\text { Variação da proporção franqueada: o modelo de } \\
\text { negócios é fundamentado na atração de } \\
\text { franqueados. }\end{array}$ \\
\hline Grupo 2 - Redes Maduras & $\begin{array}{l}\text { São os mais experientes franqueadores entre os grupos. } \\
\text { São também grandes e dispersos em relação à amostra. } \\
\text { Apresentam grande concentração de lojas em relação ao número de } \\
\text { cidades e à população das cidades ocupadas. } \\
\text { São as redes menos presentes em capitais de estados. } \\
\text { São as redes que menos cresceram no período analisado. } \\
\text { São as redes que mais têm convertido lojas franqueadas para lojas } \\
\text { próprias. }\end{array}$ & $\begin{array}{l}\text { Baixa densidade de lojas mitiga o incentivo ao } \\
\text { comportamento oportunista (free-riding), elevando o } \\
\text { alinhamento de interesses e o desempenho loja a } \\
\text { loja. } \\
\text { Suporte ao franqueado como forma de estabelecer } \\
\text { maior controle downstream na rede. } \\
\text { Variação da proporção franqueada: o modelo de } \\
\text { negócios é fundamentado na atração de } \\
\text { franqueados. } \\
\text { Variação na taxa fixa de franquia. } \\
\text { Variação na taxa de royalties. }\end{array}$ \\
\hline
\end{tabular}




\begin{tabular}{|c|c|c|}
\hline Grupos & Características & Determinantes do Crescimento \\
\hline $\begin{array}{l}\text { Grupo } 3 \text { - Redes de Alto } \\
\text { Investimento }\end{array}$ & $\begin{array}{l}\text { São as redes que demandam maior nível de investimento de franqueados. } \\
\text { Tipicamente são lojas grandes em área e faturamento, com operações mais } \\
\text { complexas e grande número de funcionários. } \\
\text { A maioria das redes estrangeiras operando no Brasil está neste grupo. } \\
\text { Estão concentradas em cidades grandes e mais ricas. }\end{array}$ & $\begin{array}{l}\text { Redes com menor nível de investimento demandado } \\
\text { ao franqueado crescem mais, incluindo taxas fixas e } \\
\text { variáveis de franquia. } \\
\text { Baixa densidade de lojas mitiga o incentivo ao } \\
\text { comportamento oportunista (free-riding), elevando o } \\
\text { alinhamento de interesses e o desempenho loja a } \\
\text { loja. } \\
\begin{array}{l}\text { Variação da proporção franqueada: o modelo de } \\
\text { negócios é fundamentado na atração de } \\
\text { franqueados }\end{array}\end{array}$ \\
\hline $\begin{array}{l}\text { Grupo } 4 \text { - Redes Mais } \\
\text { Franquia }\end{array}$ & $\begin{array}{l}\text { São franqueadores relativamente experientes com forte presença em } \\
\text { cidades menores e mais pobres. } \\
\text { São as redes que menos tempo operaram na forma verticalmente integrada. } \\
\text { São as redes com maior proporção franqueada. } \\
\text { São as redes com menor densidade de lojas da amostra. } \\
\text { São as redes que mais têm convertido lojas próprias em franqueadas. }\end{array}$ & $\begin{array}{l}\text { Baixa densidade de lojas mitiga o incentivo ao } \\
\text { comportamento oportunista (free-riding), elevando o } \\
\text { alinhamento de interesses e o desempenho loja a } \\
\text { loja. } \\
\text { Suporte ao franqueado como forma de estabelecer } \\
\text { maior controle downstream na rede. } \\
\text { Variação da proporção franqueada: o modelo de } \\
\text { negócios é fundamentado na atração de } \\
\text { franqueados. } \\
\text { As redes que mais crescem são aquelas que têm } \\
\text { convertido lojas franqueadas em lojas próprias. }\end{array}$ \\
\hline $\begin{array}{l}\text { Grupo } 5 \text { - Redes } \\
\text { Metropolitanas }\end{array}$ & $\begin{array}{l}\text { Redes vinculadas ao setor de shopping center, o que da forma a todo seu } \\
\text { perfil operacional ()tamanho de loja, prazo de contrato, etc.). } \\
\text { O grupo é composto basicamente por redes dos setores de Alimentação e } \\
\text { Vestuário. } \\
\text { São as menores redes da amostra em número de lojas e as menos } \\
\text { franqueadas. }\end{array}$ & $\begin{array}{l}\text { Variação da proporção franqueada: o modelo de } \\
\text { negócios é fundamentado na atração de } \\
\text { franqueados. } \\
\text { Variação na taxa fixa de franquia. } \\
\text { Crescimento do setor de shopping centers no Brasil. }\end{array}$ \\
\hline
\end{tabular}




\section{CONCLUSÕES}

Este trabalho analisou empírica e conceitualmente alguns dos determinantes do crescimento de redes de franquia. Em uma amostra de 376 redes associadas à $A B F$, foram aplicadas análises multivariadas e econométricas visando aumentar o entendimento a respeito da dinâmica de crescimento das redes.

Em função das acentuadas diferenças entre setores e redes, optou-se inicialmente por segregar as redes em grupos distintos. Para isso, buscou-se na literatura de ciclo de vida e grupos estratégicos referências teóricas e metodológicas. Com isso foi possível trazer para o contexto brasileiro a discussão sobre grupos estratégicos em redes de franquia, a qual já conta com trabalhos em mercados como o Canadá (CARNEY; GEDAJLOVIC, 1991), EUA (MARTINEZ-TORRES; TORAL-MARIN, 2010) e Espanha (CATALUÑA et al., 2007).

Através de análise fatorial, cinco grupos de redes foram identificados com base em atributos que expressam o comportamento estratégico de cada grupo. Tais atributos decorrentes de um processo histórico de interação entre as redes e as forças de mercado ao longo do tempo, o qual é denominado como ciclo de vida. Ou seja, o conceito de estratégia aqui aplicado se refere às escolhas feitas pelas redes ao longo do caminho percorrido em seu ciclo de vida (path dependence).

Investimentos específicos em ativos tangíveis e intangíveis, físicos e humanos são demandados nessa trajetória. Quanto maior a especificidade destes ativos, maiores os custos de mudança, de forma que há pouca mobilidade entre os grupos. Aspectos como a política de taxas praticadas, nível de tecnologia de produção, mecanismos de controle e monitoramento empregados, entre outros, decorrem diretamente do perfil estratégico das redes e dos grupos.

Uma vez identificados os grupos, passou-se à etapa de análise do crescimento destas redes. Com base em um período de três anos (2009-2011, ou seja, após os distúrbios de 2008), aplicou-se uma análise econométrica sobre as 376 redes nos 5 grupos identificados. Dois construtos derivados da teoria da agência, economia dos custos de transação e teoria dos recursos escassos são confrontados a uma medida de crescimento das redes. 
Controlando para problemas de endogeneidade nos dados, os resultados indicam que os o aumento da proporção franqueada está associada ao crescimento nos cinco grupos. No entanto, um dos grupos indicou que a conversão de lojas franqueadas em lojas próprias está associada ao crescimento da rede.

Além disso, redes maduras com maior capital reputacional acumulado estão conseguindo elevar as taxas fixas e variáveis mesmo atraindo novos franqueados, ao contrário daquelas redes cujo montante de investimento demandado de franqueados é maior.

Outro aspecto relacionado ao crescimento em quase todas as redes é a maior dificuldade de franqueados expropriarem valor da marca através de comportamentos indesejados como o free-riding. O único grupo onde a variável empregada para captar este efeito não se mostrou significante foi o de redes com grande vinculação a shopping centers. A interpretação disso é que o próprio centro comercial monitora o desempenho do lojista, dificultando a ação oportunista.

Com relação ao controle de franqueados, as redes mais maduras crescem investindo em mecanismos de controle na forma de suporte aos agentes locais. No entanto, a proxy usada para captar efeitos do nível de automação não se mostrou significante (ou adequada).

Espera-se que a pesquisa tenha colaborado ao abordar um aspecto negligenciado pela literatura em franchising (nacional e estrangeira): a relação entre franquias e shopping centers. A relação entre custos de mudança decorrente de ativos específicos não é recorrente na literatura nacional [embora Farina (1999) seja uma exceção]. Por fim, o trabalho contribui com a discussão sobre grupos estratégicos entre redes de franquia no Brasil.

\subsection{Limitações da Pesquisa}

Pesquisas como esta, ancoradas em dados secundários, permitem um maior grau de generalização e servem como orientação para estudos mais customizados e aderentes à realidade do mercado.

No entanto, não se pode deixar de apontar certa fragilidade na qualidade da informação usada. Como mencionado, em alguns casos, aspectos da construção 
das variáveis precisaram ser desconsiderados por falta de dados. Um exemplo disso é a operacionalização da variável "Densidade" (Seção 5.6.2.1), a qual foi simplificada assumindo-se que, em caso de grande concentração de lojas de uma mesma rede em uma área menor, haveria maior probabilidade de ocorrência do problema de free-riding.

Muitas das variáveis disponibilizadas no Guia Oficial de Franquias da ABF representam médias ou faixas de mínimo-máximo de valores. Se, por um lado, isso não chega a inviabilizar o estudo (fontes como essa são recorrentes em inúmeros trabalhos relacionados ao tema), por outro, certa parcimônia deve ser estabelecida na interpretação dos resultados.

Além disso, o horizonte de tempo avaliado é relativamente curto; e resulta de um trade-off : caso se optasse por um período de tempo maior, o número de redes cairia demasiadamente. Assim, grupos como o de redes de Rápido Crescimento e de Alto investimento ficariam ainda menores, inviabilizando a análise de grupos estratégicos.

Frisa-se por fim que a metodologia aqui empregada em termos de coleta de dados é recorrentemente aplicada em estudos correlatos publicados em periódicos indexados nacionais e internacionais. Tanto a publicação cientifica com esse tipo de dados como a natureza pública destas informações legitimam seu emprego nesta pesquisa.

\subsection{Sugestão de Pesquisas Futuras}

Algumas das fragilidades acima mencionadas são por si oportunidades de pesquisas relacionadas. Por exemplo, partindo da distinção entre grupos estratégicos, estudos de caso ambientados em redes específicas de um dos grupos permitiriam coletar informações mais fidedignas quanto à tecnologia de monitoramento (ou automação) e o impacto disso no desempenho agregado da rede.

A estimação do efeito da variável "Densidade" poderia ser sofisticada, aumentando seu escopo conforma esquematizado na Figura 6. Além disso, uma 
comparação desse efeito cláusulas contratuais de concessão de territórios exclusivos a franqueados constituiria um controle conveniente para a variável.

Três importantes aspectos de firmas franqueadas não mencionados nesta pesquisa têm a ver com o nível de informalidade como motivador do risco moral de franqueados, a internacionalização de redes brasileiras e com o uso de contratos de máster-franquia ${ }^{43}$. Os temas apresentam excelentes oportunidades de pesquisa futuras, mas demandam a condução de pesquisas de campo e/ou estudos de caso. Dados secundários como os aqui aplicados não são suficientes para este nível de profundidade.

Como oportunidade imediata de pesquisa, caberia a análise daquelas redes situadas nas margens de seus grupos. Ou seja, redes cujo perfil estratégico se mostra difuso. De acordo com o estudo aqui desenvolvido, espera-se que estas redes apresentem resultados piores em termos de crescimento, faturamento, lucratividades, dentre outros. No entanto, uma nova investigação é necessária sabendo-se de antemão que dados secundários não são suficientes para tal pesquisa.

Alguns movimentos recentes observados no setor de franquia no Brasil parecem constituir uma oportunidade de contribuição cientifica entre o médio e o longo prazo. Estão se tornando comuns políticas de gestão de redes de franquia voltadas para a valorização rápida e posterior venda a holdings, asset managements. Algumas aquisições têm sido noticiadas ao público em geral como a recente aquisição da rede Yázigi (a mais antiga rede franqueada do Brasil) pelo grupo Multi (dono de outras redes do setor de instrução e treinamento).

Também são vistos os primeiros IPO's (oferta inicial pública de ações) no setor de franquias, como ocorreu recentemente com a rede de calçados Arezzo. Considerando a complexidade na relação da rede com agentes autônomos contratados (como é o caso de franqueados), constitui uma desafiadora oportunidade de pesquisa observar ações para aumento de valor da empresa como meta estabelecida de venda futura.

\footnotetext{
${ }^{43}$ Contratos de máster-franquia são aqueles onde o franqueado é proprietário de mais de uma loja.
} 
Por fim, esta pesquisa analisa o arranjo de franquias exclusivamente pelo lado da oferta, ou seja, a ótica do franqueador. Uma oportunidade de pesquisa que surge em perspectiva é o lado da demanda: o franqueado. Pesquisas coletando dados diretamente de franqueados auxiliariam no entendimento de relações de franquia por captar in loco aspectos tais como o perfil do franqueado, o nível de controle percebido, compliance, etc. 


\section{REFERÊNCIAS}

ASSOCIAÇÃO BRASILEIRA DE SHOPPING CENTERS - ABRASCE. Disponível em: <www.abrasce.com.br>. Acesso em: 23 Janeiro 2012.

AGUIAR, A. Orientação temporal dos gestores: potenciais dimensões e significados. Revista Universo Contábil, v. 7, n. 4, p. 6-21, 2011.

ALCHIAN, A. DEMSETZ, H. Production, Information Costs, and Economic Organization. The American Economic Review, v. 62, n. 5, p. 777-795, 1972.

AQUINO, A. Economia dos arranjos híbridos: o caso da coordenação de serviços em uma usina siderúrgica. Tese (Doutorado em Ciências Contábeis) Faculdade de Economia, Administração e Contabilidade da Universidade de São Paulo, São Paulo, 2005.

AKERLOF, G. The market for "lemons": Quality uncertainty and the market mechanism. The Quarterly Journal of Economics, v. 84, n. 3, p. 488-500, 1970.

ANDERSON, E. W.; MITTAL, V. Strengthening the satisfaction-profit chain. Journal of Service Research, v. 3, n. 2, p.107-120, 2000.

AOKI, M. Toward a comparative institutional analysis. MIT Press, 2001.

ARGOTE, L.; BECKMAN, S.; EPPLE, D. The persistence and transfer of learning in industrial settings. Management Science, v. 36, n. 2, p. 140-154, 1990.

ARRUÑADA, B.; GARICANO, L.; VÁSQUEZ, L. Contractual allocation of decision rights and incentives: the case of automobile distribution. The Journal of Law, Economics, and Organization, v. 17, n. 1, 2001.

ARRUÑADA, B.; VÁSQUEZ, L.; ZANARONE, G. Completing contracts ex post how car manufacturers manage car dealers. Review of Law and Economics, v. 1, n. 1, 2005.

ARRUÑADA, B.; GARICANO, L.; VÁSQUEZ, L. Institutional constraints on organizations: the case of Spanish car dealerships. Managerial and Decision Economics, v. 30, p. 15-56, 2009.

ASSOCIAÇÃO BRASILEIRA DE FRANCHISING (ABF). Guia Oficial de Franquias 2009. São Paulo: Ed. Empreendedor, ano 11, n. 11, 2009.

ASSOCIAÇÃO BRASILEIRA DE FRANCHISING (ABF). Guia Oficial de Franquias 2009. São Paulo: Ed. Empreendedor, ano 12, n. 12, 2010.

ASSOCIAÇÃO BRASILEIRA DE FRANCHISING (ABF). Guia Oficial de Franquias 2009. São Paulo: Ed. Empreendedor, ano 13, n. 13, 2011.

AZOULAY, P.; SHANE, S. Entrepreneurs, Contracts, and the Failure of Young Firms. Management Science, v. 47, n. 3, p. 337-358, 2001. 
BAIMAN, S.; LARCKER, D.; RAJAN, M. Organizational design for business units. Journal of Accounting Research, v. 33, n. 2, p. 205-229, 1995.

BARTHÉLEMY, J. Opportunism, knowledge, and the performance of franchise chains. Strategic Management Journal, v. 29, p. 1451-1463, 2008.

BARTHÉLEMY, J. Agency and institutional influences on franchising decisions. Journal of Business Venturing, v. 26, p. 93-103, 2011.

BARZEL, Y. Measurement cost and the organization of markets. Journal of Law and Economics, v. 25, n. 1, p. 27-48, 1982. Press, 1997.

BARZEL, Y. Economic Analysis of Property Rights. Cambridge University

BARZEL, Y. Economic analysis of property rights. Journal of Institutional and Theoretical Economics, v. 161, n. 3, p. 357-373, 2005.

BHATTACHARYYA, S.; LAFONTAINE, F. Double-sided moral hazard and the nature of share contracts. The RAND Journal of Economics, v. 26, n. 4, p. 761-781, 1995.

BEALES, J. H.; MURIS, T. J. The foundations of franchise regulation: issues and evidence. Journal of Corporate Finance, v. 2, p. 157-197, 1995.

BITTI, E. Efeitos da dispersão geográfica de lojas em redes de franquia do Brasil. Vitória: FUCAPE 2007. Dissertação (Mestrado) - Programa de PósGraduação em Ciências Contábeis da Fundação Instituto de Pesquisas em Contabilidade, Economia e Finanças, Vitória, 2007.

BLUT, M.; BACKHAUS, C.; HEUSSLER, T.; WOISETSCHLÄGER, D.; EVANSCHITZKY, H.; AHLERT, D. What to Expect After the Honeymoon: Testing a Lifecycle Theory of Franchise Relationships. Journal of Retailing, v. 87, n. 3, p. 306-319, 2011.

BOOTH, W. C.; COLOMB, G. G.; WILLIAMS, J. M. The craft of research. The University of Chicago Press. 1995.

BORDONABA-JUSTE, V.; LUCIA-PALACIOS, L.; POLO-REDONDO, Y. Influence of franchisors' competitive strategies on network size: the impact of entry timing decision. Journal of Marketing Channels, v. 17, n. 1, p. 33-49, 2010.

BOULAY, J. The role of contract, information systems and norms in the governance of franchise systems. International Journal of Retail \& Distribution Management, v. 38, n. 9, p. 662-676, 2010.

BRADACH, J.; ECCLES, R. Price, Authority, and Trust: From Ideal Types to Plural Forms. Annual Review of Sociology, v. 15, p. 97-118, 1989.

BRADACH, J. Using the plural form in the management of restaurant chains. Administrative Science Quarterly, v. 42, p. 276-303, 1997. 
BRICKLEY, J. A.; DARK, F. H. The choice of organizational form: the case of franchising. Journal of Financial Economics, v. 18, n. 2, p. 401-420, 1987.

BRICKLEY, J. A.; DARK, F. H. WEISBACH, M. S. The economic effects of franchise termination laws. Journal of Law and Economics, v. 34, n. 1, 1991.

BRICKLEY, J. A. Incentive conflicts and contractual restraints: Evidence from franchising. Journal of Law and Economics, v. 42, n. 2, 1999.

BRICKLEY, J. A. Royalty Rates and Upfront Fees in Share Contracts: Evidence from franchising. Journal of Law, Economics, and Organization, v. 18, n. 2, p. 511-535, 2002.

BRICKLEY, J. A.; MISRA, S. H.; LAWRENCE, V. H. Contract duration: evidence from franchising. Journal of Law and Economics, v. 49, n. 1, p. 173-196, 2006.

BROUSSEAU, E.; GLACHANT, J. New institution economics: a guidebook. Cambridge University Press, 2008.

BROWN Jr., W. Transaction costs, corporate hierarchies, and the theory of franchising. Journal of Economic Behavior \& Organization, v.36, n. 3, p. 319-329, 1998.

BROWNELL, P.; MERCHANT, K. A. The budgetary and performance influences of product standardization and manufacturing process automation. Journal of Accounting Research, v. 28, n. 2, p. 388-397, 1990.

CAMPBELL, D.; DATAR, S.; SANDINO, T. Organizational Design and Control across Multiple Markets: The Case of Franchising in the Convenience Store Industry. The Accounting Review, v. 84, n. 6, p. 1749-1779, 2009.

CARTER, C.; VANDELL, K. Stores location in shopping center: theory and estimates. Journal of Real Estate Research, v. 27, n. 3, p. 237-265, 2005.

CASTROGIOVANNI, G.; JUSTIS, R. Strategic and Contextual Influences on Firm Growth: An Empirical Study of Franchisors. Journal of Small Business Management, v. 40, n. 2, p. 98-108, 2002.

CASTROGIOVANNI, G.; COMBS, J.; JUSTIS, R. Resource Scarcity and Agency Theory Predictions Concerning the Continued Use of Franchising in Multioutlet Networks. Journal of Small Business Management, v. 44, n. 1, p. 27-44, 2006.

CATAlUÑA, F.; GARCÍA, A.; CASTRO, E. Proposing new variables for the identification of strategic groups in franchising. International Entrepreneurship and Management Journal, v. 3, n. 4, p. 355-377, 2007.

CAVES, R.; MURPHY, W. Franchising: firms, markets, and intangible assets. Southern Economic Journal, v. 42, n. 4, p. 572-586, 1976. 
CAVES, R.; PORTER, M. From entry barriers to mobility barriers: Conjectural decisions and contrived deterrence to new competition. Quarterly Journal of Economics, v. 91, p. 241-261, 1977.

CHABOWSKI, B.; HULT, T.; MENA, J. The retailing literature as a basis for franchising research: using intellectual structure to advance theory. Journal of Retailing, v. 87, n. 3, p. 269-284, 2011.

CHASE, R. The customer contact model for organization design. Management Science, v. 29, n. 9, p. 1037-1050, 1983.

CHAUDEY, M.; FADAIRO, M. Contractual Design as a Determinant of Performance: Evidence from Franchising. International Journal of the Economics of Business, v. 15, n. 1, p. 117-127, 2008.

CHERTO, M.; CAMPORA, F.; GARCIA, F.; RIBEIRO, A.; IMPERATORE, L. Franchising: uma estratégia para expansão dos negócios. São Paulo: Premier Máxima, 2006.

CLIQUET, G. Plural forms in store networks: A model for store network evolution. The International Review of Retail, Distribution and Consumer Research, v. 10, n. 4, p. 369-378, 2000.

COASE, R. The nature of the firm. Economica, v. 4, p. 386-405, 1937.

COMBS, J. G.; KETCHEN Jr., D. J. Can capital scarcity help agency theory explain franchising? revisiting the capital scarcity hypothesis. Academy of Management Journal, v. 42, n. 2, 1999.

COMBS, J. G.; KETCHEN Jr., D. J. Why do firms use franchising as an entrepreneurial strategy?: a meta-analysis. Journal of Management, v. 29, n. 3, p. 443-465, 2003.

COMBS, J. G.; MICHAEL, S.; CASTROGIOVANNI, G. Franchising: a review and avenues to greater theoretical diversity. Journal of Management, v. 30, p. 907931, 2004a.

COMBS, J. G.; KETCHEN, JR., D.; HOOVER, V. A strategic groups approach to the franchising-performance relationship. Journal of Business Venturing, $v, 19$, p. 877-897, 2004b.

COMBS, J. G.; KETCHEN, JR., D.; SHOOK, C. L.; SHORT, J.C. Antecedents and Consequences of Franchising: Past Accomplishments and Future Challenges. Journal of Management, v. 37, n. 1, p. 99-126, 2011.

COX, J.; MASON, C. Standardization versus adaptation: geographical pressures to deviate from franchise formats. The Service Industries Journal, v. 27, n. 8, p. 1053-1072, 2007.

DALTON, D.; KESNER, I. Organizational growth: big is beautiful. Journal of Business Strategy, v. 6, n. 1, p. 38-47, 1985. 
DANT, R. P.; GUNDLACH, G. T. The challenge of autonomy and dependence in franchised channels of distribution: analysis and antitrust implications, Journal of Business Venturing, n. 14, p. 35-67, 1999.

DARR, E. D.; ARGOTE, L.; DENNIS, E. The acquisition, transfer, and depreciation of knowledge in service organizations: productivity in franchises. Management Science, v. 41, n. 11, p. 1750-1762, 1995.

DAVIDSON, R.; MACKINNON, J. Econometric Theory and Methods. Oxford University Press, New York, 2004.

DESAI, P.; SRINIVASAN, K. Demand signaling under unobservable effort in franchising: linear and nonlinear price contracts. Management Science, v. 41, n. 10, p. 1608-1623, 1995.

DESAI, P. Advertising fee in business-format franchising. Management Science, v. 43, n. 10, p. 1401-19, 1997.

DNES, A. Hostages, marginal deterrence and franchise contracts. Journal of Corporate Finance, v. 9, p. 317-331, 2003.

EISENHARDT, K. Agency theory: An assessment and review. Academy of Management Review. v. 14, n. 1, p. 57-74, 1989.

FAMA, E. F.; JENSEN, M. C. Separation of ownership and control. Journal of Law and Economics, v. 26, n. 2, p. 301-325, 1983.

FARINA, E. Competitividade e coordenação de sistemas agroindustriais: um ensaio conceitual. Gestão \& Produção, v. 6, n. 3, 1999.

FÁVERO, L.; BELFIORE, P.; SILVA, F.; CHAN, B. Análise de Dados. Rio de Janeiro, Campus-Elsevier, 2009.

FIANI, R. Crescimento econômico e liberdades: a economia política de Douglass North. Economia e Sociedade, v. 11, n. 1, p. 45-62, 2002.

FIELD, A. Descobrindo a estatística utilizando o SPSS. São Paulo: ARTMED, 2009.

FLADMOE-LINDQUIST, K.; JACQUE, L. L. Control modes in international service operations: the propensity to franchise. Management Science, v. 41, n. 7, p. 1238-1249, 1995.

FLINT-HARTLE, S.; BRUIN, A. Franchising success: Insights from real estate brokerage. International Small Business Journal, v. 29, n. 1. p. 58-77, 2010.

FRAZER, L. Causes of disruption to franchise operations. Journal of Business Research, v. 54, p.227-234, 2001.

FURUBOTN, E.; RICHTER, R. Institutions and economic theory: the contribution of the new institutional economics. Michigan Press, 556p, 2000. 
GALLINI, N.; LUTZ, N. Dual Distribution and Royalty Fees in Franchising. Journal of Law, Economics and Organization, v. 8, n. 3, p. 471-501, 1992.

GAL-OR, E. Maintaining quality standards in franchise chains. Management Science, v. 41, n. 11, 1995.

GILLIS, W.; COMBS, J. Franchisor strategy and firm performance: Making the most of strategic resource investments. Business Horizons, v. 52, p. 553-661, 2009.

GILLIS, W.; CASTROGIOVANNI, G. The franchising business model: an entrepreneurial growth alternative. International Entrepreneurial Management Journal, v. 8, n. 1, p. 75-98, 2010.

GREIF, A. Cultural beliefs and the organization of society: a historical and theoretical reflection on collectivist and individualist societies. The Journal of Political Economy, v. 102, n. 5, 1994.

GROVER, V.; TENG, J.; FIEDLER, K. Investigating the role of IT in building buyer-supplier relationships. Journal of the Association for Information Systems, v. 3, n. 2, p. 217-245, 2002. 2006.

GUJARATI, D. N. Econometria Básica. Campus-Elsevier, Rio de Janeiro,

HACKETT, D. W. The international expansion of U.S. franchise systems: status and strategies, Journal of International Business Studies, v. 7, n. 1, p. 6575, 1976.

HADFIELD G. K. Credible spatial preemption through franchising. The RAND Journal of Economics. v. 22, n. 4, 1991.

HAIR, J.; ANDERSON, R.; TATHAN, R.; BLACK, W. Análise Multivariada de Dados. Porto Alegre: Bookman, 2006.

HAMILTON, B.; NICKERSON, J. Correcting for endogeneity in strategic management research. Strategic Organization, v. 1, n. 1, p. 51-78, 2003.

HART, O.; MOORE, J. Property rights and the nature of the firm. The Journal of Political Economy, n.98, n. 6, 1990.

HECKMAN, J. Shadow prices, market wages, and labor supply. Econometrica, v. 42, n. 4, p. 679-694, 1974.

HECKMAN, J. The common structure of statistical models of truncation, sample selection and limited dependent variables and a simple estimator for such models. Annals of Economic and Social Measurement, v. 5, n. 4, 1976.

HECKMAN, J. Sample Selection Bias as a Specification Error. Econometrica, v. 47, n. 1, p. 153-161, 1979. 
HENNESSY, D. Property rights, productivity, and the nature of noncontractible actions in a franchise system. Journal of Economic Behavior \& Organization, v. 52, n. 4, p. 443-468, 2003.

HUANG, Z. Bargaining, risk and franchising coordination. Computers \& Operations Research, v. 24, n. 1, p. 73-83, 1997.

HUNT, S. D. The trend toward company-operated units in franchise chains. Journal of Retailing, v. 49, n. 2, p. 3-12, 1973.

IPEADATA. Instituto de Pesquisa Econômica Aplicada. Disponível em : http://www.ipeadata.gov.br/ipeaweb.dll/ipeadata?364176703 . Acesso: 10/01/2012

JENSEN, M.; MECKLING, W. Theory of the firm: managerial behavior, agency costs and ownership structure. Journal of Financial Economics, v. 3, n. 4, 1976.

JINDAL, R. Reducing the size of internal hierarchy: the case of multi-unit franchising. Journal of Retailing, v. 87, n. 4, p. 549-62, 2011.

KAISER, H. Little Jiffy, Mark IV. Educational and Psychology Measurement, v. 34, p. 111-17, 1974.

KATZ, B. Territorial exclusivity in the soft drink industry. The Journal of Industrial Economics, v. 27, n. 1, p. 85-96, 1978.

KAUFMANN, P.; LAFONTAINE, F. Costs of control: The source of economic rents for McDonald's franchisees. Journal of Law and Economics, v. 37, p. 417449, 1994.

KAUFMANN, P.; EROGLU, S. Standardization and adaptation in business format franchising. Journal of Business Venturing, v. 14, n. 1, pp.69-85, 1999.

KALNINS, A.; MAYER, K. J. Franchising, ownership, and experience: a study of pizza restaurant survival. Management Science, v. 50, N. 12, p. 1716-1728, 2004.

KIDWELL, R.; NYGAARD, A. A Strategic Deviance Perspective on the Franchise Form of Organizing. Entrepreneurship Theory and Practice, v. 35, p. 467-482, 2011.

KLEIN, B.; CRAWFORD, R. G.; ALCHIAN, A. A. Vertical integration, appropriable rents, and the competitive contracting process. Journal of Law \& Economics, v. 21, n. 2, p. 297-623, 1978.

KLEIN, B.; SAFT, L. F. The law and economics of franchise tying contracts. Journal of Law and Economics, v. 28, n. 2, p. 345-361, 1985.

KLEIN, B. The economics of franchise contracts. Journal of Corporate Finance, v. 2, n. 1-2, p. 9-37, 1995.

KLEIN, P. G. New institutional economics. In: Bouckaert, Boudewijn e De Geest, Gerrit (eds.), Encyclopedia of Law and Economics, Volume I. The History 
and Methodology of Law and Economics. Cheltenham: Edward Elgar, p. 456-489, 2000.

KRUEGER, A. B. Ownership, agency, and wages: an examination of franchising in the fast food industry. The Quarterly Journal of Economics, v. 106, n. 1, p. 75-101, 1991.

LAFONTAINE, F. Agency theory and franchising: some empirical results. The RAND Journal of Economics, v. 23, n. 2, 1992.

LAFONTAINE, F.; KAUFMANN, P. J. The evolution of ownership patterns in franchise systems. Journal of Retailing, v. 70, n. 2, 1994.

LAFONTAINE, F.; BHATTACHARYYA, S. The role of risk in franchising. Journal of Corporate Finance, v. 2, n. 1-2, p. 39-74, 1995.

LAFONTAINE, F.; SLADE, M. E. Retail contracting and costly monitoring: Theory and evidence. European Economic Review, v. 40, p. 923-932, 1996.

LAFONTAINE, F.; SHAW, K. The dynamics of franchise contracting: evidence from panel data. Journal of Political Economy, v. 107, n. 5, p. 1041-1080, 1999.

LAFONTAINE, F.; SHAW, K. Targeting managerial control: evidence from franchising. The RAND Journal of Economics, v. 3, n. 1, p. 131-150, 2005.

LAFONTAINE, F.; MORTON, F. Markets: state franchise laws, dealer terminations, and the auto crisis. The Journal of Economic Perspectives, v. 24, n. 3, p. 233-250, 2010.

LEE, J.; LEE, K.; RHO, S. An evolutionary perspective on strategic group emergent: A genetic algorithm-based model. Strategic Management Journal, v. 23, p. 727-739, 2002.

LEVINTHAL, D. 1988. A survey of agency models of organization. Journal of Economic Behavior and Organization, v. 9, n. 2, p. 153-185, 1988.

LIEBERMAN, M. B.; MONTGOMERY, D. First-mover advantages. Strategic Management Journal, v. 9, p. 41-58, 1988.

LILLIS, C.; NARAYANA, C.; GILMAN, J. Competitive advantage variation over the lifecycle of a franchise. Journal of Marketing, v. 40, n. 4, p. 77-80, 1976.

LUTZ, N. Ownership rights and incentives in franchising. Journal of Corporate Finance, v. 2, n. 1-2, p. 103-131, 1995.

MACHO-STADLER, I.; PEREZ-CASTRILLO, J. D. Centralized and decentralized contracts in a moral hazard environment. Journal of Industrial Economics, v. 46, n. 4, p. 489-510, 1998.

MANESS, R. Incomplete contracts and the choice between vertical integration and franchising. Journal of Economic Behavior and Organization, v. 31, p. 101115, 1996. 
MARGINSON, D.; MCAULAY, L. Exploring the debate on short-termism: a theoretical and empirical analysis. Strategic Management Journal, v. 29, p. 273292, 2008.

MARINO, M. K.; ZYLBERSZTAJN, D. Implementação de estratégias e governança: estudo de múltiplas firmas de distribuição de defensivos agrícolas no Brasil, ALCANCE, v. 14, n. 1, p. 89-111, 2007.

MARTIN, R. Franchising and risk management. The American Economic Review, v. 78, n. 5, 1988.

MARTINS, G. A.; THEÓPHILO, C. R. Investigação científica para ciências sociais aplicadas. São Paulo: Atlas, 2009.

MASTEN, S. Empirical research in transaction-cost economics: progress, challenges, directions. In Transaction Cost Economics and Beyond, John Groenewegen (ed.), Boston: Kluwer: Academic Publishers, p. 41-64, 1996.

MATHEWSON, G. F.; WINTER, R. A. The economics of franchise contracts, Journal of Law and Economics, v. 28, n. 3, 503-526, 1985.

MCNAMARA, G.; DEEPHOUSE, D.; LUCE, R. Competitive positioning within and across $A$ strategic group structure: the Performance of core, secondary, And solitary firms. Strategic Management Journal, v. 24, n. 2, p. 161-181, 2003.

MENARD, C. The economics of hybrid organizations. Journal of Institutional and Theoretical Economics, v. 160, n. 3, p. 345-376, 2004.

MENDELSOHN, M. The Guide to franchising, $7^{\text {th }}$ edition. London: Thompson Learning, 2004.

MICHAEL, S. To franchise or not to franchise: an analysis of decision rights and organizational form shares. Journal of Business Venturing, v. 11, n. 1, p. 5771, 1996.

MICHAEL, S. Investments to create bargaining power: the case of franchising, Strategic Management Journal, v. 21, n. 4, p. 497-514, 2000 a.

MICHAEL, S. The effect of organizational form on quality: the case of franchising. Journal of Economic Behavior \& Organization, v. 43, p. 295-318, $2000 b$.

MICHAEL, S. First mover advantage through franchising, Journal of Business Venturing, v. 18, n. 1, p. 61-80, 2003.

MICHAEL, S.; COMBS, J. Entrepreneurial failure: the case of franchisees. Journal of Small Business Management, v. 46, n. 1, p. 73-90, 2008.

MILGRON, P.; ROBERTS, J. Economics, organization, and management. Englewood Cliffs, New Jersey: Prentice Hall, 1992. 
MINISTÉRIO DO DESENVOLVIMENTO, DA INDÚSTRIA E DO COMÉRCIO EXTERIOR (MDIC). Cartilha: o que é franquia? 2005. Disponível em: < http://www.abf.com.br/abf.com.br/arquivos/GruposTecnicos.pdf> Acesso em: 10 janeiro 2011.

MINISTÉRIO DO DESENVOLVIMENTO, DA INDÚSTRIA E DO COMÉRCIO EXTERIOR (MDIC). Cartilha: o que é franquia? 2005. Disponível em: <http://www.biblioteca.sebrae.com.br/bds/BDS.nsf/64BE85F38096D5B7032570AB00 4A9D66/\$File> Acesso em: 02 julho 2011.

MARTÍNEZ-TORRES, M.; TORAL-MARÍN, S. Strategic group identification using evolutionary computation. Expert Systems with Applications, v. 37, p. 49484954, 2010.

MARUYAMA, M.; YAMASHITA, Y. Franchise fees and royalties: theory and empirical results. Review of Industrial Organization, v. 40, n. 3, p. 167-189, 2011.

MINTZBERG, H.; AHLSTRAND, B.; LAMPEL, J. Safári de estratégia: um roteiro pela selva do planejamento. Porto Alegre: Bookman, 2000.

NATH, D.; GRUCA, T. Convergence across alternative methods for forming strategic groups. Strategic Management Journal, v. 18, p. 745-760, 1997.

NORTH, D. Institutions, institutional change and economic performance. Cambridge: Cambridge University Press, 1990.

NORTH, D. Institutions. The Journal of Economic Perspectives, v. 5, n. 1, 1991.

NORTON, S. W. An empirical look at franchising as an organizational form. Journal of Business, v. 61, n. 2, 1988.

NORTON, S. W. Is franchising a capital structure issue? Journal of Corporate Finance, v. 2, p. 75-101, 1995.

OXENFELDT, A.; KELLY, A. Will successful franchise systems ultimately become wholly-owned chains? Journal of Retailing, v. 44, n. 4, p. 69-83, 1969.

PASWAN, A.; WITTMANN, C. Knowledge management and franchise systems. Industrial Marketing Management, v. 38, p. 173-180, 2009.

PÉNARD, T.; RAYNAUD, E., SAUSSIER, S. Dual distribution and royalty rates in franchised chains: An empirical analysis using French data. Journal of Marketing Channels, v. 10, n. 3/4, pp. 5-31, 2003.

PEREIRA-MOLINER, J.; CLAVER-CORTÉS, E.; MOLINA-AZORÍN, F. Strategy and performance in the spanish hotel industry. Cornell Hospitality Quarterly, v. 51, n. 4, p. 513-528. 2010.

PETERAF, M.; SHANLEY, M. Getting to know you: A theory of strategic group identity. Strategic Management Journal, v. 18, p. 165-186. 1997. 
PIZANTI, I.; LERNER, M. Examining control and autonomy in the franchisorfranchisee relationship. International Small Business Journal, v. 21, n. 2, p. 131159, 1996

POLO-REDONDO, Y.; BORDONABA-JUSTE, V.; LUCIA-PALACIOS, L. Determinants of firm size in the franchise distribution system: Empirical evidence from the Spanish market. European Journal of Marketing, v. 45, n.1/2, p. 170-190, 2011.

PORTER, M. The structures within industries and companies' performance. Review of Economics and Statistics, v. 61, pp. 214-227, 1979.

PORTER, M. E. Estratégia Competitiva - técnicas para análises de indústrias e da concorrência. Rio de Janeiro: Campus, 1986.

PRESCOTT, E.; VISSCHER, M. Organization Capital. Journal of Political Economy, v. 88, n. 3, p. 446-461, 1980.

PRICE, R. Voluntary earnings disclosures in uniform franchise offering circulars. Journal of Accounting and Economics, v. 28, p. 391-423, 2000.

$\mathrm{ROH}, \mathrm{Y}$. Size, growth and risk sharing as the determinants of propensity to franchise in chain restaurants. International Journal of Hospitality Management, v. 21, n. 1, p. 43-56, 2002.

RUBIN, P. The theory of the firm and the structure of the franchise contract. Journal of Law \& Economics, v. 21, n. 1, p. 223-233, 1978.

SEN, K. The use of initial fees and royalties in business-format franchising. Managerial and Decision Economics, v. 14, p. 175-190, 1993.

SEN, K. The use of franchising as a growth strategy by US restaurant franchisors. Journal of Consumer Marketing, v. 15, n. 4, p. 397-407, 1998.

SAMPSON, R. The cost of misaligned governance in R\&D alliances. The Journal of law, Economic, and Organizations, v. 20, n. 2, 2004.

SÁNCHEZ-GÓMEZ, R.; SUÁREZ-GONZÁLEZ, I.; VÁZQUEZ-SUÁREZ, L. EI diseño contractual de la relación de franquicia. Universia Business Review, v. 19, p. $60-83,2008$.

SEWELL, G.; WILKINSON, B. Someone to watch over me: surveillance, discipline and the just-in-time labour process., Sociology, v. 26, n. 2, p. 271-289, 1992.

SHANE, S. Hybrid organizational arrangements and their implications for firm growth and survival: a study of new franchisors. Academic Management Journal. v. 39, p. 216-234, 1996.

SHANE, S. Making new franchise systems work. Strategic Management Journal, v. 19, n. 7, p. 697-707, 1998. 
SHANE, S.; SPELL, C. Factors for new franchise success. MIT Sloan Management Review, v. 39, n. 3, p. 43-50, 1998.

SHANE, S.; FOO, M. New firm survival: institutional explanations for new franchisor mortality. Management Science, v. 45, n. 2, p. 142-159, 1999.

SHANE, S.; SHANKAR, V.; ARAVINDAKSHAN, A. The effects of new franchisor partnering strategies on franchise system size. Management Science, v. 52, n. 5, p. 773-787, 2006.

SHERER, P.; LEE; K. Institutional change in large law firms: A resource dependency and institutional perspective. Academy of Management Journal, v. 45, n. 1, p. 102-119, 2002.

SIA, S.; TANG, M.; SOH, C.; BOH, W. F. ERP systems as a technology of power: empowerment or panoptic control. Database for Advances in Information Systems, v. 33, n. 1, p. 23-37, 2002.

SILVA, V. L. S. Ambiente institucional e organização de redes de franquias: uma comparação entre Brasil e França. Programa de Pós-Graduação em Engenharia de Produção da Universidade Federal de São Carlos. (Tese de Doutorado). São Carlos, 2004, 203f.

SIMON, H. Administrative Behaviour, New York: Macmillan, 1961.

SORENSON, O.; SøRENSEN, J. B. Finding the right mix: franchising, organisational learning and chain performance. Strategic Management Journal, v. 22, p.713-724, 2001.

STORHOLM, G.; SCHEUING, E. Ethical Implications of Business Format Franchising. Journal of Business Ethics, v. 13, n. 3, p. 181-188, 1994.

SZULANSKI, G.; JENSEN, R. Growing through copying: The negative consequences of innovation on franchise network growth. Research Policy, v. 37, $\mathrm{n}$. 10, p. 1732-1741, 2008.

THOMPSON, R. The franchise life cycle and the Penrose effect. Journal of Economic Behavior \& Organization, v. 24, n. 2, p.207-218, 1994.

TRACEY, P.; JARVIS, O. Toward a theory of social venture franchising. Entrepreneurship Theory and Practice, v. 31, n. 5, 2007.

TIGRE, P. Inovação e teorias da firma em três paradigmas. Revista de Economia Contemporânea, v. 3, p. 97-110, 1998.

TUUNANEN, M.; HYRSKY, K. Entrepreneurial paradoxes in business format franchising: an empirical survey of Finnish franchisees. International Small Business Journal, v. 19, n. 4, p.47-62, 2001.

VANCE, P. Determinantes e dinâmica do uso de formas plurais em redes de franquias. Programa de Pós-Graduação em Administração da Faculdade de 
Economia, Administração e Contabilidade da Universidade de São Paulo. (Tese de Doutorado) São Paulo, 2010.

VAZQUEZ, L. Up-front franchise fees and ongoing variable payments as substitutes: an agency perspective. Review of Industrial Organization, v. 26, p. 445-60, 2005.

VAZQUEZ, L. Determinants of contract length in franchise contracts. Economics Letters, v. 97, n. 2, p. 145-150, 2007.

VENKATRAMAN, N.; GRANT, J. Construct measurement in organizational strategy research: a critique and proposal. Academy of Management Review, v. 11, n. 1, p. 71-87, 1986.

WARNABY, G.; BENNISON, D.; DAVIES, B. Marketing communications in planned shopping centres: evidence from the UK. International Journal of Retail \& Distribution Management, v. 33, n. 12, p. 893-904, 2005.

WEAVEN, S.; FRAZER, L. Expansion through multiple unit franchising. International Small Business Journal, v. 25, n. 2, p. 173-205, 2007.

WELSH, D.; ALON, I.; FALBE, C. An examination of international retail franchising in emerging markets. Journal of Small Business Management, v. 44, p. 130-149, 2006.

WILLIAMSON, O. The economic institutions of capitalism. New York: The Free Press, 1985.

WILLIAMSON, O. Corporate finance and corporate governance. Journal of Finance, v. 43, p. 567-591, 1988. 1996.

WILLIAMSON, O. The mechanisms of governance. Oxford University Press,

WILLIAMSON, O. Transaction Cost Economics and Organization Theory. Journal of Industrial and Corporate Change, v. 2, p. 107-156, 1993.

WIMMER, B. S.; GAREN, J. E. Moral hazard, asset specificity, implicit bonding, and compensation: the case of franchising. Economic Inquiry, v. 35, n. 3, p. 544-554, 1997.

WINTER, S. G.; SZULANSKI, G. Replication as Strategy. Journal of Product Innovation Management, v. 12, n. 5, 1995.

WOOLDRIDGE, J. Introdução à Econometria: uma abordagem moderna. São Paulo: Thomson, 2006.

WRIGHT, O.; MCAULEY, A. Australian franchising research: Review, synthesis and future research directions. Australasian Marketing Journal, v. 20, p. 158-163, 2012. 
YIN, X.; ZAJAC, E. J. The strategy/governance structure fit relationship: Theory and evidence in franchising arrangements. Strategic Management Journal, n. 11, p. 365-383, 2004.

YVRANDE-BILLON, A.; SAUSSIER, S. Do organization choices matter? Assessing the importance of governance through performance comparisons. Em New ideas in contracting and organizational economics research. Nova Science Publishers, p. 69-86, 2004. 